MARCELO ROCHA

\title{
ANOTAÇÕES SOBRE O GESTOR JUDICIAL NA RECUPERAÇÃO DE EMPRESAS
}

\author{
Dissertação de Mestrado
}

Orientador: Professor Mauro Rodrigues Penteado.

FACULDADE DE DIREITO DA UNIVERSIDADE DE SÃO PAULO

São Paulo

2014 
MARCELO ROCHA

\section{ANOTAÇÕES SOBRE O GESTOR JUDICIAL NA RECUPERAÇÃO DE EMPRESAS}

Dissertação apresentada à Banca Examinadora da Faculdade de Direito da Universidade de São Paulo, como exigência parcial para a obtenção do título de Mestre em Direito Comercial, sob orientação do Professor Associado Mauro Rodrigues Penteado.

FACULDADE DE DIREITO DA UNIVERSIDADE DE SÃO PAULO São Paulo 


\section{FOLHA DE APROVAÇÃO}

Nome: ROCHA, Marcelo

Título: Anotações sobre o Gestor Judicial na recuperação de empresas

Dissertação apresentada à Faculdade de Direito da Universidade de São Paulo como requisito parcial para a obtenção do título de Mestre em Direito Comercial

Data de Defesa:

Resultado:

Banca Examinadora:

Prof. Associado Mauro Rodrigues Penteado Universidade de São Paulo

Prof. Dr.(a)

Universidade de São Paulo

Prof. Dr.(a)

Universidade 


\section{AGRADECIMENTOS}

A Deus, a quem tudo devo.

À minha esposa Cláudia e aos nossos filhos Laura e Pedro, pelo apoio, compreensão e carinho.

Aos meus pais Adhemar e Maria, pelo exemplo.

Agradeço, em especial, ao meu orientador, Professor Associado Mauro Rodrigues Penteado, pela oportunidade que me foi concedida, bem como pela atenção, apoio, correções e valiosas sugestões dispensados durante todo o mestrado.

Agradeço, por fim, aos amigos da Lazzareschi, Hilal, Bolina \& Rocha Advogados, pelos enriquecedores debates, e às bibliotecárias Andréia Gonçalves Silva e Nicélia Vicente, pela colaboração na obtenção dos livros e artigos consultados e pela revisão das referências bibliográficas. 


\section{RESUMO}

Esta dissertação tem por objeto examinar as questões jurídicas relativas aos efeitos da recuperação judicial na gestão da atividade empresarial do devedor, especificamente quanto às hipóteses de nomeação e as funções do gestor judicial. Isto porque, apesar de a recuperação não ter como consequência direta o afastamento dos administradores e/ou do devedor, eles poderão vir a ser destituídos na hipótese de ocorrência de uma das circunstâncias taxativamente descritas nos incisos do art. 64 da LREF. Neste caso, se se tratar dos administradores, eles serão substituídos por novos, eleitos pelos sócios, obedecendo-se às regras fixadas no contrato (ou estatuto) social. Na hipótese, contudo, de afastamento do devedor, o art. 65 da LREF apenas dispõe que os credores elegerão o gestor judicial "que assumirá a administração das atividades do devedor", sem estabelecer, com precisão, qual o preciso sentido do termo "devedor", cuja melhor interpretação parece ser a própria sociedade empresária devedora. Em consequência, se se verificar a ocorrência de uma das circunstâncias descritas na LREF, afastada será a própria sociedade empresária devedora, na qual hipótese o gestor judicial, eleito pelos credores e nomeado pelo juiz, assumirá a gestão da atividade da empresa em dificuldade econômico-financeira, sem ingressar no quadro social. O gestor judicial não assume, entretanto, a condução do processo de recuperação judicial, nem a apresentação e a aprovação de eventuais alterações no plano de recuperação, funções essas que serão exercidas pela própria sociedade empresária devedora, devidamente presentada por seus órgãos de administração. Ao gestor judicial, por outro lado, são impostos os mesmos deveres exigidos do administrador de toda e qualquer sociedade, a saber, dever de diligência (praticar os atos de gestão segundo as modernas técnicas de administração de empresa), dever de lealdade (para com a requerente da recuperação judicial, e não para com os credores que elegeram o gestor judicial) e dever de obediência à lei. Violado qualquer um desses deveres, o gestor judicial responderá pessoalmente pelas obrigações assumidas. Caso contrário, se os deveres forem cumpridos, o gestor judicial não responderá pessoalmente pelos atos praticados na condução dos negócios, ainda que a devedora venha a ter sua recuperação judicial convolada em falência.

Palavras-chave: Recuperação Judicial; Sociedade Empresária; Gestor Judicial. 


\begin{abstract}
The purpose of this essay is to analyze legal issues related to the effects of reorganization over management activity. Notwithstanding such reorganization does not result directly in taking managers and/or debtor off, they may be removed in the event of any of the circumstances clearly described in subsections of section 64 of LREF [Brazilian Law for Companies' Reorganization and Bankruptcy] takes place. In this case, if taking into account the managers, they shall be replaced by new ones, elected by the partners, subject to rules set forth in Articles of Association (or By-laws). In the event, however, of removal of debtor, section 65 of LREF provides for only that the creditors shall elect a trustee, who shall take the management of activities of the debtor, without accurately providing for the exact meaning of the word "debtor". The interpretation of the word "debtor" seems to be the debtor business company itself. As a consequence, if it is verified the occurrence of one of the circumstances set forth in LREF, the debtor business company itself shall be removed, event in which the trustee, elected by the creditors and appointed by judge, shall take the management of the activity of the company in financial and economic crisis, without taking part in ownership structure. Trustee will not direct, however, the conduction of courtsupervised reorganization proceeding, or the presentation and approval of eventual changes in reorganization plan, which duties shall be exercised by the debtor business company itself, duly represented by its managing boards. The same duties required from the manager of any and all company are imposed to the trustee: diligence, loyalty and duty of compliance with the law. If any of such duties are infringed, the trustee shall be personally liable for obligations taken. Otherwise, if the duties are accomplished, the trustee will not be personally liable for the acts performed while directing business, even if the debt has its reorganization converted into bankruptcy.
\end{abstract}

Keywords: Reorganization; Business Company; Trustee. 


\section{SUMÁRIO}

1. Evolução histórica da administração do devedor na legislação falimentar brasileira

1.1. O Código Comercial de 1850 .................................................................. 18

1.2. O Decreto $\mathrm{n}^{\mathrm{o}}$ 917, de 24.10.1890 ............................................................ 19

1.3. $\quad$ A Lei $n^{\circ} 859$, de 16.8.1902 ...................................................................... 21

1.4. $\quad$ A Lei $n^{\mathrm{o}} 2.024$, de 17.12.1908 ................................................................... 24

1.5. O Decreto $n^{0}$ 5.746, de 9.12.1929 …....................................................... 27

1.6. O Decreto-Lei $\mathrm{n}^{\mathrm{o}} 7.661$, de 21.06.1945 ................................................ 30

CAPÍTULO II - ANOTAÇÕES À ADMINISTRAÇÃO DO DEVEDOR NA LEGISLAÇÃO FALIMENTAR ESTRANGEIRA

1. Alemanha 39

2. Portugal

3. Espanha . 51

4. Argentina 56

5. França 62

6. Itália 69

7. Estados Unidos 73

CAPÍTULO III - A NOMEAÇÃO DO GESTOR JUDICIAL É EXCEÇÃO À REGRA GERAL DE MANUTENÇÃO DO DEVEDOR

1. A manutenção do administrador e do devedor na gestão da empresa em recuperação judicial

2. Introdução ao conceito de devedor na LREF

3. O controlador

3.1. Formas de controle 
3.2. Abuso do poder de controle ..................................................................... 104

4. A administração das sociedades empresárias ............................................ 106

4.1. A administração da sociedade limitada .................................................... 106

4.2. A administração da sociedade por ações .................................................. 111

5. Retomando o conceito de devedor na LREF ............................................ 113

6. A recuperação judicial de VARIG - Viação Aérea Rio-Grandense S.A., Rio Sul Linhas Aéreas S.A. e Nordeste Linhas Aéreas S.A.

\section{CAPÍTULO IV - OS PRESSUPOSTOS E O PROCEDIMENTO PARA A NOMEAÇÃO DO GESTOR JUDICIAL}

1. A condenação penal transitada em julgado

2. Os indícios da prática de crime falimentar

3. O dolo, a simulação ou a fraude contra os interesses dos credores

4. Os gastos pessoais excessivos

5. As despesas injustificáveis

6. A descapitalização injustificada da empresa devedora

7. A simulação e a omissão de crédito

8. O descumprimento da obrigação de prestar informações

9. O afastamento do administrador e do devedor previsto no plano de recuperação judicial

9.1. Substituição total ou parcial dos administradores do devedor ou modificação de seus órgãos administrativos

9.2. Concessão aos credores de direito de eleição em separado de administradores e de poder de veto em relação às matérias que o plano especificar

9.2.1. A concessão aos credores de direito de eleição em separado de administradores na sociedade limitada

9.2.2. A concessão aos credores de direito de eleição em separado de administradores na sociedade por ações

9.3. A concessão aos credores de poder de veto em relação às matérias especificadas no plano de recuperação judicial

9.4. Administração compartilhada 
9.5. O afastamento do devedor previsto no plano de recuperação

9.5.1 A recuperação judicial de Bombril Holding S.A. ..................................... 155

10. O procedimento para o afastamento do devedor ....................................... 157

11. O procedimento para a eleição do gestor judicial: a assembleia geral de credores e a nomeação pelo juiz

12. O perfil do gestor judicial

CAPÍTULO V - O EXERCÍCIO DA FUNÇÃO DO GESTOR JUDICIAL: SEUS DEVERES, RESPONSABILIDADES E REMUNERAÇÃO

1. As funções do gestor judicial

2. O exercício provisório das funções do gestor judicial: o administrador judicial

3. Os deveres e a responsabilidade do gestor judicial

3.1. O dever de diligência

3.2 O dever de lealdade

3.3. O dever de obediência

3.4. Retomando: os deveres e a responsabilidade do gestor judicial

4. A remuneração do gestor judicial

5. A responsabilidade dos credores pela eleição do gestor judicial 
CAPÍTULO I - INTRODUÇÃO 


\section{CAPÍTULO I - INTRODUÇÃO}

A Lei n ${ }^{\circ}$ 11.101, de 9.2.2005 (conhecida como Lei de Recuperação de Empresas e Falências - LREF), promulgada após tramitação por mais de dez anos no Congresso Nacional (MORI, 2005, p. 27), dispõe, em seu art. $1^{\circ}$, que seu objeto é disciplinar "a recuperação judicial, a recuperação extrajudicial e a falência do empresário e da sociedade empresária, doravante referidos simplesmente como devedor."

$\mathrm{O}$ art. $2^{\circ}$, por sua vez, acrescenta que não são objeto da LREF as empresas públicas, as sociedades de economia mista, as instituições financeiras públicas ou privadas, as cooperativas de crédito, os consórcios, as entidades de previdência complementar, as sociedades operadoras de plano de assistência à saúde, as sociedades seguradoras e "outras entidades legalmente equiparadas às anteriores".

Da conjugação dessas duas normas da Lei $n^{\circ} 11.101 / 2005$ decorre que, com exceção das entidades expressamente referidas nos incisos do art. $2^{\circ}$, para os efeitos da LREF entende-se por devedor ${ }^{1}$ - e consequentemente sujeito à recuperação judicial, à recuperação extrajudicial e à falência - tanto o empresário individual quanto a sociedade empresária.

O empresário individual a que se refere o artigo $1^{\circ}$ da LREF é a pessoa natural que preencha os requisitos dos arts. 966 e 967 do Código Civil, ou seja, a pessoa física que, cumulativamente, (a) "exerce profissionalmente atividade econômica organizada para a produção ou circulação de bens ou de serviços", (b) esteja regularmente inscrita como empresário no Registro Público de Empresas Mercantis, e (c) não exerça “profissão intelectual, de natureza científica, literária ou artística, ainda com o concurso de auxiliares ou colaboradores, salvo se o exercício da profissão constituir elemento de empresa."

A sociedade empresária que integra a definição de "devedor" do art. $1^{\circ}$ da LREF, por sua vez, é aquela que, com exceção das entidades discriminadas no art. $2^{\circ}$ da mesma lei, (i) constituiu-se sob a forma de sociedade por ações nos termos da Lei $n^{\circ}$

\footnotetext{
${ }^{1} \mathrm{O}$ conceito de “devedor” será reexaminado no capítulo III da dissertação.
} 
6.404/1976 (art. 982 do Código Civil, parágrafo único)², ou (ii) que "tem por objeto o exercício de atividade própria de empresário sujeito a registro (art. 967)” (art. 982 do Código Civil) $)^{3}$, com exceção da cooperativa (art. 982 do Código Civil, parágrafo único).

Desse modo, considera-se empresária a sociedade por ações, qualquer que seja seu objeto social, e a sociedade que exerce atividade econômica organizada para a produção ou circulação de bens ou de serviços. Neste último caso, dispõe o art. 983 do Código Civil, "a sociedade empresária deve constituir-se segundo um dos tipos regulados nos arts. 1.039 a 1.092" do próprio Código Civil, ou seja, ela poderá se constituir sob a forma de sociedade em nome coletivo (art. 1.039 a 1.044 do Código Civil), sociedade em comandita simples (art. 1.045 a 1.051 do Código Civil), sociedade limitada (art. 1.052 a 1.087 do Código Civil) e a sociedade em comandita por ações (art. 1.090 a 1.092 do Código Civil).

Qualquer que seja o tipo societário escolhido (em nome coletivo, em comandita simples, limitada, por ações e em comandita por ações), desde que seja empresária, a sociedade está subordinada à LREF e, consequentemente, poderá se valer da recuperação judicial e da recuperação extrajudicial para se soerguer na hipótese de eventual crise econômico-financeira, mas estará sujeita à falência.

Acrescente-se que embora o art. $1^{\circ}$ da LREF faça expressa referência apenas ao empresário e à sociedade empresária, também está sujeita à recuperação (judicial e extrajudicial) e à falência a empresa individual de responsabilidade limitada, conhecida por EIRELI, introduzida no ordenamento jurídico nacional pela Lei $\mathrm{n}^{\circ} 12.441$, de 11 de julho de 2011, que entrou em vigor no dia 10 de janeiro de $2012^{4}$.

\footnotetext{
2 “Art. 982. (...) Parágrafo único. Independentemente de seu objeto, considera-se empresária a sociedade por ações; e, simples, a cooperativa".

3 “Art. 982. Salvo as exceções expressas, considera-se empresária a sociedade que tem por objeto o exercício de atividade própria de empresário sujeito a registro (art. 967); e simples, as demais”.

${ }^{4}$ Em obra específica a respeito da empresa individual de responsabilidade limitada, ABRÃO (2012, p. 80) destaca que "ambientando permitir a preservação do negócio, do emprego, e atender a função social da empresa, a Lei $n^{\circ}$ 11.101/2005 edificou caminho sólido e muito propício para defendermos a tese da reorganização societária. No entanto, de maneira franciscana e muito tímida, coube ao legislador distinguir empresas maiores daquelas menores e, a partir daí, conferir, no art. 70, e seguintes, o procedimento de recuperação de empresas de menor porte. A questão que se coloca é no sentido de se saber se o empresário individual poderia, diante dos problemas do próprio negócio, valer-se da recuperação judicial ou daquela de natureza extrajudicial e, portanto, contratual. Dotado de personalidade jurídica e regularmente constituído, obedecido capital não inferior a 100 salários-mínimos, em tese, haveria perspectiva de se socorrer da recuperação judicial, porém, com certas limitações e algumas imperfeições."
} 
Sujeitos passivos da LREF, assim, são o empresário individual, a sociedade por ações (que sempre é empresária), a sociedade empresária em nome coletivo, a sociedade empresária em comandita simples, a sociedade empresária limitada, a sociedade empresária em comandita por ações e a empresa individual de responsabilidade limitada.

Como, porém, os empresários individuais não exploram atividades econômicas relevantes $^{5}$ (COELHO, 2008, p. 18), e as sociedades empresárias em nome coletivo, em comandita simples e em comandita por ações não são muito utilizados atualmente ${ }^{6}$, nesta dissertação o exame do gestor judicial (fundamentalmente quanto às hipóteses de sua nomeação, funções, deveres, responsabilidades e remuneração) não terá por objeto as hipóteses nas quais a recuperação judicial tem por devedor um desses sujeitos passivos.

De igual modo, não se analisará nesta dissertação a recuperação judicial requerida por empresa limitada de responsabilidade limitada, pois apesar de sua recente introdução no sistema jurídico justificar o exame do cabimento ou não da nomeação de gestor judicial nesse processo de recuperação judicial, ABRÃO (2012, p. 81) assinala que

o empresário individual, sujeitando-se à recuperação, veria, em primeiro lugar, que apenas os credores quirografários ficariam subordinados ao processamento e deferimento do pedido, cujo prazo de cumprimento seria de três anos e o juros de $12 \%$ ao ano. A ferramenta judicial não é verda-

\footnotetext{
5 Além de não exercerem atividades econômicas relevantes, AYOUB e CAVALLI (2013, p. 26) destacam que "a qualificação de empresário decorrente da caracterização do elemento de empresa é fonte de grande insegurança jurídica, pois é um critério ex post de qualificação de empresário. Assim, se um dentista exerce sua profissão, ele se registrará no Conselho de Odontologia e se submeterá ao estatuto profissional próprio. No entanto, se ele organizar uma grande quantidade de fatores de produção - quantidade esta que a lei não declinou em seu texto -, ele será qualificado como empresário e se sujeitará ao estatuto do empresário. Com efeito, uma vez qualificado como empresário, sua falência poderá ser decretada e, decretada sua falência, deverá o profissional apresentar sua escrituração regularmente lavrada, o que envolve a autenticação de seus livros na Junta Comercial. Como o malfadado dentista jamais pensou que fosse empresário, seus livros não estão autenticados na Junta Comercial, o que abre as portas para a caracterização de crime falimentar. Pelas consequências da caracterização ex post do empresário, já se vê o quão pernicioso é o critério do elemento de empresa (...) No que respeita à recuperação judicial de empresas, o sujeito qualificado como empresário em razão da caracterização de elemento de empresa não se legitimará a postulá-la, não por não ser qualificado como empresário, mas por lhe faltarem os demais requisitos de legitimação à postulação da recuperação judicial, como ocorre, por exemplo, com os produtores rurais."

${ }^{6}$ Segundo informação constante no sítio mantido na internet pelo Departamento Nacional de Registro do Comércio (www.dnrc.gov.br), consultado em 10.07.2013, no período compreendido entre os anos de 1985 e 2005 foram constituídas 8.915.890 empresas, sendo 4.569.288 "firmas" individuais (o que corresponde a $51,25 \%$ ), 4.300.257 sociedades limitadas (ou 48,23\% do total), 20.080 sociedades por ações (equivalente a $0,23 \%$ ) e 21.731 cooperativas (correspondente a $0,24 \%$ ), sendo que as 4.534 empresas remanescentes (ou $0,05 \%$ do total) adotaram os demais tipos societários.
} 
deiro estímulo para que o empresário individual tome a iniciativa da recuperação, mais ainda quando enfrenta os custos do processo e a eternização do feito, com a sequência de recursos e a inerente possibilidade de quebra.

Em outras palavras, como esclarece PENTEADO (2007, p. 58), a nova legislação "situa-se distante do Brasil real", pois com exceção do regime especial facultado às microempresas e empresas de pequeno porte (arts. 70 a 72 da LREF), estabeleceu regime único "extremamente sofisticado (...) cuja operacionalização será extremamente dificultosa", pois não se pode esperar que em um país onde apenas $0,23 \%$ das empresas têm seu capital dividido em ações, "saiba ou tenha experiência em lidar com Assembleias-Gerais, ou como regime dualista de administração, neste figurando órgão colegiado facultativo (o Comitê de Credores), e também um órgão executivo, profissionalizado (art. 21).”

Daí que, em virtude da relevância para a economia brasileiras, as sociedades empresariais limitadas e as sociedades por ações é que se valem, com maior frequência, da recuperação (judicial e extrajudicial), motivo pelo qual o objeto desta dissertação limita-se ao exame das hipóteses de nomeação, as funções, os deveres, as responsabilidades e a remuneração do gestor judicial nos casos em que o devedor é pessoa jurídica constituída sob a forma limitada e por ações.

Independentemente, porém, de tratar-se de empresário individual, de sociedade empresária ou de empresa limitada de responsabilidade limitada, o pedido de recuperação judicial, e sua concessão, não importam no afastamento do devedor nem na destituição de seus administradores, os quais permanecem na condução da atividade empresarial, como expressamente dispõe a parte inicial do art. 64 da LREF: "durante o procedimento de recuperação judicial, o devedor ou seus administradores serão mantidos na condução da atividade empresarial, sob fiscalização do Comitê, se houver, e do administrador judicial.”

Discorrendo a respeito dos efeitos da recuperação judicial, VERÇOSA (2006 ${ }^{\mathrm{a}}$, p. 30) destaca a ocorrência de algumas modificações estruturais na sociedade devedora, destacando-se:

(a) o controlador permanece com a titularidade das ações ou quotas que lhe outorgam o status correspondente, mas agora sujeito a um novo regime de atuação; (b) permanecem em funcionamento os órgãos normais da 
sociedade até então existentes (Conselho de Administração - se for o caso -, Diretoria, Conselho Fiscal e conselhos estatutários); (c) são instituídos dois novos órgãos obrigatórios que funcionarão durante todo o processo de recuperação judicial, quais sejam o Administrador Judicial e a Assembleia de Credores ${ }^{7}$ (arts. 21 e 35); (d) são eventualmente instituídos dois novos órgãos não obrigatórios para o mesmo período, o Comitê de Credores e o Gestor Judicial (arts. 26, 64 e 65).

Mas embora "os órgãos normais" permaneçam em funcionamento, a parte final do referido art. 64 da LREF estabelece hipóteses nas quais o administrador do devedor, eleito pelos sócios nos termos fixados no contrato ou no estatuto social, é afastado da condução da atividade empresarial, casos em que "será substituído na forma prevista nos atos constitutivos do devedor ou do plano de recuperação judicial”.

E o art. 65 da LREF, por sua vez, dispõe que, "quando do afastamento de devedor, nas hipóteses previstas no art. 64 desta Lei, o juiz convocará a Assembleia-Geral de Credores para deliberar sobre o nome do gestor judicial que assumirá a administração das atividades do devedor, aplicando-se-lhe, no que couber, todas as normas sobre deveres, impedimentos e remuneração do administrador judicial."

Desses dispositivos da LREF decorre que, verificada a ocorrência de uma das situações previstas nos incisos do art. 64, a consequência é o afastamento do devedor ou seus administradores, não a decretação da falência, pois se "a recuperação judicial tem por objetivo viabilizar a superação da situação de crise econômico-financeira do devedor, a fim de permitir a manutenção da fonte produtora, do emprego dos trabalhadores e dos interesses dos credores, promovendo, assim, a preservação da empresa, sua função social e o estímulo à atividade econômica" (art. 47, LREF), efetivamente não há razão para decretar-se a falência de um devedor em crise, mas economicamente viável, apenas porque seus sócios ou administradores efetuaram "gastos pessoais manifestamente excessivos em relação à sua situação patrimonial” (art. 64, IV, “a”, LREF).

Daí que a LREF separou a sorte da empresa da do empresário ou seus administradores: enquanto na revogada Lei de Falências (Decreto-lei no 7.661, de 21.06.1945), por

\footnotetext{
${ }^{7}$ De modo diverso FRANÇA (2007, p. 189) afirma que a assembleia geral é um órgão de funcionamento facultativo, porque na recuperação judicial, se nenhum credor se opuser ao plano apresentado pelo devedor, é possível que a assembleia geral de credores jamais seja convocada.
} 
exemplo, a condenação de um único administrador pela prática de crime falimentar importava na convolação da concordata preventiva em falência (art. 150, inc. VII) e impedia a concessão de concordata suspensiva (art. 111), ainda que a empresa fosse economicamente viável, na LREF se houver indícios veementes da prática de crime falimentar, o administrador ou o devedor será destituído e substituído, respectivamente, na forma ajustada no contrato ou estatuto social (art. 64, inc. I e parágrafo único), ou pelo gestor judicial (art. 65), não se convolando a recuperação judicial em falência.

A Lei no 11.101, de 9.2.2005, assim, contém dispositivos cuja incidência pode importar em alterações na condução da atividade empresarial, tais como (a) a destituição dos administradores e sua substituição por outros nomeados na forma prevista nos atos constitutivos da sociedade ou no plano de recuperação judicial (art. 64, parágrafo único), ou (b) no afastamento do devedor e consequente nomeação de gestor judicial, eleito em assembleia geral de credores (art. 65).

Dessas normas decorrem questões jurídicas que serão examinadas nesta dissertação, sem a pretensão de apresentar respostas definitivas, mas apenas fomentar o debate acadêmico, contribuindo para o estudo dos direitos societário e falimentar.

Para tanto, a título introdutório (Capítulo I) faz-se necessário expor aspectos gerais da evolução histórica da legislação falimentar no Brasil, especificamente em relação à administração do devedor.

O Capítulo II do trabalho, por sua vez, abordará notas introdutórias à administração do devedor na legislação falimentar estrangeira, de modo a examinar, ainda que superficialmente, seu tratamento em sistemas jurídicos do common law e de legislações de tradição romano-germânica.

Em seguida, o Capítulo III do trabalho versará considerações gerais a respeito da administração do devedor na LREF, onde se examinará que a nomeação do gestor judicial em substituição ao devedor é exceção, pois, como é da tradição do direito positivo brasileiro, o devedor e seus administradores são, em regra, mantidos na condução da atividade empresarial. 
Já no Capítulo IV, a dissertação abordará os pressupostos e os procedimentos para a nomeação do gestor judicial, ou seja, serão examinadas as hipóteses de destituição do administrador e de afastamento do devedor, bem como os procedimentos para a eleição do gestor judicial pelos credores reunidos em assembleia geral e a subsequente nomeação pelo juiz.

O Capítulo V, por seu turno, examinará as funções exercidas pelo gestor judicial, analisando as hipóteses de sua substituição provisória pelo administrador judicial, bem como seus deveres, responsabilidades e remuneração. Neste capítulo também se referirá a responsabilidade dos credores na hipótese de eleição do gestor judicial.

Acrescente-se, por fim, que tanto o título da dissertação quanto a ordem de exposição e o alcance do objeto do estudo foram definidos em função das observações, considerações, sugestões e contribuições recebidas dos membros que integraram a banca de qualificação que examinou o projeto de dissertação ${ }^{8}$.

\section{Evolução histórica da administração do devedor na legislação falimentar brasileira}

Após a independência do Brasil, por força da Lei de 20 de outubro de 1823, a legislação de Portugal continuou tendo eficácia no Brasil, até que novas leis viessem a ser editadas ${ }^{9}$, anotando REQUIÃO $(1975$, p. 18) que

essa lei mandou observar a Lei da Boa Razão, isto é, o Alvará de 18 de agosto de 1769 , segundo o qual deviam ser aplicadas subsidiariamente as leis das nações civilizadas. Deu-se, por isso, larga preferência à aplicação do Código Comercial napoleônico, de 1807. Disso decorreu a profunda influência do direito francês na evolução do nosso direito, inclusive em matéria falimentar.

\footnotetext{
8 A banca de qualificação foi constituída pelos ilustres Professores Mauro Rodrigues Penteado, Eduardo Secchi Munhoz e Rodrigo Octávio Broglia Mendes, a quem se rendem sinceras homenagens e agradecimentos.

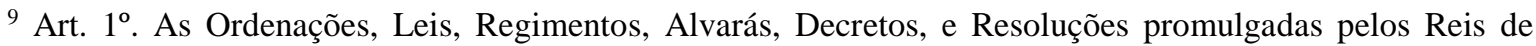
Portugal, e pelas quaes o Brazil se governava até o dia 25 de Abril de 1821, em que Sua Magestade Fidelissima, actual Rei de Portugal, e Algarves, se ausentou desta Côrte; e todas as que foram promulgadas daquella data em diante pelo Senhor D. Pedro de Alcantara, como Regente do Brazil, em quanto Reino, e como Imperador Constitucional delle, desde que se erigiu em Imperio, ficam em inteiro vigor na parte, em que não tiverem sido revogadas, para por ellas se regularem os negocios do interior deste Imperio, emquanto se não organizar um novo Codigo, ou não forem especialmente alterada.
} 


\subsection{O Código Comercial de $\mathbf{1 8 5 0}$}

A deficiência na legislação e a facilidade das quebras, porém, contribuíram para a edição do Código Comercial de 1850 (MENDONÇA, 1916, p. 59), que regulou o processo falimentar em sua terceira parte (arts. 797 a 906), onde não se previu qualquer procedimento que pudesse ser empregado para evitar a decretação de falência do devedor que, no exercício regular de sua atividade, viesse a enfrentar dificuldades financeiras.

O Código Comercial estabeleceu apenas a possibilidade de o devedor obter moratória, por prazo não superior a três anos (art. 901), caso comprovasse, nos termos do artigo 898, "que a sua impossibilidade de satisfazer de pronto as obrigações contraídas procede de acidentes extraordinários imprevistos, ou de força maior (art. 799)", moratória essa cujo efeito era "suspender toda e qualquer execução, e sustar a obrigação do pagamento das dívidas puramente pessoais do indiciado: mas a moratória não suspende o andamento ordinário dos litígios intentados ou que de novo se intentem; salvo quanto à sua execução" (art. 903).

Estabeleceu ainda o Código Comercial que a falência decretada poderia ser suspensa por concordata, cuja concessão dependia da apresentação de projeto pelo falido, sua aprovação pelos credores em reunião e homologação judicial (arts. 842, 846 e 850).

Daí que, no regime do Código Comercial, o devedor poderia valer-se da moratória apenas se a impossibilidade de cumprir suas obrigações decorresse de acidentes extraordinários ou de força maior, bem como poderia obter a suspensão da falência se, após a instrução do processo falimentar, apresentasse projeto de concordata e esse projeto fosse aprovado pelos credores e homologado pelo juiz.

Salienta NEGRÃO (2010, p. 23), ainda, que

em 6 de maio de 1882 é promulgado o Decreto n. 3.065, que acrescentou aos meios recuperatórios a concordata por abandono. Consistia o novo instituto na cessão de todo ou de parte do ativo do falido a favor dos credores. Essa modalidade de origem francesa (lei de 17 de junho de 1856) surgiu, no direito pátrio, no projeto de reforma da Parte Terceira do Código Comercial, da lavra do então Ministro da Justiça Joaquim Nabuco e 
que foi apresentado em $1^{\circ}$ de julho de 1866, na Câmara dos Deputados. Com apenas seis artigos, o novo diploma legal alterou as condições para a concessão da concordata, reduzindo o quorum de instalação para a maioria que representasse dois terços de todos os créditos e o quorum de deliberação para maioria desses credores (art. $1^{\circ}$ do decreto n. 3.065 , de 1882).

Nestes dois casos (moratória e concordata suspensiva) o devedor continuava sendo administrado pelas pessoas indicadas em seus atos sociais, tanto que o art. 826 do Código Comercial dispunha que o falido ficava proibido de administrar e dispor de seus bens, acrescentando o art. 854, porém, que, concedida a concordata, todos os bens arrecadados deveriam ser restituídos ao devedor. Isso não obstante, nas duas hipóteses o devedor não podia "atear, nem gravar de maneira alguma seus bens de raiz, móveis ou semoventes, sem assistência ou autorização dos credores fiscais" (art. 904), sob pena de revogação da moratória (com a consequente declaração da falência - art. 902) ou rescisão da concordata (art. 849).

\subsection{O Decreto $\mathrm{n}^{0}$ 917, de 24.10 .1890}

Após a Proclamação da República, o Governo Provisório da República dos Estados Unidos do Brazil editou o Decreto ${ }^{\circ}$ 917, de 24.10.1890, que revogou integralmente a Parte III do Código Comercial de 1850, que regulava o processo falimentar. Esta nova legislação estabeleceu, como meios de o devedor em dificuldade financeira evitar a decretação de sua falência, a moratória, o acordo com credores (ou concordata extrajudicial) e a cessão de bens ${ }^{10}$.

No regime do Decreto $n^{\circ}$ 917/1890, o devedor poderia requerer ao juiz a concessão de moratória, por prazo não superior a um ano (art. 112) ${ }^{11}$, apenas se comprovasse que a impossibilidade de cumprimento de suas obrigações decorria de acidentes extraordinários, imprevistos ou força maior, e que seu patrimônio era suficiente para pagar todos os

\footnotetext{
${ }^{10}$ Art. 12. Não será declarada a fallencia, mas ficará suspensa, definitiva ou provisoriamente, si o commerciante, sua viúva ou seus herdeiros: a) antes do protesto por falta de pagamento de alguma obrigação mercantil requerer moratória; b) tiver feito com os credores algum accordo ou concordata extrajudicial pela forma indicada neste decreto; c) dentro de dois dias depois da interposição do protesto, requerer a convocação dos credores para fazer-lhes cessão de bens, pela forma indicada neste decreto.

${ }^{11}$ A moratória podia ser prorrogada uma única vez, por prazo não superior a um ano, desde que o devedor houvesse pago, no período original da moratória, ao menos $50 \%$ do valor principal dos débitos a ela sujeitos (art. 119).
} 
seus débitos, inclusive os juros, desde que lhe fosse concedida dilação do prazo originalmente contratado (art. 107) ${ }^{12}$.

A concordata extrajudicial, por sua vez, consistia em acordo celebrado entre o devedor e credores representando ao menos 3/4 (três quartos) do passivo, acordo esse que, homologado judicialmente, obrigava todos os credores quirografários e obstava a declaração da falência, exceto (a) por dívidas posteriores à concordata ou (b) se o devedor descumprisse o acordo (arts. $120^{13}$ e $128^{14}$ ).

A cessão de bens, por fim, era o modo de evitar a declaração da falência por meio da qual o devedor, no prazo de até 48 horas após seu primeiro protesto, requeria judicialmente a dação da totalidade de seus bens aos credores, exonerando-o de quaisquer responsabilidades (art. 131). Embora evitasse a decretação da falência, como o patrimônio do devedor era integralmente empregado para pagar as dívidas e o eventual saldo era transferido aos credores (art. $137, \S 2^{\circ}$ ), a cessão dos bens não possibilitava a superação da crise econômico-financeira do devedor. Tratava-se, assim, apenas de meio de liquidação do passivo.

Daí que, apenas a moratória e a concordata extrajudicial permitiam o soerguimento do devedor em crise. E, para tanto, nestes dois casos seus administradores eram mantidos no exercício de seus cargos, mas a prática de certos atos dependia de autorização

\footnotetext{
${ }^{12}$ Art. 107. O commerciante, cuja firma estiver inscripta no registro, antes de protesto por falta de pagamento de alguma obrigação mercantil liquida e certa e em condições de autorizar a declaração de fallencia, provando que está na impossibilidade de satisfazer de prompto suas obrigações por accidentes extraordinarios, imprevistos ou de força maior e que não se acha em estado de insolvencia, tendo fundos bastantes para pagar a todos os credores de principal e juros mediante alguma espera, poderá requerer ao juiz commercial, com jurisdicção na séde do seu principal estabelecimento, a concessão de moratoria.

13 Art. 120. O devedor, com firma inscripta no registro do commercio, que antes de protesto por falta de pagamento de obrigação commercial liquida e certa, tiver feito extrajudicialmente algum accordo ou concordata com os credores representando pelo menos $3 / 4$ da totalidade do passivo, deverá requerer sem demora a homologação pelo juiz commercial com jurisdição na séde de seu principal estabelecimento e, obtida ella, não poderá ser declarado fallido.

${ }^{14}$ Art. 128. A homologação da concordata produzirá o effeito de obrigar a todos os credores chirographarios, e obstará á declaração de fallencia, salvo por falta de pagamento de divida contrahida depois della, ou si não for cumprido o accordo.
} 
da comissão fiscal, no caso da moratória ${ }^{15}$, ou do juiz, se se tratasse de acordo com os credores ${ }^{16}$.

Acrescente-se ainda que a falência decretada poderia ser suspensa por concordata (a) por abandono, consistente "na adjudicação de todos os bens presentes da massa ou de parte delles aos credores para solução do passivo e importará completa desoneração do devedor, que ficará livre dos effeitos commerciaes, civis e criminaes da fallencia" (art. 43), ou (b) por pagamento, hipótese na qual o devedor era mantido na posse da massa pelo tempo acordado para o pagamento do passivo (art. 44), sendo que durante este período, para efeito de apuração de sua responsabilidade no caso de descumprimento da concordata, o falido era "considerado depositário dos bens da massa, com poderes de disposição e administração" (art. 44, § $2^{\circ}$ ).

\subsection{A Lei no 859 , de 16.8.1902}

O Decreto $n^{\circ} 917$, de 24.10.1890, foi revogado pela Lei $\mathrm{n}^{\circ} 859$, de 16.8.1902, publicada na edição do Diário Oficial de 22.8.1902, nova legislação essa que sofreu muitas críticas, em especial quanto à exigência (art. $16^{17}$ ) de o síndico ser nomeado pelo juiz a

15 Art. 117. O devedor que obtiver moratoria não poderá alhear bens immoveis, hypothecal-os ou dal-os em antichrese, nem garantir dividas com penhores ou caução sem autorização da commissão fiscal, com recurso por petição para o juiz.

${ }^{16}$ Art. 129. Durante o processo da homologação, não poderá o devedor alienar ou hypothecar seus bens, nem contrahir novas obrigações sem autorização do juiz, que procederá ás informações necessarias.

17 Art. 16. O juiz nomeará, além do syndico provisorio, uma commissão fiscal composta de dous credores, tirados aquelle e esta de duas listas organisadas na fórma em seguida declarada: $\S 1^{\circ}$ De dous em dous annos, no mez de dezembro, as Juntas Commerciaes, onde as houver, organisarão uma lista de commerciantes do logar, e a remetterão ao juiz do commercio, para servirem os alistados como syndicos nas fallencias que occurrerem nos dous annos seguintes: a) nos logares onde não houver Junta Commercial será a lista formada pelos commerciantes maiores contribuintes, em numero, pelo menos, de dez, convocados pelo juiz á vista da certidão da repartição fiscal federal para, em dia e logar determinados, se reunirem para este fim, sob sua presidencia; b) o numero dos nomes da lista será: de 40 na Capital Federal; de 16 nas cidades de Belém, S. Luiz, Fortaleza, Recife, Bahia, S. Paulo e Porto Alegre; de 10 nas outras capitaes e nas cidades de 20.000 habitantes, segundo o ultimo recenseamento concluido e publicado; de 4 a 8 nos mais termos, segundo o seu movimento commercial; c) a designação será feita por qualquer numero do commerciantes que compareçam, e, nenhum comparecendo, a fará o juiz. Serão tambem designados pelo juiz os quatro a oito nomes, nos termos a que se refere a disposição antecedente; d) a lista será alterada de metade biennalmente, publicada pela imprensa e registrada depois de organisada por ordem numerica; e na mesma ordem cada um será nomeado e obrigado a servir, sob multa de $200 \$$ a 1:000\$, salvo motivo attendivel, á apreciação do juiz; e) a designação recahirá em commerciantes de fama illibada, notoriamente abonados e que conheçam os negocios. $\S 2^{\circ} \mathrm{O}$ fallido será obrigado a apresentar em juizo, dentro de 24 horas, sob pena de prisão por 30 dias, a lista de seus 10 maiores credores. Dentre estes dez maiores credores nomeará o juiz a commissão fiscal. Findas as 24 horas, que correrão do resumo da sentença á porta do fallido, si a lista de credores não estiver em cartorio, o escrivão lavrará certidão nos autos, e, independente de qualquer consulta ao juiz, de 
partir de relação elaborada pelas Juntas Comerciais, exigência essa que teve efeito funesto $\left(\right.$ MENDONÇA, 1916, p. 83) ${ }^{18}$.

Entendendo que a Lei $\mathrm{n}^{\circ} 859$, de 16.8.1902, necessitava regulamentação, foi editado o Decreto $n^{\circ} 4.855$, de 2.6.1903, publicado no Diário Oficial de 3.6.1903 e republicado, em virtude de incorreções na primeira publicação, na edição de 7.6.1903, mas, "com surpresa geral, nesse mesmo Diário, publicou-se de novo a lei n. 859, de 16 de agosto de 1902, com o texto divergente em muitos pontos da mesma lei havia mais de nove mezes devidamente publicada e em execução" (MENDONÇA, 1916, p. 87) ${ }^{19}$.

qualquer recurso intentado pelo fallido, passará contra este mandado de prisão que, assignado pelo juiz, será cumprido incontinenti. Na falta da lista dos credores serão nomeados para a commissão fiscal o credor que houver requerido a fallencia e outro credor por este indicado. $\S 3^{\circ}$ Não poderá ser nomeado syndico ou membro da commissão fiscal parente do fallido até o $4^{\circ}$ gráo civil.

${ }^{18}$ Segundo REQUIÃO (1975, p. 20), “um dos pontos graves da reforma, no qual se depositavam grandes esperanças, pois visava impedir os conluios entre credores e devedor, era a nomeação dos administradores da massa falida, isto é, dos síndicos. Passavam eles a ser escolhidos fora dos quadros da falência, dentre os nomes de uma lista organizada pelas Juntas Comerciais. Os quarenta inscritos nesta lista, no Distrito Federal, dadas as suas sinuosas atividades, logo foram alcunhados, pela verve carioca, de 'Ali Babá e os quarenta ladrões'..."

${ }^{19}$ A título exemplificativo pode ser citado o art. 11 da Lei $\mathrm{n}^{\circ}$ 859, de 16.8.1902, que em uma das versões publicada dispunha que "antes da sentença de declaração da fallencia, emquanto se proceder ás diligencias preliminares, poderá o Juiz, ex-officio ou a requerimento do justificante, decretar o sequestro dos livros, correspondencia, titulos e bens do devedor, para salvaguarda do activo, nos casos do art. $1^{\circ}$, $\S 1^{\circ}$ " ("Art. $1^{\circ} \mathrm{O}$ commerciante, sob firma individual ou social, que sem relevante razão de direito deixa de pagar no vencimento qualquer obrigação mercantil liquida e certa $\left(\operatorname{art.} 2^{\circ}\right)$, entende-se fallido, qualquer que seja o estado de seus negocios. $\S 1^{\circ}$ Caracteriza-se tambem o estado de fallencia, embora não haja falta de pagamentos, si o devedor: a) realizar pagamentos usando de meios ruinosos e fraudulentos; b) transferir ou ceder bens a uma ou mais pessoas, credoras ou não, com obrigação de solver dividas vencidas e não pagas; c) occultar-se, ausentar-se furtivamente, mudar de domicilio sem sciencia dos credores, ou tentar fazel-o, revelado esse proposito por actos inequivocos; d) alienar, sem sciencia dos credores, os bens que possue, fazendo doações, contrahindo dividas extraordinarias ou simuladas pondo os bens em nome de terceiros ou commettendo algum outro artificio fraudulento; e) alienar os bens immoveis, hypothecal-os, dal-os em antichrese, ou em penhor os moveis, sem ficar com algum ou alguns equivalentes ás dividas, livres e desembargados ou tentar praticar taes actos, revelado esse proposito por actos inequivocos; f) fechar ou abandonar o estabelecimento, desviar todo ou parte do activo; g) occultar bens e moveis da casa; h) proceder dolosamente a liquidações precipitadas; i) não pagar, quanto executado por divida commercial, ou não nomear bens á penhora dentro das 24 horas seguintes á citação inicial da execução; j) recusar, como endossador ou sacador, prestar fiança no caso do art. 390 do Codigo Commercial; k) não evitar o concurso de preferencia em execução commercial (art. $609 \S 2^{\circ}$ do reg. n. 737 de 25 de novembro de 1850)")., enquanto na outra versão publicada da Lei $n^{\circ}$ 859 , de 16.8 .1902 , a remissão era ao $\S 2^{\circ}$ do art. $1^{\circ}$. ("§ $2^{\circ}$ Si bem que dividas civis só por si não autorizem a declaração da, fallencia, podem, todavia, concorrer com obrigações mercantis para constituir o estado della."). De igual modo, o art. 98 da Lei ${ }^{\circ} 859$, de 16.8.1902, pois em uma das publicações dispunha ser "competente para declarar a fallencia o tribunal do domicilio commercial, do devedor, ainda que tenha praticado accidentalmente actos de commercio em outra nação, ou nella mantenha agencias filiaes que operem por conta e sob responsabilidade do estabelecimento principal", enquanto na outra publicação essa norma estabelecia ser "competente para declarar a fallencia o tribunal do domicilio commercial, do devedor, ainda que não tenha praticado accidentalmente actos de commercio em outra nação, ou nella mantenha agencias filiaes que operem por conta e sob responsabilidade do estabelecimento principal." 
As divergências existentes nas duas publicações da Lei no 859 não se referiam ao único meio que o devedor em dificuldade financeira poderia empregar para evitar a decretação de sua falência, qual seja, a concordata preventiva, consistente em acordo com os credores, que somente seria passível de homologação judicial se determinados requisitos legais (art. 54) fossem preenchidos, requisitos esses referentes, fundamentalmente, ao quorum de aprovação pelos credores e ao prazo para pagamento dos débitos quirografários, únicos sujeitos à concordata. ${ }^{20}$

Durante o processamento e o período de cumprimento da concordata preventiva, os administradores do devedor eram mantidos no exercício de seus cargos, mas a lei, em seu art. 122, condicionava à autorização judicial a prática de determinados atos, a saber, a alienação de bens, a constituição de hipoteca e a assunção de novas obrigações ${ }^{21}$.

É de se destacar ainda que a lei exigia autorização judicial para a prática desses atos apenas durante o processo de homologação da concordata preventiva, de modo que, após a manifestação dos credores aceitando ou recusando a proposta de concordata, ou juiz decretava a falência ou homologava a concordata ${ }^{22} 23$, hipótese na qual os administradores

${ }^{20}$ Art. 54 . A concordata só será válida quando concedida: a) por maioria dos credores, representando mais de
metade do valor dos creditos, si o dividendo for superior a $50 \%$; b) por dous terços dos credores,
representando tres quartos do valor dos creditos, ou tres quartos dos credores, representando dous terços do
valor dos creditos, si o dividendo não for inferior de $30 \%$; c) por tres quartos dos credores e do valor dos
creditos, si o dividendo fôr menor de $30 \%$;) si for ajustado prazo para pagamento, não excederá este de
dous annos, salvo si maior fôr concedido por $3 / 4$ dos credores, representando $3 / 4$ do valor dos creditos. Serão
computados sómente os creditos reconhecidos verdadeiros e admittidos ao passivo, com exclusão dos
credores da massa e de dominio (reivindicantes) separatistas, privilegiados e hypothecarios. $\S 1^{\circ}$ A proposta
de concordata poderá ser apresentada com declaração escripta e assignada pelos credores, devidamente
authenticada, concedendo-a; nesse caso o valor dos creditos e o numero dos credores se apurarão de
conformidade com este artigo. $\S 2^{\circ}$ Si os credores a que se refere a ultima parte deste artigo quizerem tomar
parte na deliberação da concordata, acceitando-a ou rejeitando-a, ficarão equiparados aos chirographarios.
$\S 3^{\circ}$ Os credores contestados, quando em açãa regular forem julgados legitimos, não ficarão sujeitos aos
creditos da concordata. $\S 4^{\circ}$ Os credores por titulos não mercantis, si não se tratar de fallencia de sociedade,
ficam sujeitos aos effeitos da concordata. ${ }^{21}$ Art. 122. Durante o processo da homologação não poderá o devedor alienar ou hypothecar seus bens, nem contrahir novas obrigações sem autorização do juiz, que procederá ás informações necessarias.

${ }^{22}$ Art. 116. Distribuida a petição, publicará o escrivão edital pela imprensa, onde a houber, e dirigirá carta aos credores, conforme estiverem presentes ou não, communicando o accordo proposto, e intimando-os para, no prazo de 10 dias, remetterem a juizo, além do seu voto de acceitação ou recusa, os documentos em que fundam o seu credito, cobrando recibo do escrivão. Findo este prazo, o juiz marcará o de 10 dias para, dentro delle, o impetrante e os credores allegarem e provarem qualquer reclamação, observadas as disposições do art. 49, alinea, sobre a prova e authenticidade dos titulos particulares. Encerrado o decendio, o juiz, procedendo ao exame dos livros do devedor e do credor, si houver contestação, e outras diligencias que julgar precisas, com o concurso de uma commissão de dous credores, que nomeará, homologará ou não, dentro de oito dias, devendo no caso negativo decretar a fallencia do devedor. A taes diligencias assistirá o curador fiscal das massas falidas. 
do devedor poderiam alienar bens, constituir hipoteca e contrair novas obrigações independentemente de autorização judicial.

A Lei $\mathrm{n}^{\circ} 859$, de 16.8.1902, também contemplava a hipótese de o falido requerer a concessão de concordata suspensiva, que consistia, segundo o comando expresso do art. 53, na "manutenção do devedor na posse da massa pelo tempo accordado para pagamento dos credores, nos termos propostos e acceitos. Não libera o devedor dos effeitos criminaes da fallencia e só depois de cumprida é que o desonera dos seus effeitos civis e commerciaes. Emquanto não estiver cumprida a concordata, o devedor concordatario será considerado depositario dos bens da massa com poderes de disposição e administração." Em outras palavras, a concordata concedida durante o processamento da falência não a suspendia, mas atribuía ao devedor, ou seus administradores, se sociedade dotada de personalidade jurídica, a administração da massa, inclusive com poderes para alienar bens ${ }^{24}$.

\subsection{A Lei $\mathbf{n}^{0} \mathbf{2 . 0 2 4}$, de 17.12.1908}

Em virtude das críticas e dos questionamentos a respeito da Lei $\mathrm{n}^{\circ} 859$, de 16.8.1902, seu prazo de vigência foi exíguo, tendo sido revogada pela Lei $\mathrm{n}^{\circ} 2.024$, de 17.12.1908, a qual estabelecia a concordata preventiva como único meio que o devedor poderia empregar para superar suas dificuldades econômico-financeiras e evitar a declaração de sua falência ${ }^{25}$.

Exigia a lei, como condição para o processamento do pedido de concordata preventiva, que o devedor propusesse pagar aos credores no mínimo $20 \%$ do valor de seus créditos, bem como oferecesse garantia do cumprimento dessa obrigação proposta ${ }^{26}$. Daí que, como a concordata preventiva exigia a concessão de garantias, estavam a ela sujeitos

${ }^{23}$ Art. 117. A homologação não terá logar si o accordo ou concordata não for estipulado na fórma prevista no art. 54.

24 Art. 60. A concordata definitivamente acceita, induz: a) á entrega da massa ao devedor para liquidal-a, como entender, sob a fiscalização da comissão de que trata o art. 58; b) á prestação de contas dos syndicos.

25 Art. 149. O devedor commerciante poderá evitar a declaração de sua fallencia, requerendo ao juiz do commercio, em cuja jurisdicção se acha o seu principal estabelecimento, a convocação dos credores para lhes propôr concordata preventiva.

${ }^{26}$ Art. $149, \S 1^{\text {o }}$ - No requerimento, o devedor explicará os motivos da sua deliberação, o seu estado econômico, as garantias que oferece para o pagamento de mais de $20 \%$ aos credores chirographarios e indicará as clausulas e condições da sua proposta. 
apenas os créditos originalmente despidos de garantias (ou seja, quirografários), porquanto os privilegiados e os titulares de créditos com garantia real somente se subordinariam a ela se renunciassem às suas próprias garantias ${ }^{27}$.

E pela mesma razão, a Lei $n^{\circ} 2.024$, de 17.12.1908, em seu art. 160, proibia as sociedades por ações de requerer a concordata preventiva ${ }^{28}$, pois como destaca MENDONÇA (1917, p. 495)

\begin{abstract}
Á vista do caracter executivo que a lei n. 2.024 imprimiu á fallencia, só por condescendencia fôra addmitida a concordata preventiva. Era razoavel pois, que a lei reduzisse o mais possivel a concessão deste extraordinario favor, permittindo-o somente a quem podesse offerecer aos credores effectivas garantias reaes e pessoaes e se apresentasse como devedor honesto.

Ella prohibiu que requeressem a concordata preventiva:

I - As sociedades anonymas, porque, não havendo a garantia pessoal dos socios, poderiam os seus administradores deshonestos abusar do favor, convertendo-o em arma de fraude.
\end{abstract}

Durante o processamento da concordata preventiva, o devedor conservava a administração de seus bens e de seu negócio, mas a prática de determinados atos, tais como a alienação de imóveis, a constituição de garantias reais e a contratação de novas obrigações estavam subordinadas à obtenção de autorização judicial, subordinação essa que persistia até o integral cumprimento de todas as obrigações assumidas na concordata preventi-

${ }^{27}$ Art. 155. A proposta de concordata preventiva, para ser válida e produzir efeitos jurídicos, deve ser aceita nos mesmos termos do art. 106, applicando-se-lhe também as disposições dos $\S \S 1^{\circ}, 2^{\circ}, 3^{\circ}, 4^{\circ}$ e $7^{\circ}$ do mesmo artigo, sendo que não poderão votar os cessionarios de créditos, cuja cessão tenha menos de um anno.

Os parágrafos $2^{\circ}$ e $3^{\circ}$ do referido art. 106 , por seu turno, estabeleciam: "§ $2^{\circ}$ Para formar a maioria exigida para a validade da concordata, não se computarão: 1 . Os creditos garantidos por hypotheca, privilegios, penhores antichrese ou direito de retenção. 2. Os creditos dos parentes até o $4^{\circ}$ gráo e cessionarios delles, tendo a cessão menos de um anno. 3. Os creditos cedidos mediante actos inter vivos, ainda mesmo por endosso, depois do dia em que fôr declarada a fallencia. Nessa disposição não se comprehendem os fiadores que pagarem a divida do fallido, ficando subrogados nos direitos dos credores. $\S 3^{\circ}$ Os titulares de creditos referidos no $\S 2^{\circ}$, n. 1 , poderão tomar parte na votação da concordata, computando-se esses creditos no respectivo calculo, si renunciarem ás garantias."

${ }^{28}$ Embora não pudessem requerer concordata preventiva, as sociedades por ações estavam sujeitas à decretação de falência e poderiam propor concordata aos credores, pois o caput do art. 103 dispunha que "depois da verificação dos creditos o fallido poderá propôr concordata a seus credores", acrescentando o § $2^{\circ}$ que "na fallencia das sociedades anonymas, que não estiverem em liquidação, a proposta de concordata deverá ser apresentada, em nome da sociedade, pelos administradores autorizados, para esse fim, por accionistas representando pelo menos dous terços do capital social." 
va, salvo se na proposta aprovada pelos credores houvesse disposição diversa (art. 157, caput e $\S$ único ${ }^{29}$.

A importância da manutenção do devedor na administração do negócio se justificava, segundo MENDONÇA (1917, p. 492), porque

É sempre mais util e proveitosa (e a pratica mostra os salutares resultados) uma liquidação amigavel a cargo de pessoa competente e entendida, como é o devedor que esteve á frente do estabelecimento, do que a liquidação judicial, consequencia da fallencia. E emquanto não se descobre cousa mais perfeita do que estes convenios ou concordatas, não devem taes alvitres ser desprezados.

O proprio interesse publico justifica a concordata preventiva, pois se a fallencia desanima o fallido e lhe rouba o estimulo, aquella é um incentivo ao trabalho.

Em outras palavras, a concordata preventiva, com a manutenção do devedor na condução do negócio, além de evitar solução de continuidade nas atividades do comerciante ou sociedade comercial, era um incentivo à superação da crise econômico-financeira.

Isso não obstante, se fosse decretada a falência, hipótese na qual o devedor era afastado da administração de seus bens, o falido tinha a possibilidade de propor concordata a seus credores, a qual, para ser concedida, dependia do preenchimento de determinados requisitos legais, bem como da aprovação pelos credores e da homologação judicial. Essa concordata somente obrigava os credores quirografários, motivo pelo qual um dos requisitos para sua concessão era o integral pagamento de todos os credores privilegiados e titulares de garantia real.

Ademais, no sistema da Lei $\mathrm{n}^{\circ} 2.024$, de 17.12.1908, a concordata importava na extinção da falência, com a consequente restituição ao devedor de todos os bens da massa, podendo deles livremente dispor, restituição essa que somente ocorreria após o pa-

\footnotetext{
${ }^{29}$ Art. 157. Durante o processo da concordata preventiva, o devedor conservará a administração de seus bens e continuará com o seu negocio, sob a fiscalização dos commissarios, mas não poderá alienar ou hypothecar immoveis, nem constituir penhores, nem contrahir novas obrigações, salvo com autorização expressa do juiz, por evidente utilidade, ouvidos os commissarios. Paragrapho unico. A prohibição de alienar e hypothecar immoveis e constituir penhores sobre generos ou mercadorias subsistirá emquanto a concordata não fôr cumprida, salvo pacto expresso em contrario na concordata.
} 
gamento de todos os credores não sujeitos à concordata ${ }^{30} 31$. Em outras palavras, extinta a falência, ao devedor era restituída a administração de seus bens, com plenos poderes de disposição e oneração.

\subsection{O Decreto $n^{\circ} 5.746$, de 9.12 .1929}

Referida Lei $\mathrm{n}^{\mathrm{o}}$ 2.024, de 17.12.1908, permaneceu em vigor por mais de duas décadas, tendo sido revogada pelo Decreto $\mathrm{n}^{\circ}$ 5.746, de 9.12.1929, o qual manteve a concordata preventiva como único meio à disposição do devedor para superar suas dificuldades econômico-financeiras e evitar a declaração de sua falência. E, assim como na revogada Lei $n^{\circ} 2.024$, de 17.12.1908, no novel Decreto $n^{\circ} 5.746$, de 9.12.1929, a concordata preventiva também estava regulada no Título XI, que se iniciava no mesmo art. 149, cuja redação também era muito similar ${ }^{32}$.

Na nova legislação, porém, o devedor deveria oferecer ao credores quirografários, únicos sujeitos à concordata preventiva ${ }^{33}$, o pagamento do valor correspondente a, no

${ }^{30}$ Art. 112. Os bens da massa sómente serão entregues ao concordatario, depois de pagar ou depositar em
juizo a importancia: 1 . devida aos credores privilegiados sem garantias especiaes, não sujeitos aos effeitos da
concordata, e 2. de todas as despezas do processo e da administração da massa. Paragrapho unico. Si o
concordatario, dentro de 15 dias, depois de homologada definitivamente a concordata, não cumprir a
disposiçãa deste artigo, aquella considera-se rescindida de pleno direito, proseguindo a fallencia. ${ }^{31}$ Art. 113. A concordata homologada obriga todos os credores commerciaes ou civis não privilegiados, admittidos ou não á fallencia, residentes e não residentes na Republica, ausentes ou dissidentes.

32 O art. 149 do Decreto $\mathrm{n}^{\circ}$ 5.746, de 9.12.1929, dispunha: "O devedor commerciante poderá evitar a declaração de sua fallencia, requerendo ao juiz, em cuja jurisdicção se acha o seu estabelecimento principal, a convocação dos seus credores para lhes propôr concordata preventiva", enquanto o art. 149 da revogada Lei $\mathrm{n}^{\mathrm{o}}$ 2.024, de 17.12.1908, tinha a seguinte redação: "O devedor commerciante poderá evitar a declaração de sua fallencia, requerendo ao juiz do commercio, em cuja jurisdiç̧ão se acha o seu principal estabelecimento, a convocação dos credores para lhes propôr concordata preventiva."

${ }^{33} \mathrm{O}$ caput do art. 158 estabelecia que "São inteiramente applicaveis á concordata preventiva as disposições dos arts. 81, 82, 83, 85, 86, 87, 91, 92, 93, 94, 99, 105, 106, 108, 109, 113, 114, primeira alinea, 115, 117, 118 e 120."

E o art. 113, por sua vez, que regulava a concordata apresentada no curso da falência, dispunha: "A concordata homologada obriga todos os credores commerciaes ou civis não privilegiados, admittidos ou não á fallencia, residentes ou não residentes na Republica, ausentes ou dissidentes. Paragrapho único. Si o concordatario recusar o cumprimento da concordata para o credor chirographario que se não habilitou, poderá este accionar o devedor pela acção que couber ao seu titulo, para haver a importancia total do seu credito."

De igual modo, o art. 155 determinava que "a proposta da concordata preventiva, para ser valida e produzir effeitos juridicos, deve ser acceita nos mesmos termos do art. 106, applicando-se-lhe tambem as disposições dos paragraphos $1^{\circ}, 2^{\circ}, 3^{\circ}, 4^{\circ}, 7^{\circ}$ e $8^{\circ}$ do mesmo artigo, sendo que não poderão votar os cessionarios de creditos, cuja cessão tenha menos de um anno. Paragrapho único. Não se computarão, para a formação da maioria legal, os creditos dos parentes dos socios solidarios da firma concordataria e dos socios das sociedades por quotas." 
mínimo, $40 \%$ do montante total dos créditos a ela sujeitos se o pagamento fosse à vista, caso em que sua aprovação exigia quórum de $70 \%$ do valor dos créditos quirografários. Se a prazo, o valor mínimo que devia ser ofertado pelo devedor era fixado em função do prazo previsto para o pagamento dos credores ${ }^{34}$.

Também da mesma forma que a revogada Lei $\mathrm{n}^{\circ} 2.024$, de 17.12.1908, o Decreto $\mathrm{n}^{\circ}$ 5.746, de 9.12.1929, no art. 159, expressamente proibia as sociedades anônimas de impetrarem pedido de concordata preventiva ${ }^{35}$.

E seguindo a tradição de todas as legislações falimentares anteriores, durante o processamento da concordata preventiva, para evitar qualquer solução de continuidade nas atividades do devedor, ele conservava a administração de seus bens e prosseguia na condução de seu negócio. Havia, porém, restrições à pratica de atos que importassem na alienação ou na oneração de bens, os quais somente poderiam ser implementadas se contasse expressa autorização judicial, após a manifestação do comissário ${ }^{36}$. E essa restrição à reali-

E os parágrafos $2^{\circ}$ e $3^{\circ}$ do art. 106 acrescentavam que os créditos privilegiados ou com garantia somente votariam nas assembleias de credores se seus titulares renunciassem à garantia, hipótese na qual passariam a se subordinar aos efeitos da concordata, de onde decorre que apenas os créditos quirografários estavam sujeitos ao favor legal: " $\$ 2^{\circ}$ Para formar a maioria exigida para a validade da concordata, não se computarão: $1^{\circ}$ os creditos garantidos por hypotheca, privilegios, penhores, antichése ou direito de retenção; $2^{\circ}$ os creditos dos parentes até o $4^{\circ}$ gráo, por consanguinidade ou affinidade, e cessionarios delles, tendo a cessão menos de um anno; $3^{\circ}$ os creditos cedidos mediante actos "inter vivos", ainda menos por endosso, depois do dia em que for declarada a fallencia. Nessa disposição não se comprehendem os fiadores que pagarem a divida do fallido, ficando subrogados nos direitos dos credores. $\S 3^{\circ}$ Os titulares de creditos referidos no $\S 2^{\circ}$, n. 1 , poderão tomar parte na votação da concordata, computando-se esses creditos no respectivo calculo, se renunciarem ás garantias. $\mathrm{O}$ facto de votar importa essa renuncia e sujeita os titulares aos effeitos da concordata. Os effeitos da renuncia cessarão si a concordata não for homologada ou si fôr rescindida, salvo o caso de conluio referido no art. 108, n. 3."

${ }^{34}$ Art. 106. A proposta de concordata, para ser valida e produzir effeitos juridicos, si o pagamento fôr á vista, não será inferior a quarenta por cento e deverá ser acceita por maioria de credores: a) representando pelo menos $60 \%$ do valor dos creditos si o dividendo offerecido fôr superior a $50 \%$; b) representando pelo menos $65 \%$ do valor dos creditos si o dividendo offerecido fôr superior a $45 \%$; c) representando pelo menos $70 \%$ do valor dos creditos si o dividento offerecido fôr igual ou superior a $40 \%$. $\S 1^{\circ} \mathrm{Si}$ o pagamento fôr a prazo, que não poderá ser maior de dous annos, a proposta deverá ser apoiada por dous terços de credores, representando pelo menos $75 \%$ dos creditos e não poderá ser inferior: a) a $50 \%$ si o prazo fôr de 6 mezes; b) a $55 \%$ si o prazo fôr de 12 mezes; c) a $60 \%$ si o prazo fôr de 21 mezes.

35 Também de modo idêntico ao que dispunha a anterior Lei $\mathrm{n}^{\mathrm{o}} 2.024$, de 17.12.1908, no regime do Decreto $\mathrm{n}^{\circ}$ 5.746, de 9.12.1929, as sociedades por ações estavam sujeitas à decretação de falência e poderiam propor concordata aos credores: “Art. 103. Depois da verificação dos creditos o fallido poderá propôr concordata a seus credores. (...) $\S 2^{\circ} \mathrm{Na}$ fallencia das sociedades anonymas, que não estiverem em liquidação, a proposta de concordata deverá ser apresentada, em nome da sociedade, pelos administradores autorizados, para esse fim, por accionistas representando pelo menos dous terços do capital social."

${ }^{36} \mathrm{O}$ art. 150 estabelecia que o juiz, no despacho que recebia a proposta de concordata preventiva, nomearia um comissário, para cuja escolha deviam ser obedecidos os mesmos critérios empregados para a nomeação do síndico, os quais vinham dispostos no art. 64: "Na sentença declaratoria da fallencia, o juiz nomeará um 
zação de certos atos de alienação e de oneração, exceto mediante autorização judicial após manifestação do Ministério Público, ou expressa convenção em contrário ${ }^{37}$, mantinha-se até o cumprimento da concordata.

Caso, porém, a falência fosse decretada, o devedor tinha a possibilidade de propor concordata a seus credores quirografários, a qual, se aprovada por eles e homologada judicialmente, importava na extinção do processo de falência e a restituição ao devedor de todos os bens da massa, livros e papéis (art. 111). Isso não obstante, a alienação e a oneração de bens imóveis dependiam de autorização judicial se a concordata fosse a prazo (art.

syndico para, sob sua immediata direcção, administrar a massa, inventariar bens e proceder aos trabalhos da verificação de creditos. $\S 1^{\circ} \mathrm{O}$ syndico será escolhido entro os credores do falido, residentes ou domiciliados no fôro da fallencia, de reconhecida idoneidade moral e financeira. Não constando dos autos a relação credores, o juiz poderá mandar notificar o devedor, si estiver presente, para apresental-a em cartorio dentro de duas horas e sob pena de prisão até trinta dias. Si não houver credores que acceitem o cargo, o juiz poderá nomear para syndico pessoas estranhas, idoneas e de bôa fama. $§ 2^{\circ}$ Não poderá servir de syndico: a) o que tiver laço de consanguinidade ou affinidade até o quarto gráo civil com o fallido ou com os directores e gerentes das sociedades fallidas, ou destes forem amigos, inimigo ou dependentes; b) o cessionario da creditos, desde um anno antes de ser requerida a fallencia; c) aquelle que, tendo exercido o cargo de syndico ou liquidatario em outra fallencia, ou de commissario em concordata preventiva, foi destituido, ou não prestou contas dentro dos prazos legaes, ou tendo-as prestado, foram julgadas más, nos termos do art. $71, \S \S 4^{\circ}$ e $6^{\circ}$; d) os que já houverem sido nomeados pelo mesmo juiz, dentro de um anno, sendo pessôas estranhas a fallencia em ambos os casos; e) aquelle que ha menos de seis mezes, sendo nomeada pelo, juiz, recusou igual cargo em fallencia de que era credor. $\S 3^{\circ}$ Dentro de quarenta e oito horas, depois do edital referido no art. 18, qualquer interessado poderá reclamar, por petição, ao juiz contra a nomeação do syndico em contravenção a esta lei. O juiz, attendendo ás allegações e provas, decidirá dentro de vinte e quatro horas. $\S 4^{\circ} \mathrm{Si}$ o syndico nomeado fôr pessoa juridica, declarar-se-ha no termo de que trata o art. 65 , o nome de seu representante, que não poderá ser substituido sem licença do juiz."

As funções do comissário, nos termos do $\S 1^{\circ}$ do art. 151 eram fundamentalmente: " $1^{\circ}$ annunciar pela imprensa que se acha á disposição dos interessados para receber reclamações, declarando o logar e a hora em que será encontrado; $2^{\circ}$ fiscalizar a conducta do devedor na administração do seu negocio e bens, emquanto se processa a concordata preventiva; $3^{\circ}$ examinar todos os livros e papeis do devedor, verificar o activo e passivo e solicitar dos interessados todas as informações que achar uteis; $4^{\circ}$ averiguar e estudar quaesquer reclamações dos interessados, emitir parecer sobre ellas para ser apresentado na assembléa dos credores; $5^{\circ}$ verificar si o devedor praticou actos, que a massa poderia revogar em seu beneficio, no caso de fallencia; $6^{\circ}$ apresentar, em cartorio, até tres dias antes da assembléa, um relatorio minucioso sobre a situação economica do devedor, sobre a lealdade com que tem gerido o seu negocio, sobre o valor do activo e sobre as garantias offerecidas; $7^{\circ}$ fazer a todos os credores, commerciaes e civis, por circulares, convite para apresentarem as suas declarações de credito, nos termos do art. 82, que no convite será transcripto, e para comparecerem á assembléa. $8^{\circ}$ quando o concordatario offerecer garantia real, cuja outorga dependa de instrumento público, deverá o commissario, com assistência do representante do Ministério Público, receber, em nome dos credores, a respectiva escriptura; juntando-a ao relatorio do que trata o n. 6, deste artigo, para os fins do art. 154."

${ }^{37}$ Art. 156. Durante o processo da concordata preventiva, o devedor conservará a administração de seus bens e continuará com o seu negocio, sob a fiscalização do commissario, mas não poderá alienar ou hypothecar immoveis, nem constituir penhores, nem contrahir novas obrigações, salvo com autorização expressa do juiz, por evidente utilidade, ouvido o commissario. Paragrapho único. Subsistirá a prohibição de alienar e onerar immoveis e constituir penhor emquanto não for cumprida a concordata, podendo, entretanto, ser relevada, mediante licença judicial, com audiencia do representante do Ministério Público, salvo pacto expresso em contrario no acto da sua concessão. 
$111, \S 1^{\circ}$ ), e a transferência do estabelecimento exigia concordância expressa da totalidade dos credores (art. 111, § $2^{\circ}$ ).

\title{
1.6. O Decreto-Lei $n^{0}$ 7.661, de 21.06.1945
}

O Decreto $\mathrm{n}^{\circ}$ 5.746, de 9.12.1929, permaneceu em vigor até 31.10.1945, quando foi revogado pelo Decreto-Lei $n^{\circ}$ 7.661, de 21.06.1945, que, segundo FERREIRA (1965, p. 49) teve "o deliberado propósito de beneficiar ao devedor, em detrimento dos credores", porquanto

\begin{abstract}
A nova lei mostrou-se inexorável contra os credores, restringindo-lhes o exercício de seus direitos creditórios. Não mais lhes é dado intervir no processo liquidatório, elegendo o liquidatário. Nem, tampouco intervir na concordata, preventiva ou suspensiva da falência, senão em têrmos que lhes impossibilitam verdadeiramente defender, eficientemente, seus créditos. Instituiu-se, com evidente espírito fascista, o que impròpriamente se tem chamado de concordata de autoridade. Ainda que os credores, unânimemente, se lhe oponham, ao Juiz é dado outorgá-la. Tudo pode ser isso, menos concordata.
\end{abstract}

O Decreto-Lei $\mathrm{n}^{\mathrm{o}} 7.661$, de 21.06.1945, assim, oferecia ao devedor em dificuldade, como meio para evitar a declaração de falência, a denominada concordata preventiva, para cuja concessão bastava o cumprimento de requisitos objetivos, independentemente da viabilidade econômica do devedor e da vontade dos credores $^{38}$. Mas, assim como nas legislações anteriores, apenas os credores quirografários estavam sujeitos à concordata preventiva, sendo que exclusivamente ao devedor competia definir se esses seus débitos

\footnotetext{
${ }^{38}$ Os artigos 140 e 158 estabeleciam os requisitos que o devedor devia cumprir para ser concedida concordata preventiva, a saber:

“Art. 140. Não pode impetrar concordata: I - o devedor que deixou de arquivar, registrar, ou inscrever no registro do comércio os documentos e livros indispensáveis ao exercício legal do comércio; II - o devedor que deixou de requerer a falência no prazo do art. $8^{\circ}$; III - o devedor condenado por crime falimentar, furto, roubo, apropriação indébita, estelionato e outras fraudes, concorrência desleal, falsidade, peculato, contrabando, crime contra o privilégio de invenção ou marcas de indústria e comércio e crime contra a economia popular; IV - o devedor que há menos de cinco anos houver impetrado igual favor ou não tiver cumprido concordata há mais tempo requerida."
}

“Art. 158. Não ocorrendo os impedimentos enumerados no art. 140, cumpre ao devedor satisfazer as seguintes condições: I - exercer regularmente o comércio há mais de dois anos; II - possuir ativo cujo valor corresponda a mais de cinqüenta por cento do seu passivo quirografário; na apuração dêsse ativo, o valor dos bens que constituam objeto de garantia, será computado tão a sòmente pelo que exceder da importância dos créditos garantidos; III - não ser falido ou, se o foi, estarem declaradas extintas as suas responsabilidades; IV - não ter título protestado por falta de pagamento." 
seriam pagos à vista ou a prazo, respeitados os critérios fixados no art. 156 do novo diplo$\mathrm{ma}^{39}$.

Durante o processo da concordata preventiva o devedor conservava a administração dos seus bens e continuava gerindo seu negócio, mas sob a fiscalização do comissário. Isso não obstante, a alienação de imóveis e a constituição de garantias reais dependia de autorização judicial, depois de ouvido o comissário ${ }^{40}{ }^{41}$.

Em outras palavras, como destacava VALVERDE (1999, p. 324):

o despacho que determina o processamento do pedido de concordata não acarreta nenhuma incapacidade para o devedor, que continua no gozo de todos os seus direitos civis e políticos. Ameaçado, com a abertura da sua falência, de perder a posse e administração de seus bens e deles dispor, com o deferimento do pedido de concordata evita o devedor a falência e se mantém na posse e administração dos bens e com a faculdade, embora restrita, de dispor deles. As limitações à sua atividade são poucas.

Essa legislação também facultava ao devedor falido a possibilidade de suspender o processo de falência mediante a concessão de concordata suspensiva, cujo deferimento judicial independia da vontade dos credores, bastando o cumprimento de determinados requisitos legais (art. $177^{42}$ ). Neste caso, após o trânsito em julgado da sentença que con-

${ }^{39}$ Art. $156 \mathrm{O}$ devedor pode evitar a declaração da falência, requerendo ao juiz que seria competente para decretá-la, lhe seja concedida concordata preventiva. $\S 1^{\circ}$ - O devedor, no seu pedido, deve oferecer aos credores quirografários, por saldo de seus créditos, o pagamento mínimo de: I - 50\%, se for à vista; II - $60 \%$, $75 \%, 90 \%$ ou $100 \%$, se a prazo, respectivamente, de 6 (seis), 12 (doze), 18 (dezoito), ou 24 (vinte e quatro) meses, devendo ser pagos, pelo menos, $2 / 5$ (dois quintos) no primeiro ano, nas duas últimas hipóteses.

40 Art. 167. Durante o processo da concordata preventivo, o devedor conservará a administração dos seus bens e continuará o seu negócio, sob fiscalização do comissário. Não poderá, entretanto, alienar imóveis ou constituir garantias reais, salvo evidente utilidade, reconhecida pelo juiz, depois de ouvido o comissário.

${ }^{41}$ PONTES DE MIRANDA (1971, t. 30, p. 193) destaca que "o patrimônio do devedor é administrado pelo próprio devedor, seja no que entra no fundo do comércio, seja no que nesse não entra. O que a lei determina, a respeito de certos bens, é que somente possam ser alienados com permissão do juiz, que tem a cognição da conveniência do negócio jurídico (art. 167, $2^{\text {a }}$ parte). Não seria acertado que, continuando o negócio, ficasse a atividade do devedor cerceada em todos os atos jurídicos. Outros sistemas jurídicos discrepam de tal solução, mas, de iure condendo, desacertadamente. Se a concordata preventiva é de pessoa jurídica, tudo se há de passar como se pedido de concordata não houvesse existido, no tocante à administração. Lei, contrato social e estatutos é que decidem em cada espécie."

${ }^{42}$ Art. 177. O falido pode obter, observadas as disposições dos artigos 111 a 113, a suspensão da falência, requerendo ao juiz lhe seja concedida concordata suspensiva. Parágrafo único. O devedor, no seu pedido, deve oferecer aos credores quirografários, por saldo de seus créditos, o pagamento mínimo de: I - 35\%, se for a vista; II - 50\%, se for a prazo, o qual não poderá exceder de dois anos, devendo ser pagos pelo menos dois quintos no primeiro ano. 
cedia a concordata, os bens arrecadados eram restituídos ao devedor, a quem se atribuía direito à livre disposição deles (art. $183^{43}$ ), obedecido ao disposto no art. $149^{44}$ do referido Decreto-Lei, o qual se aplicava tanto à concordata suspensiva quanto à preventiva ${ }^{45}$, e condicionada à autorização judicial, após manifestação do Ministério Público, (a) a alienação e a oneração de bens imóveis ou sujeitos a cláusulas da concordata, e (b) ao consentimento expresso de todos os credores a venda e a transferência do estabelecimento.

É de se destacar ainda que no Decreto-Lei $n^{\circ} 7.661$, de 21.06.1945, a eventual condenação do devedor ou de seus administradores pela prática de crime falimentar era causa de convolação da concordata preventiva em falência (art. 150 , inc. VII) ${ }^{46}$, sendo que a mesma consequência havia se se constatasse "negligência ou inação do concordatário na continuação do seu negócio" (art. 150, inc. V) ${ }^{47}$ ou "incontinência de vida ou despesas evidentemente supérfluas ou desordenadas do concordatário" (art. 150, inc. VI) ${ }^{48}$.

${ }^{43}$ Art. 183. Passada em julgado a sentença que conceder a concordata, os bens arrecadados serão entregues
ao concordatário, que readquirirá direito à sua livre disposição, com as restrições estabelecidas no artigo 149;
se a concordata for de sociedade em que haja sócio solidário não comerciante, este receberá, ao mesmo
tempo, os bens que lhe pertençam, readquirindo idêntico direito, sem outras restrições que as das cláusulas da
concordata. Parágrafo único. O prazo para o cumprimento da concordata inicia-se na data em que passar em
julgado a mesma sentença, devendo o concordatário, dentro dos trinta dias seguintes a essa data e sob pena de
reabertura da falência: $\mathrm{I}$ - pagar os encargos e dívidas da massa e os créditos com privilégio geral; II - exibir a
prova das quitações referidas no $\mathrm{n}^{\circ}$ I do art. 174; III - pagar a percentagem devida aos credores
quirografários, se a concordata for a vista. ${ }^{44}$ Art. 149. Enquanto a concordata não for por sentença julga cumprida (art. 155), o devedor não pode, sem prévia autorização do juiz, ouvido o representante do Ministério Público, alienar ou onerar seus bens imóveis ou outros sujeitos a cláusulas da concordata; outrossim, sem o consentimento expresso de todos os credores admitidos e sujeitos aos efeitos da concordata, não lhe é permitido vender ou transferir o seu estabelecimento. Parágrafo único. Os atos praticados pelo concordatário com violação deste artigo, são ineficazes relativamente à massa, no caso de rescisão da concordata.

${ }^{45}$ No Decreto Lei $\mathrm{n}^{\mathrm{0}} 7.661$, de 21.06.1945, a concordata estava regulada no Título X, que era subdividido em três seções distintas: a primeira continha disposições gerais aplicáveis tanto à concordata preventiva quanto à suspensiva (arts. 139 a 155); a segunda regia especificamente a concordata preventiva (arts. 156 a 176); enquanto a terceira seção tratava exclusivamente da concordata suspensiva (arts. 177 a 185).

${ }^{46}$ PONTES DE MIRANDA (1971, t. 30, p. 125) ressalta que "a condenação do concordatário por crime de falência, em se tratando de pessoa física, ou dos órgãos, ou administradores, gerentes ou liquidantes da sociedade em concordata, é pressuposto suficiente para a resolução (Decreto-Lei $\mathrm{n}^{\circ}$ 7.661, art. 150, VII). Na concordata preventiva, evita-se a falência, de modo que não há cogitar-se de possível condenação por crime falencial, salvo se ocultamente o concordatário tinha outro estabelecimento alhures que falira, ou se era sócio solidário de algum estabelecimento alhures que falira. A falência por dívida posterior à concordata é causa de resolução de pleno direito, de modo que, ao ser condenado o devedor por algum crime de falência, é de admitir-se, já estaria resolvida."

${ }^{47}$ PONTES DE MIRANDA (1971, t. 30, p. 124), comentando a norma do art. 150, inc. V. do Decreto-Lei ${ }^{\circ}$ 7.661, de 21.06.1945, esclarece que "o concordatário havia de continuar de explorar o negócio e continuou, em vez de abandoná-lo; mas negligente, ou sem a atividade que fora de mister. Um dos casos de negligência é deixa-lo entregue a pessoa incompetente, ou idônea, como a que foi condenada por crime de abuso de confiança, estelionato ou semelhante. E negligente o concordatário que se ausenta amiúde do lugar em que tem o 
De outro modo: a condenação penal do concordatário (ou do administrador se se tratasse de pessoa jurídica) pela prática de crime falimentar, a contratação de despesas supérfluas e a incapacidade técnico-administrativa do concordatário importavam sempre na convolação da concordata em falência, ainda que a empresa fosse economicamente viável: o devedor ou seu administrador não poderiam ser afastados ou substituídos por terceiro para conduzir os negócios.

O Decreto-Lei $n^{\circ} 7.661$, de 21.06.1945, foi revogado pela Lei $n^{\circ} 11.101$, de 9.2.2005 (LREF), atualmente em vigor, a qual prevê a recuperação judicial como meio para o devedor em dificuldade econômico-financeira superar a crise e evitar a declaração de sua falência. E, do mesmo modo que todas as legislações falimentares anteriores, a LREF estabelece, como regra geral, a manutenção do devedor e de seus administradores na condução da empresa (art. 64), evitando, assim, qualquer solução de continuidade nos negócios, e privilegiando o conhecimento da atividade.

Mas como se buscará examinar ao longo desse trabalho, a atual LREF contempla hipóteses nas quais o devedor, ou seus administradores, podem ser afastados e substituídos, na forma do estatuto ou do contrato social, em cumprimento do plano de recuperação, ou por gestor judicial, eleito pelos credores na forma prevista do art. 65 .

É da tradição do direito positivo brasileiro, assim, a manutenção do devedor e de seus administradores na condução da empresa que se socorre do meio previsto na legislação (tradicionalmente a moratória, a concordata, e agora a recuperação) para superar a crise econômico-financeira, de modo a evitar a declaração de sua falência.

estabelecimento, ou não comparece, por muito tempo, à sede do estabelecimento, ou só o faz apressadamente sem se inteirar do andamento e conclusões dos negócios jurídicos e importe das vendas e aquisições."

48 Acrescenta ainda PONTES DE MIRANDA (1971, t. 30, p. 124) que no inc. VI do art. 150 "a lei tira do modo de viver do concordatário, ou das despesas supérfluas ou desordenadas, que faz, pessoalmente ou não, a ilação de que não se pode confiar no cumprimento extado da concordata. A desproporção entre o necessário e os gastos caracteriza o pressuposto. Por outro lado, o alto padrão de vida do concordatário pode fazer pensar-se em que, na obtenção da concordata, omitiu meios de renda, ou haveres. Seja como for, basta que se alguém e provem o serem incontinentes os hábitos e a desproporcionalidade das despesas, ou o seu desregramento, ou teor de vida, que, sem consistir em excesso de gastos, possa comprometer o cumprimento da concordata." 
Em algumas legislações estrangeiras, porém, a regra é diversa, pois o devedor ou os administradores podem ser afastados desde o momento da apresentação do pedido de proteção judicial, impondo-se, assim, o exame, ainda que superficial e a título exemplificativo, do tratamento jurídico dispensado em algumas legislações estrangeiras à condução do negócio do devedor. 


\section{CAPÍTULO II - ANOTAÇÕES À ADMINISTRAÇÃO DO DEVEDOR} NA LEGISLAÇÃO FALIMENTAR ESTRANGEIRA 


\section{CAPÍTULO II - ANOTAÇÕES À ADMINISTRAÇÃO DO DEVEDOR NA LEGISLAÇÃO FALIMENTAR ESTRANGEIRA}

Nos últimos anos, como destaca RIVERA (2009, p. 11), além do Brasil, diversos países implementaram reformas ou alterações pontuais em suas legislações falimentares, pois estas são diretamente influenciadas pela evolução das condições econômicas. Entre os países cujas legislações falimentares foram alteradas podem ser destacados os Estados Unidos (que alterou o Bankruptcy Code em 2005), França (2005), Itália (2006 e 2007), Colômbia (lei no 1.116, de 2006), Chile (2005), Austrália (Banktupty Legislation Amendment Act de 2002, o qual foi objeto de alterações em 2005 e 2006), Índia (2002), Japão, Turquia (2003 e 2004), Espanha (2003), México (2000), China (2006), Nepal (2005) e Argentina (2002).

Até mesmo o Banco Mundial editou, em abril de 2001, Principles and guidelines for effective insolvency and creditor rights system, cujo objetivo foi o de fazer recomendações de princípios que pudessem ser adotados pelos países em desenvolvimento nas reformas que viessem a ser implementadas em suas legislações falimentares, como forma de assegurar a efetividade tanto dos processos de recuperação do devedor, quando da liquidação do falido, bem como a proteção dos direitos dos credores, considerados essenciais para a estabilidade do sistema financeiro ${ }^{49}$.

Entre as recomendações do Banco Mundial ${ }^{50}$, especificamente em relação à administração das empresas que se valem das medidas judiciais para solucionar as crises econômico-financeiras, o Princípio n ${ }^{\circ} 11$ recomenda:

\footnotetext{
${ }^{49}$ Nos Principles and guidelines for effective insolvency and creditor rights system, o Banco Mundial informa que as recomendações foram extraídas das "melhores práticas internacionais", as quais precisam ser adaptadas às realidades de cada país, especialmente em virtude dos mecanismos predominantes no país relativos à proteção social, à estabilidade das instituições financeiras e do mercado de capitais e à eficiência das regras de governança corporativa.

${ }^{50}$ Para melhor compreensão das recomendações, os Principles and guidelines for effective insolvency and creditor rights system contém glossário onde constam, entre outros, os seguintes verbetes cuja transcrição é importante para o objeto desta dissertação:

Administrator: A person or entity appointed in place of a debtor's management to administer an insolvency proceeding and who is accountable to the court, tribunal or agency with jurisdiction over insolvency cases. As used in this paper, the administrator refers to a qualified and competent office holder or professional who is knowledge able of business matters. There term, as used in many countries, is not susceptible to a con-
} 
There are two preferred approaches in a rehabilitation proceeding: exclusive control of the proceeding by an independent administrator or supervision of management by an impartial and independent administrator or supervisor. Under the second option complete power should be shifted to the administrator if management proves incompetent or negligent or has engaged in fraud or other misbehavior. Similarly, independent administrators or supervisors should be held to the same standard of accountability to creditors and the court and should be subject to removal for incompetence, negligence, fraud or other wrong fulconduct ${ }^{51}$.

Em outras palavras, em suas recomendações o Banco Mundial sugere duas alternativas para a administração da empresa durante o processo de superação de sua crise econômico-financeira: (a) a manutenção dos administradores indicados pelo devedor (opção essa que, como já se destacou, é da tradição do direito positivo brasileiro), hipótese na qual a gestão passará a ser fiscalizada e, se constatada a prática de determinados atos,

sistent meaning. Generally it refers to one appointed to manage the affairs of a business with a view to rehabilitating it. In this paper, the term is used generically to encompass a liquidator as well, even thoughthe term "liquidator" generally refers to one charged with liquidating (as opposed to rehabilitating) the enterprise. In systems where a debtor's management is not replaced by an administrator, the debtor's management is typically responsible for carrying out the duties of an administrator (as with a "debtor in possession" in the United States). Other terms often employed with variances in meaning and duties include trustee, supervisor, examiner, receiver, insolvency administrator." (Tradução livre: Administrador: A pessoa ou entidade nomeada para substituir os administradores do devedor em processo de insolvência e que é responsável perante o tribunal ou órgão com jurisdição sobre o processo de insolvência. Como usado neste artigo, o administrador refere-se a um profissional ou empresa especializada e competente, que reconhecidamente tenha capacidade de administrar empresas. Este termo, como usado em muitos países, não tem sentido único. Geralmente refere-se à pessoa nomeada para gerir os negócios de uma empresa com o objectivo de reabilitá-la. Neste trabalho, o termo é usado de modo genérico e abrange o síndico, ainda que o termo "liquidante" geralmente se refira ao encarredado da liquidação da empresa (em oposição à reabilitação). Nos sistemas onde os administradores do devedor não são substituídos por um administrador nomeado pelos credores ou juízes, os administradores do devedor são os responsáveis pela gestão da empresa (como o "debtor in possession" nos Estados Unidos). Outros termos frequentemente empregados, com variações de significado e deveres, incluem "trustee", supervisor, auditor, receptor, administrador da insolvência).

“Rehabilitation: The process of reorganizing (restructuring) an enterprises' financial relationships to restore its financial well being and render it financially viable. This process may include organizational measures and the restructuring of business and market relationships through debt forgiveness, debt rescheduling, debt-equity conversions and other means. It can also involve selling the business as a going concern, in which case the procedure may be equivalent to similar sales under a liquidation proceeding." (Tradução livre: Reabilitação: O processo de reorganização (reestruturação) financeira de empresas de modo a restaurar seu bem-estar financeiro e torná-la financeiramente viável. Este processo pode incluir medidas organizacionais e de reestruturação dos negócios e relações de mercado por meio de perdão da dívida, renegociação de dívida, as conversões da dívida em capital, e outros meios. Também pode envolver a venda do negócio como uma preocupação constante, caso em que os procedimentos podem ser equivalentes às vendas em um processo de liquidação).

51 Tradução livre: "Existem duas abordagens preferenciais em um processo de recuperação: o controle exclusivo do processo por um administrador independente ou supervisão da gestão por um administrador ou supervisor imparcial e independente. Nesta segunda opção a gestão deve ser transferida se se comprovar que o administrador é incompetente ou negligente ou tiver se envolvido em fraude ou outro mau comportamento. Da mesma forma, dos administradores ou supervisores independentes, no exercício das funções, deve ser exigido o mesmo padrão na prestação de contas aos credores e ao tribunal e devem estar sujeitos à remoção por incompetência, negligência, fraude ou outra má conduta". 
serão eles afastados; e (b) a nomeação, desde logo, de administrador independente para conduzir o negócio.

Explicando o porquê de conter duas opções tão díspares, os Principles and guidelines for effective insolvency and creditor rights system informam que a substituição dos administradores durante todo o curso do processo de recuperação, exceto em situações excepcionais, pode causar danos maiores do que os que se busca superar, pois a certeza da substituição é um desincentivo à busca da recuperação: em um momento crítico para a gestão, os administradores resistirão o máximo de tempo possível, de modo a permanecerem conduzindo o negócio.

Em contrapartida, a manutenção dos administradores do devedor também pode representar problemas para a gestão do devedor, pois em um momento em que a empresa necessita do auxílio dos credores, é possível que esses não confiem nos administradores que conduziram o devedor à crise econômico-financeira e, consequentemente, tornem-se menos cooperativos. Neste caso, a manutenção dos administradores mostra-se mais eficaz nos sistemas onde os credores exercem ativa supervisão da gestão do devedor.

E conclui o Banco Mundial que, não obstante a existência de regras deficientes de governança corporativa nos países em desenvolvimento, é mais eficaz o sistema no qual os administradores do devedor são mantidos no exercício de suas funções, sob a fiscalização judicial, podendo, contudo, os administradores vir a ser substituídos se constatada a prática de atos de improbidade ou que comprovem a incompetência para o exercício da função ${ }^{52}$.

\footnotetext{
52 "This decision is more complicated in a rehabilitation proceeding, where salvaging the business is the ultimate goal. In such cases, insolvency laws invest governance responsibilities in incumbent managers who retain control, or in an independent administrator who exercises all of the rights and duties of management, or combine the two approaches, retaining existing management but appointing na independent person to supervise and, if necessary, replace management. Displacing management from the outset, except in circumstances that warrant it, can cause damage and result in repercussions detrimental to the operation of the business at a critical juncture in its survival. In a genuine rehabilitation effort, replacing or sharply curtailing the powers of management could create a disincentive for incumbent management to seek rehabilitation when necessary, which would be counter-productive to policies supporting director and officer liability for wrong fultrading. On the other hand, creditors may have little or no confidence in management, and allowing management to continue in its capacity without appropriate checks and balances on its powers may make creditors less cooperative, which is vital to developing a rehabilitation plan that creditors will support. While some systems adopt this approach, it works best where management has express duties to the creditors who exercise active supervision over the process (such as, in the United States). Weaknesses in governance rules and institutional capacity suggest that the more practical approach in developing countries is to appoint and independent supervisor to work as a liais on between management and creditors,
} 
E esta é exatamente a posição adotada pela legislação brasileira, como alerta MUNHOZ (2007, p. 309), "ao manter o devedor e seus administradores na condução dos negócios durante a recuperação, sob a fiscalização do comitê de credores e do administrador judicial, admitindo, por outro lado, o seu afastamento pelo juiz em determinadas hipóteses, o art. 64 segue a orientação adotada na maioria dos países."

\section{Alemanha}

O processo de insolvência na Alemanha é regido pela Insolvenzodnung, InsO, de 5.10.1994, que entrou em vigor apenas em $1^{\circ} .1 .1999$, após longo período de vacatio legis que, segundo CEREZETTI (2012, p. 130), impunha-se em virtude das profundas modificações implementadas pela nova lei, que unificou a legislação concursal (pois as antigas Alemanha Ocidental e Oriental possuíam leis distintas regendo os processos de insolvência) e, fundamentalmente, porque as empresas da antiga Alemanha Oriental não tinham ainda sido privatizadas.

appointing an independent administrator where management is clearly unfit or has engaged in improper conduct. As indicated in the principle, however, independent administrators and supervisors are themselves held accountable to the same standards as management; they should be subject to removal for malfeasance or incompetence." (Tradução livre: Esta decisão é mais difícil nos processos de recuperação, onde o objetivo final é salvar o negócio. Nesses casos, as leis de falência investem na responsabilização dos administradores mantidos na gestão e dos administradores independentes, que exercem todos os direitos e deveres de gestão, ou combinam as duas abordagens, mantendo a gestão existente, mas nomeando pessoa independente para supervisionar e, se necessário, substituir os administradores. A substituição dos administradores desde o início, exceto em circunstâncias que a justifiquem, pode causar danos e resultar em repercussões negativas para o funcionamento do negócio em um momento crítico para sua sobrevivência. Em um verdadeiro esforço de recuperação, a substituição dos administradores ou a drástica redução dos poderes de gestão poderia criar um desincentivo para os administradores buscarem a recuperação quando necessário, o que seria contraprodutivo para as políticas de responsabilização dos administradores que agirem de modo inadequado. Por outro lado, os credores podem ter pouca ou nenhuma confiança na gestão, e a manutenção dos gestores sem freios e contrapesos adequados sobre seus poderes pode fazer os credores menos cooperativos, o que é vital para o sucesso de um plano de recuperação que os credores deverão apoiar. Enquanto alguns sistemas adota essa abordagem, ele funciona melhor onde os gestores têm deveres expressos para com os credores que exercem supervisão ativa sobre o processo (como nos Estados Unidos). Regras de governança deficientes e a incapacidade institucional sugerem que a abordagem mais prática nos países em desenvolvimento é a de nomear supervisor independente para trabalhar entre a administração e os credores, nomeando um administrador independente nos casos onde a gestão é claramente imprópria ou tenha se envolvido em conduta imprópria. Como indicado no princípio, no entanto, os administradores e supervisores independentes são eles próprios responsabilizados com os mesmos padrões que os administradores, e devem ser substituídos no caso de improbidade ou incompetência). 
Estabelecendo como objetivo do processo de insolvência a satisfação dos interesses dos credores, a Ins $O$ dispõe $\left(\operatorname{art.} 1^{\circ}\right)^{53}$ que essa meta pode ser atingida tanto mediante a realização dos ativos do devedor e o rateio do produto auferido entre os credores, quanto através de um plano de insolvência que conserve a empresa (NEGRÃO, 2010, p. 54), competindo aos credores, em reunião, não em assembleia (COROTTO, 2009, p. 83), decidir o modo pelo qual o procedimento de insolvência prosseguirá.

Isto porque, a legislação Alemã unificou a primeira fase do procedimento de insolvência, que se inicia a pedido do próprio devedor (nos casos de inadimplência - art. 17, ameaça de inadimplência - art. 18, ou insolvência - art. 19) ou dos credores (nas hipóteses de inadimplência ou insolvência - arts. 17 e 19), e que culmina com a realização de reunião de credores que, segundo COROTTO (2009, p. 83), decide o prosseguimento dos atos processuais.

Como o principal interesse a ser protegido é o dos credores, mesmo no caso de o próprio devedor ter apresentado o pedido de insolvência (autoconfissão), acompanhado do competente plano, os credores podem aprovar outro modo de realização do ativo, e até mesmo atribuir ao administrador da insolvência o encargo de elaborar novo plano, definindo o seu conteúdo, plano esse que deverá ser objeto de futura deliberação dos credores, desta vez reunidos em assembleia ${ }^{54}$.

\footnotetext{
53 " 1 Ziele des Insolvenzverfahrens - Das Insolvenzverfahren dient dazu, die Gläubiger eines Schuldners gemeinschaftlich zu befriedigen, indem das Vermögen des Schuldners verwertet und der Erlös verteilt oder in einem Insolvenzplan eine abweichende Regelung insbesondere zum Erhalt des Unternehmens getroffen wird. Dem redlichen Schuldner wird Gelegenheit gegeben, sich von seinen restlichen Verbindlichkeiten zu befreien."

Tradução de BERGER (2001, p. 219): "§ 1 Objetivos do processo de insolvência. O processo de insolvência tem por objetivo satisfazer coletivamente os credores de um devedor mediante a realização do patrimônio e o rateio do produto resultante e/ou mediante um plano de insolvência cujo conteúdo pode divergir das regras desta lei, especialmente visando a manutenção da empresa. Ao devedor honesto será concedida a oportunidade de exonerar-se de suas obrigações residuais."

${ }^{54}$ CEREZETTI (2012, p. 135) salienta que "o processo concursal alemão é unitário, ou seja, trata-se de um processo de insolvência no qual os credores decidirão, em determinado momento, se ele redundará na conservação da empresa (nos termos de um Sanierungsplan), na transferência da atividade a terceiro (de acordo com um Übertragunsplan) ou na liquidação do ativo (em consonância com um Liquidationsplan)". No mesmo sentido, NEGRÃO (2010, p. 55) destaca que o plano de insolvência, se "promovido por empresário ou sociedade empresária pode ser apresentado sob três modalidades: (a) plano de saneamento (Sanierungsplan); (b) plano de liquidação (Liquidationplan), que consiste na 'manutenção temporária da empresa e posterior liquidação ou venda dos bens que integram o patrimônio da massa'; (c) plano de transferência total ou parcial do patrimônio da empresa (Ubertragungsplan)."
} 
O plano de insolvência não pode ser apresentado pelos credores, mas apenas pelo devedor e pelo administrador da insolvência, plano esse objeto de exame de admissibilidade pelo juiz ${ }^{55} \mathrm{e}$, superada essa fase, levado à deliberação pelos credores em assembleia, na qual hipótese, se apresentado pelo administrador da insolvência, deverá contar com anuência do devedor.

Eventual oposição do devedor, contudo, será irrelevante se, cumulativamente, a situação dele não for pior do que seria no processo regular, e nenhum credor receber valor maior que o de seu crédito original (COROTTO, 2009, p. 111).

Desde a abertura do processo de insolvência, o devedor, em geral, é afastado da gestão de seus bens e de seu patrimônio, gestão essa que é atribuída ao administrador da insolvência (art. 80, $1^{\mathrm{a}}$ parte $^{56}$, cc art. $148,1^{\mathrm{a}}$ parte $^{57}$ ), nomeado pelos credores em assembleia geral.

Analisando a natureza jurídica da função do administrador de insolvência, COROTTO (2009, p. 169) informa que

desenvolveram-se, especialmente, três teorias: a Organyheorie, para a qual a sua atuação ocorre como órgão de representação da massa; a Vertretungstheorie, que visualiza o administrador da insolvência como representante do devedor; e a Amtstheorie, que o vê como exercente de

\footnotetext{
${ }^{55}$ COROTTO (2009, p. 99) esclarece que o juiz pode rejeitar de ofício o plano de insolvência "se constatar uma das hipóteses do § $231 \mathrm{I} \mathrm{n}^{\circ} 1$ a 3: 1 - se as prescrições legais quanto à apresentação e ao conteúdo não foram observadas e se a irregularidade não puder ser sanada ou não puder ser sanada dentro de um prazo ‘adequado' fixado pelo juízo; 2 - quando for evidente que o plano do devedor não tem nenhuma perspectiva de ser aprovado pelos credores ou de ser homologado judicialmente, ou; 3 - quando for evidente que as pretensões dos participantes, resultantes da parte organizatória do plano do devedor, não puderem ser cumpridas."

${ }^{56} \S 80$ Übergang des Verwaltungs- und Verfügungsrechts - (1) Durch die Eröffnung des Insolvenzverfahrens geht das Recht des Schuldners, das zur Insolvenzmasse gehörende Vermögen zu verwalten und über es zu verfügen, auf den Insolvenzverwalter über.
}

Tradução de BERGER (2001, p. 253): “§ 80 Transferência do direito de administração e de disposição (1) Com a abertura do processo de insolvência, o direito do devedor de administrar e de dispor sobre os bens pertencentes à massa insolvente serão transferidos ao administrador da insolvência."

57 § 148 Übernahme der Insolvenzmasse - (1) Nach der Eröffnung des Insolvenzverfahrens hat der Insolvenzverwalter das gesamte zur Insolvenzmasse gehörende Vermögen sofort in Besitz und Verwaltung zu nehmen.

Tradução de BERGER (2001, p. 288): “§ 148 Guarda dos bens da massa insolvente (1) Após a abertura do processo de insolvência, o administrador da insolvência deverá imediatamente arrecadar e administrar todo o patrimônio pertencente à massa insolvente." 
uma função judiciária. A Organyheorie parte do pressuposto de que a massa tem personalidade jurídica e, assim, ela seria representada pelo administrador da insolvência. No entanto, esse entendimento não supera o fato de que o devedor continua proprietário ( $\$ 80 \mathrm{I}$ ), e, por isso, a massa não pode ser sujeito de direito. Já a Vertretungstheorie visualiza o administrador da insolvência como representante legal forçado do devedor com poderes de representação restritos para a massa. A versão mais atualizada da teoria (neue Vertretungstheorie) sustenta que o administrador seria, na insolvência da pessoa jurídica, o seu órgão de representação. No entanto essa teoria não prospera porque o administrador da insolvência deve atender principalmente os interesses dos credores diante da finalidade legislativa impressa pelo $\S 1$ frase 1 . Além disso, a sua atuação é autônoma, respondendo pessoalmente por seus atos (§ 60 I). A Teoria da Função Judiciária (Amstheorie) tem prevalecido em relação às outras. Essa teoria sustenta que o administrador da insolvência atua em nome próprio como titular de um cargo privado no processo de insolvência. No âmbito processual, enquanto nas duas primeiras teorias o administrador da insolvência atuaria como representante, ele atua para a Teoria da Função Judiciária como 'parte de ofício' nos processos a favor dos interesses da massa. O administrador da insolvência pode fazer valer os direitos do devedor em virtude do direito de disposição que lhe é transferido em nome próprio por ocasião da abertura. ${ }^{58}$

Somente em casos excepcionais é que o devedor permanece na administração da empresa. Para tanto, ele deverá requerer, antes da abertura da insolvência, expressa autorização judicial. Após a abertura da insolvência, apenas os credores é que podem pedir ao juiz a manutenção do devedor na administração. $O$ deferimento do pedido (quer apresentado pelo devedor, quer formulado pelos credores) depende da apuração de que a manutenção do devedor não atrasará o curso do processo nem causará prejuízos aos credores (COROTTO, 2009, p. 157).

Examinando a possibilidade de o devedor ser mantido na administração de seus bens, visto que ele não foi capaz de evitar a insolvência, BERGER (2001, p. 106) ressalta que a experiência e o conhecimento que o devedor tem de seu negócio não podem ser desprezados, e seu afastamento implicará gastos e demandará tempo para que o administrador da insolvência se inteire dos negócios.

Se o devedor é mantido na gestão da empresa, seus atos são fiscalizados por um comissário, a quem a Ins $O$ atribui funções sem grande relevância, podendo o juiz, a pedido dos credores, estabelecer que determinados atos, para serem praticados

${ }^{58}$ Ver também, BERGER (2001, p. 102). 
validamente, dependam da anuência do administrador da insolvência (BERGER, 2001, p. 108). O comissário, assim, não tem participação efetiva nos negócios do devedor.

Acrescente-se, por outro lado, que, antes mesmo da declaração da insolvência, pode o juiz nomear administrador judicial provisório (ou interino), cujas funções são delimitadas no ato de sua nomeação, e podem variar desde simples acompanhamento da gestão da empresa, até a própria administração do patrimônio do devedor ${ }^{59}{ }_{-}^{60}$.

$59 \S 22$ Rechtsstellung des vorläufigen Insolvenzverwalters (1) Wird ein vorläufiger Insolvenzverwalter bestellt und dem Schuldner ein allgemeines Verfügungsverbot auferlegt, so geht die Verwaltungs- und Verfügungsbefugnis über das Vermögen des Schuldners auf den vorläufigen Insolvenzverwalter über. In diesem Fall hat der vorläufige Insolvenzverwalter: 1. das Vermögen des Schuldners zu sichern und zu erhalten; 2. ein Unternehmen, das der Schuldner betreibt, bis zur Entscheidung über die Eröffnung des Insolvenzverfahrens fortzuführen, soweit nicht das Insolvenzgericht einer Stillegung zustimmt, um eine erhebliche Verminderung des Vermögens zu vermeiden; 3. zu prüfen, ob das Vermögen des Schuldners die Kosten des Verfahrens decken wird; das Gericht kann ihn zusätzlich beauftragen, als Sachverständiger zu prüfen, ob ein Eröffnungsgrund vorliegt und welche Aussichten für eine Fortführung des Unternehmens des Schuldners bestehen. (2) Wird ein vorläufiger Insolvenzverwalter bestellt, ohne daß dem Schuldner ein allgemeines Verfügungsverbot auferlegt wird, so bestimmt das Gericht die Pflichten des vorläufigen Insolvenzverwalters. Sie dürfen nicht über die Pflichten nach Absatz 1 Satz 2 hinausgehen. (3) Der vorläufige Insolvenzverwalter ist berechtigt, die Geschäftsräume des Schuldners zu betreten und dort Nachforschungen anzustellen. Der Schuldner hat dem vorläufigen Insolvenzverwalter Einsicht in seine Bücher und Geschäftspapiere zu gestatten. Er hat ihm alle erforderlichen Auskünfte zu erteilen und ihn bei der Erfüllung seiner Aufgaben zu unterstützen; die $\S$ 97, 98, 101 Abs. 1 Satz 1, 2, Abs. 2 gelten entsprechend.

Tradução de BERGER (2001, p. 229): "§ 22 Competência legal do administrador interino da insolvência. (1) Tendo sido nomeado um administrador interino de insolvência e imposto ao devedor uma proibição geral para dispor, este direito e o de administrar o patrimônio do devedor será transferido para o administrador interino da insolvência. Neste caso, administrador interino da insolvência deverá: 1. Assegurar e conservar o patrimônio do devedor; 2. Até a decisão final sobre a abertura do processo de insolvência, dar continuidade as atividades da empresa, contando que o juízo da insolvência não tenha entendido melhor a paralisação das mesmas com fins de evitar significativa redução do patrimônio; 3. Examinar se o patrimônio do devedor cobre os custos do processo; o juízo poderá também ordenar ao administrador verificar, na condição de perito, se há uma razão legal de abertura e quais são as perspectivas de continuação das atividades da empresa. (2) Tendo sido nomeado um administrador interino de insolvência, sem que seja imposto ao devedor uma proibição geral para dispor, o juízo deverá determinar as obrigações do administrador interino de insolvência. Tais obrigações não deve exceder as obrigações estipuladas no inciso (1), segunda frase. (3) O administrador interino de insolvência está autorizado a entrar nas instalações de empresa e realizar investigações no local. O devedor deverá permitir ao administrador interino de insolvência examinar seus livros e documentação de negócios. O devedor deverá prestar ao administrador as informações necessárias; aplicam-se os $\S \S 97,98$, 101 , inciso (1), primeira e segunda frases, e inciso (2) analogicamente."

${ }^{60}$ Comentando sobre as funções do administrador provisório (ou interino), BERGER (2001, p. 101) salienta: “a, se o juiz decidir que o devedor não pode mais administrar os seus bens, essa função passa a ser do administrador interino. Compete-lhe então: zelar pela conservação dos bens do devedor, tomar as medidas necessárias para que os mesmos não se deteriorem e/ou sejam furtados (parág. $1^{\circ}, \mathrm{n}^{\circ} 1$, art. 22, InsO); dar continuidade aos negócios do devedor (parág. $1^{\circ}, \mathrm{n}^{\circ} 2$, art. 22, InsO); examinar se o patrimônio do devedor é suficiente para o pagamento das custas processuais (parág. $1^{\circ}, \mathrm{n}^{\mathrm{o}} 3$, art. 22 , InsO); dar continuidade aos litígios pendentes relacionados ao patrimônio da massa (art. 24, $\mathrm{n}^{\circ} 2$ InsO; art. $24 \mathrm{ZPO}$ ); atuar no feito como perito, se designado pelo juiz, com o objetivo de elaborar um parecer que esclareça se a fundamentação legal da ação corresponde à real situação econômica do devedor, assim como examinar a possibilidade de continuação das atividades do devedor (parág. $1^{\circ}, \mathrm{n}^{\mathrm{o}} 3$, art. 22, InsO); b. se o juiz decidir que o devedor pode continuar na administração de seus bens, deve então enumerar as funções do administrador interino. Exemplos: examinar se o patrimônio do devedor é suficiente para o pagamento das custas processuais (parág. $1^{\mathrm{o}}, \mathrm{n}^{\mathrm{o}} 3$, art. 22, 
Analisando as alterações legislativas implementadas na Alemanha, PUGLIESI (2013, p. 94) destaca que aquele país, apesar de privilegiar a satisfação dos interesses dos credores, reconhece a "realidade de que a 'empresa', enquanto atividade, representa um valor a ser tutelado", tanto que recente alteração legislativa, de $1^{\circ} .3 .2012$, buscando facilitar a reestruturação de negócios em atividade, autorizou a inclusão em planos de insolvência de previsão, por exemplo,

(i) que possibilite ao devedor permanecer em atividade como 'going concern'; (ii) que facilite a conversão de créditos em participação societária; (iii) transferência de participação societária para credores; (iv) que permita a redução do capital social e posterior aumento pela emissão de novas ações (ou quotas), com a finalidade de absorção de perdas de capital.

E especificamente em relação à administração do devedor, para que não se retarde a apresentação do pedido de reestruturação,

se o devedor tomar a iniciativa do pedido de insolvência e requerer que seja mantido na condução dos negócios, no período entre a abertura e a decretação da insolvência, poderá lhe ser concedido um prazo (de até três meses) no qual possa apresentar um plano de insolvência (PUGLIESI, 2013, p. 94).

2. Portugal

O processo de insolvência das empresas em dificuldade é regido em Portugal pelo Decreto-lei n ${ }^{\circ}$ 53/2004, de 18 de março, conhecido como Código da Insolvência ou da Recuperação de Empresas - CIRE, o qual, apesar de ter menos de dez anos de vigência, já sofreu inúmeras alterações, destacando-se as implementadas pelo Decreto-lei no 200/2004, de 18 de agosto, Decreto-lei no 282/2007, de 7 de agosto, Decreto-lei $n^{\circ}$ 76-A/2006, de 29 de março, Decreto-lei no 185/2009, de 12 de agosto, Decreto-lei n. ${ }^{\circ}$ 116/2008, de 4 de Julho e Lei no 16/2012, de 20 de abril.

InsO); conceder anuência ou não administrador interino quanto à disposição de bens que integrem o patrimônio da massa (parág. $2^{\circ}, \mathrm{n}^{\circ} 2$, art. 21, InsO). Independente do devedor continuar ou não na administração de seus bens, o administrador interino tem o direito de visitar o seu estabelecimento comercial, examinar livros e documentos necessários ao esclarecimento da ação de insolvência (parág. 3, art. 22, InsO).” 
A recente legislação portuguesa, inspirando-se na experiência da Alemanha ${ }^{61}$, unificou o procedimento de insolvência, em cujo curso os credores têm a possibilidade de deliberar se o patrimônio do devedor será liquidado para a satisfação de seus créditos, ou de aprovar plano que permita a reestruturação da empresa e, neste último caso, transferindo ou não sua titularidade a terceiros.

E de modo idêntico à legislação alemã, a primeira parte do art. $1^{\circ}$ do CIRE dispõe expressamente que a finalidade do processo de insolvência é a satisfação dos interesses dos credores, quer mediante a recuperação da empresa devedora, quer através da liquidação do patrimônio do devedor e sua partilha entre os credores ${ }^{62}$.

A opção legislativa portuguesa de priorizar o interesse dos credores, segundo o relatório do XV Governo Constitucional, justifica-se porque

O objectivo precípuo de qualquer processo de insolvência é a satisfação, pela forma mais eficiente possível, dos direitos dos credores. Quem intervém no tráfego jurídico, e especialmente quando aí exerce uma actividade comercial, assume por esse motivo indeclináveis deveres, à cabeça deles o de honrar os compromissos assumidos. A vida económica e empresarial é vida de interdependência, pelo que o incumprimento por parte de certos agentes repercute-se necessariamente na situação económica e financeira dos demais. Urge, portanto, dotar estes dos meios idóneos para fazer face à insolvência dos seus devedores, enquanto impossibilidade de pontualmente cumprir obrigações vencidas.

Sendo a garantia comum dos créditos o património do devedor, é aos credores que cumpre decidir quanto à melhor efectivação dessa garantia, e é por essa via que, seguramente, melhor se satisfaz o interesse público da preservação do bom funcionamento do mercado.

Quando na massa insolvente esteja compreendida uma empresa que não gerou os entendimentos necessários ao cumprimento das suas obrigações, a melhor satisfação dos credores pode passar tanto pelo encerramento da empresa, como pela sua manutenção em actividade. Mas é sempre da

${ }^{61}$ O relatório do XV Governo Constitucional, que aprovou o Decreto-lei no 53/2004, afirma textualmente em seu item $n^{\circ} 5$ que " Os sistemas jurídicos congéneres do nosso têm vindo a unificar os diferentes procedimentos que aí também existiam num único processo de insolvência, com uma tramitação supletiva baseada na liquidação do património do devedor e a atribuição aos credores da possibilidade de aprovarem um plano que se afaste deste regime, quer provendo à realização da liquidação em moldes distintos, quer reestruturando a empresa, mantendo-a ou não na titularidade do devedor insolvente. É o caso da recente lei alemã e da reforma do direito falimentar italiano em curso."

${ }^{62}$ Dispõe o item $n^{\circ} 1$ do art. $1^{\circ}$ do CIRE: “O 1 - O processo de insolvência é um processo de execução universal que tem como finalidade a satisfação dos credores pela forma prevista num plano de insolvência, baseado, nomeadamente, na recuperação da empresa compreendida na massa insolvente, ou, quando tal não se afigure possível, na liquidação do património do devedor insolvente e a repartição do produto obtido pelos credores." 
estimativa dos credores que deve depender, em última análise, a decisão de recuperar a empresa, e em que termos, nomeadamente quanto à sua manutenção na titularidade do devedor insolvente ou na de outrem. E, repise-se, essa estimativa será sempre a melhor forma de realização do interesse público de regulação do mercado, mantendo em funcionamento as empresas viáveis e expurgando dele as que o não sejam (ainda que, nesta última hipótese, a inviabilidade possa resultar apenas do facto de os credores não verem interesse na continuação). Entende-se que a situação não corresponde necessariamente a uma falha do mercado e que os mecanismos próprios deste conduzem a melhores resultados do que intervenções autoritárias. Ao direito da insolvência compete a tarefa de regular juridicamente a eliminação ou a reorganização financeira de uma empresa segundo uma lógica de mercado, devolvendo o papel central aos credores, convertidos, por força da insolvência, em proprietários económicos da empresa.

Para atingir a finalidade de assegurar o interesse dos credores, dispõe a CIRE que a insolvência deve ser requerida pelo devedor (art. 18) ${ }^{63}$, mas também pode ser pedido por qualquer credor (art. 20) e até mesmo pelo Ministério Público (art. 20). Na primeira etapa do procedimento, que culmina com a declaração ou não da insolvência, o devedor é mantido na administração da empresa, salvo se houver fundado receio da prática de atos de má gestão, na qual hipótese podem ser ordenadas medidas cautelares que visem impedir o agravamento da situação patrimonial, entre as quais a nomeação de um administrador judicial provisório (art. 31) com poderes exclusivos para a administração do patrimônio do devedor, ou para assistir o devedor nessa administração ${ }^{64}$.

${ }^{63}$ O relatório do XV Governo Constitucional, que aprovou o Decreto-lei $n^{\circ} 53 / 2004$, destaca em seu item $n^{\circ}$ 13 que "uma das causas de insucesso de muitos processos de recuperação ou de falência residiu no seu tardio início, seja porque o devedor não era suficientemente penalizado pela não atempada apresentação, seja porque os credores são negligentes no requerimento de providências de recuperação ou de declaração de falência, por falta dos convenientes estímulos. Uma lei da insolvência é tanto melhor quanto mais contribuir para maximizar ex post o valor do património do devedor sem por essa via constituir ex ante um estímulo para um comportamento negligente. Com o intuito de promover o cumprimento do dever de apresentação à insolvência, que obriga o devedor pessoa colectiva ou pessoa singular titular de empresa a requerer a declaração da sua insolvência dentro dos 60 dias seguintes à data em que teve, ou devesse ter, conhecimento da situação de insolvência, estabelece-se presunção de culpa grave dos administradores, de direito ou de facto, responsáveis pelo incumprimento daquele dever, para efeitos da qualificação desta como culposa."

${ }^{64} \mathrm{O}$ art. 33 da CIRE dispõe serem as seguintes as "Competências do administrador judicial provisório: 1 - O administrador judicial provisório a quem forem atribuídos poderes exclusivos de administração do património do devedor deve providenciar pela manutenção e preservação desse património, e pela continuidade da exploração da empresa, salvo se considerar que a suspensão da actividade é mais vantajosa para os interesses dos credores e tal medida for autorizada pelo juiz. 2 - O juiz fixa os deveres e as competências do administrador judicial provisório encarregado apenas de assistir o devedor na administração do seu património, devendo: a) Especificar os actos que não podem ser praticados pelo devedor sem a aprovação do administrador judicial provisório; ou b) Indicar serem eles genericamente todos os que envolvam a alienação ou a oneração de quaisquer bens ou a assunção de novas responsabilidades que não sejam indispensáveis à gestão corrente da empresa. 3 - Em qualquer das hipóteses previstas nos números anteriores, o administrador judicial provisório tem o direito de acesso à sede e às instalações empresariais do devedor e de proceder a quaisquer inspecções e a exames, designadamente dos elementos da sua contabilidade, e o devedor fica obri- 
A regra geral, assim, é que até a sentença que decreta a insolvência, o devedor é mantido na administração da empresa e, somente excepcionalmente ele é afastado e substituído pelo administrador judicial provisório.

O inverso ocorre, porém, após a decretação da insolvência, pois neste caso o devedor é afastado da gestão de seus bens e patrimônio, a qual é atribuída, com exclusividade, ao administrador judicial nomeado pelo juiz. Apenas excepcionalmente é que o devedor é mantido na administração. Com efeito, na sentença que decreta a insolvência o juiz nomeia o administrador judicial (art. 36, letra “d”, e art. 52, no 1) a partir de lista oficial de administradores de insolvência (art. 32, no 1), atribuindo-se-lhe, entre outras, as seguintes funções (art. 55):

(a) preparar o pagamento das dívidas do insolvente à custa das quantias em dinheiro existentes na massa insolvente, designadamente das que constituem produto da alienação, que lhe incumbe promover, dos bens que a integram; e (b) prover, no entretanto, à conservação e frutificação dos direitos do insolvente e à continuação da exploração da empresa, se for o caso, evitando quanto possível o agravamento da sua situação econômica.

Acrescenta o art. 81 da CIRE que a declaração de insolvência priva o devedor dos poderes de administração e de disposição dos bens integrantes da massa insolvente, poderes esses que são conferidos ao administrador da insolvência, a quem não se aplicam eventuais limitações ao poder de disposição do devedor estabelecidas por decisão judicial ou administrativa, ou impostas por lei apenas em favor de pessoas determinadas.

Exatamente por essa razão, o administrador da insolvência assume também a representação do devedor para todos os efeitos patrimoniais, com exceção da representação do devedor no âmbito do próprio processo de insolvência, seus incidentes e apensos, salvo expressa disposição em contrário.

gado a fornecer-lhe todas as informações necessárias ao desempenho das suas funções, aplicando-se, com as devidas adaptações, o artigo 83." 
Embora essa seja a regra geral (afastamento do devedor e gestão da empresa pelo administrador da insolvência) ${ }^{65}$, o juiz pode manter o devedor na administração da empresa, desde que sejam preenchidos os requisitos fixados nos itens 2 e 3 do art. 224 da CIRE, a saber:

2 - São pressupostos da decisão referida no número anterior que: a) $O$ devedor a tenha requerido; b) O devedor tenha já apresentado, ou se comprometa a fazê-lo no prazo de 30 dias após a sentença de declaração de insolvência, um plano de insolvência que preveja a continuidade da exploração da empresa por si próprio; c) Não haja razões para recear atrasos na marcha do processo ou outras desvantagens para os credores; d) O requerente da insolvência dê o seu acordo, caso não seja o devedor. 3 - A administração é também confiada ao devedor se este o tiver requerido e assim o deliberarem os credores na assembleia de apreciação de relatório ou em assembleia que a preceda, independentemente da verificação dos pressupostos previstos nas alínea c) e d) do número anterior, contando-se o prazo previsto na alínea b) do mesmo número a partir da deliberação dos credores. ${ }^{66}$

\begin{abstract}
Acrescente-se ainda que na hipótese de o devedor ser mantido na administração da empresa insolvente, a gestão será fiscalizada pelo administrador da insolvência, que comunicará imediatamente ao juiz e à comissão de credores quaisquer
\end{abstract}

${ }^{65} \mathrm{O}$ item n ${ }^{\circ} 32$ do relatório do XV Governo Constitucional, que aprovou o Decreto-lei $\mathrm{n}^{\circ}$ 53/2004, acrescenta que "o principal efeito sobre o devedor, aliás clássico, é o da privação dos poderes de administração e de disposição dos bens integrantes da massa insolvente, por si ou pelos seus administradores, passando tais poderes a competir ao administrador da insolvência. Consagra-se, porém, a possibilidade de o devedor se manter na administração da massa insolvente nos casos em que esta integre uma empresa. Essa manutenção pressupõe, entre outros aspectos, que o devedor a tenha requerido, tendo já apresentado, ou comprometendose a fazê-lo dentro de certo prazo, um plano de insolvência que preveja a continuidade da exploração da empresa por si próprio, e ainda que conte com a anuência do credor requerente ou da assembleia de credores. Fica bem à vista o sentido deste regime: não obrigar à privação dos poderes de administração do devedor, em concreto quanto à empresa de que seja titular, quando se reconheça que a sua aptidão empresarial não é prejudicada pela situação de insolvência, a qual pode até resultar de factores exógenos à empresa, havendo, simultaneamente, a convicção de que a recuperação da empresa nas suas mãos permitirá uma melhor satisfação dos créditos do que a sua sujeição ao regime comum de liquidação."

66 Comentando a respeito da administração do devedor insolvente na legislação portuguesa, PUGLIESI (2013, p. 103) destaca que "em contrapartida, vale lembrar que como efeito da declaração de insolvência, o devedor foi desapossado de seus bens e, como consequência, perdeu o direito de administrá-los. Os poderes de administração da massa insolvente passam, assim, desde logo, ao administrador da insolvência (art. 81, n. $1^{\circ}$ ), que os exercerá com a colaboração da comissão de credores (se instaurada, art. 55, n. 1) e sob a fiscalização do juiz (art. 58), até a deliberação a respeito da continuidade ou do encerramento da atividade. Portanto, a administração da massa insolvente, pelo devedor, ocorre em caráter de exceção e somente de dará se, cumulativamente, concorrerem as seguintes condições (arts. 36, alínea "e", e 223): (i) existência de empresa (conforme conceito expresso no art. $5^{\circ}$ do CIRE); (ii) requerimento expresso do devedor; (iii) apresentação de um plano de insolvência pelo devedor, ou comprometimento de apresentá-lo, no prazo legal; (iv) manifestação de concordância do credor que tenha requerido a instauração do procedimento concursal; (v) inexistência de razões para recear atrasos no processo ou outras desvantagens para os credores (art. 224, n. 02, alínea 'c')." 
ocorrências que desaconselhem a manutenção do devedor na condução do negócio (art. 226).

Isso não obstante, ainda que se tratem de atos normais de gestão, o devedor não pode contrair obrigações se houver oposição do administrador da insolvência. E se se tratar de atos extraordinários de gestão, sua prática depende de consentimento do administrador da insolvência. Ademais, pode também o juiz proibir a prática de determinados atos pelo insolvente, administrado pelo devedor, sem a aprovação do administrador da insolvência. Por fim, o administrador da insolvência pode exigir que fiquem a seu cargo todos os recebimentos em dinheiro e todos os pagamentos que devam ser efetuados pelo insolvente (art. 226).

Em suma, decretada a insolvência, o administrador da insolvência é quem administrará o patrimônio do devedor, sendo que, se for conveniente para evitar a crise econômica, administrará a continuação da atividade econômica. Isso não obstante, os órgãos sociais do devedor mantêm-se em funcionamento após a declaração de insolvência (art. 82), mas sem qualquer poder de gestão.

Destaque-se ainda que, dada a finalidade da CIRE de privilegiar os interesses dos credores, podem eles, reunidos em assembleia, deliberar a substituição do administrador da insolvência escolhido pelo juiz, por outro eleito no próprio conclave, o qual não precisa sequer estar inscrito na lista oficial de administradores da insolvência (art. 53), acrescentando o item $\mathrm{n}^{\mathrm{o}} 3$ do referido art. 53 que "o juiz só pode deixar de nomear como administrador da insolvência a pessoa eleita pelos credores, em substituição do administrador em funções, se considerar que a mesma não tem idoneidade ou aptidão para o exercício do cargo, que é manifestamente excessiva a retribuição aprovada pelos credores ou, quando se trate de pessoa não inscrita na lista oficial, que não se verifica nenhuma das circunstâncias previstas no número anterior."

Em outras palavras, aos credores compete não apenas deliberar a respeito da liquidação do patrimônio do devedor para satisfação de seus créditos ou a aprovação de plano de reestruturação com ou sem a transferência do controle a terceiros, como ainda lhes atribuiu a CIRE competência para escolher o administrador da insolvência, que, se 
entender conveniente, administrará a empresa insolvente até a realização da assembleia de credores.

Recente alteração legislativa implementada pela Lei nº 16/2012, de 20 de abril, incluiu os arts. 17-A a 17-I na CIRE e instituiu o processo especial de revitalização que, tem caráter urgente, e "destina-se a permitir ao devedor que, comprovadamente, se encontre em situação económica difícil ${ }^{67}$ ou em situação de insolvência meramente iminente, mas que ainda seja suscetível de recuperação, estabelecer negociações com os respetivos credores de modo a concluir com estes acordo conducente à sua revitalização" (item $n^{\circ} 1$ do art. 17-A).

O processo especial de revitalização inicia-se pela manifestação de vontade do devedor e de, pelo menos, um dos seus credores, por meio de declaração escrita, de realizarem negociações visando a revitalização daquele por meio da aprovação de um plano de recuperação (art. 17-C).

Obtida a aprovação do plano de revitalização pela unanimidade dos credores, o devedor o apresentará para homologação judicial (art. 17-F, item no 1). Se o plano de revitalização, porém, não contar com a aprovação de todos os credores, ele será apresentado para aprovação judicial. Na hipótese de não aprovação do plano, se o devedor não estiver em situação de insolvência, o processo especial de revitalização será extinto. Entretanto, se a situação for de insolvência, o juiz a decretará e o processo seguirá o procedimento regular da insolvência (arts. 17-F e 17-G).

No processo especial de revitalização, a apresentação do pedido não acarreta o afastamento do devedor da gestão da empresa, mas ele fica impedido de praticar atos de “especial relevo" sem prévia autorização do administrador judicial provisório, atos esses expressamente indicados no art. 161 da CIRE $^{68}$ e que incluem, entre outras, a transferência da empresa.

${ }^{67} \mathrm{O}$ art. 17-B da CIRE define que: "para efeitos do presente Código, encontra-se em situação económica difícil o devedor que enfrentar dificuldade séria para cumprir pontualmente as suas obrigações, designadamente por ter falta de liquidez ou por não conseguir obter crédito."

${ }^{68}$ CIRE, art. 161: "1 - Depende do consentimento da comissão de credores, ou, se esta não existir, da assembleia de credores, a prática de actos jurídicos que assumam especial relevo para o processo de insolvência. 2 $\mathrm{Na}$ qualificação de um acto como de especial relevo atende-se aos riscos envolvidos e às suas repercussões 
O procedimento concursal é regido na Espanha pela Ley no 22/2003, de 9 de julho, conhecida como Ley Concursal, que teve o mérito de unificar não apenas a legislação falimentar, que até então era regulado por diversas leis esparsas, inclusive alguns dispositivos do Código Comercial de 30.5.1829, mas também unificar o procedimento $^{69}$, aplicável tanto para pessoas naturais quanto jurídicas ${ }^{70}$.

E o procedimento único, ressalta a Exposição de Motivos da Ley no 22/2003, é possível em virtude da flexibilidade da Lei de Concursos, que permite sua adequação a diversas situações e soluções, através das quais se pode alcançar a satisfação dos credores, finalidade essencial do concurso $^{71}$. Daí que o objetivo primordial da lei concursal espanhola é satisfazer o interesse dos credores e, se for possível, preservar a empresa.

Tanto assim é que, como destaca NEGRÃO (2010, p. 71), ao promulgar a Ley Concursal, o governo da Espanha destacou que

sobre a tramitação ulterior do processo, às perspectivas de satisfação dos credores da insolvência e à susceptibilidade de recuperação da empresa. 3 - Constituem, designadamente, actos de especial relevo: a) A venda da empresa, de estabelecimentos ou da totalidade das existências; b) A alienação de bens necessários à continuação da exploração da empresa, anteriormente ao respectivo encerramento; c) A alienação de participações noutras sociedades destinadas a garantir o estabelecimento com estas de uma relação duradoura; d) A aquisição de imóveis; e) A celebração de novos contratos de execução duradoura; f) A assunção de obrigações de terceiros e a constituição de garantias; g) A alienação de qualquer bem da empresa por preço igual ou superior a (euro) 10.000 e que represente, pelo menos, $10 \%$ do valor da massa insolvente, tal como existente à data da declaração da insolvência, salvo se se tratar de bens do activo circulante ou for fácil a sua substituição por outro da mesma natureza sem prévia autorização do administrador judicial provisório."

${ }^{69}$ Exposição de Motivos: La ley opta por los principios de unidad legal, de disciplina y de sistema.

Tradução livre: A lei opta pelos princícios de unidade legal, de disciplina e de sistemas.

${ }^{70}$ Art. $1^{\circ}$. Presupuesto subjetivo. 1. La declaración de concurso procederá respecto de cualquier deudor, sea persona natural o jurídica. 2. El concurso de la herencia podrá declararse en tanto no haya sido aceptada pura y simplemente. 3. No podrán ser declaradas en concurso las entidades que integran la organización territorial del Estado, los organismos públicos y demás entes de derecho público.

Tradução livre: Pressuposto subjetivo: 1. A declaração do concurso pode referir-se a qualquer devedor, pessoa natural ou jurídica. 2. O concurso da herança poderá ser declarada enquanto não tiver sido aceita pura e simplesmente. 3. Não poderão ser declarados em concurso as entidades que integram a organização do Estado, os órgãos públicos e demais entidades de direito público.

${ }^{71}$ No original: "La unidad del procedimiento de concurso se consegue en virtud de la flexibilidad de que la ley lo dota, que permite su adecuación a diversas situaciones y soluciones, a través de las cuales puede alcanzarse la satisfacción de los acreedores, finalidad esencial del concurso." 
a finalidade da conservação da atividade profissional ou empresarial do devedor submetido ao concurso pode cumprir-se por meio de um convênio, cuja proposta deve ser acompanhada de um plano de viabilidade. Ainda que o objeto do concurso não seja o saneamento de empresas, um convênio destinado à continuação da atividade pode salvar as que se considerem total ou parcialmente viáveis, em benefício não só dos credores, mas do próprio devedor, dos trabalhadores e de outros interessados. O relatório obrigatório da administração concursal é mais uma garantia dessa solução ${ }^{72}$.

O procedimento único é composto de duas fases distintas. A primeira, denominada concurso, é comum e pode ser instaurada tanto a pedido do próprio devedor (caso em que o concurso será voluntário) quanto a requerimento de credores (hipótese na qual o concurso será necessário $)^{73}$. O concurso não tem como efeito imediato a interrupção das atividades do devedor, pois nesta etapa, que culminará na liquidação ou na aprovação do convênio, apenas são nomeados os órgãos que atuarão no processo e são adotadas condutas visando a apuração do ativo e do passivo, formando-se o quadro geral de credores (PUGLIESI, 2013, p. 111).

A segunda etapa do procedimento, como destaca a Exposição de Motivos da Ley $\mathrm{n}^{\mathrm{o}}$ 22/2003 son el convenio y la liquidación para cuya respectiva tramitación se articulan específicas fases en el procedimiento. El convenio es la solución normal del concurso, que la ley fomenta con una serie de medidas, orientadas a alcanzar la satisfacción de los acreedores a través del acuerdo contenido en un negocio jurídico en el

\footnotetext{
${ }^{72}$ Na nota de rodapé $\mathrm{n}^{\circ} 30$, NEGRÃO (2010, p. 72) traz a redação original do texto do governo da Espanha: "La finalidad de conservación de la actividad professional ou empresarial del concursado puede cumplirse a través de un convenio, a cuya propuesta se acompañará un plan de viabilidade. Aunque el objeto no sea el saneamento de empresas, un convenio de continuación puede ser instrumento para salvar las que se consideren total o parcialmente viables, en beneficio no sólo de los acreedores, sino del proprio concursado, de los trabajadores y de otros intereses. El informe preceptivo de la administración concursal es una garantía más de esta solución."

73 "Artículo 3. Legitimación. 1. Para solicitar la declaración de concurso están legitimados el deudor y cualquiera de sus acreedores. Si el deudor fuera persona jurídica, será competente para decidir sobre la solicitud el órgano de administración o de liquidación. 2. Por excepción a lo dispuesto en el apartado anterior, no está legitimado el acreedor que, dentro de los seis meses anteriores a la presentación de la solicitud, hubiera adquirido el crédito por actos ínter vivos y a título singular, después de su vencimiento. (...)"

Tradução livre: Art. $3^{\circ}$ Legitimação. 1 Para requerer a declaração de concurso estão legitimados o devedor e qualquer de seus credores. Se o devedor for pessoa jurídica, será competente para decidir sobre o requerimento o órgão da administração ou liquidação. 2. Com exceção ao disposto no item anterior, não tem legitimidade o credor que, nos seis meses que antecederam o pedido de abertura do concurso tiver adquirido o crédito por ato entre vivos, a título singular, depois de seu vencimento (...).
} 
que la autonomía de la voluntad de las partes goza de uma gran amplitud ${ }^{74}$. Não aprovada a proposta de convênio, a segunda fase do procedimento único será a liquidação do devedor.

Especificamente em relação à administração do devedor, a Ley no 22/2003 dispõe, nos quatro primeiros itens de seu art. 40, que se se tratar de concurso voluntário, o devedor conserva a administração de seus bens e de seu patrimônio, mas se se tratar de concurso necessário, o devedor é afastado da administração e substituído pelos administradores concursais. Isso não obstante, em decisão fundamentada, poderá o juiz, no concurso necessário, manter o devedor na administração de seus bens e, no concurso voluntário, afastar o devedor da administração, substituindo-o pelos administradores concursais $^{75}$. Acrescente-se, ainda, que mesmo no caso de o devedor ser afastado da gestão dos bens e do patrimônio, tratando-se de pessoa jurídica, seus órgãos de administração não são extintos, mas apenas lhe são suprimidos os poderes de gestão ${ }^{76}$.

\footnotetext{
${ }^{74}$ Tradução livre: São o convênio e a liquidação, para cujos respectivos trâmites se estabelecem fases específicas no procedimento. O convênio é a solução normal do concurso, que a lei fomenta com uma série de medidas, orientadas a alcançar a satisfação dos credores por acordo contido em negócio jurídico onde a autonomia da vontade das partes tem grande amplitude.

75 “Artículo 40. Facultades patrimoniales del deudor. 1. En caso de concurso voluntario, el deudor conservará las facultades de administración y disposición sobre su patrimonio, quedando sometido el ejercicio de éstas a la intervención de los administradores concursales, mediante su autorización o conformidad. 2. En caso de concurso necesario, se suspenderá el ejercicio por el deudor de las facultades de administración y disposición sobre su patrimonio, siendo sustituido por los administradores concursales. 3. No obstante lo dispuesto en los apartados anteriores, el juez podrá acordar la suspensión en caso de concurso voluntario o la mera intervención cuando se trate de concurso necesario. En ambos casos, deberá motivarse el acuerdo señalando los riesgos que se pretendan evitar y las ventajas que se quieran obtener. 4. A solicitud de la administración concursal y oído el concursado, el juez, mediante auto, podrá acordar en cualquier momento el cambio de las situaciones de intervención o de suspensión de las facultades del deudor sobre su patrimonio. Al cambio de las situaciones de intervención o de suspensión y a la consiguiente modificación de las facultades de la administración concursal se dará la misma publicidad que, conforme a los artículos 23 y 24, se hubiera dado a la declaración de concurso."
}

Tradução livre: Art. 40. Faculdades patrimoniais do devedor. 1. No caso de concurso voluntário, o devedor conservará a administração e a faculdade de disposição de seu patrimônio, submetendo-se porém seu exercício à intervenção dos administradores concursais, mediante autorização ou anuência. 2. No caso de concurso necessário, o devedor será suspenso do exercício das faculdades de administração e disposição de seu patrimônio, sendo substituído pelos administradores concursais. 3. Não obstante o disposto nos itens anteriores, o juiz poderá adotar a suspensão no concurso voluntário ou a mera intervenção no concurso necessário. Em ambos os casos, a decisão deverá ser motivada, assinalando os riscos que se pretendem evitar e as vantagens que se querem obter. 4. A requerimento dos administradores concursais e ouvido o devedor, o juiz, por decisão, poderá adotar em qualquer momento a troca das situações de intervenção ou de suspensão das faculdades do devedor sobre seu patrimônio. À troca das situações de intervenção e de suspensão e a consequente modificação das faculdades dos administradores concursais se dará a mesma publicidade que, nos termos dos arts. 23 e 24 , se tiver dado à declaração de concurso.

${ }^{76}$ A parte inicial do item $\mathrm{n}^{\circ} 1$ do art. 48 da Ley Concursal dispõe que durante la tramitación del concurso, se mantendrán los órganos de la persona jurídica deudora, sin perjuicio de los efectos que sobre su funcionamento produzca la intervención o la suspensión de sus facultades de administración y disposición y salvo el 
E a razão dessa distinção do tratamento dispensado ao devedor que requer o concurso ou que tem o pedido formulado pelo credor é explicada pela Exposição de Motivos da Ley Concursal: el sistema legal combina así las garantías del deudor con la conveniencia de adelantar en el tiempo la declaración de concurso, a fin de evitar que el deterioro del estado patrimonial impida o dificulte las soluciones más adecuadas para satisfacer a los acreedores. Los estímulos a la solicitud de concurso voluntario [...] son medidas con las que se pretende alcanzar ese objetivo ${ }^{77}$. Em outras palavras, a manutenção do devedor na administração dos bens, no caso de concurso voluntário, é um incentivo para que ele não atrase o pedido, e seu afastamento, no caso de concurso necessário, é uma penalidade pela demora.

Sendo o devedor afastado, a administração dos bens será exercida pelos administradores concursais, os quais são integrados (a) por um advogado com mais de cinco anos de experiência, (b) um auditor, economista ou administrador com mais de cinco anos de experiência e (c) por um credor quirografário ou com privilégio geral sem garantia $^{78}$.

supuesto en que, a consecuencia de la apertura de la fase de liquidación, se declare el cese de los administradores o liquidadores.

Tradução livre: durante a tramitação do concurso, serão mantidos os órgãos da pessoa jurídica devedora, sem prejuízo dos efeitos sobre seu funcionamento produza a intervenção ou a suspensão de suas faculdades de administração e disposição e salvo a consequência da eventual fase de liquidação, que destitui os administradores e liquidantes.

77 Tradução livre: o sistema legal combina as garantias do devedor com a conveniência de se antecipar o tempo da declaração do concurso, a fim de evitar que a deterioração de seu estado patrimonial impeça ou dificulte as soluções mais adequadas para satisfazer os credores. Os estímulos ao requerimento do concurso voluntário [...] são medidas com as quais se pretende alcançar esse objetivo.

78 “Artículo 27. Condiciones subjetivas para el nombramiento de administradores concursales. 1. La administración concursal estará integrada por los siguientes miembros: $1^{\circ}$. Un abogado con experiencia profesional de, al menos, cinco años de ejercicio efectivo. $2^{\circ}$. Un auditor de cuentas, economista o titulado mercantil colegiados, con una experiencia profesional de, al menos, cinco años de ejercicio efectivo. $3^{\circ}$. Un acreedor que sea titular de un crédito ordinário o con privilegio general, que no esté garantizado. El juez. procederá al nombramiento tan pronto como le conste la existencia de acreedores en quienes concurran esas condiciones. Cuando el acreedor designado administrador concursal sea una persona jurídica, designará, conforme al procedimiento previsto en el apartado 3 de este artículo, un profesional que reúna las condiciones previstas en el párrafo $2^{\circ}$ anterior, el cual estará sometido al mismo régimen de incapacidades, incompatibilidades y prohibiciones que los demás miembros de la administración concursal. En caso de que el acreedor designado administrador concursal sea una persona natural en quien no concurra la condición de auditor de cuentas, economista o titulado mercantil colegiado, podrá participar en la administración concursal o designar un profesional que reúna las condiciones previstas en el párrafo $2^{\circ}$ anterior, siguiendo para ello el procedimiento previsto en el apartado 3 de este artículo, quedando sometido el profesional así designado al mismo régimen de incapacidades, incompatibilidades, prohibiciones y remuneración que los demás miembros de la administración concursal." 
Encerrada a fase do concurso, se a proposta de convênio for aprovada e homologada por sentença, todos os efeitos do concurso cessarão, de modo que, se o devedor tiver sido afastado da administração e substituído pelos administradores concursais, ele será reconduzido, salvo disposição em sentido contrário no próprio convênio $^{79}$.

Entretanto, se o convênio não for aprovado, será decretada a liquidação do devedor, o que, se se tratar de pessoa jurídica, importará em sua dissolução, substituindo-se os administradores nomeados na forma do contrato ou estatuto social (ou liquidantes) pelos administradores concursais ${ }^{80}$.

Tradução livre: Condições subjetivas para a nomeação dos administradores concursais. 1. A administração concursal será integrada pelos seguintes membros: $1^{\circ}$ um advogado com experiência profissional de, no mínimo, cinco anos de exercício efetivo. $2^{\circ}$. Um contador, economista ou administrador de empresas com experiência profissional de, no mínimo, cinco anos de exercício efetivo. $3^{\circ}$ um credor que seja titular de crédito quirografário ou com privilégio geral, sem garantias. O juiz procederá à nomeação tão logo tome conhecimento da existência de credores que preencham esses requisitos. Quando o credor nomeado administrador concursal for pessoa jurídica designará, nos termos do procedimento constante do item 3 deste artigo, um profissional que preencha os requisitos previstos no parágrafo $2^{\circ}$ supra, o qual estará sujeito ao mesmo regime de incapacidade, incompatibilidade e proibições que os demais membros da administração concursal. No caso do credor nomeado administrador concursal ser pessoa natural que não seja contador, economista ou administrador de empresas, ele poderá participar da administração concursal ou nomear um profissional que preencha os requisitos previstos no parágrafo $2^{\circ}$ supra, seguindo para tanto o procedimento constante do item 3 deste artigo, submetendo-se o profissional assim nomeado ao mesmo regime de incapacidade, incompatibilidade, proibições e remuneração que os demais membros da administração concursal.

79 "Artículo 133. Comienzo y alcance de la eficacia del convenio. 1. El convenio adquirirá plena eficacia desde la fecha de la sentencia de su aprobación, salvo que, recurrida ésta, quede afectado por las consecuencias del acuerdo de suspensión que, en su caso, adopte el juez conforme a lo dispuesto en el apartado 5 del artículo 197. 2. Desde la eficacia del convenio cesarán todos los efectos de la declaración de concurso, quedando sustituidos por los que, en su caso, se establezcan en el propio convenio y sin perjuicio de los deberes generales que para el deudor establece el artículo 42. Asimismo, cesarán en su cargo los administradores concursales, sin perjuicio de las funciones que el convenio pudiese encomendar a todos o alguno de ellos hasta su íntegro cumplimiento y de lo previsto en el capítulo II del título VI. Producido el cese, los administradores concursales rendirán cuentas de su actuación ante el juez del concurso, dentro del plazo que éste señale."

Tradução livre: Art. 133. Termo inicial e alcance da eficácia do convênio. 1. O convênio terá plena eficácia desde a data da sentença de sua aprovação, salvo se, interposto recurso, este afetar as consequências do acordo de suspensão que, no caso, o juiz adotar conforme o disposto no item 5 do art. 197. 2. Desde o termo inicial da eficácia do convênio, cessarão todos os efeitos da declaração do concurso, os quais serão substituídos pelos que vierem estabelecidos no convênio, sem prejuízo dos deveres gerais estabelecidos ao devedor no art. 42. Do mesmo modo, serão extintos os administradores concursais, sem prejuízo das funções que o convênio estabeleça a todos ou alguns de seus membros, até o integral cumprimento e do previsto no capítulo II do Título VI. Extinto, os administradores concursais prestarão contas de seus atos ao juiz do concurso, no prazo que ele fixar.

80 "Artículo 145. Efectos sobre el concursado. 1. La situación del concursado durante la fase de liquidación será la de suspensión del ejercicio de las facultades de administración y disposición sobre su patrimonio, con todos los efectos establecidos para ella en el título III de la presente Ley. Cuando en virtud de la eficacia del convenio, y conforme a lo previsto en el apartado 2 del artículo 133, los administradores concursales hubieren cesado, el juez, acordada que haya sido la apertura de la liquidación, los repondrá en el ejercicio 
4. Argentina

Como anota NEGRÃO (2010, p. 63), “a atual legislação argentina é fruto da reforma entre 1995 e 2002, a partir da promulgação da Ley de Concursos y Quiebras (n. 24.522, de 20 de julho de 1995 - LCQ) e das subsequentes Leyes n. 25.563 e 25.589, de 15 de fevereiro e 16 de maio de 2002, respectivamente, que a alteraram, sobretudo quanto ao capítulo do acordo preventivo e à ampliação dos poderes judiciais na homologação do plano."

Esta Lei $\mathrm{n}^{\circ}$ 24.522/95, além de regular o processo de falência (quiebra) estabelece dois institutos de que podem se valer os devedores em crise para superar as dificuldades, quais sejam, o concurso preventivo e o acordo preventivo extrajudicial.

Segundo destaca ROUILLON (2012, p. 186),

bajo el régimen legal argentino actual la reorganización empresarial a que venimos haciendo referencia puede intentarse y lograrse por dos vías: a) informalmente, mediante los acuerdos preconcursales (simples, no homologables o no homologados) regidos por la legislación ordinaria $o$ contratual (con los alcances y efectos arriba explicados), $y \quad b$ ) formalmente, a través del concurso preventivo regulado por el art. $5^{\circ}$ y ss., o del concurso preventivo abreviado reglado por el art. 69 y ss. de la $L C Q .{ }^{81}$

de su cargo o nombrará a otros. (...) 3. Si el concursado fuese persona jurídica, la resolución judicial que abra la fase de liquidación contendrá la declaración de disolución si no estuviese acordada y, en todo caso, el cese de los administradores o liquidadores, que serán sustituidos por la administración concursal para proceder de conformidad con lo establecido en esta Ley."

Tradução livre: Art. 145. Efeitos sobre o devedor. 1. A situação do devedor durante a fase de liquidação será de suspensão do exercício das faculdades de administração e disposição de seu patrimônio, com todos os efeitos estabelecidos no título III desta lei. Quando, em virtude da eficácia do convênio, nos termos do item $\mathrm{n}^{\mathrm{o}} 2$ do art. 133, os administradores concursais tiveram sido extintos, o juiz, decretada a liquidação, os reconduzirá ao exercício do cargo ou nomeará outros. (...) 3. Se o devedor for pessoa jurídica, a decisão judicial que instaura a fase de liquidação declarará a dissolução, se ela não estiver prevista e, em todo caso, a destituição dos administradores ou liquidantes, que serão substituídos pelos administradores concursais que procederão nos termos estabelecidos nesta lei.

81 Tradução livre: no regime legal argentino atual, a reorganização empresarial a que viemos fazendo referência pode ser intentada e efetivada por dois meios: a) informalmente, mediante os acordos pré-concursais (simples, não homologáveis ou não homologados) regidos pela legislação ordinária ou contratual (com os alcances e efeitos acima explicados), e b) formalmente, pelo concurso preventivo regulado pelo art. $5^{\circ}$ e seguintes, ou pelo concurso preventivo abreviado, regulado pelo art. 69 e seguintes da LCQ. 
Acrescentando o autor (2012, p. 36) que, historicamente, a falência antecedeu os procedimentos postos à disposição dos devedores insolventes para o pagamento dos credores sem a liquidação forçada do patrimônio dos devedores. Estes procedimentos, cuja finalidade é prevenir a falência, permitem que o devedor reorganize seu passivo e solucione as causas da crise empresarial, razão pela qual têm sido denominados de "reorganização". A lei da Argentina, porém, manteve a nomenclatura tradicional: concurso preventivo.

O concurso preventivo consiste, fundamentalmente, na aprovação pelos credores de um plano de reorganização apresentado pelo devedor, sendo que somente ele, devedor, não os credores, tem legitimidade para requerer sua abertura ${ }^{82}$.

O pedido do concurso preventivo tem como principal efeito, especificamente em relação à condução dos negócios, a manutenção do devedor como administrador do patrimônio, nos termos do art. $15^{\circ}$ da Lei $n^{\circ}$ 24.522/1995: El concursado conserva la administración de su patrimônio bajo la vigilância del síndico ${ }^{83}$. Daí que, diferentemente do que ocorre na falência, no concurso preventivo o devedor conserva a administração de seu patrimônio.

E a situação era exatamente a mesma na legislação concursal anterior Argentina. De fato, a Lei $\mathrm{n}^{\mathrm{o}}$ 24.522/1995 (LCQ) revogou a anterior Lei $\mathrm{n}^{\circ} 19.551$, de 4.4.1972 (que foi alterada pelas Leis $\mathrm{n}^{\mathrm{o}} 22.917$, de 27.4.1983, e $\mathrm{n}^{\mathrm{o}} 22.985$, de 25.11.1983), cujas normas relativas à administração do devedor que pede a abertura de concurso preventivo eram rigorosamente as mesmas da atual legislação.

\footnotetext{
82 “Art. $5^{\circ}$ Pueden solicitar la formación de su concurso preventivo las personas compreendidas em el art. $2^{\circ}$, incluidas las de existencia ideal em liquidación."

Tradução livre: Art. $5^{\circ}$ Podem requerer a formação do concurso preventivo as pessoas compreendidas no art. $2^{\circ}$, inclusive as pessoas jurídicas em liquidação.

"Art. $2^{\circ}$ Pueden ser declaradas en concurso las personas de existencia visible, las de existencia ideal de carácter privado y aquellas sociedades em las que el Estado nacional, provincial o municipal sea parte, cualquiera sea el porcentaje de su participación."

Tradução livre: Podem ser declaradas em concurso as pessoas físicas, as pessoas jurídicas privas e as sociedades nas quais a União, os Estados ou os Municípios sejam sócios, qualquer que seja a participação.

${ }^{83}$ Tradução livre: Art. 15. O devedor conserva a administração de seu patrimônio sob a fiscalização do síndico.
} 
O pedido de abertura do concurso, assim, não importa no afastamento do devedor ou seus administradores, destacando ARGERI (1972, p. 259), em comentário à lei anterior, que a manutenção do devedor como gestor de seus bens se justifica pelo interesse de manutenção da atividade empresarial: ao gerir o negócio, o devedor age não apenas no próprio interesse de resguardar seu patrimônio, mas também no interesse de toda a economia $^{84}$.

Tanto assim é que, ao apresentar o projeto que acabou sendo convertido na atual LCQ, expressamente consignou-se:

En lo que se refere a la iniciativa exclusiva a cargo del deudor, también se há considerado la inconveniencia de permitir que, por vontade de terceros ajenos, el deudor se encuentre obligado a ingresar a un proceso de características universales, donde deberá continuar manteniendo la administración normal de sus bienes, aunque con las restriciones previstas en las normas pertinentes.

[...] Por otra parte, la experiencia ha indicado que en aquelles casos donde terceros ajenos a la empresa asumen la administración en forma temporaria e abrupta, los resultados, generalmente, en procesos tan complejos y de profunda crisis, solamente, derivan en mayores costos y una pérdida de rentabilidad, a más de demorar, innecesariamente, la conclusión del processo ${ }^{85}$ (ROUILLON, 2012, p. 421)

${ }^{84}$ BARAVALLE e GRANADOS (1995, p. 76), nos comentários à atual LCQ, citam decisão do Tribunal de Santa Fé, proferida na vigência da anterior lei de falências, onde se consigna: "La apertura del concurso preventivo no produce efecto impeditivo del pago de un cheque entregado con anterioridade o posterioridade a esa declaración. Ello es así porque el concursado conserva la administración de su patrimoio bajo la vigilancia del síndico (art. 16 ley 19.551 - ADLA, XXXII-B, 1836-) y puede realizar aquellos actos que no excedan la administración ordinaria de su giro comercial com el propósito de proseguir la actividad normal del negocio que no es sólo el objetivo particular del peticionante sino de la propria ley que justamente persigue la regularización de la actividad económica para que la continuación de la empresa posibilite superar la crisis (C. Penal Santa Fe, Sala III, marzo 18 - 1982 - B, C.A.) La Ley, 1983-C, 603 - ED, 100-331).”

Tradução livre: A abertura do concurso preventivo não tem como efeito impedir o pagamento de cheque emitido antes ou depois da declaração. Isto é assim porque o devedor conserva a administração de seu patrimônio sob a fiscalização do síndico (art. 16 ley 19.551 - ADLA, XXXII-B, 1836-) e pode realizar os atos que não excedam a administração ordinária de sua atividade comercial com o propósito de prosseguir a atividade normal do negócio, que não é somente o objetivo particular do devedor, mas da própria lei, que justamente visa a regularização da atividade econômica, para que a continuação da empresa permita superar a crise (C. Penal Santa Fe, Sala III, marzo 18 - 1982 - B, C.A.) La Ley, 1983-C, 603 - ED, 100-331).

85 Tradução livre: Em relação iniciativa exclusiva do devedor, também deve ser considerado a inconveniência de se permitir que, pela vontade de terceiros alheios, o devedor se encontre obrigado a ingressar em processo de características universais, motivo pelo qual deve ser mantido na administração normal de seus bens, ainda que com as restrições previstas nas normas pertinentes. [...] De outro lado, a experiência tem mostrado que naqueles casos onde terceiros alheios à empresa assumem a administração de forma temporária e abrupta, os resultados, geralmente, em processos tão complexos e de profunda crise, somente resultam maiores custos e perda de rentabilidade, além de a conclusão do processo demorar desnecessariamente. 
Mas apesar de ser mantido na gestão da empresa, a lei impõe diversas restrições e proibições à atuação do devedor, as quais podem ser classificadas em três categorias: (a) atos proibidos, os quais são indicados no art. 16 da $\mathrm{LCQ}^{86}$; (b) atos sujeitos a autorizações, que também são enumerados no mesmo art. 16 da LCQ; e (c) atos que podem ser praticados livremente, mas sob a fiscalização do síndico, a saber, os atos ordinários de administração, que o devedor pratica livremente, visto que nem o síndico nem o juiz podem interferir na administração do devedor (ROUILLON, 2012, p. 37).

Os atos que o devedor está proibido de praticar estão indicados na parte inicial do referido art. 16 da Lei ${ }^{\circ}$ 24.522/1995 e consistem, fundamentalmente, nos atos a título gratuito ou que modifiquem a situação dos credores sujeitos ao concurso preventivo, porquanto, ressalta ROUILLON (2012, p. 80),

tende a hacer efectiva la pars condicio creditorum y por ello prohíbe que el deudor realice cualquier acto que altere la situación em que se hallaban los acreedores anteriores a la presentación em concurso, al tempo em que su deudor solicitó la formación de éste ( $p$. ej. la constitución de una garantía real a favor de un crédito quirografario anterior a la presentación; el pago de un acreedor anterior a la presentación; etcétera. $)^{87}$

86 “Art. 16.- (ACTOS PROHIBIDOS) El concursado no puede realizar actos a título gratuito o que importen alterar la situación de los acreedores por causa o título anterior a la presentación.

(ACTOS SUJETOS A AUTORIZACIÓN) Debe requerir previa autorización judicial para realizar cualquiera de los siguientes actos: los relacionados con bienes registrables; los de disposición o locación de fondos de comercio; los de emisión de debentures con garantía especial o flotante; los de emisión de obligaciones negociables con garantía especial o flotante; los de constitución de prenda y los que excedan de la administración ordinaria de su giro comercial.

La autorización se tramita con audiencia del síndico y del comité de control; para su otorgamiento el juez ha de ponderar la conveniencia para la continuación de las actividades del concursado y la protección de los intereses de los acreedores."

Tradução livre: Art. 16 -. (ATOS PROIBIDOS) O devedor não pode realizar atos gratuitos ou que alterem a situação dos credores anteriores à apresentação do concurso.

(ATOS SUJEITOS A AUTORIZAÇÃO) Requer prévia autorização judicial a realização de qualquer dos seguintes atos: aqueles relativos a bens registrados, a alienação ou locação de fundos de comércio; a emissão de debêntures com garantia especial ou flutuante; a emissão de títulos de obrigações negociáveis com garantia especial ou flutuante a constituição de renda e os que excedam a simples administração das atividades comerciais.

A autorização se processa com a manifestação do síndico e do comitê de credores; para sua concessão o juiz deverá apreciar a conveniência para a continuação das atividades do devedor e a proteção dos interesses dos credores.

87 Tradução livre: tem por finalidade tornar efetiva a pars condicio creditorum creditorum e por essa razão proíbe o devedor de praticar quaisquer atos que alterem a situação dos credores anteriores à abertura do concurso, no momento em que o devedor requereu sua formação (por exemplo, a constituição de garantia real em favor de crédito quirografário anterior ao concurso, o pagamento de credor anterior ao pedido de abertura do concurso; etc). 
E a parte final do mesmo dispositivo legal estabelece os atos cuja pratica pelo devedor dependem de autorização judicial, quais sejam, todos os atos que excedem a simples administração do negócio e que a lei expressamente não proíbe a prática (ROUILLON, 2012, p. 83).

Acrescenta o art. 17 da mesma Lei $\mathrm{n}^{\circ}$ 24.522/1995, por sua vez, as consequências de o devedor praticar os atos expressamente proibidos por lei (parte inicial do art. 16), ou sem a indispensável autorização judicial (parte final do art. 16):

Art. 17 (ACTOS INEFICACES). Los actos cumplidos en violación a lo dispuesto en el artículo 16 son ineficaces de pleno derecho respecto de los acreedores.

(SEPARACIÓN DE LA ADMINISTRACIÓN). Además, cuando el deudor contravenga lo establecido en los artículos 16 y 25 o cuando oculte bienes, omita las informaciones que el juez o el síndico le requieran, incurra en falsedad en las que produzca o realice algún acto en perjuicio evidente para los acreedores, el juez puede separarlo de la administración por auto fundado y designar reemplazante. Esta resolución es apelable al solo efecto devolutivo, por el deudor. Si se deniega la medida puede apelar el síndico. El administrador debe obrar según lo dispuesto en los artículos 15 y 16.

(LIMITACIÓN) De acuerdo con las circunstancias del caso, el juez puede limitar la medida a la designación de un coadministrador, un veedor o un interventor controlador, con las facultades que disponga. La providencia es apelable en las condiciones indicadas en el segundo párrafo.

En todos los casos, el deudor conserva en forma exclusiva la legitimación para obrar, en los actos del juicio que, según esta ley, correspondan al concursado. ${ }^{88}$

88 Tradução livre: (ATOS INEFICAZES) Os atos praticados com violação ao disposto no art. 16 são ineficazes de pleno direito em relação aos credores.

(DESTITUIÇÃO DA ADMINISTRAÇÃO). Ademais, se o devedor violar o disposto nos artigos 16 e 25, ocultar bens, omitir informações requeridas pelo juiz ou pelo síndico, dar informações falsas, ou praticar qualquer ato em prejuízo evidente para os credores, o juiz pode afastá-lo da administração por decisão fundamentada e nomear um substituto. O recurso do devedor contra esse decisão terá efeito apenas devolutivo. Se o pedido for negado o síndico poderá recorrer. O administrador deve agir segundo o que dispõem os artigos 15 e 16 .

(LIMITAÇÃO) De acordo com as circunstâncias do caso, o juiz pode limitar a medida à nomeação de um coadministrador, um fiscal ou um interventor controlador, com os poderes de que dispuser. A decisão é recorrível, nas condições estabelecidas no parágrafo segundo.

Em todos os casos, o devedor mantém de modo exclusivo legitimidade para agir, nos atos judiciais que, nos termos desta lei, sejam de competência do devedor. 
Desses dispositivos legais decorre que se o devedor praticar qualquer ato expressamente proibido pela lei (atos a título gratuito ou que modifiquem a situação dos credores sujeitos ao concurso preventivo), ou não autorizado pelo juiz (relativos a bens registrados, alienação ou locação de fundos de comércio, a emissão de debêntures com garantia especial ou flutuante, constituição de renda e os que excedem a simples administração), o ato será válido entre as partes, mas não terá eficácia em relação aos credores sujeitos ao concurso.

A segunda parte dessa norma estabelece que se for praticado qualquer ato proibido ou não autorizado, bem como se viajar ao exterior sem autorização judicial ${ }^{89}$, ocultar bens, omitir informações requeridas pelo juiz ou pelo síndico, dar informações falsas, ou praticar qualquer ato em prejuízo evidente para os credores, o devedor ou seus administradores podem ser afastados da gestão, hipótese na qual, dependendo da gravidade do ato praticado, será nomeado, pelo juiz, um coadministrador, um fiscal ou um interventor controlador, cujos poderes são fixados no ato de nomeação.

Assim como na atual a Lei $\mathrm{n}^{\mathrm{o}} 24.522 / 1995$, a revogada Lei $\mathrm{n}^{\mathrm{o}} 19.551$, de 4.4.1972, continha normas similares a respeito da administração do devedor que pedia a abertura de concurso, pois a prática de certos atos era proibida ou dependia de autorização judicial, sendo que os atos realizados com infração a essas normas eram válidos entre os contratantes, mas ineficazes em relação aos credores, e podiam, a critério do juiz, acarretar o afastamento do devedor da gestão, hipótese na qual era nomeado um coadministrador, um fiscal ou um interventor controlador, cujos poderes também eram delimitados pelo juiz $^{90}$.

89 “Art. 25 - (VIAJE AL EXTERIOR). El concursado y, en su caso, los administradores y socios con responsabilidad ilimitada de la sociedad concursada, no pueden viajar al exterior sin previa comunicación al juez del concurso, haciendo saber el plazo de la ausencia, el que no podrá ser superior a CUARENTA (40) días corridos. En caso de ausencia por plazos mayores, deberá requerir autorización judicial.”

Tradução livre: O devedor e, se for o caso, os administradores e os sócios de responsabilidade ilimitada do devedor não podem viajar ao exterior sem prévia comunicação ao juiz do concurso, comunicando o prazo de ausência, que não poderá ser superior a 40 dias corridos. No caso de ausência por prazos maiores, deverá ser requerida autorização judicial.

${ }^{90}$ A redação dos arts. 15,16 e 17 da atual Lei no 24.522/1995 é muito similar à dos arts. 16,17 e 18 da revogada Lei $n^{\circ} 19.551 / 1972$. 
A revogada Lei $n^{\circ}$ 19.551/1972, do mesmo modo que a atual LCQ, dispunha que a consequência da prática, pelo devedor, de atos proibidos ou sem a devida autorização judicial era a ineficácia, não sua nulidade, de modo que, na hipótese de aprovação do plano apresentado e seu cumprimento pelo devedor, os atos praticados com violação da LCQ tornam-se plenamente eficazes, independentemente de qualquer pronunciamento judicial (FASSI e GEBAHRDT, 1993, p. 75).

E além da ineficácia, a prática desses atos poderia acarretar o afastamento do devedor da gestão de seus bens, hipótese na qual o juiz, em decisão fundamentada, nomeava pessoa de sua confiança como coadministrador, fiscal ou interventor controlador, explicando FASSI e GEBAHRDT (1993, p. 76) $)^{91}$ :

COADMINISTRACIÓN. - Si es nombrado um coadministrador, éste deberá actuar em forma conjunta com el concursado, y las funciones de ambos quedan sujeitas igualmente a los arts, 16 y $17 .^{92}$

VEEDOR O INTERVENTOR CONTROLADOR - En estos casos la administración queda em manos del concursado, pero además de la vigilância del síndico, queda sometida a la del veedor o interventor controlador. Al hacer el nombramiento el juez determina las faculdades.

Acrescente-se ainda que, mesmo na hipótese de afastamento do devedor e nomeação do coadministrador, compete exclusivamente ao próprio devedor, devidamente presentado na forma de seu contrato ou estatuto social, praticar os atos judiciais relacionados ao processo de concurso preventivo (art. 17, parte final).

\section{França}

O Code de Commerce, com as diversas alterações implementadas nos últimos $\operatorname{anos}^{93}$, estabelece, como esclarece NEGRÃO (2010, p. 93), "três procedimentos de

\footnotetext{
${ }^{91}$ Tradução livre: CO-ADMINISTRADOR - se é nomeado um co-administrador, ele deverá atuar de modo conjunto com o devedor, e as funções de ambos ficam igualmente sujeitas aos arts. 16 e 17. GESTOR OU INTERVENTOR CONTROLADOR - Nestes casos a administração fica nas mãos do devedor, mas além da fiscalização do síndico, fica também submetida ao gestor e ao interventor controlador. Ao fazer a nomeação, o juiz fixa as faculdades.

${ }^{92}$ Os referidos arts. 16 e 17 são os da Lei ${ }^{\circ}$ 19.551/1972, que correspondem aos arts. 15 e 16 da atual Lei ${ }^{\circ}$ $24.522 / 1995$.

${ }^{93}$ As principais alterações no direito falimentar francês foram implementadas a partir da Lei 67-653, de 13 de julho de 1967, do decreto 67-1120, de 22 de dezembro de 1967, e da Ordenance 67-820, de 23 de setembro
} 
prevenção e tratamento das crises econômico-financeiras e outros dois de liquidação: (a) de prevenção: procédures de conciliation, de sauvegarde e de redressement; (b) de liquidação: procédures de liquidation e de liquidation simplifiée"

O procedimento conciliatório (“conciliacion”) está previsto no art. 611-4 do Code de Commerce, segundo o qual

Il est institué, devant le tribunal de commerce, une procédure de conciliation dont peuvent béneficier ler personnes exerçant une activité commerciale ou artisanale qui éprouvent une dificulte juridique, économique ou financière, avérée ou prévisible, et ne se trouvent pas em cessation des paiments depuis plus de quarante-cinq jours. ${ }^{95}$

Neste procedimento, que tem lugar perante o tribunal do comércio, cujo presidente nomeia um conciliador, o devedor que esteja, potencial ou efetivamente, em dificuldade jurídica, econômica ou financeira, cujo inadimplemento não seja superior a 45 dias, busca, por meio de negociação, acordo com seus credores com vistas a permitir a superação de sua crise. Por se tratar de meio negocial, o conciliador (“conciliateur") não substitui o devedor na gestão da empresa e não elabora plano de recuperação algum: sua função é propor soluções que permitam a conclusão de acordo entre o devedor e seus credores (PUGLIESE, 2013, p. 60), de sorte a preservar a atividade econômica e os empregos.

de 1967, que introduziram a separação da sorte da empresa da do empresário, de modo que eventual conduta reprovável do titular da empresa não acarreta, obrigatoriamente, a falência da empresa (CEREZETTI, 2012, p. 117). Posteriormente, como informa a mesma autora (2012, p. 118), o direito falimentar sofreu novas alterações, implementadas, fundamentalmente, "pela Lei 84-148, de 1.3.1984, que regula a prevenção e o règlement amiable de dificuldades empresariais, e pela Lei 85-88, de 25.1.1985, que cuida do redressement judiciaire e da liquidation judiciaire", bem como por inúmeras outras leis, tais como a Lei 85-89, que trata dos administradores judiciais, e dos Decretos 85-295, 85-1388 e 85-1389. Mais recentemente, novas alterações foram introduzidas em 1994, em 2005 e em 2008 (Ordennance 2008-1345, de 18 de dezembro de 2008 e o Décret 2009-160, de 12 de fevereiro de 2009).

${ }^{94}$ Além desses procedimentos, a lei francesa também prevê a possibilidade de o devedor requerer a nomeação de um mandataire ad hoc, cuja finalidade é auxiliá-lo na superação da crise financeira. "A natureza do mandat ad hoc é essencialmente contratual e nada poderá ser imposto aos credores: tudo deve ser aceito. Esse sistema de negociação envolve uma plasticidade tal que permite a sua adoção como medida paralela a uma conciliation ou mesmo a um procedimento de sauvegard ou redressement. O mandat ad hoc, outrossim, pode ser um eficiente prelúdio para futura conciliation" (PUGLIESE, 2013, p. 59).

${ }^{95}$ Tradução de NEGRÃO (2010, p. 94): "É instituído, perante o tribunal de comércio, um procedimento de conciliação do qual se podem beneficiar pessoas que exerçam uma atividade comercial ou artesanal e que enfrentam dificuldade jurídica, econômica ou financeira, verificada ou previsível, desde que não se encontrem em estado de cessação de pagamento por um período superior a quarenta e cinco dias." 
Alcançado acordo, terá ele eficácia apenas para os signatários, e poderá ser homologado judicialmente se o devedor demonstrar que (a) não está em estado de cessação de pagamentos; (b) o acordo será suficiente para que a empresa continue em atividade; e (c) os credores não signatários não serão prejudicados.

O procedimento de sauvegarde, por sua vez, foi introduzido na legislação da França com a reforma de 2005, e tem por objetivo, segundo dispõe o art. 620-1 do Code de Commerce $^{96}$, a reorganização da empresa com a finalidade de permitir a manutenção da atividade econômica a partir de plano aprovado. Neste procedimento, explicam FRANCO e SZTAJN (2008, p. 223),

implanta-se sistema de supervisão da atividade empresarial, realizado por pessoa independente (commissaires aux compptes) e perante um tribunal do comércio, do qual o próprio presidente é empresário e, desta forma, mais apto a apreciar o motivo da crise da empresa, induzindo o devedor para atuar para superar estas dificuldades.

O processo de salvaguarda é preventivo, pois é requerido pelo devedor que não se encontra em estado de cessação de pagamentos, ou seja, permite que o devedor em dificuldade, mas adimplente, requeira proteção judicial para superar a crise, pois a abertura do processo suspende as ações e execuções. Durante o período de observação de seis meses, prorrogável por igual período ${ }^{97}$, o devedor permanece sendo fiscalizado, devendo apresentar, e obter a aprovação, de "plano de salvaguarda" (CEREZETTI, 2012, p. 125).

\footnotetext{
${ }^{96}$ Art. 620-1: "Il est institué une procédure de sauvegarde ouverte sur demande d'un débiteur mentionné à l'article L. 620-2 qui, sans être en cessation des paiements, justifie de difficultés qu'il n'est pas en mesure de surmonter. Cette procédure est destinée à faciliter la réorganisation de l'entreprise afin de permettre la poursuite de l'activité économique, le maintien de l'emploi et l'apurement du passif. La procédure de sauvegarde donne lieu à un plan arrêté par jugement à l'issue d'une période d'observation et, le cas échéant, à la constitution de deux comités de créanciers, conformément aux dispositions des articles L. 626-29 et L. 62630."

Tradução livre: É instituído o procedimento de salvaguarda, que será aberto a pedido do devedor nos termos do art. L620-2, quando ele estiver em dificuldades que não possa superar e que possam conduzi-lo ao estado de insolvência. Este procedimento destina-se a facilitar a reorganização da empresa com a finalidade de permitir a continuação da atividade econômica, a manutenção dos empregos e a liquidação do passivo. O procedimento de salvaguarda dará lugar a um plano aprovado por decisão judicial depois de um período de observação e, se for o caso, a constituição de comitê de credores, de acordo com o disposto nos artigos L.626-29 e L.626-30.

97 “Art. L 621-3 - Le jugement ouvre une période d'observation d'une durée maximale de six mois qui peut être renouvelée une fois par décision motivée à la demande de l'administrateur, du débiteur ou du ministère public. Elle peut en outre être exceptionnellement prolongée à la demande du procureur de la République par décision motivée du tribunal pour une durée fixée par décret en Conseil d'Etat."
} 
Isto porque, neste procedimento, os administradores do devedor são mantidos na gestão da empresa, mas seus atos são fiscalizados pelo administrador judicial, cuja nomeação não é obrigatória (art. L 621-4) ${ }^{98}$, e que deve auxiliar os diretores do devedor, respeitando as funções que lhes competem (art. L 622-1) ${ }^{99}$. Porque o devedor não está

Tradução livre: A decisão judicial iniciará um período de observação que terá duração máxima de seis meses e que poderá ser renovado uma vez a pedido do administrador, do devedor ou do Ministério Público. Poderá também prorrogar-se excepcionalmente por período fixado por decreto do Conselho de Estado, a pedido do Fiscal da República, por decisão motivada do juiz.

${ }^{98}$ Art. L 621-4: “(...) Dans le même jugement, sans préjudice de la possibilité de nommer un ou plusieurs experts en vue d'une mission qu'il détermine, le tribunal désigne deux mandataires de justice qui sont le mandataire judiciaire et l'administrateur judiciaire, dont les fonctions sont respectivement définies à l'article L. 622-20 et à l'article L. 622-1. Il peut, à la demande du ministère public, désigner plusieurs mandataires judiciaires ou plusieurs administrateurs judiciaires. Toutefois, le tribunal n'est pas tenu de désigner un administrateur judiciaire lorsque la procédure est ouverte au bénéfice d'un débiteur dont le nombre de salariés et le chiffre d'affaires hors taxes sont inférieurs à des seuils fixés par décret en Conseil d'Etat. Dans ce cas, les dispositions du chapitre VII du présent titre sont applicables. Jusqu'au jugement arrêtant le plan, le tribunal peut, à la demande du débiteur, du mandataire judiciaire ou du ministère public, décider de nommer un administrateur judiciaire (...)"

Tradução livre: (...) Na mesma decisão, sem prejuízo da possibilidade de nomear um ou vários peritos para uma missão, o Tribunal nomeará dois mandatários judiciais cujas funções estão fixadas nos artigos 622-20 e 622-1. A pedido do Ministério Público, poderá nomear vários mandatários judiciais e vários administradores judiciais. No caso previsto no parágrafo quarto do artigo L621-1, o Ministério Público poderá se opor à nomeação da pessoa nomeada anterioremente como mandatário ad hoc ou conciliador no início do processo relativo ao mesmo devedor. Não obstante, o Tribunal só estará obrigado a nomear administrador judicial quando o procedimento tiver sido instaurado em benefício de pessoa cujo número de empregados e valor dos negócios antes dos impostos sejam inferiores aos montantes fixados por decreto do Conselho de Estado. Neste caso, aplicar-se-á o disposto no Capítulo VII deste Título. Até a decisão que aprovar o plano, a pedido do devedor, do mandatário judicial ou do Ministério Público, o Tribunal poderá decidir nomear administrador judicial (...)

${ }^{99}$ Art. L 622-1: "I.-L'administration de l'entreprise est assurée par son dirigeant. II.-Lorsque le tribunal, en application des dispositions de l'article L. 621-4, désigne un ou plusieurs administrateurs, il les charge ensemble ou séparément de surveiller le débiteur dans sa gestion ou de l'assister pour tous les actes de gestion ou pour certains d'entre eux. III.-Dans sa mission d'assistance, l'administrateur est tenu au respect des obligations légales et conventionnelles incombant au chef d'entreprise. IV.-A tout moment, le tribunal peut modifier la mission de l'administrateur sur la demande de celui-ci, du mandataire judiciaire ou du ministère public. V.-L'administrateur peut faire fonctionner sous sa signature les comptes bancaires ou postaux dont le débiteur est titulaire si ce dernier a fait l'objet des interdictions prévues aux articles 65-2 et 68, troisième alinéa, du décret du 30 octobre 1935 unifiant le droit en matière de chèques."

Tradução livre: I - A administração da empresa competirá a seus dirigentes. II - Na hipótese do disposto no artigo L.621-4, o Tribunal nomeará um ou vários administradores, a quem incumbirá, juntos ou separadamente, supervisionar o devedor e lhe ajudar em todos ou alguns atos de gestão. III - Na sua missão, o administrador está obrigado a respeitar as obrigações legais e convencionais que incumbem aos dirigentes do devedor. IV - O Tribunal poderá em todo momento alterar a missão do administrador a prequerimento deste, do mandatário judicial ou do Ministério Público. V - O administrador poderá gerir, com sua firma, as contas bancárias e postais de que o devedor era titular se a este tiverem sido impostas as inabilitações previstas nos artigos 65-2 e 68, parágrafo terceiro, do decreto de 30 de outubro de 1935 que unificou a legislação em matéria de cheques. 
inadimplente, ao devedor é permitido exercer todos os atos de disposição que não competirem ao administrador judicial (art. L 622-3) ${ }^{100}$.

O redressement judiciaire, ou recuperação judicial, por sua vez, está previsto no art. 631-1 do Code de Commerce ${ }^{101} \mathrm{e}$, assim como a sauvegarde, tem por finalidade permitir a manutenção da empresa e dos empregos. A diferença entre os procedimentos é que o redressement judiciaire pode ser requerido pelo devedor inadimplente, que cessou seus pagamentos, e está impossibilitado de quitar seu passivo exigível com seu ativo disponível (NEGRÃO, 2012, p. 94), ao contrário da salvaguarda, de que se vale o devedor em dificuldade, mas adimplente.

De modo idêntico ao procedimento de sauvegarde, no redressement há um período de observação de seis meses, prorrogável uma vez, no qual deve ser apresentado e aprovado plano de recuperação (art. L 631-7) ${ }^{102}$. Durante esse período, procura-se manter a atividade da empresa, porquanto a finalidade dos dois procedimentos é buscar solução para a crise do devedor.

${ }^{100}$ Art. L. 622-3: "Le débiteur continue à exercer sur son patrimoine les actes de disposition et d'administration, ainsi que les droits et actions qui ne sont pas compris dans la mission de l'administrateur. En outre, sous réserve des dispositions des articles L. 622-7 et L. 622-13, les actes de gestion courante qu'accomplit seul le débiteur sont réputés valables à l'égard des tiers de bonne foi."

Tradução livre: O devedor continuará exercendo sobre seu patrimônio os atos de disposição e de administração, assim como os direitos e ações que não estiverem incluídos na função do administrador. Ademais, não obstante as disposições dos artigos L.622-3 y L.621-13, os atos de gestão corrente que o devedor realize serão considerados válidos em relação aos terceiros de boa-fé.

${ }^{101}$ Art. L 631-1: "Il est institué une procédure de redressement judiciaire ouverte à tout débiteur mentionné aux articles L. 631-2 ou L. 631-3 qui, dans l'impossibilité de faire face au passif exigible avec son actif disponible, est en cessation des paiements. Le débiteur qui établit que les réserves de crédit ou les moratoires dont il bénéficie de la part de ses créanciers lui permettent de faire face au passif exigible avec son actif disponible n'est pas en cessation des paiements. La procédure de redressement judiciaire est destinée à permettre la poursuite de l'activité de l'entreprise, le maintien de l'emploi et l'apurement du passif. Elle donne lieu à un plan arrêté par jugement à l'issue d'une période d'observation et, le cas échéant, à la constitution de deux comités de créanciers, conformément aux dispositions des articles L. 626-29 et L. 626-30.”

Tradução livre: É instituído o procedimento de recuperação judicial a todo devedor indicado nos artigos L.631-2 ou L.631-3 que, na impossibilidade de pagar o passivo exigível com o ativo de que dispõe, encontrase em estado de cessação de pagamentos. $\mathrm{O}$ devedor que estabelecer reservas de crédito ou for beneficiário de moratórias que, concedidas por seus credores, lhe permitam pagar o passivo exigível com seu ativo disponível não se encontram em estado de insolvência. O procedimento de recuperação judicial destina-se a permitir a continuidade da atividade da empresa, a manutenção dos empregos e a liquidação do passivo. O procedimento de recuperação se fará com a aprovação judicial de um plano, após período de observação e, se for o caso, a constituição de dois comitês de credores, nos termos dos artigos L.626-29 e L.626-30.

${ }^{102}$ Art. L.631-7: “Les articles L. 621-1, L. 621-2 et L. 621-3 sont applicables à la procédure de redressement judiciaire"

Tradução livre: O disposto nos artigos L. 621-1, L. 621-2 e L. 621-3 aplicam-se ao procedimento de recuperção judicial. 
Na recuperação judicial, porém, embora os dirigentes do devedor sejam mantidos em seus cargos, as funções que exercerão na gestão da empresa serão fixadas judicialmente. Com efeito, no redressement a nomeação do administrador judicial é obrigatória, e o tribunal é que fixa suas funções, encarregando-o de auxiliar o devedor na gestão da empresa, podendo até mesmo atribuir-lhe, com exclusividade, total ou parcial, a própria condução dos negócios. Bem por isso, tanto a remuneração dos dirigentes do devedor, quanto a do administrador judicial são fixadas pelo tribunal (art. L.631-12) ${ }^{103}$.

Em suma, embora os processos de salvaguarda e de recuperação tenham por finalidade preservar a empresa e os empregos, PUGLIESI (2013, p. 65) ressalta que a diferença entre esses procedimentos reside no fato de que na salvaguarda, como o devedor não está inadimplente haverá menor interferência na gestão da empresa e o devedor conservará maior poder decisório. O princípio fundamental desses dois procedimentos é que, sendo mantido na gestão da empresa, o devedor é quem implementará as medidas de reorganização para superar a crise econômico-financeira.

\footnotetext{
${ }^{103}$ Art. L.631-12: "Outre les pouvoirs qui leur sont conférés par le présent titre, la mission du ou des administrateurs est fixée par le tribunal. Ce dernier les charge ensemble ou séparément d'assister le débiteur pour tous les actes relatifs à la gestion ou certains d'entre eux, ou d'assurer seuls, entièrement ou en partie, l'administration de l'entreprise. Lorsque le ou les administrateurs sont chargés d'assurer seuls et entièrement l'administration de l'entreprise et que chacun des seuils mentionnés au quatrième alinéa de l'article L. 621-4 est atteint, le tribunal désigne un ou plusieurs experts aux fins de les assister dans leur mission de gestion. Dans les autres cas, il a la faculté de les désigner. Le président du tribunal arrête la rémunération de ces experts, mise à la charge de la procédure. Dans sa mission, l'administrateur est tenu au respect des obligations légales et conventionnelles incombant au débiteur. A tout moment, le tribunal peut modifier la mission de l'administrateur sur la demande de celui-ci, du mandataire judiciaire, du ministère public ou d'office. L'administrateur fait fonctionner, sous sa signature, les comptes bancaires ou postaux dont le débiteur est titulaire quand ce dernier a fait l'objet des interdictions prévues aux articles L. 131-72 ou L. 163-6 du code monétaire et financier."
}

Tradução livre: Além das faculdades que lhes foram atribuídas neste título, as funções dos administradores judiciais serão determinadas pelo tribunal. Este último os encarregará de, juntos ou separadamente, ajudar o devedor em todos os atos de gestão, ou os encarregará de sozinhos, integral ou parcialmente, administrar a empresa. Quando os administradores tenham por função a gestão integral da empresa e se atinjam os objetivos mencionados no parágrafo quarto do artigo L.621-4, o Tribunal nomeará um ou vários peritos para que os ajudem em suas funções de gestão. Nos demais casos, os administradores terão a faculdade de nomear eles mesmos. O presidente do Tribunal determinará o valor da remuneração dos peritos nomeados do processo. Em sua função, o administrador judicial estará obrigado a respeitar as obrigações legais e convencionais refrentes ao devedor. O tribunal poderá, a qualquer momento, alterar as funções do administrador judicial, atendendo a pedido deste, do mandatário judicial, do Ministério Público e até mesmo de ofício. O administrador gerirá, com sua firma, as contas bancárias e postais de que o devedor era titular se a este tiverem sido impostas as inabilitações previstas nos artigos L.131-72 o L.163-6 do Código Monetário e Financeiro. 
O procédure de liquidation ${ }^{104}$, por fim, instaura-se sempre que o devedor for insolvente e o saneamento da empresa mostrar-se impossível, de modo que a liquidação judicial destina-se a encerrar as atividades da empresa, ou a executar o patrimônio do devedor mediante a cessão total ou parcial de seus bens (art. L.640-1) ${ }^{105}$. Embora, em princípio, as atividades do devedor sejam encerradas, a liquidação pode propiciar a preservação do negócio mediante a cessão da totalidade da empresa, motivo pelo qual PUGLIESI (2013, p. 69) aponta que, segundo entendimento majoritário dos doutrinadores, essa modalidade de realização do ativo é, na realidade, uma técnica de recuperação da empresa em dificuldade, mas é necessário

ter em conta que a cessão da empresa realizada sob o âmbito de um procedimento de redressement coloca foco na manutenção da atividade com a continuação pelo próprio devedor; ao passo que, na liquidation, esta ocorre principalmente par atender aos interesses dos credores, mediante obtenção do melhor preço de venda.

Isso não obstante, a decretação da liquidação importa na manutenção dos administradores do devedor (se pessoa jurídica) em seus cargos, mas o poder de gestão é atribuído, com exclusividade, ao liquidante nomeado pelo tribunal (art. L. 641-9) ${ }^{106}$.

$104 \mathrm{O}$ procedimento de liquidação simplificada aplica-se sempre que o devedor não tenha bens imóveis, e quando o número de seus empregados nos seis meses anteriores à abertura do processo e o valor de seus negócios, antes dos impostos, forem inferiores aos limites fixados pelo Conselho de Estado (art. L. 641-2).

${ }^{105}$ Art. L.640-1: "Il est institué une procédure de liquidation judiciaire ouverte à tout débiteur mentionné à l'article L. 640-2 en cessation des paiements et dont le redressement est manifestement impossible. La procédure de liquidation judiciaire est destinée à mettre fin à l'activité de l'entreprise ou à réaliser le patrimoine du débiteur par une cession globale ou séparée de ses droits et de ses biens."

Tradução livre: É instituído procedimento de liquidação judicial a todo devedor indicado no artigo L.640-2 em estado de insolvência, quando no saneamento da empresa for manifestamente impossível. O procedimento de liquidação judicial destina-se a por fim à atividade da empresa ou a executar o patrimônio do devedor mediante a cessão em bloco ou em separado de seus direitos e bens.

106 Art. 641-9: “I. - Le jugement qui ouvre ou prononce la liquidation judiciaire emporte de plein droit, à partir de sa date, dessaisissement pour le débiteur de l'administration et de la disposition de ses biens même de ceux qu'il a acquis à quelque titre que ce soit tant que la liquidation judiciaire n'est pas clôturée. Les droits et actions du débiteur concernant son patrimoine sont exercés pendant toute la durée de la liquidation judiciaire par le liquidateur. Toutefois, le débiteur peut se constituer partie civile dans le but d'établir la culpabilité de l'auteur d'un crime ou d'un délit dont il serait victime. Le débiteur accomplit également les actes et exerce les droits et actions qui ne sont pas compris dans la mission du liquidateur ou de l'administrateur lorsqu'il en a été désigné. II. - Lorsque le débiteur est une personne morale, les dirigeants sociaux en fonction lors du prononcé du jugement de liquidation judiciaire le demeurent, sauf disposition contraire des statuts ou décision de l'assemblée générale. En cas de nécessité, un mandataire peut être désigné en leur lieu et place par ordonnance du président du tribunal sur requête de tout intéressé, du liquidateur ou du ministère public. Le siège social est réputé fixé au domicile du représentant légal de l'entreprise ou du mandataire désigné."

Tradução livre: I - A decisão que abre ou declara a liquidação judicial valerá de pleno direito para o devedor a partir de sua data, e importará na privação da administração e de disposição de seus bens, inclusive aqueles 


\section{Itália}

O direito concursal é regulado na Itália pela Legge fallimentare (Regio Decreto 16 marzo 1942, n. 267), que sofreu inúmeras alterações nos últimos anos, destacando-se as implementadas pela Lei no 392, de 24 de julho de 1978 (conhecida como Lei Prodi, que acentuou a necessidade de preservação da empresa), pelo Decreto Legislativo $n^{\circ} 35$, de 14 de março de 2005 (que modificou a disciplina da ação revocatória e da concordata preventiva) e pelo Decreto Legislativo $\mathrm{n}^{\circ}$ 05, de 9 de janeiro de 2006, que revogou as normas que previam a amministrazione controllata (FRANCO e SZTAJN, 2008, p. 217).

A legislação atualmente em vigor prevê os seguintes institutos concursais: (a) falência, regulada nos arts. 5 a 117 e 146 a 152 da Legge fallimentare, (b) a concordata falimentar, disciplinada nos arts. 124 a 141 do Regio Decreto 267, (c) a concordata preventiva, prevista nos arts. 160 a 166 da lei falimentar, (d) os acordos de reestruturação de dívidas, instituído pelo art. 182 bis da Legge fallimentare, e (e) o procedimento não judicial de administração extraordinária das grandes empresas em crise, disciplinado pelo Decreto Legislativo no 270, de 8 de julho de 1999 (PUGLIESE, 2013, p. 74).

A falência (fallimento), assim como dispõe a lei brasileira, tem como efeito privar o devedor da administração e do poder de disposição de seus bens, os quais poderes são atribuídos ao curador nomeado pelo juiz (arts. 31 e 42), que arrecada os bens do falido (art. 84) e realiza o ativo (art. 107) para pagar o passivo. Na hipótese, porém, de a arrecadação dos bens poder causar maior prejuízo aos credores do que a continuação provisória da empresa, pode o juiz autorizar o curador a prosseguir provisoriamente com a

que tiver adquirido de qualquer modo até que o procedimento de liquidação judicial seja concluído, O liquidante exercerá os direitos e as ações referentes ao patrimônio do devedor enquanto dure a liquidação judicial. Não obstante, o devedor poderá ser parte com o fim de determinar a culpabilidade do autor de um crime ou delito de que tenha sido vítima. O devedor exercerá os atos de disposição e de administração de seus bens, assim como os direitos que não sejam de responsabilidade do administrador quando este tiver sido nomeado. II - Se o devedor é uma pessoa jurídica, os dirigentes sociais que estiverem na função no momento da decisão da abertura do procedimento de liquidação judicial conservarão seus cargos, salvo disposição estatutária ou decisão da assembleia geral em contrário. Em caso de necessidade, e a pedido de qualquer pessoa interessada, do liquidante ou do Ministério Público, poderá ser nomeado em seu lugar, por decisão judicial. Neste caso se considerará que a sede social da empresa será o domicílio de seu representante legal ou o do mandatário designado. 
atividade, caso em que ao comitê de credores devem ser prestadas contas, no máximo trimestralmente, sobre a gestão provisória (art. 104).

A concordata falimentar, por sua vez, está disciplinada nos arts. 124 a 141 do Regio Decreto 16 marzo 1942, n. 267, e consiste, fundamentalmente, em uma forma alternativa de satisfação dos interesses dos credores de modo melhor (na realidade, menos ruim) que o previsto na falência ${ }^{107}$, destacando PUGLIESI $(2013$, p. 80) que nela o terceiro propõe a assunção das obrigações do falido (em percentual convencionado no plano quanto aos quirografários) e, em seguida, ocorre a transferência da propriedade (total ou parcial) dos bens arrecadados.

Daí que tanto o procedimento da falência quanto o da concordata falimentar são meios de liquidação do passivo. Situação diversa ocorre na concordata preventiva, cuja disciplina legal está nos arts. 160 a 166 da Legge fallimentare, e sua finalidade é permitir ao devedor a superação de sua crise econômico-financeira.

De fato, na concordata preventiva o devedor em crise pode apresentar aos credores plano contemplando a reestruturação de seus débitos e sua satisfação por qualquer

107 Art. 124. "La proposta di concordato può essere presentata da uno o più creditori o da un terzo, anche prima del decreto che rende esecutivo lo stato passivo, purché sia stata tenuta la contabilità ed $i$ dati risultanti da essa e le altre notizie disponibili consentano al curatore di predisporre un elenco provvisorio dei creditori del fallito da sottoporre all'approvazione del giudice delegato. Essa non può essere presentata dal fallito, da società cui egli partecipi o da società sottoposte a comune controllo se non dopo il decorso di un anno dalla dichiarazione di fallimento e purché non siano decorsi due anni dal decreto che rende esecutivo lo stato passivo. La proposta può prevedere: a) la suddivisione dei creditori in classi, secondo posizione giuridica ed interessi economici omogene $i$; $b$ ) trattamenti differenziati fra creditori appartenenti a classi diverse, indicando le ragioni dei trattamenti differenziati dei medesimi; c) la ristrutturazione dei debiti e la soddisfazione dei crediti attraverso qualsiasi forma, anche mediante cessione dei beni, accollo o altre operazioni straordinarie, ivi compresa l'attribuzione ai creditori, nonché a società da questi partecipate, di azioni, quote ovvero obbligazioni, anche convertibili in azioni o altri strumenti finanziari e titoli di debito.”

Tradução livre: A proposta de concordata pode ser apresentada por um ou mais credores ou por terceiros, mesmo antes da decisão que autoriza a liquidação do passivo, desde tenha sido mantida a contabilidade e os dados que dela resultam, e as outras informações disponíveis permitam ao curador organizar uma relação provisória dos credores do falido a ser submetida à aprovação do juiz encarregado. A proposta de concordata não pode ser apresentada pelo falido, de sociedade da qual ele participe ou sociedades sob controle comum, exceto após o decurso do prazo de um ano da declaração da falência, desde que não tenha transcorrido dois anos do decreto que torna executivo o estado passivo. A proposta pode prever: a) a divisão dos credores em classes, de acordo com a posição jurídica e interesses econômicos homogêneos; b) tratamento diferenciado para os credores pertencentes a diferentes classes, indicando as razões para a diferença de tratamento entre eles; c) a reestruturação das dívidas e a satisfação dos credores por qualquer forma, inclusive por meio da venda de ativos, adjudicação ou outras operações extraordinárias, incluindo a atribuição aos credores ou a sociedades das quais participem, de ações, quotas ou títulos, até mesmo conversíveis em ações ou outros instrumentos financeiros e títulos de dívida. 
forma, inclusive a transferência de bens e da empresa a terceiros que assumam o passivo $^{108}$. Especificamente em relação à administração do devedor, o art. 167 da Lei Falimentar dispõe que "durante la procedura di concordato, il debitore conserva l'amministrazione dei suoi beni e l'esercizio dell'impresa, sotto la vigilanza del commissario giudiziale." Isso não obstante, os empréstimos, as transações, os compromissos, a alienação de bens imóveis, a concessão de hipotecas ou penhores, fianças, renúncias de mandato, o reconhecimento dos direitos de terceiros, cancelamentos de hipotecas, e demais atos que vão além da administração ordinária são ineficazes em relação aos credores se praticados sem a permissão por escrito do juiz ${ }^{109}$.

${ }^{108}$ Art. 160. "L'imprenditore che si trova in stato di crisi può proporre ai creditori un concordato preventivo sulla base di un piano che può prevedere: a) la ristrutturazione dei debiti e la soddisfazione dei crediti attraverso qualsiasi forma, anche mediante cessione dei beni, accollo, o altre operazioni straordinarie, ivi compresa l'attribuzione ai creditori, nonché a società da questi partecipate, di azioni, quote, ovvero obbligazioni, anche convertibili in azioni, o altri strumenti finanziari e titoli di debito; b) l'attribuzione delle attività delle imprese interessate dalla proposta di concordato ad un assuntore; possono costituirsi come assuntori anche $i$ creditori o società da questi partecipate o da costituire nel corso della procedura, le azioni delle quali siano destinate ad essere attribuite ai creditori per effetto del concordato; c) la suddivisione dei creditori in classi secondo posizione giuridica e interessi economici omogenei; $d$ ) trattamenti differenziati tra creditori appartenenti a classi diverse. La proposta può prevedere che i creditori muniti di privilegio, pegno o ipoteca, non vengano soddisfatti integralmente, purché il piano ne preveda la soddisfazione in misura non inferiore a quella realizzabile, in ragione della collocazione preferenziale, sul ricavato in caso di liquidazione, avuto riguardo al valore di mercato attribuibile ai beni o diritti sui quali sussiste la causa di prelazione indicato nella relazione giurata di un professionista in possesso dei requisiti di cui all'art. 67, terzo comma, lettera d). Il trattamento stabilito per ciascuna classe non può avere l'effetto di alterare l'ordine delle cause legittime di prelazione. Ai fini di cui al primo comma per stato di crisi si intende anche lo stato di insolvenza."

Tradução livre: Art. 160. O empresário que se encontra em estado de crise pode propor aos credores uma concordata preventiva com base em um plano que pode prever: a) a reestruturação das dívidas e o pagamento dos créditos através de qualquer forma, mesmo mediante cessão dos bens, adjudicação, ou outras operações extraordinárias, incluindo a atribuição aos credores, bem como a sociedades por eles detidas, de ações, cotas ou obrigações, mesmo convertíveis em ações, ou outros instrumentos financeiros e títulos de débito; b) a atribuição das atividades das empresas envolvidas na proposta de concordata a um cessionário; podem se constituir como cessionários também os credores ou sociedades por eles detidas, ou que devem ser constituídas durante o procedimento, as ações das quais são destinadas para serem atribuídas aos credores para efeito da concordata; c) a subdivisão dos credores em classes de acordo com a posição jurídica e interesses econômicos homogêneos; d) tratamentos diferenciados entre credores pertencentes a classes diferentes. A proposta pode prever que os credores com privilégio, penhor ou hipoteca, não serão pagos integralmente, desde que o plano preveja seu pagamento em medida não inferior àquela realizável, em razão da colocação preferencial, sobre o rendimento em caso de liquidação, considerando o valor de mercado atribuível aos bens ou direitos sobre os quais subsiste a causa de preempção indicado no relatório juramentado de um profissional que possua os requisitos que constam no art. 67, terceiro parágrafo, letra d). O tratamento estabelecido para cada classe não pode ter o efeito de alterar a ordem das causas legítimas de preempção. Para fins do que consta no primeiro parágrafo, por estado de crise entende-se também o estado de insolvência.

109 Art. 167. "Durante la procedura di concordato, il debitore conserva l'amministrazione dei suoi beni e l'esercizio dell'impresa, sotto la vigilanza del commissario giudiziale. I mutui, anche sotto forma cambiaria, le transazioni, i compromessi, le alienazioni di beni immobili, le concessioni di ipoteche o di pegno, le fideiussioni, le rinunzie alle liti, le ricognizioni di diritti di terzi, le cancellazioni di ipoteche, le restituzioni di pegni, le accettazioni di eredità e di donazioni e in genere gli atti eccedenti la ordinaria amministrazione, compiuti senza l'autorizzazione scritta del giudice delegato, sono inefficaci rispetto ai creditori anteriori al concordato. Con il decreto previsto dall'articolo 163 o con successivo decreto, il tribunale può stabilire un limite di valore al di sotto del quale non è dovuta l'autorizzazione di cui al secondo comma." 
Caso, contudo, o comissário judicial apure que o devedor ocultou seus bens, dolosamente omitiu débitos, ou cometeu atos fraudulentos, deve ele denunciar o fato ao juiz, que pode convolar a concordata em falência (art. 173) ${ }^{110}$. Em suma, como destaca STANGHELLINI (2007, p. 354) $)^{111}$,

è evidente che la procedura di concordato preventivo constituice un'ultima, e ottima occasione per il debitore di continuare a gestire il suo patrimônio anche in una situazione in cui, verosilmilmente, $i$ creditore dovrebbero assumerme il controlo, visto che esso è com tutta probabilità insufficiente a soddisfarti tutti. Non solo: il controllo sul suo patrimônio e il potere di formular ela proposta como ritiene più opportuno consentono

Tradução livre: Art. 167. Durante o procedimento de concordata, o devedor conserva a administração de seus bens e o exercício da empresa, sob a vigilância do gestor judicial. Os empréstimos, mesmo sob forma cambial, as transações, os compromissos, as alienações de bens imóveis, as concessões de hipotecas ou de penhor, as fianças, as renúncias às ações judiciais, as verificações de direitos de terceiros, os cancelamentos de hipotecas, as restituições de penhores, as aceitações de herança e de doações e, em geral, os atos restantes da administração ordinária, realizados sem a autorização por escrito do juiz delegado, são ineficazes em relação aos credores anteriores à concordata. Com o decreto previsto pelo artigo 163 ou com sucessivo decreto, o tribunal pode estabelecer um limite de valor abaixo do qual não é devida a autorização que consta no segundo parágrafo.

${ }^{110}$ Art. 173. "Il commissario giudiziale, se accerta che il debitore ha occultato o dissimulato parte dell'attivo, dolosamente omesso di denunciare uno o più crediti, esposto passività insussistenti o commesso altri atti di frode, deve riferirne immediatamente al tribunale, il quale apre d'ufficio il procedimento per la revoca dell'ammissione al concordato, dandone comunicazione al pubblico ministero e ai creditori. La comunicazione ai creditori è eseguita dal commissario giudiziale a mezzo posta elettronica certificata ai sensi dell'articolo 171, secondo comma. All'esito del procedimento, che si svolge nelle forme di cui all'articolo 15, il tribunale provvede con decreto e, su istanza del creditore o su richiesta del pubblico ministero, accertati $i$ presupposti di cui agli articoli 1 e 5, dichiara il fallimento del debitore con contestuale sentenza, reclamabile a norma dell'articolo 18. Le disposizioni di cui al secondo comma si applicano anche se il debitore durante la procedura di concordato compie atti non autorizzati a norma dell'articolo 167 o comunque diretti a frodare le ragioni dei creditori, o se in qualunque momento risulta che mancano le condizioni prescritte per l'ammissibilità del concordato."

Tradução livre: Art. 173. O gestor judicial, se for verificado que o devedor ocultou ou dissimulou parte do ativo, omitiu dolosamente denunciar um ou mais créditos, expôs passivos inexistentes ou cometeu outros atos de fraude, deve informar sobre isto imediatamente ao tribunal, o qual em caráter de ofício inicia o procedimento para a revogação da admissão à concordata, fazendo sua comunicação ao ministério público e aos credores. A comunicação aos credores é realizada pelo gestor judicial por meio do correio eletrônico certificado nos termos do artigo 171, segundo parágrafo. Na conclusão do procedimento, que é realizado nas formas que constam no artigo 15, o tribunal efetua com decreto e, a pedido do credor, ou a pedido do ministério público, após verificação dos pressupostos que constam nos artigos 1 e 5, declara a falência do devedor com sentença simultânea reclamável de acordo com o artigo 18. As disposições que constam no segundo parágrafo aplicam-se ainda que o devedor, durante o procedimento de concordata, cumpra atos não autorizados de acordo com o artigo 167 ou, de qualquer maneira, destinados a fraudar as razões dos credores, ou se em qualquer momento constar que faltam as condições estabelecidas para a admissibilidade da concordata.

111 Tradução de PUGLIESI (2013, p. 78): É evidente que o procedimento de concordato preventivo constitui uma última, e ótima, oportunidade para o devedor de continuar a gerir seu patrimônio, mesmo em uma situação na qual, verdadeiramente, os credores deveriam assumir o controle deste, visto que este é com toda certeza insuficiente para satisfazer a todos eles. Não apenas: o controle sobre o seu patrimônio e o poder de formular proposta como melhor julgar oportuno, autoriza os devedores a encaminharem uma solução (não apenas no interesse dos credores, mas) também do próprio devedor. 
al debitori de indirrizare la soluzione (non solo nell'interesse dei creditori, ma) anche nel proprio interesse.

Além da concordata preventiva, a Lei Falimentar da Itália também contempla, no art 182 bis, os acordos de reestruturação de dívidas como meio para o devedor superar sua crise. Esse acordo de reestruturação de dívida é denominado por PERIN (2009, p. 89) como "acordo pré-concursal (espécie de recuperação extrajudicial informal)", porquanto o devedor em crise econômica pode depositar plano aprovado por pelo menos $60 \%$ de seus credores, acompanhado de laudo contábil que ateste a veracidade dos lançamentos contábeis e a viabilidade do acordo, cuja eficácia independe de homologação ou provimento judicial.

Por último, a legislação italiana contempla a administração extraordinária das grandes empresas insolventes, cuja principal característica é que os procedimentos são administrativos e extrajudiciais, e conta com a ativa participação da autoridade pública, pois para superar a crise de grandes empresas geralmente é indispensável a obtenção de financiamento.

Bem por isso, PERIN (2009, p. 89) esclarece que esse procedimento de administração extraordinária tem por finalidade recuperar as empresas importantes para a economia do país, que já receberam créditos especiais do governo, mas que venham a enfrentar crises econômicas, na qual hipótese o Ministério da Indústria nomeará um ‘supercomissário', como substituto dos órgãos sociais a quem será atribuído o encargo de "reestruturar a empresa e apresentar um plano de reorganização a ser submetido à autoridade administrativa encarregada do procedimento."

\section{Estados Unidos}

O processo falimentar é regulado nos Estados Unidos pelo Bankruptcy Code, de 1978, que sucedeu ao Bankrupcy Act de 1898, o qual havia sofrido inúmeras alterações e reformas pontuais, entre as quais destaca-se o Chandler Act, de 1938, editado no bojo do New Deal, que inseriu a intervenção governamental e reduziu a autonomia de credores e devedor, destacando CEREZETTI (2012, p. 100), no que interessa para o objeto desta dissertação, que essas inovações referem-se 
principalmente aos dispositivos do Chapter $X$, capítulo então destinado a tratar da reorganização de grandes empresas. Os casos por ele regulados e que incidissem em um valor mínimo de dívidas deveriam contar obrigatoriamente com um trustee, que, no lugar dos administradores do devedor, passava a conduzir os negócios da companhia e o próprio processo judicial [...] como se poderia imaginar, a mandatória nomeação de um trustee para conduzir as atividades da empresa ocasionou a queda do número de pedidos de reorganização. Administradores, que temiam seu próprio afastamento evitavam ao máximo a solução judicial à crise empresarial. Ao lado disso, grandes empresas passaram a se desviar do Chapter $X$ e a recorrer a outro capítulo introduzido pelo Chandler Act. Tendo em vista que o Chapter XI, inicialmente designado para cuidar de empresas de pequeno porte, não incluía exigências como a designação de um trustee ou a participação do órgão supervisor do mercado de valores mobiliários mas, da mesma forma, permitia a reorganização empresarial, ele tornou-se o conjunto de regras mais utilizado.

De fato, segundo retrata SKEEL (2004, p. 126) ${ }^{112}$, a partir de 1939, quando foram apresentados 577 pedidos de reorganização, houve sensível redução na quantidade de processos, fundamentalmente em virtude da norma impositiva de afastamento dos administradores do devedor e nomeação compulsória de trustee:

\begin{tabular}{|c|c|c|c|c|c|}
\hline Ano & $\mathrm{N}^{\circ}$ de pedidos & Ano & $\mathrm{N}^{\mathbf{o}}$ de pedidos & Ano & $\mathrm{N}^{\mathbf{o}}$ de pedidos \\
\hline & & & & & \\
\hline 1939 & 577 & 1950 & 102 & 1961 & 119 \\
\hline 1940 & 291 & 1951 & 75 & 1962 & 104 \\
\hline 1941 & 291 & 1952 & 64 & 1963 & 133 \\
\hline 1942 & 165 & 1953 & 61 & 1964 & 103 \\
\hline 1942 & 109 & 1954 & 90 & 1965 & 88 \\
\hline 1944 & 95 & 1955 & 80 & 1966 & 93 \\
\hline 1945 & 70 & 1956 & 61 & 1967 & 138 \\
\hline 1946 & 60 & 1957 & 71 & 1968 & 128 \\
\hline 1947 & 94 & 1958 & 75 & 1969 & 87 \\
\hline 1948 & 105 & 1959 & 99 & 1970 & 115 \\
\hline 1949 & 113 & 1960 & 112 & & \\
\hline
\end{tabular}

Em outras palavras, para evitar serem afastados da gestão da empresa, os administradores procrastinavam ao máximo a apresentação de pedidos de reorganização e quando faziam, buscavam fundá-lo no Chapter XI da legislação então em vigor (o qual destinava-se às empresas de pequeno porte), onde não se estipulava a nomeação

112 Informações obtidas pelo autor a partir de Hearings on S. 235 and S.236 before the Subcommitte on Improvements in Judicial Machinery of the Senate Committee on the Judiciary, $94^{\text {th }}$ Congr. $1^{\text {st }}$ sess, 778 (1975). 
compulsória de trustee para substituir os administradores do devedor (SKEEL, 2004, p. $161)^{113}$.

Exatamente porque muitos devedores que deveriam se submeter às regras do Chapter $X$ acabavam por optar pelo procedimento estabelecido no Chapter XI, EPSTEIN, NICKLES e WHITE (1993, p. 732) acrescentam que muito tempo e dinheiro foram gastos apenas para decidir-se a que regras de reorganização deveria se submeter determinado devedor, citando inclusive, em nota de rodapé, que "one court deciding a dispute over which chapter was appropriate commented that the patient would probably die while the doctors argued which operating table he should be on. Securities \& Ex-changed Commission v. Canandaigua Enterprises Corp., 339 F.2d 14,19 (2d Cir. 1964)” 114.

Esta legislação acabou sendo profundamente alterada pelo Bankruptcy Code $e^{115}$ de 1978, o qual é composto atualmente dos seguintes capítulos: Chapter 1: General Provisions, definitions and Rules of Construction; Chapter 3: Case Administration; Chapter 5: creditors, the debtor and the Estate; Chapter 7: Liquidation; Chapter 9: Adjustment of the Debts of a Municipality; Chapter 11: Reorganization; Chapter 12: Adjustments of the Debts of a Family Farm or Fishermen With Regular Income; Chapter 13: Adjustment of the Debts of an Individual With Regular Income; Chapter 15: Ancillary and Other Cross-Border Cases ${ }^{116}$.

Contempla o Bankruptcy Code, fundamentalmente, dois procedimentos aplicáveis às sociedades empresariais ${ }^{117}$, a saber: a liquidation, que equivale à falência prevista na legislação brasileira e está regulada no Chapter 7 , e o reorganization (objeto do

\footnotetext{
${ }^{113}$ No mesmo sentido, BOLTON, 2003, p. 6

114 Tradução livre: uma corte julgando disputa sobre qual capítulo era o apropriado comentou que o paciente provavelmente morreria enquanto os médidos discutiam que mesa cirúrgica deveria ser utilizada.

115 A redação do Bankrupcy Code referida nesta dissertação foi extraída de consulta realizada em 22.09.2013, na seguinte página da internet: http://uscode.house.gov/browse/prelim@title11\&edition=prelim

116 Tradução livre: Capítulo $1^{\text {o}}$ : Regras Gerais, definições e regras de construção; Capítulo $3^{\circ}$ : administração da causa; Capítulo 5: credores, o devedor e o Estado; Capítulo 7: Liquidação; Capítulo 9: acordos de débito de um Município; Capítulo 11: Reorganização; Capítulo 12: acordos de débito de uma fazenda familiar com renda anual regular; Capítulo 13: acordos de débito de uma pessoa natural com renda regular; Capítulo 15: auxiliares e outros casos transfronteiriços.

117 Tanto o liquidation quanto o reorganization aplicam-se a pessoas físicas e jurídicas, empresariais ou não. Entretanto, tendo em vista os procedimentos estabelecidos no Chapter 11, que envolvem altos custos, apenas as sociedades empresariais é que se valem desse processo de reabilitação.
} 
Chapter 11), colocado à disposição do devedor como meio para superar suas dificuldades econômico-financeiras, de modo a permitir a continuação do negócio, pois como destacam EPSTEIN, NICKLES e WHITE (1993, p. 8), no reorganization, que contempla a reabilitação do devedor, os credores não buscam dividir entre si os bens do devedor, mas visam os lucros que terão nos futuros negócios que com ele contratarão ${ }^{118}$.

O pedido de reorganização pode ser apresentado tanto pelo devedor (voluntary petition, art. 301) quanto por credores (involuntary petition), hipótese na qual, nos termos do art. 303, "b", do código falimentar, há dois requisitos a ser preenchidos: deve haver no mínimo três credores, e a soma de seus créditos deve ser de, no mínimo, Us \$10 mil (dez mil dólares norte-americanos) ${ }^{119}$.

A apresentação do requerimento, quer voluntário, quer involuntário, tem como efeito imediato o automatic stay ${ }^{120}$, que consiste na suspensão, desde a data do pedido, de

\footnotetext{
${ }^{118}$ No mesmo sentido: PERIN (2009, p. 58).

${ }^{119}$ Art. 303, " $b$ ": An involuntary case against a person is commenced by the filing with the bankruptcy court of a petition under chapter 7 or 11 of this title: (1) by three or more entities, each of which is either a holder of a claim against such person that is not contingent as to liability or the subject of a bona fide dispute as to liability or amount, or an indenture trustee representing such a holder, if such noncontingent, undisputed claims aggregate at least $\$ 10,000$ more than the value of any lien on property of the debtor securing such claims held by the holders of such claims; (2) if there are fewer than 12 such holders, excluding any employee or insider of such person and any transferee of a transfer that is voidable under section 544, 545, $547,548,549$, or 724(a) of this title, by one or more of such holders that hold in the aggregate at least $\$ 10,000$ of such claims; (3) if such person is a partnership: (A) by fewer than all of the general partners in such partnership; or $(B)$ if relief has been ordered under this title with respect to all of the general partners in such partnership, by a general partner in such partnership, the trustee of such a general partner, or a holder of a claim against such partnership; or (4) by a foreign representative of the estate in a foreign proceeding concerning such person."
}

Tradução livre: Art. 303, "b": Um caso involuntário contra uma pessoa ser iniciado pela apresentação, junto ao tribunal de falência, de um pedido segundo o capítulo 7 ou 11 deste título: (1) por três ou mais empresas, sendo cada uma delas a titular de uma reivindicação contra tal pessoa que não esteja condicionada à responsabilidade ou não seja o objeto de uma disputa de boa-fé quanto à responsabilidade ou o valor, ou um administrador fiduciário representante de tal titular, se tais reivindicações não condicionadas e não disputadas totalizarem, no mínimo, $\$ 10.000$ mais que o valor de qualquer ônus sobre o bem do devedor que garante as reivindicações detidas pelos titulares das referidas reivindicações; (2) caso haja menos do que 12 titulares, excluindo qualquer empregado ou insider [detentor de informações privilegiadas] de tal pessoa e qualquer beneficiário de uma transferência que seja anulável segundo a seção 544, 545, 547, 548, 549, ou 724(a) deste título, por um ou mais dos referidos titulares que detenham, no total, no mínimo $\$ 10.000$ de tais reivindicaç̃̃es; (3) caso tal pessoa seja uma sociedade: (A) por menos que todos os sócios comanditados; ou (B) caso um recurso tenha sido ordenado segundo este título em relação a todos os sócios comanditados em tal sociedade, por um sócio comanditado na referida sociedade, pelo fiduciário do sócio comanditado ou por um titular de uma reivindicação contra a referida sociedade; ou (4) por um representante estrangeiro dos bens em um processo estrangeiro referente a tal pessoa.

${ }^{120}$ Segundo consta expressamente do Relatório do Senado n ${ }^{\circ}$ 95-989 (consultado em 22.09.2013 na página da internet http://uscode.house.gov/browse/prelim@title11\&edition=prelim), "The automatic stay is one of the fundamental debtor protections provided by the bankruptcy laws. It gives the debtor a breathing spell from 
todas as ações e execuções de credores individuais, ou que tenham por objeto bens de propriedade do devedor (art. 362, “a”). Apenas os atos expressamente excetuados na alínea "b" do mesmo art. 362 é que não se suspendem, tais como, exemplificativamente, as ações penais, as que tiverem por objeto reconhecimento de paternidade, guarda de filhos, alimentos, retenção de imposto, entre outras.

No curso do procedimento de reorganização deverá ser apresentado plano de recuperação que será submetido à aprovação dos credores e do juiz, plano esse que pode ser apresentado tanto pelo devedor (a quem se atribui a prerrogativa de, com exclusividade, apresentá-lo nos primeiros cento e vinte dias contados do pedido de reorganização) quanto por terceiros interessados ${ }^{121}$, de modo que mais de um plano poderá vir a ser apresentado, mas somente um poderá vir a ser confirmado.

A confirmação do plano de reorganização ocorre com (a) a aprovação dos credores e judicial (art. 1.129, "a" do Bankruptcy Code), ou (b) apenas judicial (craw down), desde que preenchidos os requisitos estabelecidos no art. 1.129, "b", os quais exigem que o plano, apesar de não ter sido aprovado por todas as classes de credores por ele afetadas, atenda todas as demais exigências legais, ou seja, "if the plan does not

his creditors. It stops all collection efforts, all harassment, and all foreclosure actions. It permits the debtor to attempt a repayment or reorganization plan, or simply to be relieved of the financial pressures that drove him into bankruptcy."

Tradução livre: A suspensão automática é uma das proteções fundamentais ao devedor previstas pelas leis de falência. Ela concede ao devedor um alívio na pressão dos credores. Ela interrompe todos os esforços de cobrança, assédio, e todas as ações de encerramento. Ela permite ao devedor elaborar um plano de reorganização ou repactuação, ou simplesmente o alivia das pressões financeiras que o levaram à insolvência.

${ }^{121}$ Art. 1.121: "(a) The debtor may file a plan with a petition commencing a voluntary case, or at any time in a voluntary case or an involuntary case. (b) Except as otherwise provided in this section, only the debtor may file a plan until after 120 days after the date of the order for relief under this chapter. (c) Any party in interest, including the debtor, the trustee, a creditors' committee, an equity security holders' committee, a creditor, an equity security holder, or any indenture trustee, may file a plan if and only if: (1) a trustee has been appointed under this chapter; (2) the debtor has not filed a plan before 120 days after the date of the order for relief under this chapter; or (3) the debtor has not filed a plan that has been accepted, before 180 days after the date of the order for relief under this chapter, by each class of claims or interests that is impaired under the plan."

Tradução livre: (a) O devedor pode apresentar o plano com a petição inicial no caso de requerimento voluntário, ou a qualquer momento no caso de pedido voluntário ou involuntário. (b) Exceto se houver disposição em contrário nesta seção, somente o devedor pode apresentar plano no prazo de até 120 dias após o pedido de reorganização. (c) Qualquer interessado, incluindo o devedor, o trustee, o comitê de credores, o comitê de acionistas, credor, acionista, ou qualquer agente fiduciário, poderá apresentar um plano se, e somente se: (1) tiver sido nomeado trustee na forma deste capítulo; (2) o devedor não tiver apresentado plano no prazo de 120 dias após o pedido reorganização, ou (3) o devedor não tiver apresentado plano aceito, antes de 180 dias da data do pedido de reorganização, por cada classe de credores afetados pelo plano. 
discriminate unfairly, and is fair and equitable, with respect to each class of claims or interests that is impaired under, and has not accepted, the plan" 122.

O pedido de reorganização não importa, em regra, o afastamento do devedor da administração de seus bens e da gestão da empresa, com sua consequente substituição pelo trustee $^{123}$. Ao contrário, porque conhece seu negócio e para que não retarde a apresentação do pedido de reorganização, o devedor (ou seus administradores se se tratar de pessoa jurídica) é mantido na gestão, na qualidade de debtor in possession (art. 1.101, “1”), ou seja, como responsável fiduciário pela totalidade dos bens e direitos, que formam o denominado property of the estate (art. 541).

O afastamento do devedor da gestão somente ocorre se houver fraude ou se for de interesse de credores ou acionistas, nos precisos termos do art. 1.104, "a", do Bankruptcy Code:

(a) At any time after the commencement of the case but before confirmation of a plan, on request of a party in interest or the United States trustee, and after notice and a hearing, the court shall order the appointment of a trustee:

(1) for cause, including fraud, dishonesty, incompetence, or gross mismanagement of the affairs of the debtor by current management, either before or after the commencement of the case, or similar cause, but not including the number of holders of securities of the debtor or the amount of assets or liabilities of the debtor; or

(2) if such appointment is in the interests of creditors, any equity security holders, and other interests of the estate, without regard to the number of holders of securities of the debtor or the amount of assets or liabilities of the debto. ${ }^{124}$.

\footnotetext{
122 Tradução livre: Art. 1.129, “b”: (...) se o plano não discrimina injustamente, e é justo e equitativo, em relação a cada classe de credores afetada pelo plano e que não o aceitou.

${ }^{123}$ Diferentemente do que ocorre no processo de liquidation, em que a nomeação do trustee é obrigatória, assumindo ele a posse dos bens do falido, que são vendidos para o pagamento dos credores.

124 Tradução livre: (a) A qualquer momento após o pedido de reorganização, mas antes da aprovação do plano, a pedido de uma parte interessada ou do "United States Trustee", e depois de uma audiência, o tribunal poderá ordenar a nomeação de um administrador: (1) por justa causa, incluindo as fraudes, improbidade, incompetência ou má gestão dos negócios do devedor pela atual administração, antes ou depois do início do processo, ou causas similares relevantes, independentemente do número de acionistas ou do valor do ativo e do passivo do devedor, ou (2) se a nomeação for do interesse dos credores, acionistas, ou outros interesses da massa, independentemente do número de acionistas ou do valor do ativo e do passivo do devedor.
} 
Daí que, como regra geral, o devedor é mantido na gestão da empresa em reorganização, e somente excepcional e justificadamente é que será ele afastado e substituído, na condução dos negócios, pelo trustee. Isso não obstante, mesmo no caso de ter sido nomeado trustee, o juiz poderá, a pedido de qualquer interessado e antes da confirmação do plano de recuperação, reconduzir o devedor à administração da empresa (art. 1.105).

Havendo pedido de afastamento do devedor e nomeação do trustee, se o juiz decidir que não é o caso de acolher o pedido, ele deve determinar a nomeação de um auditor (examiner) para investigar a conduta do devedor, de modo a apurar a eventual ocorrência de fraude, improbidade, má gestão ou negligência (art. 1.104, “c”).

Permanecendo o devedor na administração de seus bens e empresa, a ele são impostas todas as obrigações fiduciárias a que se submete o trustee, com exceção das obrigações de investigação ${ }^{125}{ }_{-}^{126}$, ficando ainda sujeito à fiscalização pelos credores.

Acrescente-se, por fim, que a manutenção do devedor na gestão da empresa, como debtor in possession, também tem reflexos nas relações entre os acionistas e os administradores, especialmente nos Estados Unidos, onde prevalece o controle difuso das companhias, pois como ressaltam EPSTEIN, NICKLES e WHITE (1993, p. 742),

\footnotetext{
${ }^{125}$ Art. 1.107: "(a) Subject to any limitations on a trustee serving in a case under this chapter, and to such limitations or conditions as the court prescribes, a debtor in possession shall have all the rights, other than the right to compensation under section 330 of this title, and powers, and shall perform all the functions and duties, except the duties specified in sections 1106(a)(2), (3), and (4) of this title, of a trustee serving in a case under this chapter."

Tradução livre: (a) Sem prejuízo de eventuais limitações a que se submete o trustee nomeado em um processo de reorganização, e subordinada às limitações ou condições fixadas pelo juiz, o devedor terá todos os direitos, exceto o direito a indenização da seção 330 deste título, e os poderes e desempenhará todas as funções e deveres, exceto os especificados nos arts. 1106 (a) (2), (3) e (4) do presente título, de um trustee nomeado na forma deste capítulo."

126 O Relatório do Senado n ${ }^{\circ}$ 95-989 (http://uscode.house.gov/browse/prelim@title11\&edition=prelim, consultado em 22.09.2013) destaca, em relação ao art. 1.107 do Bankruptcy Code, que "this section places a debtor in possession in the shoes of a trustee in every way. The debtor is given the rights and powers of a chapter 11 trustee. He is required to perform the functions and duties of a chapter 11 trustee (except the investigative duties). He is also subject to any limitations on a chapter 11 trustee, and to such other limitations and conditions as the court prescribes."

Tradução livre: esta seção atribui ao devedor a mesma posição do trustee em todos os sentidos. Ao devedor são atribuídos os direitos e poderes do trustee nomeado na forma deste capítulo 11. Do devedor são exigidas a execução das funções e os deveres do trustee nomeado na forma deste capítulo 11 (exceto as funções de investigação). O devedor também está sujeito a todas as limitações impostas ao trustee neste capítulo 11, e a quaisquer outras limitações e condições impostas pelo juiz.
} 
the owners' right to choose and control management is clear prior the bankruptcy; however, when the bankruptcy petition is filed, the owners' ability to control management becomes more difficult. The debtor in possession no longer stands in a fiduciary relationship with the owners, but rather, his fiduciary obligations run to 'the estate'. Thus, the debtor in possession has the responsibility to act in the best interest of the estate as a whole. This entails protecting and treating fairly the various groups with claims against the estate" 127

\footnotetext{
${ }^{127}$ Tradução livre: o direito dos acionistas de escolher e controlar os administradores é claro antes do processo falimentar. Entretanto, no momento em que é apresentado o pedido de reorganização, a possibilidade dos acionistas controlarem os administradores torna-se mais difícil. Estando na posse dos bens do devedor, a relação fiduciária dos administradores não será para com os acionistas, mas para com todos os interessados. Em consequência, os administradores têm a obrigação de agir no interesse de todo o grupo. Isto implica proteger e tratar de forma justa os vários grupos de interessados.
} 
CAPÍTULO III - A NOMEAÇÃO DO GESTOR JUDICIAL É EXCEÇÃO À REGRA GERAL DE MANUTENÇÃO DO DEVEDOR 


\section{CAPÍtULO III - A NOMEAÇÃO DO GESTOR JUDICIAL É EXCEÇÃO À REGRA GERAL DE MANUTENÇÃO DO DEVEDOR}

A Lei de Recuperação de Empresas e Falência (Lei no 11.101, de 9.2.2005), introduziu no direito positivo brasileiro uma profunda alteração nos procedimentos para a reorganização das empresas em dificuldades econômico-financeiras, com a substituição da concordata pela recuperação judicial e extrajudicial, porque o modelo jurídico da concordata, enquanto favor legal, esgotou-se (SIMIONATO, 2008, p. 27).

Na legislação revogada (Decreto-Lei n ${ }^{\circ}$ 7.661, de 21.6.1945), se o devedor em dificuldades preenchesse determinados requisitos legais, ainda que a empresa não fosse economicamente viável, o devedor tinha direito à concordata preventiva, por meio da qual a lei lhe concedia desconto e/ou prazo para o pagamento dos seus débitos quirografários.

A realidade, porém, é que, como destaca o Deputado BIOLCHI (2007, p. XXXVIII), Relator na Câmara dos Deputados do Projeto da Lei de Recuperação de Empresas e Falência, cerca de $90 \%$ das empresas que impetravam pedido de concordata preventiva tinham sua falência declarada, pois as regras da antiga legislação favoreciam mais a liquidação da sociedade do que a superação da crise econômico-financeira, pois (a) apenas os débitos quirografários estavam sujeitos à concordata preventiva (art. 147); e (b) o devedor poderia vir a ter sua falência decretada se convocasse seus credores e lhes propusesse um acordo, ainda que apenas um dos credores não aceitasse a proposta $\left(\operatorname{art} .2^{\circ}\right.$ ).

Exatamente porque a revogada Lei de Falências não favorecia o soerguimento das sociedades em crise, o Senador TEBET (2007, p. 383), no Relatório que apresentou à Comissão de Assuntos Econômicos do Senado Federal, referente ao Projeto de Lei da Câmara $\mathrm{n}^{\mathbf{0}} 71$, de 2003, destacou que

a proposição que originou o PLC ${ }^{\circ} 71$, de 2003, foi trazida pelo Executivo à apreciação do Congresso Nacional em razão da relativa obsolescência da Lei de Falências, motivada por profundas alterações ocorridas no panorama econômico desde sua entrada em vigor em 1945. Seria de surpreender que diploma tão longevo ainda fosse capaz de reger a complexa temática da insolvência e da falência. 
De acordo com o Relatório do Senador TEBET (2007, p. 394), no Projeto de Lei $\mathrm{n}^{\mathrm{o}} 71$ (e nas modificações sugeridas no próprio relatório) foram adotados os seguintes princípios: (a) "Preservação da empresa"128; (b) "Separação dos conceitos de empresa e empresário" 129; (c) "Recuperação das sociedades e empresários recuperáveis"130; (d) "Retirada do mercado de sociedades ou empresários não recuperáveis"; (e) "Proteção aos trabalhadores"; (f) "Redução do custo do crédito no Brasil"; (g) "Celeridade e eficiência dos processos judiciais"; (h) "Segurança jurídica"; (i) "Participação ativa dos credores"; (j) "Maximização do valor dos ativos do falido"; (k) "Desburocratização da recuperação de microempresas e empresas de pequeno porte"; e (1) "Rigor na punição de crimes relacionados à falência e à recuperação judicial."

Isto não obstante, o próprio Relator acrescentou que

naturalmente nem sempre é possível a perfeita satisfação de cada um desses enunciados, principalmente quando há conflito entre dois ou mais deles. Nesses casos, é necessário sopesar as possíveis consequências sociais e econômicas e buscar o ponto de conciliação, a configuração mais justa e que represente o máximo benefício possível à sociedade (TEBET, 2007, p. 396).

Assim, como na LREF o que se busca é a preservação da empresa, para que o devedor tenha direito à concessão de sua recuperação, não basta que ele preencha os requisitos estabelecidos no art. 48 da $\mathrm{LREF}^{131}$ (como ocorria na revogada Lei de Falências, pois

\footnotetext{
128 "Preservação da empresa: em razão de sua função social, a empresa deve ser preservada sempre que possível, pois gera riqueza econômica e cria emprego e renda, contribuindo para o crescimento e o desenvolvimento social do País. Além disso, a extinção da empresa provoca a perda do agregado econômico representado pelos chamados intangíveis como nome, ponto comercial, reputação, marcas, clientela, rede de fornecedores, know-how, treinamento, perspectiva de lucro futuro, entre outros" (TEBET, 2007, p. 394).

129 "Separação dos conceitos de empresa e empresário: a empresa é o conjunto organizado de capital e trabalho para a produção ou circulação de bens ou serviços. Não se deve confundir a empresa com a pessoa natural ou jurídica que a controla. Assim, é possível preservar uma empresa, ainda que haja a falência, desde que se logre aliená-la a outro empresário ou sociedade que continue sua atividade em bases eficientes" (TEBET, 2007, p. 394).

130 "Recuperação das sociedades e empresários recuperáveis: sempre que for possível a manutenção da estrutura organizacional ou societária, ainda que com modificações, o Estado deve dar instrumentos e condições para que a empresa se recupere, estimulando, assim, a atividade empresarial" (TEBET, 2007, p. 394).

131 LREF, Art. 48. Poderá requerer recuperação judicial o devedor que, no momento do pedido, exerça regularmente suas atividades há mais de 2 (dois) anos e que atenda aos seguintes requisitos, cumulativamente: I - não ser falido e, se o foi, estejam declaradas extintas, por sentença transitada em julgado, as responsabilidades daí decorrentes; II - não ter, há menos de 5 (cinco) anos, obtido concessão de
} 
para o deferimento da concordata preventiva era preciso apenas que o devedor cumprisse certas exigências legais), mas é necessário demonstrar a viabilidade econômica da empresa, e obter a aprovação do plano de recuperação pelos credores, sob pena de ser decretada sua falência.

COELHO (2008, p. XXXIX), ao expor as principais novidades da Lei de Recuperação de Empresas e Falência, ressalta que

a) a concordata é um direito a que tinha acesso todo empresário que preenchesse as condições da lei, independentemente da viabilidade de sua recuperação econômica, mas à recuperação judicial só tem acesso o empresário cuja atividade econômica possa ser reorganizada; $b$ ) enquanto a concordata produz efeito somente em relação aos credores quirografários, a recuperação judicial sujeita todos os credores, inclusive os que titularizam privilégio ou preferência (a única limitação legal é o pagamento das dívidas trabalhistas em no máximo 1 ano), exceto os fiscais (que devem ser pagos ou parcelados antes da concessão do benefício); c) o sacrifício imposto aos credores, na concordata, já vem definido na lei (dividendo mínimo) e é da unilateral escolha do devedor, ao passo que na recuperação judicial, o sacrifício, se houver, deve ser delimitado no plano de recuperação, sem qualquer limitação legal, e deve ser aprovado por todas as classes de credores.

Exatamente porque a LREF adotou por princípio a preservação da empresa, seu art. 47 expressamente dispõe que "a recuperação judicial tem por objetivo viabilizar a superação da situação de crise econômico-financeira do devedor, a fim de permitir a manutenção da fonte produtora, do emprego dos trabalhadores e dos interesses dos credores, promovendo, assim, a preservação da empresa, sua função social e o estímulo à atividade econômica."

E para que esses objetivos possam ser alcançados, tem fundamental importância a atuação do devedor e de seus administradores, os quais a LREF, seguindo a tradição de nosso Direito positivo, mantém na condução da atividade empresarial (art. 64, caput), justificando-se, assim, o exame, ainda que superficial, do conceito de devedor na LREF,

recuperação judicial; III - não ter, há menos de 8 (oito) anos, obtido concessão de recuperação judicial com base no plano especial de que trata a Seção V deste Capítulo; IV - não ter sido condenado ou não ter, como administrador ou sócio controlador, pessoa condenada por qualquer dos crimes previstos nesta Lei. Parágrafo único. A recuperação judicial também poderá ser requerida pelo cônjuge sobrevivente, herdeiros do devedor, inventariante ou sócio remanescente. 
bem como dos possíveis efeitos da recuperação judicial para a sociedade empresária e seus administradores.

Antes, porém, é necessário destacar que o art. 48, inc. IV, da LREF dispõe que se o administrador da sociedade empresária tiver sido condenado pela prática de crime falimentar, o devedor estará impedido de requerer a recuperação judicial. O objetivo desta proibição, segundo SIMIONATO (2008, p. 132), é atribuir transparência ao processo de recuperação judicial, pois a eventual administração de uma empresa em recuperação por quem foi condenado pela prática de crime falimentar é um indício de uso indevido do benefício legal (COELHO, 2008, p. 124).

Esta proibição da lei foi duramente criticada por diversos autores, tais como LOBO (2007, p. 133), BEZERRA FILHO (2007, p. 139) e CAMPINHO (2008, p. 133), segundo os quais a lei confunde a empresa com o empresário, punindo a primeira em virtude de atos praticados pelo segundo, de modo que mesmo sendo perfeitamente superáveis as dificuldades econômico-financeiras da sociedade, os problemas pessoais do administrador impedirão a recuperação, e o devedor poderá vir a ter sua falência decretada.

Por esta razão, MARZAGÃO (2007, p. 91) destaca que o impedimento de requerer a recuperação judicial violaria a norma do art. 47 da LREF, que é o cerne da nova legislação, e consagra a preservação da empresa, sua função social e o estímulo à atividade econômica, independentemente de questões pessoais do administrador.

A realidade, porém, é que a proibição da sociedade empresária, cujo administrador tenha sido condenado pela prática de crime falimentar, de pedir a recuperação judicial, não constitui um retrocesso na legislação.

Isto porque, como o art. 1.011, $\S 1^{\circ}$, do Código Civil (aplicável às sociedades limitadas regidas supletivamente pelas normas da sociedade simples) e o art. $147, \S 1^{\circ}$, da Lei $\mathrm{n}^{\mathrm{o}}$ 6.404/76 (incidente sobre as sociedades por ações e as sociedades limitadas regidas supletivamente pelas normas das companhias) proíbem a pessoa condenada pela prática de crime falimentar de administrar sociedades, se o cargo de administrador for exercido por quem tenha sido condenado, o devedor estará violando norma cogente de lei federal. Esta é a razão pela qual estará impedido de requerer a recuperação judicial. 
Assim, se a sociedade for administrada por quem tenha sido condenado pela prática de crime falimentar, o devedor somente poderá requerer a recuperação judicial se, antes de formular o pedido, substituir seu administrador por outro que não tenha sofrido esta condenação (SIMIONATO, 2008, p. 132). Para tanto será necessário, em um momento de crise econômica da empresa, em que os ânimos dos sócios ficam extremamente exaltados, alterar o contrato social (se o administrador da limitada tiver sido nomeado contratualmente) ou realizar reunião de quotistas ou assembleia de acionistas.

De todo modo, AYOUB e CAVALLI (2013, p. 42) destacam que o disposto no inc. IV do art. 48 da LREF tem incidência muito restrita, porquanto

\begin{abstract}
a condenação de administrador de empresa por crime falimentar conduz ao 'impedimento para o exercício de cargo ou função em conselho de administração, diretoria ou gerência das sociedades' empresárias (art. 181, II, da LRF). Tanto que, uma vez transitada em julgado a sentença penal condenatória, 'será notificado o Registro Público de Empresas para que tome as medidas necessárias para impedir novo registro em nome dos inabilitados' (art. 181, § $2^{\circ}$, da LRF). Vale dizer, não haverá a possibilidade de pessoa condenada por crime falimentar integrar a administração ou conselho de sociedades empresárias, o que retira qualquer importância do disposto a esse respeito no inc. IV, art. 48 da LRF.
\end{abstract}

Lembre-se, por fim, com COELHO (2008, p. 124), que se o administrador condenado criminalmente já tiver sido reabilitado, a sociedade por ele administrada poderá requerer a recuperação judicial. Da mesma forma, também não está impedida de requerer a recuperação a sociedade empresária cujo administrador tenha sido denunciado pelo Ministério Público e ainda esteja sendo processado, uma vez que impedir a sociedade de requerer a recuperação nesta situação violaria o princípio da presunção de inocência (SIMIONATO, 2008, p. 132).

\title{
1. A manutenção do administrador e do devedor na gestão da empresa em recuperação judicial
}

Os sujeitos passivos da LREF, como se expôs na Introdução desta dissertação (Capítulo I, supra), são o empresário individual, a empresa individual de responsabilidade limitada (EIRELI), a sociedade empresária em nome coletivo, a sociedade empresária em 
comandita simples, a sociedade empresária limitada, a sociedade empresária em comandita por ações e a sociedade por ações (que sempre é empresária, qualquer que seja seu objeto).

Porque sujeitos à LREF, essas pessoas poderão vir a ter suas falências decretadas, mas, em contrapartida, poderão se valer dos procedimentos de recuperação judicial e extrajudicial para superar eventuais crises econômico-financeiras, de modo a evitar a decretação da falência, preservando-se a empresa, mantendo-se a fonte produtora e o emprego dos trabalhadores.

Especificamente em relação à recuperação, o caput do art. 64 da LREF expressamente prescreve que "o devedor ou seus administradores serão mantidos na condução da atividade empresarial, sob fiscalização do Comitê, se houver, e do administrador judicial", decorrendo dessa norma legal que a apresentação do pedido, a ordem de processamento e a homologação do plano de recuperação não importam no afastamento do devedor nem de seus administradores.

Expondo o processo legislativo de aprovação da LREF, FONSECA (2009, p. 428) destaca que a redação original do Projeto de Lei de Falências (Projeto de Lei $n^{\circ}$ 4.376) previa o afastamento automático do devedor ou de seus administradores, pois o art. 16, inc. I, do Projeto dispunha que, deferido o pedido de recuperação, o juiz procederia ao sorteio de administrador judicial para gerir a empresa, exceto se se tratasse (a) de empresas de médio e pequeno porte, cujas receitas fossem insuficientes para o pagamento da remuneração do administrador judicial (art. 16, $\S 5^{\circ}$, do Projeto), hipótese na qual o devedor ou os administradores seriam mantidos, ou (b) de devedor individual (art. 16, $\S 6^{\circ}$, do Projeto) $)^{132}$.

E prossegue FONSECA (2009, p. 428) esclarecendo que o referido Projeto de Lei $\mathrm{n}^{\mathrm{o}} 4.376$ foi alterado a partir de Projeto Substitutivo apresentado pelo Deputado Osvaldo Biolchi, cujo art. 65 contemplava a manutenção do devedor ou seus

\footnotetext{
${ }^{132}$ Art.16 - Deferindo o pedido de recuperação, cabe ao juiz: I - sortear, desde logo, o administrador judicial da empresa; (...) $\S 5^{\circ}$ Não serão substituídos, nos cargos sociais, os diretores e administradores das pessoas juridicas de natureza civil ou comercial, de pequeno porte, e das de médio porte, cuja receita não permita o pagamento da remuneração do administrador judicial. $\S 6^{\circ} \mathrm{O}$ devedor individual prosseguirá no exercício de sua atividade, podendo o juiz nomear administrador não constante da lista a que se refere a art. 227, se entender necessário.
} 
administradores, exceto no caso de ilícito civil ou penal. As posteriores alterações do Projeto Substitutivo mantiveram a continuidade da gestão do devedor por seus administradores, sendo que a principal novidade refere-se ao gestor judicial, a quem será atribuída a responsabilidade pela condução da empresa no caso de afastamento do devedor.

Esclareça-se apenas que o Projeto de Lei $n^{\circ} 4.376$, tal como publicado no Diário do Congresso Nacional de 22 de fevereiro de 1994, e destacado por FONSECA (2009, p. 428), efetivamente previa o sorteio de administrador judicial para gerir a empresa na hipótese de recuperação judicial. Entretanto, o procedimento da recuperação judicial, no Projeto, não tinha por finalidade permitir a superação de problemas econômico-financeiros do devedor com o objetivo de evitar a decretação da sua falência.

Ao contrário, o art. $9^{\circ}$ do Projeto previa que "o devedor cuja falência for decretada pode requerer a continuação do negócio, que vise à sua recuperação", de modo que o administrador judicial teria por função gerir a empresa falida durante a autorização de continuação dos negócios. O procedimento que o Projeto de Lei no 4.376 estabelecia para que o devedor pudesse superar suas dificuldades econômicas e evitar a falência era a concordata, dispondo o art. 36 que “o concordatário e o sócio ilimitadamente responsável conservam a administração dos seus bens, sob a físcalização do comissário, e com as limitações impostas por esta lei." 133

Daí que, desde sua versão original, o Projeto de Lei ${ }^{\circ} 4.376$, do qual decorreu a LREF, previa, como regra, a manutenção do devedor e de seus administradores na condução da empresa em crise que se valesse do procedimento da concordata para superar as dificuldades econômico-financeiras. Apenas excepcionalmente é que o devedor e/ou seus administradores seriam afastados.

\footnotetext{
${ }^{133}$ Embora na versão original do Projeto de Lei $n^{\circ} 4.376$ se dispusesse que o concordatário seria mantido na condução da atividade empresarial, o art. 46 acrescentava que "o devedor será privado da administração dos seus bens, até o trânsito em julgado da sentença que julgar cumprida a concordata, se: I - ocultar bens; II omitir informações que deva prestar ao juiz ou ao comissário; III - prestar informação falsa; IV - praticar ato doloso em prejuízo dos credores. $\S 1^{\circ}$ - O comissário ou qualquer credor podem requerer a medida prevista neste artigo. $\S 2^{\circ}$ - Ouvido o devedor, no prazo de três dias, o juiz, em cinco dias, proferirá decisão. Se deferirir a medida, sorterá o administrador judicial e fixará a remuneração, atendendo à situação dos bens e às dificuldades do exercício da função. $\S 3^{\circ}$ - O administrador judicial responde pelos prejuízos que por dolo ou culpa, causar ao devedor."
} 
Crítica, GUIMARÃES (2007, p. 160) ressalta que muitas vezes a crise não decorre de atos ilícitos cometidos pelos administradores, mas de equívocos na condução dos negócios (tais como a escolha de estratégias), bem por isso

\begin{abstract}
afastar o devedor ou seus administradores da gestão das sociedades (durante o processo de recuperação judicial) ou impor-lhes vedações no exercício das atividades empresariais, a exemplo de alienar ou onerar bens do ativo sem autorização judicial, são medidas insuficientes para garantir a preservação da empresa. E por que isso? Se demonstrado ficar que o devedor ou seus administradores foram os responsáveis pela situação financeira da empresa, tanto que foram substituídos como entregar aos mesmos administradores a condução do negócio, após encerrado o processo de recuperação! Todo o esforço empreendido no saneamento e reorganização da empresa pode ser perdido [...]
\end{abstract}

MUNHOZ (2007, p. 309) concorda que a manutenção dos administradores da sociedade em recuperação judicial tem alguns aspectos negativos, pois se o Judiciário tivesse poderes para nomear um administrador para gerir a empresa, esta poderia ter seus custos de transação reduzidos, e seria um estímulo à obtenção de resultados favoráveis a toda a sociedade, e não apenas a um determinado grupo.

No entanto, prossegue MUNHOZ (2007, p. 310), embora a manutenção dos administradores possa ter como consequência um incremento nos custos de transação, a não substituição traz mais benefícios do que desvantagens, destacando-se:

(i) incentiva o devedor a não postergar a distribuição do pedido de recuperação, (ii) não gera ao devedor aversão ao crédito, (iii) evita a adoção de projetos com risco excessivo, na medida em que o devedor, na recuperação, pode obter para si uma parcela do valor da empresa, (iv) possibilita a elaboração do plano por quem detém mais informações sobre a empresa, e (v) estimula a reorganização, na medida em que confere poder de barganha ao devedor. A manutenção do devedor e seus administradores na condução do negócio pode resultar, portanto, em resultados ex ante (itens I a III, supra) e ex post (itens IV e V, supra) positivos.

Ademais, como mostra a experiência norte-americana, durante o período em que esteve em vigor o Chapter $X$ com a redação que lhe foi dada pelo Chandler Act, o qual previa o afastamento compulsório dos administradores e a nomeação de trustee para gerir a empresa devedora, houve sensível redução na quantidade de processos de recuperação, o 
que comprova ser mais efetiva a lei concursal que não prevê, como regra geral, o afastamento e a substituição do administrador do devedor que pede recuperação judicial.

Tanto assim é que, ao discutir os benefícios da manutenção do devedor na gestão da empresa em recuperação, concluiu o relatório da House of Representatives dos Estados Unidos que

\begin{abstract}
the public and the creditors will not necessarily be harmed if the debtor is continued in possession in a reorganization case, as has been demonstrated under current Chapter XI. In fact, very often the creditors will be benefited by continuation of the debtor in possession, both because the expense of a trustee will not be required and the debtor, who is familiar with his business, will be better able to operate it during the reorganization case. A trustee frequently has to take time to familiarize himself with the business before the reorganization can get under way. Thus, a debtor continued in possession may lead to a greater likelihood of sucess in the reorganization. Moreover, the need for reorganization of a public company today often results from simples business reverses, not from any fraud, dishonesty, or gross, mismanagement on the part of debtor's management. Even if the cause is fraud or dishonesty, very frequently the fraudulent management will have been ousted shortly before the filing of the reorganization case, and the new management, very capable of running the business, should not be ousted by a trustee because of the sins of former management. ${ }^{134}$
\end{abstract}

Ademais, se, de um lado, a manutenção dos administradores e do devedor pode, eventualmente, gerar insatisfação e desconfiança dos credores (ou de parte deles) quanto à viabilidade da recuperação da empresa, de outro lado, é necessário destacar que o processo de recuperação tem como consequência, um incremento nos deveres fiduciários dos administradores, com a finalidade de "permitir a manutenção da fonte produtora, do em-

\footnotetext{
${ }^{134}$ Rep. $\mathrm{n}^{\mathrm{o}}$ 595, $95^{\text {th }}$ Cong., $1^{\text {st }}$ Sess, p. 233, in CEREZETTI, 2012, p. 390, nota de rodapé $\mathrm{n}^{\mathrm{o}}$ 391. Tradução livre: o público e os credores não serão necessariamente prejudicados se o devedor continuar na gestão durante o processo de reorganização, como foi demonstrado na vigência do Chapter XI. Na verdade, muitas vezes os credores serão beneficiados pela continuação da gestão do devedor, tanto porque não será necessário gastar com um administrador e o devedor, que está familiarizado com o seu negócio, será mais capaz de gerilo durante a reorganização. O trustee frequentemente necessita tempo para se familiarizar com o negócio antes do início da reorganização. Assim, a manutenção da gestão do devedor pode levar a uma maior probabilidade de sucesso da reorganização. Além disso, a necessidade de reorganização de uma empresa, hoje, geralmente decorre de simples revés empresarial, não de fraude, desonestidade, ou gestão fraudulenta por parte dos administradores do devedor. Mesmo no caso de fraude ou desonestidade, muito frequentemente a gestão fraudulenta é afastada pouco antes da apresentação do pedido de reorganização, de modo que a nova gestão, capaz de gerir o negócio, não deve ser substituída por um administrador por culpa de atos da gestão anterior.
} 
prego dos trabalhadores e dos interesses dos credores, promovendo, assim, a preservação da empresa, sua função social e o estímulo à atividade econômica" (LREF, art. 47) ${ }^{135}$.

Bem por isso, a LREF atribui não apenas ao administrador judicial (art. 22, inc. II, “a" e "b"), mas também ao comitê de credores (art. 27, inc. II, "a" e "b"), a função de fiscalizar as atividades do devedor e o cumprimento do plano de recuperação aprovado pelos credores e homologado pelo juiz, o que também abrange a fiscalização do cumprimento, pelos administradores do devedor, de seus deveres fiduciários.

Daí que a LREF, ao manter o devedor e seus administradores na condução da empresa em recuperação judicial está adequada à realidade, visto que o afastamento automático dos administradores, além de presumir que a crise decorre da prática de ilícitos (civil e penal) pelos administradores e pelo devedor, o que nem sempre corresponde à realidade, e pode dar margem a injustiças, não é o meio mais eficiente de possibilitar o soerguimento do devedor.

É de se acrescentar também que a possibilidade de afastamento dos administradores e do devedor, nas hipóteses de que tratam os incisos do art. 64 da LREF, é de fundamental importância porque permite, nos casos de crime, fraude, negligência, ou grave incompetência administrativa, separar a sorte da empresa da do empresário, de modo a preservar a primeira, com vistas a alcançar a superação da crise econômico-financeira, a manutenção da fonte produtora e dos empregos (MUNHOZ, 2007, p. 310).

\section{Introdução ao conceito de devedor na LREF}

A recuperação judicial, como se viu, não implica a automática destituição dos administradores da sociedade empresária, nem o afastamento do devedor, que permanecem

\footnotetext{
${ }^{135}$ Foi o que decidiu o TJDFT, no Agravo de Instrumento n 20090020157141, $1^{\text {a }}$ Turma Cível, Relator Desembargador Flávio Rostirola, j. 16.12.2009, v.u.: "Nesse sentido, a iniciativa do processo de recuperação judicial bem como o seu cumprimento restaram incumbidos ao devedor empresário, para que este, da melhor maneira possível, cumpra o plano de recuperação apresentado, seja pessoalmente, seja em colaboração com o administrador judicial, conforme previsto no artigo 64 da Lei $\mathrm{n}^{\circ} 11.101 / 2005$. Ao devedor, assim, durante o processo de recuperação judicial, faculta-se a tomada de decisões que melhor atendam aos objetivos da recuperação, entre os quais, a viabilidade das atividades empresariais e a satisfação dos credores. Cabe ao devedor empresário, pois, decidir qual o melhor caminho a ser trilhado na busca pela satisfação dos créditos, inclusive aqueles referentes à atividade cotidiana da empresa, entre os quais se situa o pagamento de honorários advocatícios."
} 
na gestão da empresa, sob a fiscalização do administrador judicial e, se houver, do comitê de credores, sendo-lhes impostos, também, algumas restrições na condução do negócio, tais como as limitações à alienação ou oneração de bens ou direitos de seu ativo permanente (LREF, art. 66).

Isso não obstante, se configurada a prática de qualquer um dos atos indicados nos incisos do art. 64 da $\mathrm{LREF}^{136}$, os administradores do devedor poderão vir a ser afastados, hipótese na qual seus sucessores serão escolhidos na forma estabelecida pelos sócios ou acionistas nos atos constitutivos do devedor (contrato social se limitada e estatuto social se sociedade por ações), nos expressos termos do parágrafo único do já referido art. 64 da LREF.

$\mathrm{O}$ art. 65 da lei concursal, por sua vez, acrescenta que se o devedor, não os administradores, for afastado pelo juiz, os credores, reunidos em assembleia geral, deliberarão "sobre o nome do gestor judicial, que assumirá a administração das atividades do devedor, aplicando-se-lhe, no que couber, todas as normas sobre deveres, impedimentos e remuneração do administrador judicial."

Em outras palavras, se, em virtude da prática dos atos indicados nos incisos do art. 64 da LREF, os administradores do devedor forem afastados, novos serão escolhidos na forma ajustada pelos sócios nos atos constitutivos da sociedade; entretanto, se qualquer um dos atos descritos nos incisos do referido art. 64 for praticado pelo próprio devedor, ele, devedor, é que será afastado, e os credores elegerão gestor judicial para assumir justamente a "administração das atividades do devedor".

\footnotetext{
${ }^{136}$ As condutas que importam no afastamento do devedor ou de seus administradores serão examinadas no Capítulo IV infra, mas para facilitar o exame são aqui transcritos: "I - houver sido condenado em sentença penal transitada em julgado por crime cometido em recuperação judicial ou falência anteriores ou por crime contra o patrimônio, a economia popular ou a ordem econômica previstos na legislação vigente; II - houver indícios veementes de ter cometido crime previsto nesta Lei; III - houver agido com dolo, simulação ou fraude contra os interesses dos credores; IV - houver praticado qualquer das seguintes condutas: a) efetuar gastos pessoais manifestamente excessivos em relação à sua situação patrimonial; b) efetuar despesas injustificáveis por sua natureza ou vulto, em relação ao capital ou gênero do negócio, ao movimento das operações e a outras circunstâncias análogas; c) descapitalizar injustificadamente a empresa ou realizar operações prejudiciais ao seu funcionamento regular; d) simular ou omitir créditos ao apresentar a relação de que trata o inciso III do caput do art. 51 desta Lei, sem relevante razão de direito ou amparo de decisão judicial; V negar-se a prestar informações solicitadas pelo administrador judicial ou pelos demais membros do Comitê; VI - tiver seu afastamento previsto no plano de recuperação judicial."
} 
Da interpretação literal dos referidos arts. 64 e 65 da LREF decorre, assim, que devedor e administradores não se confundem, pois no caso de recuperação judicial ambos são, em regra, mantidos, e, na hipótese de serem eles afastados, seus substitutos são diversos: novos administradores escolhidos na forma dos atos societários ou gestor judicial eleito pelos credores.

Por outro lado, o art. $1^{\circ}$ da LREF dispõe que "esta lei disciplina a recuperação judicial, a recuperação extrajudicial e a falência do empresário e da sociedade empresária, doravante referidos simplesmente como devedor", acrescentando o art. 190 do mesmo diploma legal que "todas as vezes que esta lei se referir a devedor ou falido, compreenderse-á que a disposição também se aplica aos sócios ilimitadamente responsáveis.”

Interpretando-se, também literalmente, esses dois dispositivos legais, concluise que devedor, para os efeitos da LREF, é o empresário individual, a sociedade empresária e os sócios de responsabilidade ilimitada, não abrangendo os sócios de responsabilidade limitada, como é o caso dos acionistas das sociedades por ações e dos quotistas das sociedades limitadas.

Esse, porém, não é o entendimento de FONSECA (2009, p. 448), para quem devedor, para efeito de afastamento e consequente substituição pelo gestor judicial eleito pelos credores em assembleia geral, é apenas o empresário individual, não a sociedade empresária, pois (a) o parágrafo único do art. 64 trata das consequências do afastamento do administrador de sociedade empresária (porquanto o substituto será escolhido "na forma prevista nos atos constitutivos do devedor"), e (b) durante o processo legislativo que deu origem à LREF, foi suprimido do projeto o dispositivo que expressamente estabelecia o afastamento do controlador.

Em consequência, prossegue FONSECA (2009, p. 448), como o empresário individual não possui "instrumento pré-estabelecido" (ou, nos termos da lei, "atos constitutivos"), e como a lei não prevê o afastamento dos controladores, o gestor judicial substitui apenas e tão-somente o empresário individual, "que exerce suas atividades pessoalmente e em nome próprio, confundindo-se seu patrimônio com o da empresa." 
A única exceção admitida pelo autor para a nomeação de gestor judicial no processo de recuperação judicial de sociedade empresária ocorre no caso de não haver nenhuma pessoa natural que preencha os requisitos estabelecidos nos atos constitutivos para substituir os administradores afastados. Neste caso, seria obrigatória a nomeação de gestor judicial para conduzir a empresa devedora ${ }^{137}$.

De modo similar, CAMPINHO (2008, p. 153) sustenta que passível de afastamento são os administradores (substituídos na forma do parágrafo único do art. 64 da LREF, não pelo gestor judicial de que trata o art. 65) e o devedor "pessoa natural", ou seja, o empresário individual, que será substituído pelo gestor judicial eleito pelos credores em assembleia geral.

Acrescenta CAMPINHO (2008, p. 153), entretanto, que o devedor "pessoa jurídica" poderá vir a ser afastado, e substituído pelo gestor judicial, na hipótese de não se mostrar factível a substituição dos administradores na forma ajustada no contrato social: trata-se do caso de sociedade limitada (a) em que todos os sócios são administradores, (b) cujo contrato social não admite administrador não sócio e (c) todos os sóciosadministradores encontram-se incursos nas hipóteses de que tratam os incisos do art. 64. Neste caso, porque não é possível a nomeação de administrador substituto na forma estabelecida no contrato social, a solução é o afastamento da própria pessoa jurídica e a convocação de assembleia geral de credores para a escolha de gestor judicial.

O entendimento de que devedor, nos termos do art. 65 da LREF, é apenas o empresário individual (e excepcionalmente a sociedade empresária na qual não se mostra factível a nomeação de novos administradores na forma de seus atos societários), não parece ser, contudo, a mais correta. Isto porque, as condutas descritas nos incisos do art. 64, e que justificam o afastamento dos administradores e do devedor, são todas praticadas por pessoas naturais, o que inclui não apenas o empresário individual, mas também os

\footnotetext{
${ }^{137}$ Para explicar a exceção, FONSECA (2009, p. 448) cita os seguintes exemplos: "seria a situação de uma sociedade limitada, cujos atos constitutivos prevejam que os administradores serão necessariamente sócios, e todos os sócios estejam impedidos nos termos do art. 64. Outra possibilidade seria a de uma sociedade em nome coletivo ou em comandita simples, com todos os sócios ou todos os comanditados impedidos. Nesses casos, seria o próprio devedor, ou seja, a sociedade empresária como um todo, que seria afastada da administração, por impossibilidade material de conduzir o negócio, com consequente nomeação de gestor judicial. Ainda assim, se a sociedade empresária sanear o vício - por alteração contratual, admissão de novo sócio ou outro meio lícito - e oferecer administrador hábil a assumir a empresa, não há razão para afastá-la da administração ou para impedir seu retorno no caso de já haver um gestor judicial em atividade."
} 
administradores, os sócios e acionistas da sociedade empresarial devedora. Em consequência, se o ato que justifica o afastamento for praticado pelos administradores, serão eles afastados e substituídos por outros, nomeados na forma prevista no contrato ou no estatuto social. Entretanto, se o ato for praticado pelos sócios ou acionistas da sociedade empresária, não se justifica a "manutenção" desses sócios e/ou da sociedade devedora, impondo-se a nomeação do gestor judicial.

De fato, se os sócios ou acionistas implementam atos que se subsumem, por exemplo, na hipótese descrita na alínea "c" do inc. IV do art. 64 da LREF, isto é, "descapitalizar injustificadamente a empresa ou realizar operações prejudiciais ao seu funcionamento regular", o devedor (quer seja ele a sociedade empresária, quer sejam eles os sócios ou acionistas) deverá ser afastado e substituído pelo gestor judicial.

E o afastamento, no exemplo acima, justifica-se também porque no Brasil, como se sabe, prevalece o controle concentrado, de modo que os administradores, no mais das vezes, ou são os próprios sócios (ou acionistas) ou estão a eles subordinados, daí decorrendo que, se o devedor (quer seja a sociedade empresária, quer sejam seus sócios e acionistas) não for afastado, as pessoas que praticaram os atos justificadores da substituição continuarão, ainda que indiretamente, conduzindo a atividade empresarial, o que não parece ser a melhor interpretação do dispositivo legal. O termo devedor a que se refere o art. 65 da LREF, por essas razões, não pode se limitar ao empresário individual e, apenas excepcionalmente, à sociedade empresária devedora.

Bem por isso, esclarece MUNHOZ (2007, p. 307) $)^{138}$ :

adotando-se uma interpretação literal, infere-se que o art. 64, ao empregar a expressão devedor, aplica-se: (i) no caso do empresário individual, à pessoa natural que exerce o negócio; (ii) no caso das sociedades de responsabilidade ilimitada, personificadas, à própria sociedade e aos sócios ilimitadamente responsáveis; (iii) no caso das sociedades de responsabilidade limitada personificadas, à própria sociedade, e não aos seus sócios.

${ }^{138}$ O comentário de MUNHOZ está na segunda edição, de 2007, antes, portanto, da edição da Lei $n^{\circ} 12.441$, de 11 de julho de 2011, que entrou em vigor no dia 10 de janeiro de 2012, que introduziu no ordenamento jurídico nacional a empresa individual de responsabilidade limitada (EIRELI). 
Isso não obstante, o próprio MUNHOZ (2007, p. 307) acrescenta que a lei não deveria estabelecer o afastamento do devedor, mas do acionista controlador, pois é ele quem, de fato, conduz a empresa. Ademais, afastar o devedor importa alijar a pessoa jurídica sociedade empresária devedora da gestão da empresa o que, além de prejudicar os sócios não controladores (acionistas minoritários) - que dificilmente terão praticado qualquer ato irregular que se subsuma nas hipóteses do art. 64 da LREF -, fará com que o gestor judicial assuma a condução dos negócios de "fora da estrutura societária".

Daí que, prossegue MUNHOZ (2007, p. 307), “em se tratando de sociedade personificada de responsabilidade limitada, a melhor interpretação dos arts. 64 e 65 é que, em vez de devedor, deve-se ler sócio controlador”. Em consequência,

uma vez decidido o afastamento dos administradores do devedor, sem que se tenha determinado o afastamento de seus sócios controladores, a substituição dos primeiros deve ser feita nos termos dos atos constitutivos da sociedade, ou de acordo com o que for definido no plano de recuperação, se a substituição for definida por este.

Entretanto, se o próprio "devedor" for afastado, quem será alijado serão os sócios controladores, não a própria sociedade devedora, hipótese na qual será nomeado um Gestor Judicial, na forma definida do art. 65 da LREF (MUNHOZ, 2007, p. 307)

Nesse mesmo sentido posicionou-se CEREZETTI (2012, p. 405), para quem o termo devedor, nos arts. 64 e 65 da LREF, deve ser interpretado como acionista controlador, único que poderia ser afastado e substituído pelo gestor judicial, de modo a preservar íntegros os direitos dos sócios que não detém o poder de controle da sociedade empresária devedora ${ }^{139}$.

\footnotetext{
${ }^{139}$ Explicando as divergências existentes na interpretação do termo devedor, CEREZETTI (2012, p. 403) informa que "uma interpretação, conforme indicado acima, é a de que o devedor significaria o acionista controlador, e, assim, o gestor, que seria indicado pelos credores, ocuparia o lugar do controlador na estrutura societária. Essa seria uma maneira de preservar os direitos societários dos acionistas minoritários. Caberia, então, ao gestor participar de assembleias gerais de acionistas. Outra leitura do artigo indicaria que devedor significa a própria sociedade, e, portanto, toda a estrutura societária será afastada, e o gestor passaria a atuar como se fosse o próprio devedor. Por meio dessa via, o gestor substituiria os próprios órgãos societários e os acionistas veriam seus direitos obstruídos. Essa parece, contudo, ser uma visão bastante agressiva do instituto."
} 
Esta posição, contudo, é criticada por VERÇOSA $\left(2006^{\mathrm{a}} \text {, p. 30 }\right)^{140}$ que, adotando posição similar a de FONSECA (2009, p. 448), sustenta que o termo devedor empregado especificamente no art. 64 da LREF significa empresário individual, jamais sociedade empresária, de modo que sequer por hipótese o termo devedor poderia ser interpretado como controlador.

Para SIMIONATO (2008, p. 192), por outro lado, o termo devedor não se refere à sociedade empresária, mas a seus sócios ou acionistas, que poderão vir a ser afastados da condução da empresa, o que, para o autor, seria temerário, porquanto não poderiam eles ser privados de seus direitos de sócio, exercidos mediante o direito de voto para determinar-se a vontade social.

A crítica de SIMIONATO (2008, p. 193) ao afastamento dos sócios e acionistas, e sua substituição pelo gestor judicial, refere-se ao fato de que "se o sócio for destituído de suas funções administrativas (direitos) ele será também, por consequência, desconstituído dos seus deveres", de modo que se vier a ser decretada a falência do devedor cuja empresa está sendo conduzida pelo gestor judicial, a responsabilidade seria deste último, não dos sócios ou acionistas afastados.

De modo diverso, PIMENTA (2006, p. 177) destaca que sujeitos ao afastamento e substituição pelo gestor judicial, eleito pelos credores, são tanto os administradores quando os sócios da pessoa jurídica empresária devedora, motivo pelo qual ao gestor judicial atribui-se a responsabilidade "pela administração e/ou controle da sociedade empresária em recuperação (art. 65)"141.

\footnotetext{
${ }^{140}$ Afirma textualmente VERÇOSA (2006 , p. 30) que "durante o procedimento de recuperação judicial, o devedor (empresário individual) ou os administradores da sociedade empresária estão submetidos à regra geral de sua permanência na gestão do estabelecimento comercial ou da sociedade comercial correspondentes, conforme o caso, somente podendo ser afastados nas condições legalmente expressas. E, na medida em que o controlador permanece durante a recuperação judicial no regular exercício de suas atribuições (exclusivamente o uso do direito de voto nas Assembléias-Gerais), cujos limites vieram temporariamente a ser afetadas pelos termos do plano de recuperação aprovado, não se pode falar em seu afastamento. Afastados, conforme o caso, serão o empresário ou os administradores da sociedade empresária que se encontrarem em uma das situações predeterminadas no art. 64 da LREF."

${ }^{141}$ PIMENTA (2006, p. 177; e 2008, p. 17) acrescenta ainda que "o gestor judicial tem não apenas o dever de exercer todos os atos inerentes à administração (quando substitui os administradores) ou o controle (quando vier a substituir os sócios) da sociedade em recuperação."
} 
Igualmente, COELHO (2008, p. 175) ressalta que estão sujeitos a afastamento tanto os administradores, mediante a destituição de seus cargos, quanto os sócios e acionistas controladores, de quem será suprimido o direito de voto nas assembleias gerais da sociedade empresária em recuperação.

Comentando o art. 21 da LREF, que trata do administrador judicial, PENTEADO (2009, p. 161) critica a falta de rigor sistemático da legislação e informa que o gestor judicial, "verdadeiro administrador judicial da empresa em recuperação", é nomeado apenas nos casos de afastamento dos administradores, do próprio devedor e do acionista controlador, acrescentando que se se tratar dos administradores, o substituto deve ser escolhido na forma dos atos constitutivos da sociedade ou de acordo com o que constar do plano de recuperação, de modo que o gestor judicial, neste caso, somente será eleito se as regras de direito societário não possibilitarem a nomeação dos sucessores.

Como se percebe, embora a interpretação literal das normas da LREF conduza à conclusão de que devedor, sujeito a afastamento e substituição pelo gestor judicial, são apenas o empresário individual, a sociedade empresária (cujos sócios poderão ter responsabilidade limitada ou ilimitada) e os sócios de responsabilidade ilimitada, há divergência doutrinária quanto à interpretação do termo devedor, sendo que especificamente em relação às sociedades empresárias de responsabilidade limitada (únicas objeto do presente estudo em razão de suas relevâncias para a economia brasileira), a divergência está se "devedor" refere-se à própria sociedade, a todos os seus sócios (ou acionistas), ao acionista (ou sócio) controlador, ou aos seus administradores.

Neste ponto, para que se possa aferir qual parece ser a melhor interpretação do termo devedor a que se referem os arts. 64 e 65 da LREF, faz-se necessário analisar, ainda que superficialmente, quem é o controlador, ou seja, o "sócio com poderes suficientes para decidir o destino da sociedade" (FRANCO e SZTAJN, 2008, p. 250), e quem são os administradores das sociedades empresárias limitadas e das sociedades por ações (únicos tipos societários analisados nesta dissertação). 


\section{O controlador}

Os diversos sistemas de direito societário apresentam características muito diversas. Nos Estados Unidos e no Reino Unido, por exemplo, o sistema está fundado no mercado de capitais, predominando a dispersão acionária. Nos demais países prevalece o sistema fundado no controle concentrado, onde a captação de recursos pelas sociedades depende, fundamentalmente, do sistema financeiro (ex. Alemanha) ou do aporte de recursos pelo Estado ou pelos controladores (ex. Japão, onde predomina o controle familiar das grandes empresas).

As diferenças entre os vários sistemas societários decorrem não apenas de questões econômico-financeiras (destacando-se a eficiência das companhias), mas também de questões políticas, culturais, sociais, históricas e até mesmo familiares.

De acordo com MUNHOZ (2009, p. 119), não existem dados empíricos que comprovem a superioridade de um ou de outro sistema societário, ou de que sociedades com controle disperso sejam mais valiosas ou mais eficientes em relação às que apresentem controle concentrado, pois há muitos fatores que influenciam a eficiência das companhias, tais como questões tecnológicas e legislativas.

O predomínio da dispersão acionária ocorre apenas em relação às "big companies" dos Estados Unidos ${ }^{142}$ e do Reino Unido ${ }^{143}$. Nesse sistema não se verifica a figura do acionista controlador ou grupo de controle, razão pela qual o principal conflito objeto de regulação pelo direito societário é o existente entre os acionistas e os administradores: como impedir que uma administração ineficiente se perpetue no poder através de procurações que lhes são outorgadas para representar os acionistas nas deliberações assembleares.

Nos demais países (inclusive no Brasil) predomina o sistema concentrado, pois as companhias têm sempre um acionista (ou grupo de acionistas) que detém o controle da sociedade. Exatamente por essa razão, no mais das vezes, os administradores são os pró-

\footnotetext{
142 Nos Estados Unidos a dispersão acionária é caracterizada pela elevada quantidade de acionistas pessoas naturais que adotam conduta absenteísta e não participam sequer das assembleias gerais.

${ }^{143}$ No Reino Unido a dispersão das ações ocorre em grau menos intenso do que nos Estados Unidos, e predominam acionistas que acompanham as atividades sociais e participam das deliberações.
} 
prios controladores, ou um seu longa manus, de modo que o principal conflito objeto de regulação pelas normas de direito societário é o existente entre controladores e acionistas minoritários: como limitar ${ }^{144}$ os benefícios privados que o acionista controlador (quer mediante o exercício do poder de controle, quer na administração da companhia) obtém em decorrência da titularidade das ações ${ }^{145}$.

No Brasil, a prevalência do sistema concentrado e a importância do acionista controlador foram reconhecidas pelos próprios autores do Anteprojeto da Lei das S/A, Alfredo Lamy Filho e José Luiz Bulhões Pedreira, que, em contrapartida a esse reconhecimento, com a consequente possibilidade de extração de benefícios decorrentes do exercício desse poder (como o prêmio de controle na hipótese de oferta pública para aquisição de ações), buscaram impor limites à liberdade de atuação do controlador (ou grupo de controle) e responsabilidade pelos atos praticados no exercício desse legítimo poder $^{146}$.

Atualmente, apesar de estar havendo movimento de desenvolvimento do mercado de capitais (com a abertura do capital de muitas companhias e a adesão às regras do Novo Mercado e aos Níveis 1 e 2 de Governança Corporativa $)^{147}$, o predomínio do capital concentrado é inegável.

\footnotetext{
${ }^{144} \mathrm{O}$ objetivo não é extinguir os benefícios privados do controle, mas apenas limitá-lo, uma vez que a própria Lei das Sociedades por Ações atribui valor ao poder de controle pois, por exemplo, na hipótese de Oferta Pública para Aquisição de Ações (conhecida como OPA) o preço pago às ações dos minoritários pode corresponder a $80 \%$ do valor pago às ações do controlador (art. 254-A).
}

${ }^{145}$ Como explica MUNHOZ (2009, p. 119), "no sistema norte-americano, a separação entre propriedade e controle decorre da diluição do capital e de o poder de comando empresarial ser exercido pelos administradores. Assim, o foco central são os problemas que decorrem do conflito entre a coletividade de acionistas e os administradores. No Brasil, ao contrário, o sistema é de um controle fortemente concentrado, de modo que o conflito central a ser regulado é o que se estabelece entre o controlador e não-controladores."

${ }^{146}$ LAMY e PEDREIRA (1997, p. 185/187) destacam que "na fase de criação da empresa, a necessidade da função do empresário-empreendedor, exercida pelo acionista controlador, é óbvia. Nunca ninguém ouviu falar de empresa que nascesse espontaneamente pela reunião de investidores do mercado e administradores pro-fissionais, sem um ou alguns líderes que desempenhassem a função do empreendedor. Mas essa necessidade continua a existir mesmo na empresa aberta que tem 50, 70, 90 ou $95 \%$ do capital em mãos do público investidor (...) Estas considerações explicam por que o Anteprojeto, ao invés de tentar destruir o empresário-empreendedor (e, com ela, a iniciativa privada), adotou, como diretriz, reconhecer sua importância na economia aberta, centrar um grupo de normas em torno de sua figura, assegurar-lhe maior número de opções para organizar a empresa, mas, correlatamente, cobrar-lhe em termos de responsabilidade, empresarial e social, o mau uso que venha a fazer dessa liberdade e do seu poder."

${ }^{147}$ Com a finalidade de atrair investidores, a Bolsa de Valores de São Paulo criou segmentos diferenciados de acordo com os perfis da empresas. Esses segmentos, segundo DONNAGGIO (2012, p. 56), são "Nível 1, Nível 2 e Novo Mercado. O Nível 1 é o menos exigente quanto às práticas de governança, com foco na melhor divulgação de informaçõesda companhia. Seus requisitos são: (i) manutenção de percentual mínimo de $25 \%$ de ações em circulação (free float); (ii) melhoria nas informações prestadas (ITRs, DFPse IANs), (iii) realização de, no mínimo, uma reunião com analistas e investidores por ano; (iv) apresentação de um calen- 


\subsection{Formas de controle}

A doutrina reconhece, fundamentalmente, três formas de controle nas sociedades por ações, a saber: (a) controle interno, que pode ser majoritário ou minoritário; (b) controle gerencial; e (c) controle externo.

O controle externo não está previsto na Lei das Sociedades por Ações e não está fundado na titularidade de ações da companhia, ou seja, não está relacionado ao exercício do direito de voto. Esta forma de controle se configura, fundamentalmente, quando determinado credor (ou grupo de credores), em decorrência de contratos celebrados com a sociedade, exige a adoção de certas condutas ou o respeito a determinados requisitos (geralmente financeiros), sob pena de vencimento antecipado de obrigações contratuais.

Como explica MARTINS (2005, p. 50), a influência do controlador externo decorre, do endividamento e, consequentemente, das obrigações assumidas com credores, obrigações essas que impõem limites à liberdade do devedor, destacando-se restrições à alienações de bens, à distribuição de dividendos e à capacidade de contrair dívidas.

Porque essa forma de controle não é reconhecida pela lei societária brasileira, a exigibilidade ou não do cumprimento dessas obrigações contratuais que limitam a atuação da sociedade, assim como a eventual responsabilidade do "controlador externo", estão reguladas pelas normas do direito das obrigações e, também, pelos princípios gerais da fun-

dário anual da companhia; (v) divulgação de contratos firmados entre companhia e partes relacionadas; (vi) divulgação de negociações realizadas pelos controladores; e (vii) adoção de mecanismos que favoreçam a dispersão do capital quando de distribuição pública de ações. O Nível 2 exige, além dos requisitos do Nível 1, os seguintes: (i) divulgação de demonstrações financeiras com padrão interacional (IFRS ou US GAAP); (ii) conselho de administração com mínimo de cinco membros, sendo $20 \%$ de independentes, e mandato unificado de até dois anos, permitida reeleição; (iii) direito de voto às ações preferenciais em matérias como transformação e incorporação da companhia, e aprovação de contratos entre companhia e empresas do grupo quando deliberados em assembeia geral; (iv) concessão de tad along de $100 \%$ para as ordinárias e de $80 \%$ aos preferencialistas, no mínimo, quando da venda do controle da companhia; (v) realização de oferta pública de aquisição de ações pelo valor econômico nas hipóteses de fechamento do capital ou cancelamento do registro de negociação no Nível; e (vi) adesão à Câmara de Arbitragem do Mercado para resolução de conflitos societários. O segmento mais exigente quanto às práticas de governança dentre os criados pela Bolsa - o Novo Mercado - exige, além dos itens descritos nos Níveis 1 e 2 acima, o tratamento equitativo aos acionistas visto que admite exclusivamente emissão de ações ordinárias, seguindo o princípio 'uma ação - um voto.", 
ção social do contrato e dos negócios jurídicos, assim como os deveres de boa-fé e de probidade, que são exigidos de todos os contratantes ${ }^{148}$.

A segunda forma de controle reconhecida pela doutrina é o denominado controle gerencial, que ocorre nas companhias em que o capital social está disperso (pulverizado) em um grande número de acionistas que adotam postura absenteísta. Neste caso, o controle gerencial surge se os administradores da companhia, valendo-se de procurações outorgadas pelos acionistas para representá-los nas assembleias gerais, "controlam" a sociedade.

Embora a Lei das Sociedades por Ações ${ }^{149}$ estabeleça a possibilidade de o administrador pedir aos acionistas a outorga de mandato para representá-los nas assembleias da companhia, esta forma de controle não se verifica no Brasil, pois além de aqui predominarem sociedades com controle concentrado, a própria Lei $n^{\circ}$ 6.404/76 proíbe o administrador de votar, até mesmo como procurador, na deliberação assemblear que tiver por objeto apreciar as contas e as demonstrações financeiras (art. 134, $\left.\S 1^{\circ}\right)^{150}$.

No Brasil, a única forma de controle reconhecida pela Lei das Sociedades por Ações é o denominado controle interno, cuja ocorrência está relacionada à titularidade de ações e ao efetivo exercício do poder de voto nas deliberações sociais. De fato, para que se configure o controle interno é imprescindível a verificação cumulativa dos dois requisitos estabelecidos no artigo 116:

${ }^{148}$ É importante destacar que essa forma de controle também se manifesta nos processos de recuperação judicial, pois a homologação judicial depende da aprovação, pelos credores, do plano apresentado pelo devedor, de modo que, neste momento de negociação, os credores vêem aumentado o poder de barganha de que dispõem, dada a necessidade do recuperando de fazer concessões para que o plano seja aprovado. Como, porém, não há norma expressa regulando a responsabilidade dos credores, enquanto "controladores externos", por eventuais abusos, suas condutas devem ser examinadas à luz dos princípios gerais, inclusive em relação às eventuais objeções ao plano de recuperação apresentado pelo devedor (PENTEADO, 2007, p. 75).

149 Art. 126. As pessoas presentes à assembleia deverão provar a sua qualidade de acionista, observadas as seguintes normas: [...] $\S 2^{\circ} \mathrm{O}$ pedido de procuração, mediante correspondência, ou anúncio publicado, sem prejuízo da regulamentação que, sobre o assunto vier a baixar a Comissão de Valores Mobiliários, deverá satisfazer aos seguintes requisitos: a) conter todos os elementos informativos necessários ao exercício do voto pedido; b) facultar ao acionista o exercício de voto contrário à decisão com indicação de outro procurador para o exercício desse voto; c) ser dirigido a todos os titulares de ações cujos endereços constem da companhia.

${ }^{150}$ Art. 134. [...] $\S 1^{\circ}$ Os administradores da companhia, ou ao menos um deles, e o auditor independente, se houver, deverão estar presentes à assembleia para atender a pedidos de esclarecimentos de acionistas, mas os administradores não poderão votar, como acionistas ou procuradores, os documentos referidos neste artigo. 
Entende-se por acionista controlador a pessoa, natural ou jurídica, ou o grupo de pessoas vinculadas por acordo de voto, ou sob controle comum, que:

a) é titular de direitos de sócio que lhe assegurem, de modo permanente, a maioria dos votos nas deliberações da assembleia geral e o poder de eleger a maioria dos administradores da companhia; e

b) usa efetivamente seu poder para dirigir as atividades sociais e orientar o funcionamento dos órgãos da companhia.

Controle, assim, é o poder que o acionista (ou grupo de acionistas vinculados por acordo de voto ou controle comum) detém, e exerce, de eleger administradores e dirigir os negócios sociais, ou, como resume BORBA (2007, p. 354), "controla uma sociedade quem detém o poder de comandá-la, escolhendo os seus administradores e definindo as linhas básicas de sua atuação", acrescentando que o poder de controle manifesta-se de forma ostensiva nas assembleias gerais, mas fora delas ele também se apresenta, mas de forma indireta, pela posição de dependência em que se colocam os administradores.

Como controle implica efetivo exercício do poder, o controle interno divide-se em majoritário, quando o acionista ou grupo de acionistas detentor de mais de $50 \%$ das ações é que exerce o poder, e minoritário, que ocorre no caso em que os acionistas majoritários não participam das deliberações e, em consequência, as deliberações são tomadas pelos acionistas titulares de menos de $50 \%$ das ações com direito de voto ${ }^{151}$.

A lei não define, por outro lado, o que se considera "usar" o poder: basta que a vontade do acionista predomine em uma determinada assembleia ou seu voto deve prevalecer em um número mínimo de conclaves? Para BORBA (2007, p. 356), basta que a posição de determinado acionista (ou grupo de acionistas) predomine nas duas últimas assembleias gerais para configurar o controle, uma vez que indicaria permanência. COELHO (2007, p. 280), por sua vez, sustenta que se a vontade de determinado acionista (ou grupo de acionista) prevalecer nas deliberações tomadas nas três últimas assembleias gerais, ele é

\footnotetext{
${ }^{151}$ Comentando o atual movimento de abertura de capital das companhias, COELHO (2007, p. 280) destaca que "desde meados de 2005, tem-se verificado a extraordinária dispersão das ações emitidas por algumas companhias listadas na Bovespa (Lojas Renner, Eternit, Perdigão, Gafisa, Submarino). O poder de controle dessas sociedades anônimas é claramente minoritário e pode chegar a ser, no futuro, gerencial."
} 
o controlador (ou integra o grupo de controle), ainda que não detenha mais da metade do capital social $^{152}$.

Destaque-se, por fim, que embora a figura do controlador conste apenas da Lei das Sociedades por Ações, não do Código Civil, nas limitadas também se constata a ocorrência do predomínio de algum sócio que determina o destino da sociedade, dominando-a.

\subsection{Abuso do poder de controle}

Configurada a existência do controle, tem seu titular o dever de "usar o poder com o fim de fazer a companhia realizar o seu objeto e cumprir sua função social, e tem deveres e responsabilidades para com os demais acionistas da empresa, os que nela trabalham e para com a comunidade em que atua, cujos direitos e interesses deve lealmente respeitar e atender" (Lei n 6.404/76, art. 116, parágrafo único).

E o artigo 117 da mesma lei, por seu turno, contém extensa relação exemplificativa de atos que, se praticados pelo controlador, configuram abuso de poder de contro$1 \mathrm{e}^{153}$, destacando-se: a) orientar a companhia para fim estranho ao objeto social ou lesivo

152 COELHO (2007, p. 280) justifica essa sua posição destacando que "o Banco Central, em 1976, estabeleceu que se considera permanente a manifestação do poder de controle se o acionista titulariza ações que lhe asseguram a maioria absoluta de votos ou, quando inexistente alguém nessa situação, se ele obteve a maioria, mas três últimas assembleias gerais (Res. n. 401, item IV). O objeto do preceito regulamentar era a alienação do poder de controle das companhias abertas, a que se deveria proceder, por força do art. 254 da LSA, mediante oferta pública de aquisição de ações, com prévia autorização da CVM, para assegurar tratamento paritário aos demais acionistas. Em 1997, com a revogação do referido dispositivo da lei acionária, é evidente que a norma infralegal, que o disciplina, perde eficácia. O critério, contudo, continua pertinente: quem não dispõe de ações correspondentes a mais da metade do capital com direito a voto deve ser considerado controlador se, nas últimas três assembleias, fez a maioria nas deliberações sociais."

153 A Comissão de Valores Mobiliários (CVM), por meio da Instrução no 323, de 19.1.2000, também apresenta detalhada lista exemplificativa de condutas que configuram exercício abusivo do poder de controle: "Art. $1^{\circ}$ - São modalidades de exercício abusivo do poder de controle de companhia aberta, sem prejuízo de outras previsões legais ou regulamentares, ou de outras condutas assim entendidas pela CVM: I - a denegação, sob qualquer forma, do direito de voto atribuído, com exclusividade, por lei, pelo estatuto ou por edital de privatização, aos titulares de ações preferenciais ou aos acionistas minoritários, por parte de acionista controlador que detenha ações da mesma espécie e classe das votantes; II - a realização de qualquer ato de reestruturação societária, no interesse exclusivo do acionista controlador; III - a alienação de bens do ativo, a constituição de ônus reais, a prestação de garantias, bem como a cessação, a transferência ou a alienação, total ou parcial, de atividades empresariais, lucrativas ou potencialmente lucrativas, no interesse preponderante do acionista controlador; IV - a obtenção de recursos através de endividamento ou por meio de aumento de capital, com o posterior empréstimo desses recursos, no todo ou em parte, para sociedades sem qualquer vínculo societário com a companhia, ou que sejam coligadas ao acionista controlador ou por ele controladas, direta ou indiretamente, em condições de juros ou prazos desfavoráveis relativamente às prevalecentes no mercado, ou em condições incompatíveis com a rentabilidade média dos ativos da companhia; V - a celebração de contratos de prestação de serviços, inclusive de gerência e de assistência 
ao interesse nacional, ou levá-la a favorecer outra sociedade; b) promover a liquidação de companhia próspera; praticar atos societários que visem a causar prejuízo a acionistas minoritários; d) eleger administrador ou fiscal que sabe inapto, moral ou tecnicamente; e) induzir, ou tentar induzir, administrador ou fiscal a praticar ato ilegal, ou, descumprindo seus deveres; f) contratar com a companhia em condições de favorecimento ou não equitativas; g) aprovar ou fazer aprovar contas irregulares de administradores, etc.

A prática de atos que configurem abuso de poder de controle gera o dever de indenizar (Lei nº 6.404/76, art. 17), pois como decidiu o Colegiado da CVM,

quando o controlador, em detrimento de tais interesses, legalmente impostos, intencionalmente privilegia outros interesses, ou quando deliberadamente se omite em usar o seu poder no interesse da empresa e da comunidade, resta caracterizado o abuso do poder de controle, pelo que po-

técnica, com sociedades coligadas ao acionista controlador ou por ele controladas, em condições desvantajosas ou incompatíveis às de mercado; VI - a utilização gratuita, ou em condições privilegiadas, de forma direta ou indireta, pelo acionista controlador ou por pessoa por ele autorizada, de quaisquer recursos, serviços ou bens de propriedade da companhia ou de sociedades por ela controladas, direta ou indiretamente; VII - a utilização de sociedades coligadas ao acionista controlador ou por ele controladas, direta ou indiretamente, como intermediárias na compra e venda de produtos ou serviços prestados junto aos fornecedores e clientes da companhia, em condições desvantajosas ou incompatíveis às de mercado; VIII - a promoção de diluição injustificada dos acionistas não controladores, por meio de aumento de capital em proporções quantitativamente desarrazoadas, inclusive mediante a incorporação, sob qualquer modalidade, de sociedades coligadas ao acionista controlador ou por ele controladas, ou da fixação do preço de emissão das ações em valores substancialmente elevados em relação à cotação de bolsa ou de mercado de balcão organizado; IX - a promoção de alteração do estatuto da companhia, para a inclusão do valor econômico como critério de determinação do valor de reembolso das ações dos acionistas dissidentes de deliberação da assembleia geral, e a adoção, nos doze meses posteriores à dita alteração estatutária, de decisão assemblear que enseje o direito de retirada, sendo o valor do reembolso menor ao que teriam direito os acionistas dissidentes se considerado o critério anterior; X - a obstaculização, por qualquer modo, direta ou indiretamente, à realização da assembleia geral convocada por iniciativa do conselho físcal ou de acionistas não controladores; XI - a promoção de grupamento de ações que resulte em eliminação de acionistas, sem que lhes seja assegurada, pelo acionista controlador, a faculdade de permanecerem integrando o quadro acionário com, pelo menos, uma unidade nova de capital, caso esses acionistas tenham manifestado tal intenção no prazo estabelecido na assembleia geral que deliberou o grupamento; XII - a instituição de plano de opção de compra de ações, para administradores ou empregados da companhia, inclusive com a utilização de ações adquiridas para manutenção em tesouraria, deixando a exclusivo critério dos participantes do plano o momento do exercício da opção e sua venda, sem o efetivo comprometimento com a obtenção de resultados, em detrimento da companhia e dos acionistas minoritários; XIII - a compra ou a venda de valores mobiliários de emissão da própria companhia, de forma a beneficiar um único acionista ou grupo de acionistas; XIV - a compra ou a venda de valores mobiliários em mercado, ou privadamente, pelo acionista controlador ou pessoas a ele ligadas, direta ou indiretamente, sob qualquer forma, com vistas à promoção, pelo acionista controlador, do cancelamento do registro de companhia aberta; XV - a aprovação, por parte do acionista controlador, da constituição de reserva de lucros que não atenda aos pressupostos para essa constituição, assim como a retenção de lucros sem que haja um orçamento que, circunstanciadamente, justifique essa retenção.” 
de ele, nos termos do art. 117, caput, da Lei das S/A, ser responsabiliza$\mathrm{do}^{154}$.

\section{A administração das sociedades empresárias}

PONTES DE MIRANDA, em seu Tratado de Direito Privado (1974, t. 3, p. 231), destaca que, nos atos da vida, cada um os pratica individualmente, ativa ou passivamente, de modo que, em regra, não há representação, pois quem age é a própria pessoa, não um seu representante ou procurador. Daí que, se se tratar de pessoa jurídica, quem pratica o ato é seu presentante, por meio de seu órgão.

No mesmo sentido, MENDONÇA (1914, v. 3, p. 87) explica que, diversamente do que ocorre na representação, em que o representante substitui o representado, na administração das pessoas jurídicas, os administradores manifestam exteriormente a vontade coletiva, ou seja, a vontade da própria pessoa jurídica: os administradores não manifestam sua vontade pessoal em substituição ou representando a sociedade. Ao contrário, é a própria pessoa jurídica que se manifesta por intermédio de seu órgão social (CARVALHO, 2006, p. 42).

O administrador, assim, é o órgão da pessoa jurídica a quem se atribui a responsabilidade por gerir o negócio e dirigir a empresa, tanto internamente (contratando, promovendo e demitindo funcionários, organizando a execução dos serviços, pagando salários, impostos e fornecedores, etc.) quanto externamente, em relação a terceiros, função esta que o administrador exerce enquanto órgão da sociedade, não como procurador ou representante, pois, repita-se, o administrador presenta a sociedade (PONTES DE MIRANDA, 1972, t. 50, p. 385).

\subsection{A administração da sociedade limitada}

A administração da sociedade limitada está regulada nos arts. 1.060 a 1.065 do Código Civil, incidindo supletivamente, na hipótese de omissão, o disposto nos arts. 1.010 a 1.021 do Código Civil, que tratam da administração da sociedade simples. Se o contrato

\footnotetext{
${ }^{154}$ Colegiado da CVM, Proc. CVM RJ 2004/5494, Reg. Col. N. 4483/2004, Rel. Diretor Wladimir Castelo Branco Castro, j. 16.12.2004 (LAZZARESCHI, 2010. p. 185).
} 
social, contudo - valendo-se da faculdade de que trata o parágrafo único do art. 1.053 do Código Civil -, dispuser que na hipótese de omissão aplicar-se-ão as normas relativas às sociedades por ações, neste caso, a administração da limitada estará regulada pelo disposto nos arts. 1.060 a 1.065 do Código Civil e, supletivamente, pelos arts. 138 a 160 da Lei $\mathrm{n}^{\circ}$ $6.404 / 76$.

O primeiro artigo que trata da administração da limitada no Código Civil é o 1.060, segundo o qual "a sociedade limitada é administrada por uma ou mais pessoas designadas no contrato social ou em ato separado", sendo que no caso de a administração ser atribuída a todos os sócios, o ingresso de um novo membro no quadro social não o torna automaticamente administrador da sociedade (parágrafo único).

Já o art. 1.061 estabelece, para a hipótese de o contrato social admitir a designação de administrador não sócio, qual o quórum necessário para a escolha desse administrador não sócio, a saber, unanimidade se o capital social não estiver integralizado e dois terços, no mínimo, após a integralização. A exigência da unanimidade decorre do fato de que, nos termos do art. 1.052 do Código Civil, todos os sócios respondem solidariamente pela integralização do capital social (COELHO, 2003, p. 65).

Há controvérsias, porém, na interpretação do referido art. 1.061 do Código Civil em relação ao quórum para a nomeação de administrador não sócio se o capital social já estiver integralizado. Assim é que, para CARVALHOSA (2003, p. 112), o quórum fixado na lei para a nomeação de administrador não sócio, após a integralização do capital social, é de dois terços dos quotistas, e não do capital social.

Diverso, contudo, é o entendimento de VERÇOSA (2006 ${ }^{\mathrm{b}}$, v. 2, p. 445) e COELHO (2003, p. 65), para quem, após a integralização do capital social, o quórum para a nomeação de administrador não sócio não é de dois terços dos quotistas, mas de dois terços do capital social, uma vez que, de acordo com o disposto no art. 1.076 do Código Civil, todos os quóruns estabelecidos para a sociedade limitada são fixados em função do capital social, e não da quantidade de sócios, devendo a mesma regra ser aplicável para a eleição de administrador não sócio após a integralização do capital social. 
Os administradores da limitada, assim, podem ser nomeados no próprio contrato social ou em ato em separado, e podem ou não ser sócios. Quatro, portanto, são as opções: (a) administrador sócio nomeado no contrato social; (b) administrador não sócio nomeado no contrato social; (c) administrador sócio nomeado em ato separado; e (d) administrador não sócio nomeado em ato separado. Dependendo da opção dos quotistas, os quóruns para nomeação e destituição do administrador serão diferentes.

Acrescente-se ainda que o art. 1.065 do Código Civil impõe aos administradores da sociedade limitada a obrigação de prestar contas anualmente mediante a elaboração, após o término do exercício social, de inventário, de balanço patrimonial e de balanço de resultado econômico.

Se a limitada reger-se supletivamente pelas normas que regulam a sociedade simples (art. 1.053 do Código Civil), neste caso, aplicar-se-ão, nas hipóteses de omissão, e desde que não haja contradição, o disposto nos arts. 1.010 a 1.021 do Código Civil, que, em suma, (a) disciplinam as deliberações dos sócios, (b) impõem ao administrador o dever de diligência, (c) regulam os impedimentos ao exercício do cargo de administrador, (d) estabelecem as formalidades para a investidura e o desligamento do cargo, (e) disciplinam os limites dos poderes dos administradores, e (f) preveem as responsabilidades dos administradores.

Entretanto, se no contrato social da limitada os sócios dispuserem que, no caso de omissão, serão aplicados os dispositivos da Lei das Sociedades por Ações, nesta hipótese a regência supletiva será do disposto nos arts. 138 a 160 da Lei nº 6.404/76, de modo que, como esclarece CARVALHO (2006, p. 35), poderão ser invocadas as normas específicas relativas ao Conselho de Administração e à diretoria, bem como as regras comuns referentes aos administradores (diretores e conselheiros), tais como impedimentos, investidura, remuneração, deveres fiduciários de diligência, lealdade e de prestar informações, conflitos de interesses, etc.

É importante destacar, por oportuno, que muitas das normas da Lei das Sociedades por Ações que tratam da administração da companhia - e que podem ser aplicadas supletivamente às sociedades limitadas - são similares às normas do Código 
Civil que regulam a administração da sociedade simples - e que também podem ser aplicadas supletivamente às sociedades limitadas.

Este é o caso, por exemplo, das normas da Lei das Sociedades por Ações que tratam do dever de diligência (art. 153) e dos impedimentos ao exercício do cargo de administrador (art. 147), as quais são muito similares às normas que regulam essas matérias quanto à administração da sociedade simples, a saber, o art. 1.011 do Código Civil. Deste modo, quer a sociedade limitada seja regida supletivamente pelas normas da sociedade por ações, quer incidam supletivamente as regras da sociedade simples, os deveres de diligência e os impedimentos ao exercício do cargo de administrador serão os mesmos.

O que realmente há de diferente na administração da limitada e da sociedade por ações é o conselho de administração, cuja existência é obrigatória em algumas companhias e supletiva em outras, mas que não está prevista nas normas que regem a sociedade limitada.

Isto não obstante, é necessário destacar que embora as normas do Código Civil não estabeleçam a existência do conselho de administração em sociedades limitadas, não há qualquer proibição à instalação desse órgão. Não poderá ter o conselho, porém, competência para praticar atos que a lei atribui exclusivamente aos sócios da limitada, tal como, exemplificativamente, a eleição de administradores, pois tendo a competência sido atribuída pela lei, não podem os sócios delegá-la a outro órgão social.

Deste modo, segundo RETTO (2007, p. 122), como o art. 1.071 do Código Civil estabelece quais matérias devem ser deliberadas exclusivamente pelos sócios e, embora os quotistas possam criar o conselho de administração para a sociedade limitada, não podem os sócios atribuir a este órgão competência para deliberar sobre matérias que a lei determinou fossem decididas exclusivamente pelos próprios sócios.

Finalmente, e como já se disse, quer a sociedade limitada seja regida supletivamente pelas normas da Lei $\mathrm{n}^{\circ}$ 6.404/76, quer incidam supletivamente as regras da sociedade simples, quatro são as possibilidades de escolha do administrador (sócio ou não) e de sua nomeação (no contrato social ou em ato separado), sendo importante destacar que 
os quóruns para nomeação e destituição dos administradores variam em função da escolha feita pelos quotistas, como destaca CARVALHOSA (2003, p. 111):

(a) administrador sócio nomeado no próprio contrato social: o quórum para nomeação do administrador no momento da constituição da sociedade é a unanimidade, mas para a eleição de novo administrador o quórum é de três quartos do capital social, nos termos do art. 1.076, inc. I, combinado com o art. 1.071, inc. V, do Código Civil. Para sua destituição, o quórum de deliberação é de dois terços do capital social, como dispõe o art. $1.063, \S 1^{\circ}$, do Código Civil, salvo se os sócios estabelecerem quórum diverso no próprio contrato social;

(b) administrador sócio nomeado em ato separado: nos termos do art. 1.076, inc. II, combinado com o art. 1.071, inc. II e III, do Código Civil, tanto o quórum para nomeação quanto o para a destituição do administrador é de mais metade do capital social;

(c) administrador não sócio nomeado no próprio contrato social: porque todos os sócios respondem solidariamente pela integralização do capital social (art. 1.052, Código Civil), enquanto o capital não estiver totalmente integralizado, a eleição do administrador exige a aprovação da unanimidade dos sócios (art. 1.061, Código Civil); entretanto, após a integralização, o quórum para a eleição de administrador não sócio é reduzida para dois terços (dos quotistas para CARVALHOSA (2003, p. 112) ou do capital social para VERÇOSA (2006 ${ }^{\text {, }}$ p. 445) e COELHO (2003, p. 65)). Já para a destituição do administrador, o quórum é de mais da metade do capital social (art. 1.076, inc. II, combinado com o art. 1.071, inc. III, do Código Civil); e

(d) administrador não sócio nomeado em ato separado: o quórum para nomeação do administrador não sócio designado em ato separado é o mesmo do administrador não sócio nomeado no próprio contrato social, a saber: unanimidade dos quotistas se o capital social não estiver totalmente integralizado (art. 1.061 do Código Civil), ou por deliberação de dois terços (dos quotistas ou do capital social), caso este já se encontre totalmente integralizado (art. 1.061). Para a destituição do administrador não sócio nomeado em ato separado, o quórum é de mais da metade do capital social, segundo expressamente dispõem o art. 1.076, inc. II, e o art. 1.071, inc. III, ambos do Código Civil. 


\subsection{A administração da sociedade por ações}

Nas sociedades limitadas, como se viu, a administração é exercida por um único órgão, a diretoria, não sendo vedada, contudo, a constituição de conselho de administração. Diversa, porém, é a administração da sociedade por ações, pois em alguns casos é obrigatória a existência do conselho.

Com efeito, segundo dispõe o art. 138 da Lei das Sociedades por Ações, "a administração da companhia competirá, conforme dispuser o estatuto, ao conselho de administração e à diretoria, ou somente à diretoria”, acrescentando o parágrafo segundo que "as companhias abertas e as de capital autorizado terão obrigatoriamente conselho de administração.” Por fim, também é imperativa a constituição de conselho de administração nas sociedades de economia mista (art. 239 da Lei das S/A), que não está sujeita à falência e não poderá se valer da recuperação judicial (art. $2^{\circ}$, LREF).

Desse modo, nas companhias abertas, naquelas em que houver capital autorizado e nas sociedades de economia mista, a administração será exercida obrigatoriamente por dois órgãos distintos: a diretoria e o conselho de administração. Nas demais companhias, a existência do conselho de administração é facultativa, de modo que a administração poderá será exercida (a) apenas pela diretoria ou (b) pelo conselho de administração em conjunto com a diretoria.

Embora nas companhias fechadas não seja obrigatória a existência de conselho de administração, PARENTE (2005, p. 7) destaca que o Código de Melhores Práticas de Governança Corporativa, editado pelo Instituto Brasileiro de Governança Corporativa, recomenda, em seu item 2.01, a criação deste órgão, quer o capital seja aberto quer seja fechado.

Nas companhias em que a administração é composta por dois órgãos distintos, à diretoria compete a presentação da sociedade, sendo o conselho órgão de deliberação colegiada (art. 138, $\S 2^{\circ}$, Lei $n^{\circ}$ 6.404/76), acrescentando o art. 139 da mesma lei que "as atribuições e poderes conferidos por lei aos órgãos de administração não podem ser outorgados a outro órgão, criado por lei ou pelo estatuto.” Em consequência, porque a lei atribui ao conselho de administração apenas poder de deliberar, o estatuto não poderá 
outorgar a este órgão colegiado poder para presentar a companhia, pois, repita-se, a lei atribuiu à diretoria, com exclusividade, competência para a presentação da sociedade.

Para BRANCO (2007, p. 35), ao instituir dois órgãos administrativos, a Lei das Sociedades por Ações limitou a autonomia da diretoria, pois subordinou seus poderes às diretrizes gerais que são determinadas pelo conselho de administração. Entretanto, prossegue o mesmo autor, a existência do conselho não altera as responsabilidades, as funções e os encargos dos diretores, que passam a ser eleitos pelos conselheiros, e não pelos acionistas.

Daí que, como destaca PARENTE (2005, p. 5), cada um dos órgãos previstos na Lei das Sociedades por Ações tem competência própria e função específica: à assembleia geral compete apurar qual a vontade social; ao conselho de administração, se existente, compete fixar as diretrizes gerais da companhia; à diretoria compete a execução da vontade social; e ao conselho fiscal (se existente) compete a fiscalização dos negócios sociais.

Os conselheiros, por outro lado, são eleitos pela assembleia geral e por ela destituíveis a qualquer momento, podendo os acionistas, na eleição dos conselheiros, valerem-se do voto múltiplo e do voto em separado (arts. 140 e 141 da Lei no 6.404/76).

Da mesma forma, os membros da diretoria, que será composta obrigatoriamente por no mínimo 2 (dois) diretores, são eleitos e destituíveis a qualquer tempo. Se a companhia contar conselho de administração, a esse órgão compete a eleição dos diretores. Entretanto, nas sociedades por ações em que a administração é exercida apenas pela diretoria, seus membros são eleitos pelos acionistas reunidos em assembleia geral.

Acrescente-se, por fim, que tanto aos conselheiros como aos diretores (ou seja, a todos administradores das sociedades por ações) são impostos os deveres fiduciários de diligência (art. 153), de lealdade (art. 155) e de obediência (art. 158) à lei e ao estatuto social. 


\section{Retomando o conceito de devedor na LREF}

A interpretação literal da LREF, como se disse, conduz à conclusão de que devedor, sujeito a afastamento e substituição pelo gestor judicial, são apenas o empresário individual, a sociedade empresária, os sócios de responsabilidade ilimitada, e também a empresa individual de responsabilidade limitada.

Isso não obstante, há divergência doutrinária quanto à interpretação do termo devedor, porquanto há autores que sustentam que o termo refere-se à própria sociedade; outros defendem que devedor, para efeito de afastamento e substituição pelo gestor judicial, devem ser todos os seus sócios (ou acionistas); outros ainda aduzem que devedor é o acionista (ou sócio) controlador; e há quem argumente que devedor são os administradores.

Pois bem, feito o exame, ainda que superficial, de quem são os administradores e o controlador (ou grupo de controle) da sociedade empresária limitada e da sociedade por ações (únicas, repita-se, objeto deste estudo), faz-se necessário analisar qual parece ser a melhor interpretação do termo devedor empregado nos arts. 64 e 65 da LREF, de regra mantido na condução da atividade empresarial, mas excepcionalmente afastado pelo juiz e substituído pelo gestor judicial eleito pelos credores reunidos em assembleia geral.

De início, porém, é necessário lembrar que, ao contrário do que sustentam FONSECA (2009, p. 448), CAMPINHO (2008, p. 153) e VERÇOSA (2006a , p. 30), não parecer ser a melhor interpretação a que considera devedor, para efeito de afastamento e substituição pelo gestor judicial, apenas o empresário individual e, excepcionalmente, a sociedade empresária devedora: se a conduta que implica o afastamento for praticada pelos sócios ou acionistas da sociedade empresária, não se justifica a manutenção desses sócios e/ou da sociedade empresária devedora, pois embora não conduzam diretamente a atividade empresarial, eles é que definem, com o poder que exercem, os rumos e as estratégias empresariais. Em consequência, a nomeação de gestor judicial não pode se restringir às hipóteses de substituição do empresário individual.

Por outro lado, repita-se, todas as condutas descritas nos incisos I a VI do art. 64 da LREF, cuja verificação tem como consequência o afastamento do administrador e/ou 
do devedor, são praticadas (ou se referem) exclusivamente por pessoas naturais (não por pessoas jurídicas), que podem estar na posição de administradores (diretores ou conselheiros), quanto na de sócio ou acionista, ou, ainda, cumulativamente nas duas posições.

Assim é que, por exemplo, o art. 64, inc. IV, alínea “c”, da LREF, estabelece o afastamento do administrador e do devedor na hipótese da prática de ato que importe na descapitalização injustificada da empresa ou que se caracterize como operação prejudicial ao seu funcionamento. Ora, configurando-se como "tipo" aberto, as condutas que nele se subsumem podem ser praticadas tanto pelo administrador da sociedade empresária, enquanto órgão que a presenta (e.g. contratação de negócios sem a observância do dever fiduciário de diligência), quanto pela pessoa natural que integra o órgão de administração, mas agindo em seus negócios pessoais (e.g. utilizar-se de sua posição para extrair benefícios privados em detrimento do devedor, contratando em nome pessoal negócio que deveria ser realizado pela sociedade) e até mesmo por um seu sócio ou acionista (e.g. aprovação em assembleia geral da prática de ato societário que propositalmente diminua a liquidez do devedor).

Daí decorre que o exame das causas de afastamento dos administradores e do devedor não permite aferir qual o sentido atribuído pelos arts. 64 e 65 da LREF ao termo devedor: os atos que se subsumem nas hipóteses legais, embora refiram-se apenas a pessoas naturais, dizem respeito tanto aos sócios quanto aos administradores e até mesmo à própria sociedade empresária, presentada por seus órgãos de administração.

Ademais, e como já se viu, a LREF, seguindo a tradição do Direito Positivo brasileiro, dispõe que a apresentação do pedido de recuperação judicial, a ordem de processamento e a sua homologação não importam no afastamento do devedor ou de seus administradores, que são mantidos na condução da empresa, como taxativamente prescreve o caput do art. 64: "Durante o procedimento de recuperação judicial, o devedor ou seus administradores, serão mantidos na condução da atividade empresarial..."

Ora, valendo-se do brocardo ubi lex voluit dixit, ubi noluit tacuit, que em tradução livre vaticina "onde a lei quis, disse; onde não quis, silenciou", conclui-se que ao se referir, expressamente, ao devedor e aos administradores, a LREF deixou claro que 
esses termos, no referido art. 64, têm sentidos diversos e inconfundíveis, de onde decorre que "devedor" não se confunde com "administrador".

Exatamente porque esses termos têm sentidos distintos, a própria LREF, no parágrafo único do art. 64 e no caput do art. 65, prescreve consequências diversas para as hipóteses de afastamento do administrador (que será substituído por outro eleito na forma prescrita no contrato ou no estatuto social, quer se trate de limitada ou de sociedade por ações, sempre obedecendo-se o disposto, respectivamente, no Código Civil e na Lei das Sociedades por Ações) ou do próprio devedor (cujas atividades serão exercidas pelo gestor judicial eleito pelos credores em assembleia geral).

Bem por isso, o termo devedor, para efeito de afastamento e substituição pelo gestor judicial, não significa administrador (diretor ou conselheiro) da sociedade empresária (limitada ou por ações) em recuperação judicial.

Assim, não se limitando ao empresário individual, e não se referindo aos administradores, resta examinar se devedor é a própria sociedade empresária que se vale da recuperação judicial, ou se são seus sócios ou acionistas, controladores ou não.

MUNHOZ (2007, p. 307), como se disse, esclarece que a interpretação literal da LREF leva à conclusão que, em se tratando de sociedade de responsabilidade limitada, o termo devedor refere-se à própria sociedade, não a seus sócios ou acionistas. Entretanto, como, de fato, quem conduz a empresa são os sócios (ou acionistas) controladores, eles é que devem ser alijados, para que não se prejudiquem os sócios minoritários.

O exercício dos poderes dos sócios, controladores ou não, manifesta-se primordialmente nas reuniões e assembleias gerais, ocasiões em que, por meio do voto, os acionistas deliberam o modo pelo qual a empresa será conduzida, tanto que a aferição de quem é o controlador de determinada sociedade se faz através da apuração da prevalência nas deliberações, elegendo a maioria dos administradores e definindo as atividades sociais e o funcionamento dos órgãos da companhia.

Não se ignora que o poder dos sócios e acionistas, em especial do controlador, também se manifesta, e com muita frequência, fora das reuniões e assembleias, pois, no 
mais das vezes, os administradores, ou são os próprios sócios, ou não passam de seus longa manus, a quem obedecem fielmente, ainda que impondo sacrifícios à própria sociedade que dirigem, e em favor de quem lhes são impostos os deveres fiduciários de lealdade, diligência e obediência à lei e ao contrato (ou estatuto) social. Isso não obstante, a atuação dos sócios se dá, fundamentalmente, nas reuniões e assembleias.

Exatamente por essa razão, durante o processo legislativo que resultou na aprovação da LREF, o Projeto de Lei n $\mathrm{n}^{\circ}$ 4.376-E, que se propunha a regular "a recuperação judicial, a extrajudicial e a falência de devedores pessoas físicas e jurídicas que exerçam atividade econômica regida pelas leis comerciais", expressamente contemplava, em seu art. 59, como regra geral, a manutenção dos administradores e do sócio controlador na condução da atividade empresarial. Isso não obstante, se verificada a prática de determinadas condutas descritas nos incisos do mencionado dispositivo legal, o parágrafo $3^{\circ}$ previa a possibilidade de ambos virem a ser afastados, na qual hipótese, se se tratassem dos administradores, eles seriam destituídos de seus cargos, enquanto o afastamento do sócio controlador se implementaria por meio da suspensão de seu direito de voto ${ }^{155}$.

\footnotetext{
155 Para a perfeita compreensão da previsão de afastamento do sócio controlador, transcreve-se a seguir a íntegra do art. 59 do Projeto de Lei no 4.376-E, publicado no Diário da Câmara do Deputados de 16.10.2003: "Art. 59. Durante o procedimento de recuperação judicial, sob o compromisso de apresentar constas demonstrativas mensais, o sócio controlador e os administradores serão mantidos na condução da atividade empresarial, sob fiscalização do Comitê, se for o caso, ou do administrador judicial, salvo quanto: I - houver sido condenado mediante sentença penal transitada em julgado, por crime cometido em outra recuperação judicial ou falência anteriores ou por qualquer crime contra o patrimônio, contra a economia popular ou contra a ordem econômica previstos na legislação vigente; II - houver indícios veementes de ter cometido crime previsto nesta Lei; III - existir prova de ter agido com dolo, simulação ou fraude contra os interesses de seus credores; IV - ficar demonstrado que praticou uma das seguintes condutas: a) efetuar gastos pessoais manifestamente excessivos ao seu cabedal social; b) efetuar despesas do negócio ou da empresa injustificáveis por sua natureza ou vulto, em relação ao capital, ou gênero do negócio, ao movimento das operações e a outras circunstâncias análogas; c) ter descapitalizado injustificadamente a empresa ou realizado operações prejudiciais ao seu funcionamento regular; d) ter simulado ou omitido créditos ao apresentar a relação de que trata o art. 51, III, sem relevante razão de direito ou amparo de decisão judicial; V - retardar ou recusar-se ao cumprimento do plano de recuperação judicial aprovado pelo juiz; VI - negar-se, durante o processamento da recuperação judicial, a prestar informações solicitadas pelo administrador judicial ou pelos demais membros do Comitê, com o objetivo de estes acompanharem e avaliarem a correta execução do plano de recuperação judicial. $\S 1^{\circ}$ - Não poderá o devedor alienar ou onerar bens e direitos de seu ativo permanente, salvo evidente utilidade reconhecida pelo juiz, depois de ouvidos o Comitê e o Ministério Público, com exceção daqueles previamente relacionados no plano de recuperação judicial aprovado. $\S 2^{\circ}-$ Os atos de endividamento praticados pelo devedor durante o procedimento de recuperação judicial, bem como as despesas com fornecedores de bens ou serviços necessários à continuação das atividades da empresa, contraídos mediante autorização judicial, após a manifestação do Comitê, quando for o caso, serão considerados extraconcursais, em caso de convolação em falência. $\S 3^{\circ}-\mathrm{O}$ afastamento do sócio controlador ocorrerá por meio de suspensão do seu direito de voto, ao passo que o afastamento dos administradores será efetivado por meio da destituição de seus cargos."
} 
O Projeto em discussão à época, assim, não contemplava o gestor judicial como órgão da recuperação judicial, mas apenas dispunha que o afastamento dos administradores se daria pela destituição de seus cargos e o do sócio controlador pela suspensão de seu direito de voto. Em consequência, (a) destituídos os administradores, novos deveriam ser eleitos pelos sócios ou acionistas, na forma ajustada no contrato ou estatuto social. Entretanto, (b) o afastamento do sócio controlador pela suspensão de seu direito de voto teria como efeito conduzir os sócios minoritários à posição de controladores "de fato" da sociedade empresária em recuperação judicial, uma vez que seus votos é que prevaleceriam nas assembleias, e poderiam eles, se quisessem, eleger a maioria dos administradores, definir as atividades sociais e o funcionamento dos órgãos da companhia.

O Projeto de Lei $n^{\circ}$ 4.376-E, contudo, sofreu muitas alterações no curso do processo legislativo, tendo a expressão "sócio controlador" sido substituída pelo termo "devedor", bem como foi instituído o gestor judicial como órgão da recuperação judicial, eleito pelos credores em assembleia geral, a quem se atribuiu a função de administrar o "devedor" no caso de seu afastamento ${ }^{156}$.

Tendo sido expressamente substituída, durante o processo legislativo que deu origem à LREF, a expressão "sócio controlador" por "devedor", e estabelecendo a norma legal consequência absolutamente diversa da que constava do Projeto de Lei $\mathrm{n}^{\circ}$ 4.376-E para a hipótese de afastamento, parece inequívoco que o termo devedor não foi empregado como sinônimo, não se equipara, e nem se refere ao controlador da sociedade empresária.

Acrescente-se, ainda, que embora impressione o argumento de que o afastamento de todos os sócios ou mesmo da pessoa jurídica poderá prejudicar os sócios não controladores que, no mais das vezes, estão alijados do processo de condução da empresa e não praticam quaisquer atos podem dar causa ao afastamento de que trata o art.

\footnotetext{
${ }^{156}$ Expondo, também em nota de rodapé, como se deu a supressão do "sócio controlador" no projeto de lei de recuperação judicial, CEREZETTI (2012, p. 405) destaca que "tendo sido o projeto da Câmara dos Deputados enviado ao Senado, a referência ao acionista controlador deixou de ser feita, passando-se a usar o termo 'devedor', nos termos da Emenda 1 - CAE (Substitutivo) do Senado [...] Ressalte-se que os pareceres 534 e 535, de 2004, das Comissões de Assuntos Econômicos e de Constituição, Justiça e Cidadania respectivamente, que discutiram o texto vindo da Câmara dos Deputados e recomendaram a adoção do Substitutivo da Comissão de Assuntos Econômicos, de relatoria do Senador Ramez Tebet, não discuritam o mérito da substituição da expressão 'acionista controlador' por 'devedor'.”
} 
65 da LREF, não parece ser a melhor interpretação a que atribui ao termo devedor o significado de controlador.

Com efeito, como destaca VERÇOSA (2006 ${ }^{\mathrm{a}}$, p. 33), se devedor, para efeito de afastamento e substituição pelo gestor judicial, fosse o controlador, e se esse último fosse uma pessoa jurídica, a interpretação literal da lei conduziria à conclusão de que também deveriam ser alijados os administradores do sócio controlador, pois o caput do art. 64 dispõe que, em regra, são mantidos, e poderão vir a ser afastados, o "devedor ou seus administradores", o que significaria, de acordo com esta interpretação, "o sócio controlador ou seus administradores".

E esse mesmo raciocínio não se aplica apenas aos controladores, mas também para o caso de afastamento da totalidade dos sócios ou acionistas, pois serão eles substituídos pelo gestor judicial, que passará a integrar a estrutura societária já existente, exercendo todos os direitos políticos dos "devedores" afastados.

Ocorre que, interpretar-se o termo devedor como sócio controlador (ou como os sócios ou acionistas da sociedade empresária em recuperação judicial) pode gerar situações insolúveis. Assim é que, por exemplo, se o acionista controlador de determinada sociedade por ações que ajuizou pedido de recuperação judicial é afastado e substituído pelo gestor judicial, este órgão da recuperação passará a integrar a estrutura societária préexistente. Neste caso, é possível que o gestor judicial, substituindo o acionista, convoque assembleia geral, destitua os administradores e eleja novos, obedecendo o disposto no estatuto social. Ocorre que, como se verá, o gestor judicial não substitui o devedor nos atos referentes ao próprio processo de recuperação judicial, tais como o exame, discussão e aceitação de eventuais alterações ao plano de recuperação sugeridas pelos credores. Neste exemplo, tendo os administradores da sociedade empresária sido destituídos pelo gestor judicial, e seus sucessores sido eleitos em assembleia geral que não contou com o voto do acionista afastado (o devedor), não há quem represente a sociedade empresária devedora no processo de recuperação judicial.

Ademais, se se admitir que devedor é o controlador, a questão que surgirá é se o gestor estará ou não vinculado ao contrato plurilateral de sociedade e a eventuais pactos parassociais e, em consequência, se ele deve ou não respeitar eventuais direitos concedidos 
contratualmente a outros acionistas (como, a título exemplificativo, o poder de veto). Isto porque, como o sócio ou acionista é parte do contrato plurilateral, e pode ter firmado pactos parassociais, se devedor for interpretado como controlador, seu afastamento importará sua substituição (inclusive nos pactos sociais e parassociais) pelo gestor judicial, que estará obrigado a respeitá-los. Entretanto, se devedor for a pessoa jurídica, não os controladores, o gestor judicial não integrará qualquer pacto social ou parassocial, pois administrará a empresa do devedor de fora da estrutura societária. Esta última interpretação do termo devedor (como pessoa jurídica, não como controlador) parece ser a mais consentânea com o disposto nos arts. 64 e 65 da LREF.

Não se ignora a existência de decisões judiciais determinando o afastamento dos sócios controladores, como ocorreu, por exemplo, na recuperação judicial da VARIG Viação Aérea Rio-Grandense S.A., Rio Sul Linhas Aéreas S.A. e Nordeste Linhas Aéreas S.A., onde o Juiz da $8^{\text {a }}$ Vara Empresarial do Rio de Janeiro ${ }^{157}{ }^{158}$ afastou o acionista controlador, considerado "administrador indireto das empresas recuperandas", de qualquer ingerência, proibindo-o de destituir os conselheiros e diretores. Entretanto, pelas razões acima expostas, essa não parece ser a melhor interpretação do termo devedor empregado nos arts. 64 e 65 da LREF.

Daí que, com a devida vênia das opiniões em sentido contrário, entende-se que devedor, nos termos e para os fins dos arts. 64 e 65 da LREF, é a própria sociedade empresária que pede recuperação judicial, não seus sócios, controladores ou não, nem seus administradores.

A consequência dessa interpretação da LREF é que se os atos que justificam o afastamento forem praticados pelos administradores, eles é que serão alijados de seus

$157 \mathrm{O}$ afastamento dos controladores e a nomeação do gestor judicial no processo de recuperação judicial da VARIG - Viação Aérea Rio-Grandense S.A., Rio Sul Linhas Aéreas S.A. e Nordeste Linhas Aéreas S.A., que se processou na $8^{\text {a }}$ Vara Empresarial do Riio de Janeiro (processo n ${ }^{\circ}$ 2005.001.072887-7) será examinada com mais detalhes a seguir.

158 Também a título exemplificativo pode ser citada a recuperação judicial de Cinalp Produtos Alimentícios Ltda., em cujo curso os "sócios" foram afastados e foi determinada a eleição de gestor judicial para administrar a empresa, não para exercer o direito de voto, de onde se conclui que afastada foi a pessoa jurídica, não seus sócios, nem seus administradores, pois, nesta última hipótese, não se nomearia gestor judicial, mas novo administrador na forma do contrato social (TJSP, Agravo de Instrumento ${ }^{\circ}$ 0053075-37.2012.8.26.0000, $2^{\mathrm{a}}$ Câmara Reservada de Direito Empresarial, Relator Desembargador Tasso Duarte de Melo, j. 16.10.2012, v.u.). 
cargos e substituídos por novos escolhidos na forma dos atos constitutivos da sociedade empresária devedora; entretanto, se os atos que se subsumem nas hipóteses dos incisos do art. 64 da LREF tiverem sido praticados pelos sócios da sociedade empresária devedora, afastada será a própria sociedade devedora, hipótese na qual os credores elegerão (e o juiz nomeará) o gestor judicial que conduzirá as atividades do devedor de fora da estrutura societária.

Acrescente-se ainda que, tendo em vista o predomínio no Brasil do controle concentrado de empresas onde, no mais das vezes, os administradores são os próprios sócios ou pessoas a ele relacionadas, a prática do ato que se subsume em uma das hipóteses dos incisos do art. 64 da LREF acarretará o afastamento tanto dos administradores quanto da própria pessoa jurídica devedora, caso em que incide o disposto no art. 65 da LREF e os credores devem eleger o gestor judicial para conduzir a empresa, não se aplicando a norma do parágrafo único art. 64, porquanto, afastada a pessoa jurídica, não é possível eleger-se novos administradores na forma ajustada no contrato (ou estatuto) social.

A partir dessa posição, faz-se necessário analisar as causas de afastamento do devedor da condução da empresa, bem como o modo pelo qual se implementa esse alijamento e sua substituição pelo gestor judicial.

\section{A recuperação judicial de VARIG - Viação Aérea Rio-Grandense S.A., Rio Sul Linhas Aéreas S.A. e Nordeste Linhas Aéreas S.A.}

As devedoras VARIG - Viação Aérea Rio-Grandense S.A., Rio Sul Linhas Aéreas S.A. e Nordeste Linhas Aéreas S.A., impetraram recuperação judicial perante a $8^{\text {a }}$ Vara Empresarial do Rio de Janeiro (processo no 2005.001,072887-7), em cujo curso os credores foram convocados para se reunirem em assembleia para deliberar sobre o plano de recuperação.

Alguns dias antes da data designada para realização do conclave, o controle da VARIG foi alienado para Docas Investimentos S.A., negócio esse cujos efeitos foram suspensos pelo Juiz da $8^{\text {a }}$ Vara Empresarial do Rio de Janeiro sob o fundamento de que, na forma do art. 50, III, da LREF, a transferência do controle de sociedade em recuperação judicial depende de aprovação dos credores. 
Ainda antes da assembleia de credores foi apresentado pedido de desistência do processo de recuperação judicial, pedido esse rejeitado por decisão que, em sua parte final, de ofício, e invocando a norma do art. 64 da LREF, afastou o acionista controlador nos seguintes termos:

Trata-se de pedido de desistência de pedido de recuperação judicial, formulado pelas empresas em recuperação, nada obstante firmado por advogado sem poderes para tanto.

Logo após a decisão que suspendeu a eficácia da alienação do controle acionário, por entender ser necessária a manifestação dos credores na forma estabelecida pelo art. 50, III, da Lei 11.101/2005, estranhamente, as empresas em recuperação judicial, patrocinadas pelas controladoras, formulam pedido de desistência da recuperação [...]

Em primeiro lugar, as empresas em recuperação judicial não se confundem com a controladora, que assina a petição sob exame. Não há, portanto, legitimidade que ampare a pretensão, estando evidenciada a sua ilegitimidade pela inobservância do art. $6^{\circ}$ do CPC. [...]

É notório, outrossim, que os administradores das empresas em recuperação, que vêm desempenhando um papel importante para o atingimento do fim esperado, não têm a indispensável liberdade e tranquilidade para gerir a empresa no estado enfermo em que se encontra. Em momento recente, a antiga administração foi destituída pelo controlador, havendo, por óbvio, uma odiosa a perigosa instabilidade nas empresas, considerando, em especial, a proximidade da data da realização da assembleia em que será examinado o plano apresentado pelo devedor, consoante disposição legal.

Agora, restando menos de quatro dias para a dita assembleia, o peticionante, desprovido de legitimidade, requer a desistência da ação de recuperação judicial.

Evidencia-se uma rotina prejudicial à pretensão da empresa que abriga milhares de empregos. A instabilidade gera pânico e, consequentemente, prejudica o bom andamento do processo.

Sem prejuízo da afirmada ilegitimidade, o juízo está convencido que a manutenção da situação poderá representar a frustração do plano apresentado pelos devedores trazendo consequências inimagináveis à coletividade. Dispensável dizer, inclusive, que tal pedido depende de aprovação dos credores em assembleia, conforme dita o art. 52, $\S 4^{\circ}$ da lei especial.

Nesse sentido, porque evidenciada uma instabilidade na condução exemplar da atual direção das empresas em recuperação, desatendendo o princípio inspirador da lei e, ainda, porque a fundamentação do pedido nos conduz à idéia de indevida ingerência do controlador - inclusive maltratando princípios inscritos na lei que regula as sociedades anônimas e, por óbvio que se aplica de forma subsidiária à hipótese em comento -, indispensável um pronto pronunciamento judicial, 'blindando' os responsáveis pela condução e ultimação dos trabalhos relativos à reorganização das empresas. 
Ante o exposto, na forma do art. 64 da Lei $\mathrm{n}^{\circ} 11.101 / 2005$, afasto o acionista controlador, assim entendido como administrador indireto das empresas recuperandas, de qualquer ingerência político-administrativa, impedindo-o, em especial, de destituir qualquer membro do Conselho de Administração, devendo, ainda, manter a atual Diretoria.

Contra essa decisão, as recuperandas e os controladores interpuseram o agravo de instrumento $n^{\circ}$ 29.242/2005 que, dada a urgência, foi apreciado no Plantão Judiciário pelo Desembargador Siro Darlan de Oliveira, que atribuiu efeito suspensivo ao recurso nos seguintes termos:

[...] o acionista controlador deve ser mantido, sendo que o seu afastamento é matéria de interesse dos credores, razão pela qual deverá também ser enfrentado na oportunidade da realização da assembleia convocada, sendo certo que não há previsão legal dentre as hipóteses elencadas no artigo 64 para justificar o afastamento do acionista controlador.

Distribuído o agravo de instrumento para a $4^{\mathrm{a}}$ Câmara Cível do Tribunal de Justiça do Rio de Janeiro, antes de seu julgamento o Ministério Público interpôs agravo regimental, tendo sido proferida pelo Juiz Paulo Maurício Pereira, durante Plantão Noturno, decisão revogando o efeito suspensivo que fora atribuído ao agravo de instrumento pelo Desembargador Siro Darlan de Oliveira.

Antes do julgamento do agravo de instrumento $\mathrm{n}^{\circ} 29.242 / 2005$, foi realizada assembleia de credores, ocasião em que o plano de recuperação foi aprovado, razão pela qual a Quarta Câmara Cível do Tribunal de Justiça do Rio de Janeiro, Relator Desembargador Jair Pontes de Almeida, declarou, por votação unânime, prejudicado o recurso (j. 10.1.2006).

Contra esse acórdão, a FRB-PAR Investimentos S.A. (controladora direta das devedoras) e a Fundação Rubem Berta (controladora da FRB-PAR Investimentos) opuseram embargos de declaração alegando a existência de omissão no acórdão, pois a aprovação do plano de recuperação pelos credores tornou prejudicado o agravo de instrumento apenas quanto à desistência do pedido de recuperação judicial, não quanto à decisão que afastou os controladores. 
Esses embargos de declaração foram julgados pela mesma Quarta Câmara Cível do Tribunal de Justiça do Rio de Janeiro (j. 6.6.2003) que, reconhecendo a existência de omissão, confirmou que o agravo de instrumento estava prejudicado em relação ao pedido de desistência da recuperação judicial e, quanto ao afastamento dos controladores, negou provimento ao recurso:

O pedido de restabelecimento dos plenos direitos dos acionistas controladores das requerentes da recuperação judicial se inicia com críticas ao Juiz da causa, que entenderia também de administração de empresas aéreas, emitindo juízo de valor sobre a capacidade da diretoria executiva da primeira Agravante, sobrepondo-se ao controlador, de quem retira poderes de controle, assegurados por expressa disposição legal.

Apontam, a seguir, equivocada a invocação da regra do artigo 64, da Lei $\mathrm{n}^{\circ} 11.101 / 2005$, que, a seu juízo, se refere ao devedor e seus administradores, não ao acionista controlador, aduzindo necessária a providência apontada pelo artigo 65 , da mesma lei.

Entretanto como acentua, com acerto, a D. Procuradoria da Justiça, em seu bem lançado parecer de fls. 248/250:

‘... a decisão impugnada proferida pelo Juízo de primeiro grau neutralizou o exercício da preponderância do acionista controlador na condução das companhias em recuperação, reconhecendo uma prática rotineira de indevida e prejudicial ingerência à pretensão de reorganização das empresas, gerando perigosa instabilidade e prejudicando o bom andamento do processo.

Saliente-se que o provimento judicial contém fundamentação minuciosa e adequada das razões adotadas pelos Juízes, sendo insustentável a alegação de ausência de fundamentação.

No que diz respeito à formatação de convicção a respeito do exercício abusivo do poder pelo acionista controlador, o Magistrado conta com discricionariedade cognitiva sendo descabido assinalarlhe diretrizes nesse mister.

O artigo 64 da Lei 11.101/2005 autoriza o afastamento dos administradores durante o procedimento de recuperação judicial.

Assim sendo, o ato judicial praticado nos limites da lei, no exercício regular da função jurisdicional, interpretando e aplicando a lei ao caso concreto, não pode ser tachado de ilegal'.

Adota-se integralmente, nos termos regimentais, o parecer, por se demonstrar em perfeita harmonia com o pensar e o sentir desta Câmara, a respeito do tema versado.

O Tribunal de Justiça do Rio de Janeiro, assim, confirmou a decisão da $8^{\text {a }}$ Vara Empresarial do Rio de Janeiro que, invocando o art. 64 da LREF, afastou o acionista controlador das devedoras, "assim entendido como administrador indireto das empresas recuperandas", impedindo-o expressamente de "qualquer ingerência político- 
administrativa, [...] em especial, de destituir qualquer membro do Conselho de Administração, devendo, ainda, manter a atual Diretoria”.

O afastamento do acionista controlador nesse processo de recuperação judicial chama a atenção ao menos por duas relevantes questões relativas à interpretação e incidência das normas dos arts. 64 e 65 da LREF.

A primeira questão, e que será melhor abordada no próximo capítulo desta dissertação, refere-se às hipóteses de afastamento, relacionadas nos incisos do já referido art. 64 da LREF. Isso porque, como se verá, as circunstâncias descritas nos mencionados incisos do art. 64 (que justificam o afastamento dos administradores ou do devedor porque comprometem sua credibilidade) são numerus clausus e, em consequência, (a) não admitem interpretação extensiva, e (b) não é possível o afastamento dos administradores ou do devedor em outras hipóteses não previstas expressamente na norma legal, ainda que os fatos invocados afetem a idoneidade deles.

No caso específico da recuperação judicial da VARIG - Viação Aérea RioGrandense S.A., da Rio Sul Linhas Aéreas S.A. e da Nordeste Linhas Aéreas S.A., a $8^{\text {a }}$ Vara Empresarial do Rio de Janeiro referiu expressamente o art. 64 da LREF mas, sem especificar em qual das cirunstânicas descritas na lei se subsumiam os fatos, de ofício (ou seja, sem pedido de qualquer interessado), afastou os controladores porque eles, no curso do processo de recuperação, substituíram os administradores, o que teria causado "odiosa e perigosa instabilidade nas empresas”, situação essa cuja manutenção “poderá representar a frustração do plano apresentado pelos devedores".

Ocorre que os fatos descritos na decisão judicial (que foi confirmada pela Quarta Câmara Cível do Tribunal de Justiça do Rio de Janeiro) para justificar o afastamento do "devedor" não se subsumem em nenhuma das hipóteses legais: (a) não se trata de condenação penal transitada em julgado (art. 64, inc. I); (b) não há indícios da prática de crime (art. 64, inc. II); (c) não se narrou ato praticado com dolo, simulação ou fraude contra credores (art. 64, inc. III); (d) não se afirmou a contratação de gastos pessoais excessivos (art. 64, inc. IV, “a”); (e) não se referiu a assunção de despesas injustificáveis em relação ao capital ou gênero do negócio (art. 64, inc. IV, “b”); (f) não se descapitalizou a empresa (art. 64, inc. IV, “c”); (g) não se similou nem se omitiu créditos (art. 64, inc. IV, 
“d”); (h) não se negou a prestar informações (art. 64, inc. V); e (i) não se previu o afastamento no plano de recuperação judicial (art. 64, inc. VI).

Daí que o afastamento do devedor ocorreu em virtude de fatos não previstos na norma legal, de onde se conclui que, contrariando o que sustentam os mais importantes (senão todos) os doutrinadores, decidiu-se, no caso em exame, que as hipóteses dos incisos do art. 64 da LREF são meramente exemplificativas, não numerus clausus, o que gera insegurança jurídica: admitir-se essa interpretação importa outorgar ao Judiciário poder para, de ofício, afastar administradores e devedor independentemente da ocorrência ou não de qualquer um dos fatos descritos em lei. Essa, porém, não parece ser a correta interpretação legal.

Por outro lado, a decisão de afastamento do "devedor" nesse processo de recuperação judicial também chama a atenção porque o Judiciário, no caso, interpretou o termo devedor como acionista controlador ("administrador indireto das empresas recuperandas") e, em consequência, impediu-o de "qualquer ingerência políticoadministrativa", notadamente a destituição de "destituir qualquer membro do Conselho de Administração, devendo, ainda, manter a atual Diretoria”.

Como já se demonstrou, contudo, a melhor interpretação do termo “devedor" é a própria sociedade devedora, não seus sócios (controladores ou não) nem seus administradores, de modo que a decisão da $8^{\text {a }}$ Vara Empresarial do Rio de Janeiro, confirmada pela Quarta Câmara Cível do Tribunal de Justiça do Rio de Janeiro, parece não ter sido a mais consentânea à norma legal, como destaca MENEZES (2012, p. 120):

Em que pese a aparente atuação do ex-controlador da Varig com desvio de finalidade em em conflito de interesses, o decreto de seu afastamento não parece corresponder à sanção prevista na Lei n. 11.101/2005 para casos tais, devendo-se aplicar, a esse propósito, o regime de responsabilidade previsto na lei societária [...]

Nada impediria, por outro lado, que acionistas minoritários da Varig ingressassem com demanda de responsabilidade em face do excontrolador por abuso do poder, casos seus desvios de finalidade acabassem por inviabilizar ou atrasar a concessão da recuperação judicial, trazendo graves prejuízos à companhia [...] 
Essas são, assim, especificamente em relação ao afastamento do "devedor", as duas relevantes questões que merecem ser destacadas do processo de recuperação judicial em análise, as quais, tal como julgadas, parecem estar dissociadas do disposto nos arts. 64 e 65 da LREF: decidiu-se que as circunstâncias que justificam o afastamento (do administrador e do devedor), e que estão relacionadas nos incidos do art. 64 da LREF, são meramente exemplificativas, não numerus clausus, e que o termo devedor, para efeito de alijamento do processo de recuperação, deve ser entendido como acionista controlador, não como a própria sociedade.

Acrescente-se, por fim, que a recuperação judicial da VARIG - Viação Aérea Rio-Grandense S.A., da Rio Sul Linhas Aéreas S.A. e da Nordeste Linhas Aéreas S.A. foi convolada em falência em 20.8.2010. 
CAPÍTULO IV - OS PRESSUPOSTOS E O PROCEDIMENTO PARA A NOMEAÇÃO DO GESTOR JUDICIAL 


\section{CAPÍTULO IV - OS PRESSUPOSTOS E O PROCEDIMENTO PARA A NOMEAÇÃO DO GESTOR JUDICIAL}

A LREF, como se disse, manteve a tradição do Direito positivo e dispôs, na parte inicial do art. 64 que, no processo de recuperação judicial, o devedor e os administradores são mantidos na condução dos negócios, sob a fiscalização do administrador judicial e, se houver, do comitê de credores.

Isso não obstante, se se verificar a prática de qualquer um dos atos prescritos nos incisos do mesmo art. 64, afastados serão os administradores ou a própria sociedade empresária devedora, dependendo de quem tiver praticado o ato que se subsumiu na hipótese legal.

Deste dispositivo decorre, assim, que, em princípio, a gestão dos negócios continua a ser exercida pela sociedade empresária (titular de direitos e obrigações) e seus administradores que a presentam, escolhidos na forma do contrato ou do estatuto social. Entretanto, se vier a ser constatada a prática de quaisquer dos atos descritos nos incisos deste mesmo art. 64, a própria devedora ou seu administrador poderá vir a ser afastado da condução dos negócios e substituído (pelo gestor judicial ou por novos administradores eleitos na forma societária, respectivamente), sem que se decrete a falência do devedor.

Isto porque, se "a recuperação judicial tem por objetivo viabilizar a superação da situação de crise econômico-financeira do devedor, a fim de permitir a manutenção da fonte produtora, do emprego dos trabalhadores e dos interesses dos credores, promovendo, assim, a preservação da empresa, sua função social e o estímulo à atividade econômica" (art. 47, LREF), não se justifica a decretação de falência de devedor em crise, mas economicamente viável, apenas porque seus sócios ou administradores praticaram atos que violem obrigações impostas pela LREF ou que contrariem os interesses da devedora ou de seus credores.

Daí que a LREF separou a sorte da empresa da do empresário ou seus administradores: enquanto na revogada Lei de Falências, por exemplo, a condenação de 
um único administrador pela prática de crime falimentar importava na convolação da concordata preventiva em falência (art. 150, inc. VII) e impedia a concessão de concordata suspensiva (art. 111), ainda que a empresa fosse economicamente viável, na atual LREF se um dos administradores for condenado criminalmente, ele será destituído e substituído na forma ajustada no contrato ou estatuto social (art. 64, inc. I e parágrafo único), não se convolando a recuperação judicial em falência.

Destaque-se, por oportuno, que as circunstâncias relacionadas nos incisos do art. 64 da LREF são numerus clausus, de modo que não se admite a aplicação da consequência estabelecida em seu parágrafo único (isto é, a destituição do administrador) e no artigo subsequente (ou seja, o afastamento do devedor, entendido como sociedade empresária devedora) a outros casos não constantes da relação do mencionado art. 64, como destacam LOBO (2007, p. 190) e VERÇOSA (2006 ${ }^{\text {, }}$ p. 32).

Para MUNHOZ (2007, p. 312), a LREF estabeleceu hipóteses muito restritas de afastamento dos administradores e do devedor, e seria recomendável que a lei ampliasse os casos de afastamento para contemplar, por exemplo, a vontade da maioria significativa dos credores ou a prática de atos contrários ao objetivo da recuperação. Entretanto, como as situações que justificam o afastamento são taxativas, somente nos casos expressamente contemplados pela legislação é que o devedor ou seus administradores podem ser alijados da condução da empresa.

Examinando-se os incisos do art. 64 da LREF constata-se, nas palavras de PIMENTA (2006, p. 176), que neles são enumeradas "situações que comprometem a credibilidade pessoal dos administradores ou sócios da sociedade devedora e, em consequência, depõem contra a presunção de boa-fé existente", ou seja, demonstram a falta de idoneidade dos sócios e administradores do devedor.

Acrescente-se ainda que as situações tratadas nos incisos I e VI do mencionado art. 64 da LREF são objetivas e de fácil constatação, pois basta verificar se o administrador foi condenado, por sentença penal transitada em julgado, pela prática de um dos crimes relacionados no inciso I, ou se o plano de recuperação judicial prevê seu afastamento. Entretanto, quanto às circunstâncias previstas nos incisos II, III, IV e V, do mesmo art. 64, a situação é diversa, porquanto a subsunção dos fatos a uma das hipóteses legais exige 
exame casuístico e minucioso da conduta, respeitando-se, sempre, o direito ao contraditório e à ampla defesa ${ }^{159}$.

Verificada a prática, pelo administrador, de qualquer um dos atos descritos nas hipóteses de que tratam os incisos deste art. 64, ele será destituído, e seu substituto será eleito na forma estabelecida no parágrafo único do art. 64. Daí que, se a destituição do administrador se fundar em uma das hipóteses de que tratam os incisos I a V do art. 64, o novo administrador deverá ser nomeado obedecendo-se ao que dispuser o contrato ou o estatuto social. Entretanto, se a destituição constar do plano de recuperação judicial (art. 64, inc. VI, LREF), o substituto será nomeado obedecendo-se ao que estiver previsto no próprio plano. Se o plano, contudo, for omisso quanto à nomeação do substituto, sua eleição será feita na forma ajustada no contrato (estatuto) social.

Por outro lado, consumada a prática, pelos sócios do devedor, de qualquer um dos atos descritos nos incisos do referido art. 64, a sociedade empresária devedora será alijada da condução da atividade empresarial e substituída pelo gestor judicial, sempre eleito pelos credores reunidos em assembleia geral.

\section{A condenação penal transitada em julgado}

O inc. I do art. 64 descreve a primeira situação que, se verificada, importará no afastamento dos administradores ou da sociedade devedora, a saber: "houver sido condenado em sentença penal transitada em julgado por crime cometido em recuperação judicial ou falência anteriores ou por crime contra o patrimônio, a economia popular ou a ordem econômica previstos na legislação vigente." 160

\footnotetext{
${ }^{159}$ Nesse sentido decidiu o TJRS no Agravo de Instrumento no $70035509736,5^{\text {a }}$ Câmara Cível, relator Des. Jorge Luiz Lopes do Canto, j. 24.11.2010, v.u., de cujo acórdão se extrai o seguinte trecho: "Releva ponderar, ainda, que para destituição dos sócios administradores deve ser realizado pedido certo, bem como dadas as causas jurídicas que autorizam o pleito formulado em incidente próprio, elencadas taxativamente na norma legal precitada, de sorte que haja dilação probatória para apurar a responsabilidade daqueles. A par disso, a destituição dos administradores deve observar aos princípios do contraditório e da ampla defesa, portanto, é imprescindível que seja oportunizado aqueles o direito de refutar os fatos que lhes são imputados, bem como produzir prova a esse respeito."

${ }^{160}$ Os crimes contra o patrimônio estão tipificados nos arts. 155 a 180 do Código Penal, enquanto os crimes contra a economia popular estão na Lei $\mathrm{n}^{\circ} 1.521 / 51$ e os crimes contra a ordem econômica nas Leis $\mathrm{n}^{\circ} \mathrm{s}$ $8.137 / 90$ e $8.884 / 94$.
} 
Essa norma da LREF deve ser examinada em conjunto com o art. 48, inc. IV, do mesmo diploma legal, o qual estabelece que somente pode requerer recuperação judicial o devedor que preencher determinados requisitos, entre os quais "não ter sido condenado ou não ter, como administrador ou sócio controlador, pessoa condenada por qualquer dos crimes previstos nesta lei." Em outras palavras, se o administrador ou o sócio controlador da sociedade empresária tiver sido condenado pela prática de crime falimentar, o devedor estará impedido de requerer a recuperação judicial.

Da conjugação desses dispositivos da LREF decorre que (a) se o trânsito em julgado da sentença penal condenatória imposta pela prática de "crime cometido em recuperação judicial ou falência anteriores" ocorrer antes da apresentação do pedido de recuperação judicial, o devedor estará impedido de fazê-lo. Entretanto, (b) se o trânsito em julgado da condenação penal pela prática de "crime cometido em recuperação judicial ou falência anteriores" ocorrer após o requerimento da recuperação judicial, a consequência será o afastamento (b.1) do administrador condenado (e sua substituição por outro na forma dos atos constitutivos do devedor), ou (b.2) da própria sociedade empresária devedora, se condenado tiver sido um de seus sócios.

Por outro lado, se não se tratar de "crime cometido em recuperação judicial ou falência anteriores", mas de "crime contra o patrimônio, a economia popular ou a ordem econômica”, o trânsito em julgado da condenação penal importará no afastamento, conforme o caso, do administrador ou do devedor, ainda que a condenação tenha se tornado definitiva antes da apresentação do pedido de recuperação judicial, pois o trânsito em julgado da sentença penal pela prática desses crimes não impede o devedor de requerer a recuperação.

Acrescente-se ainda, com FONSECA $\left(2009\right.$, p. 435) ${ }^{161}$, que

${ }^{161}$ FONSECA $(2009$, p. 436) esclarece também que a norma do inc. I do art. 64 da LREF contém um erro:
"Na redação dada a Substitutivo da Comissão de Assuntos Econômicos, o inciso I dispunha corretamente
sobre o afastamento decorrente da condenação definitiva por 'crime cometido em recuperação judicial ou
falência anterior', pois a recuperaçãa extrajudicial, por não envolver sacrifício involuntário do direito dos
credores, dispensava todos os mecanismos de proteção desenhados para a recuperação judicial. Contudo, no
último momento da votação da matéria no Plenário do Senado, foi promovida radical modificação - desas-
trada em vários aspectos - no Capítulo VI, que trata da recuperação extrajudicial. Assim, passou-se a admitir,
mesmo na recuperação extrajudicial, a submissão do credor minoritário à decisão da maioria e, concomitan-
temente, incluiu-se entre os crimes dos arts. 168 a 178, as condutas praticadas em recuperação extrajudicial.
Entretanto, não foram feitas as necessárias adaptaçães no restante do texto da Lei, como é o caso do art. 64, I, 
condenações definitivas por crimes contra o patrimônio, a economia popular e a ordem econômica ensejam o afastamento independentemente de estarem relacionados à falência ou a recuperação judicial, assim como os crimes previstos na Lei de Falências e praticados em falência ou recuperação judicial anterior. Igualmente ensejam o afastamento as condenações definitivas por outros crimes, como contrabando, descaminho, sonegação fiscal e falsidade, desde que relacionados à falência ou recuperação judicial, bem como aqueles previstos no Decreto-Lei $n^{\circ} 7.661$, de 1945, por estarem necessariamente relacionados a uma falência anterior.

\section{Os indícios da prática de crime falimentar}

A segunda situação contemplada no art. 64 da LREF e que acarreta o afastamento dos administradores ou da sociedade devedora está em seu inc. II, e refere-se à existência de indícios veementes de ter sido cometido um dos crimes previstos na lei de recuperação de empresas e falências, os quais estão tipificados nos arts. 168 a 178 dessa legislação ${ }^{162}$.

que deveria prever o afastamento também no caso de crimes praticados em recuperação extrajudicial anterior, já que não vemos justificativa para excluí-los. Ao contrário, por tratar-se de procedimento submetido a menor fiscalização e controle, com mais razão a deslealdade deveria ser punida. Como consequência, por tratar-se de um efeito da sentença penal condenatória, a omissão da Lei implica que autores de crimes relacionados à recuperação extrajudicial anterior - com exceção dos previstos na Lei de Falências, tutelados pelo art. 181, I - não poderão ser automaticamente afastados da administração do devedor em recuperação judicial."

162 Os tipos penais previstos na LREF são os seguintes:

Art. 168. Praticar, antes ou depois da sentença que decretar a falência, conceder a recuperação judicial ou homologar a recuperação extrajudicial, ato fraudulento de que resulte ou possa resultar prejuízo aos credores, com o fim de obter ou assegurar vantagem indevida para si ou para outrem. (...) $\S 1^{\circ}$ A pena aumenta-se de 1/6 (um sexto) a 1/3 (um terço), se o agente: I - elabora escrituração contábil ou balanço com dados inexatos; II - omite, na escrituração contábil ou no balanço, lançamento que deles deveria constar, ou altera escrituração ou balanço verdadeiros; III - destrói, apaga ou corrompe dados contábeis ou negociais armazenados em computador ou sistema informatizado; IV - simula a composição do capital social; V - destrói, oculta ou inutiliza, total ou parcialmente, os documentos de escrituração contábil obrigatórios.

Art. 169. Violar, explorar ou divulgar, sem justa causa, sigilo empresarial ou dados confidenciais sobre operações ou serviços, contribuindo para a condução do devedor a estado de inviabilidade econômica ou financeira.

Art. 170. Divulgar ou propalar, por qualquer meio, informação falsa sobre devedor em recuperação judicial, com o fim de levá-lo à falência ou de obter vantagem.

Art. 171. Sonegar ou omitir informações ou prestar informações falsas no processo de falência, de recuperação judicial ou de recuperação extrajudicial, com o fim de induzir a erro o juiz, o Ministério Público, os credores, a assembléia-geral de credores, o Comitê ou o administrador judicial.

Art. 172. Praticar, antes ou depois da sentença que decretar a falência, conceder a recuperação judicial ou homologar plano de recuperação extrajudicial, ato de disposição ou oneração patrimonial ou gerador de obrigação, destinado a favorecer um ou mais credores em prejuízo dos demais.

Art. 173. Apropriar-se, desviar ou ocultar bens pertencentes ao devedor sob recuperação judicial ou à massa falida, inclusive por meio da aquisição por interposta pessoa. 
O indício, segundo estabelece o art. 239 do Código de Processo Penal, é "a circunstância conhecida e provada, que, tendo relação com o fato, autorize, por indução, concluir-se a existência de outra ou outras circunstâncias", ou seja, é "o fato ou a série de fatos, pelos quais se pode chegar ao conhecimento de outros, (...) são circunstâncias que se mostram e se acumulam para a comprovação do fato, assim tido como verdadeiro (...) os indícios dizem-se provas indiretas, porque não vêm por si mesmos, mas, como provas circunstanciais, conciliáveis ou conexas, para evidenciarem o fato que se quer demonstrar e por eles se demonstram." 163

Em outras palavras, para que se afastem o devedor ou seus administradores basta a existência de indícios veementes da ocorrência de crime tipificado na LREF, não sendo necessária sequer a instauração de processo penal, muito menos de sentença condenatória transitada em julgado: o afastamento não é efeito da condenação penal, mas sanção civil imposta com a finalidade de manter a lisura do processo de recuperação judicial (FONSECA, 2009, p. 437), visto que a existência desses indícios denota a falta de idoneidade para a condução da empresa.

Acrescente-se que os indícios que justificam o alijamento devem referir-se à prática de crime falimentar no processo de recuperação judicial em curso, não em procedimento anterior, pois neste último caso o afastamento somente se dará se houver sentença penal condenatória transitada em julgado, nos termos do inc. I do art. 64 da LREF.

Art. 174. Adquirir, receber, usar, ilicitamente, bem que sabe pertencer à massa falida ou influir para que terceiro, de boa-fé, o adquira, receba ou use.

Art. 175. Apresentar, em falência, recuperação judicial ou recuperação extrajudicial, relação de créditos, habilitação de créditos ou reclamação falsas, ou juntar a elas título falso ou simulado.

Art. 176. Exercer atividade para a qual foi inabilitado ou incapacitado por decisão judicial, nos termos desta Lei.

Art. 177. Adquirir o juiz, o representante do Ministério Público, o administrador judicial, o gestor judicial, o perito, o avaliador, o escrivão, o oficial de justiça ou o leiloeiro, por si ou por interposta pessoa, bens de massa falida ou de devedor em recuperação judicial, ou, em relação a estes, entrar em alguma especulação de lucro, quando tenham atuado nos respectivos processos.

Art. 178. Deixar de elaborar, escriturar ou autenticar, antes ou depois da sentença que decretar a falência, conceder a recuperação judicial ou homologar o plano de recuperação extrajudicial, os documentos de escrituração contábil obrigatórios.

${ }^{163}$ Definição extraída do Vocabulário Jurídico, De Plácido e Silva, 1984. 


\section{O dolo, a simulação ou a fraude contra os interesses dos credores}

O inc. III do art. 64 da LREF estabelece a terceira situação cuja ocorrência implica o afastamento dos administradores ou da sociedade devedora, qual seja, se houver agido com dolo, simulação ou fraude contra os interesses dos credores.

O dolo, segundo a clássica definição de BEVILAQUA (1927, p. 331), “é o artifício ou expediente astucioso, empregado para induzir alguém à prática de um acto, que o prejudica, e aproveita ao autor do dólo ou a terceiro", ou seja, consiste no engodo empregado para viciar a vontade de terceiros. Está regulado nos arts. 145 a 150 do Código Civil, e tem como consequência a anulação do negócio jurídico viciado.

A simulação, por sua vez, consiste na prática de ato ou negócio onde as partes escondem, camuflam ou fingem a real intenção. Sua característica, assim, é a divergência entre a vontade e sua declaração, divergência essa que é sempre fruto de conluio, dispondo o parágrafo $1^{\circ}$ do art. 167 do Código Civil que há simulação nos negócios jurídicos quando: "I - aparentarem conferir ou transmitir direitos a pessoas diversas daquelas às quais realmente se conferem, ou transmitem; II - contiverem declaração, confissão, condição ou cláusula não verdadeira; III - os instrumentos particulares forem antedatados, ou pós-datados." A simulação, dispõe o caput do referido art. 167, é causa de nulidade absoluta do negócio jurídico.

A fraude, por fim, novamente de acordo com a lição de BEVILAQUA (1927, p. 348), "é todo acto prejudicial ao credor (eventos damni), por tornar o devedor insolvente ou ter sido praticado em estado de insolvência."

Tanto o dolo, quanto a simulação e a fraude contra credores são vícios do consentimento que justificam o afastamento do devedor ou seus administradores porque a recuperação judicial pressupõe cooperação recíproca entre credores e devedor, o que exige boa-fé de todos os participantes, boa-fé essa que não se verificará no caso da ocorrência de um desses vícios (TOMAZETTE, 2011, p. 229). 
Destaque-se, ainda, que, para FONSECA (2009, p. 439), esse inciso III do art. 64 da LREF deveria contemplar também, como causa de afastamento do devedor e seus administradores, a ocorrência de coação, consistente em ameaça de dano grave e iminente que tenha sido a causa determinante da celebração de determinado negócio jurídico, uma vez que a coação também denota ausência da boa-fé que deve nortear o comportamento das partes.

Porque as hipóteses de afastamento do devedor e seus administradores são taxativas, não exemplificativas, a ocorrência da coação, por si só, não importa no alijamento da condução da atividade empresarial. Entretanto, como destaca o próprio FONSECA (2009, p. 440), o afastamento provavelmente ocorrerá com fundamento no inc. II do art. 64, visto que a coação é elemento de diversos tipos penais.

\section{Os gastos pessoais excessivos}

A alínea "a" do inc. IV do já referido art. 64 da LREF estabelece como causa de afastamento o fato de o devedor ou seu administrador "efetuar gastos pessoais manifestamente excessivos em relação à sua situação patrimonial." Essa conduta, no regime da revogada Lei de Falências (Decreto-Lei ${ }^{\circ}$ 7.661/45), era tipificado como crime falimentar ${ }^{164}$, o que não ocorre no atual regime legal, pois a consequência é apenas o afastamento e a substituição do perdulário.

Porque o dispositivo legal expressamente trata de gastos pessoais, referem-se eles a despesas alheias à atividade empresarial, contraídas no interesse exclusivo do devedor ou de seus administradores, ainda que indiretamente possam beneficiar a empresa a cumprir seu objeto social. A apuração dessa conduta, por óbvio, é casuística, e se faz a partir da situação patrimonial de quem pratica o ato, bem como de seus reflexos para a atividade empresarial ${ }^{165}$.

164 “Art. 186. Será punido o devedor com detenção, de seis meses a três anos, quando concorrer com a falência algum dos seguintes fatos: I - gastos pessoais, ou de família, manifestamente excessivos em relação ao seu cabedal."

165 TOMAZETTE (2011, p. 229) ressalta que "havendo o pedido de recuperação judicial, deve-se presumir a existência da crise. Se ele está em crise e precisa de ajuda para superá-la, não há motivo para permitir que ele use essa ajuda em benefício pessoal e não em benefício da atividade. Assim, se o devedor, apesar da crise, adquire um carro de luxo para uso pessoal, obviamente ele não está cooperando com a superação da crise e, 
A prática dessa conduta justifica o afastamento do empresário individual porque seu patrimônio pessoal confunde-se com o da empresa por ele conduzida. De igual modo e pelos mesmos fundamentos, à esta hipótese de afastamento subsumem-se as condutas do devedor sociedade empresária de responsabilidade ilimitada.

Tratando-se, porém, de sociedade empresária de responsabilidade limitada, como é o caso da limitada, da sociedade por ações e da empresa individual de responsabilidade limitada, a prática desses atos não justifica o afastamento e substituição dos administradores e do devedor, quer porque o patrimônio dos sócios não se confunde com o da sociedade (de modo que se os sócios contraírem obrigações pessoais excessivas, nenhum efeito haverá para o patrimônio da empresa em dificuldade), quer porque os administradores somente respondem se violarem os deveres fiduciários para com $\mathrm{o}$ devedor cujos negócios conduzem, violação essa que não se verificará se os gastos excessivos comprometem apenas o patrimônio pessoal do administrador, não o da empresa (FONSECA, 2009, p. 441).

5. As despesas injustificáveis

A alínea "b" do inc. IV do art. 64 da LREF estabelece como causa de afastamento se o devedor ou seu administrador "efetuar despesas injustificáveis por sua natureza ou vulto, em relação ao capital ou gênero do negócio, ao movimento das operações e a outras circunstâncias análogas". De modo idêntico à hipótese da alínea "a" acima tratada (gastos pessoais excessivos), a conduta ora examinada também era tipificada como crime falimentar na revogada Lei de Falências (Decreto-Lei $n^{\circ} 7.661 / 45$ ) ${ }^{166}$, o que não se verifica na LREF.

Este caso de afastamento e substituição tem como pressuposto a falta de cooperação do devedor ou de seus administradores para com a recuperação da empresa em

por isso, deve ser afastado. Lembre-se, porém, que apenas gastos considerados manifestamente excessivos podem ensejar o afastamento, o que dependerá uma análise caso a caso.”

166 “Art. 186. Será punido o devedor com detenção, de seis meses a três anos, quando concorrer com a falência algum dos seguintes fatos: (...) II - despesas gerais do negócio ou da emprêsa injustificáveis, por sua natureza ou vulto, em relação ao capital, ao gênero do negócio, ao movimento das operações e a outras circunstâncias análogas." 
dificuldade: "equívocos administrativos evidentes, incompatíveis com padrões mínimos de eficiência e diligência exigidos na atividade empresarial” (FONSECA, 2009, p. 441).

6.

A descapitalização injustificada da empresa devedora

A conduta descrita na alínea "c" do inc. IV do art. 64 da LREF, cuja prática acarreta o afastamento do devedor ou seus administradores, complementa a hipótese de que trata a alínea "b" ("efetuar despesas injustificáveis por sua natureza ou vulto, em relação ao capital ou gênero do negócio, ao movimento das operações e a outras circunstâncias análogas”), pois é causa de substituição a prática de atos que importem “descapitalizar injustificadamente a empresa ou realizar operações prejudiciais ao seu funcionamento regular".

A descapitalização injustificada do devedor nada mais é do que a dilapidação do patrimônio da empresa, sem redução da garantia outorgada a credores ou ocultação de bens, pois se a intenção foi atingir esses efeitos, configurar-se-á fraude contra credores ou o crime tipificado no art. 168 da LREF, o que, por si só, já importa no afastamento do devedor ou seu administrador na forma dos incisos II e III do art. 64 (FONSECA, 2009, p. 442).

\section{A simulação e a omissão de crédito}

A concessão da recuperação judicial está condicionada à aprovação do plano apresentado pelo devedor. Para tanto, necessita ele comprovar a viabilidade econômica da empresa, razão pela qual o art. 51 da $\operatorname{LREF}^{167}$ contém extensa lista dos documentos que

${ }^{167}$ Art. 51. A petição inicial de recuperação judicial será instruída com: I - a exposição das causas concretas da situação patrimonial do devedor e as razões da crise econômico-financeira; II - as demonstrações contábeis relativas aos 3 (três) últimos exercícios sociais e as levantadas especialmente para instruir o pedido, confeccionadas com estrita observância da legislação societária aplicável e compostas, obrigatoriamente de: a) balanço patrimonial; demonstração de resultados acumulados; demonstração do resultado desde o último exercício social; d) relatório gerencial de fluxo de caixa e de sua projeção; III - a relação nominal completa dos credores, inclusive aqueles por obrigação de fazer ou de dar, com a indicação do endereço de cada um, a natureza, a classificação e o valor atualizado do crédito, discriminando sua origem, o regime dos respectivos vencimentos e a indicação dos registros contábeis de cada transação pendente; IV - a relação integral dos empregados, em que constem as respectivas funções, salários, indenizações e outras parcelas a que têm direito, com o correspondente mês de competência, e a discriminação dos valores pendentes de pagamento; V certidão de regularidade do devedor no Registro Público de Empresas, o ato constitutivo atualizado e as atas de nomeação dos atuais administradores; VI - a relação dos bens particulares dos sócios controladores e dos administradores do devedor; VII - os extratos atualizados das contas bancárias do devedor e de suas eventu- 
deverão instruir a petição inicial, de modo a transmitir aos credores informações a respeito de sua efetiva situação econômico-financeira.

Tanto assim é que, segundo esclarece SZTAJN (2007, p. 248), o art. 51 da LREF detalhou de forma exaustiva a relação de documentos que deve instruir a petição inicial porque quem dispõe de melhor informação sempre tem vantagem na elaboração de estratégia negocial, e como o devedor conhece seu negócio, a forma de diminuir a assimetria entre ele e os credores é prestando informações, razão pela qual é necessário examinar não apenas se a empresa cumpriu sua obrigação de juntar os documentos relacionados na lei, mas também averiguar a prestabilidade dessas informações.

A apresentação de todos esses documentos, assim, é obrigatória, não podendo o juiz dispensar o devedor de juntar algum ou alguns deles aos autos, pois têm por finalidade dar aos credores informações precisas a respeito do real estado do devedor, de modo a permitir que possam fazer uma correta análise de sua situação econômico-financeira e, consequentemente, decidir a respeito da viabilidade da superação das dificuldades econômicas, bem como do plano de recuperação.

Bem por isso, como destaca COELHO (2008, p. 144), o despacho que determina o processamento do pedido de recuperação judicial (art. 52 da LREF) somente poderá ser proferido depois que a petição inicial estiver instruída com todos os documentos e informações exigidos pelo art. 51 da LREF.

Daí que, se o devedor não instruir a petição inicial do pedido de recuperação judicial com todos os documentos exigidos pelo art. 51 da LREF, o juiz poderá concederlhe prazo para fazê-lo, da mesma forma que já ocorria se a petição inicial de uma concordata preventiva não estivesse acompanhada de todos os documentos relacionados nos arts. 159 e 160 da revogada Lei de Falências (Decreto-lei no $7.661 / 45)^{168}$.

ais aplicações financeiras de qualquer modalidade, inclusive em fundos de investimento ou em bolsas de valores, emitidos pelas respectivas instituições financeiras; VIII - certidões dos cartórios de protestos situados na comarca do domicílio ou sede do devedor e naquelas onde possuir filial; IX - a relação, subscrita pelo devedor, de todas as ações judiciais em que este figure como parte, inclusive as de natureza trabalhista, com a estimativa dos respectivos valores demandados.

${ }^{168}$ Embora o art. 161 da revogada Lei de Falências dispusesse que o juiz devia declarar a falência, no prazo de 24 horas, "se o pedido (de concordada preventiva) não estiver formulado nos termos da lei, não vier devidamente instruído, ou quando estiver inequivocamente caracterizada a fraude", os juízes concediam 
RESTIFFE (2008, p. 247) alerta, porém, que se o devedor, apesar de instado a complementar a documentação que deveria instruir a petição inicial, não cumprir a determinação judicial, a consequência de sua desídia não será a decretação da falência, mas apenas o indeferimento da petição inicial e a extinção do processo de recuperação judicial sem resolução do mérito ${ }^{169}$.

Pois bem, entre os documentos que a LREF exige instrua o pedido de recuperação judicial está "a relação nominal completa dos credores, inclusive aqueles por obrigação de fazer ou de dar, com a indicação do endereço de cada um, a natureza, a classificação e o valor atualizado do crédito, discriminando sua origem, o regime dos respectivos vencimentos e a indicação dos registros contábeis de cada transação pendente" (art. 51, inc. III).

A última alínea (“d”) do inc. IV do art. 64 da LREF, por sua vez, estabelece que será afastado e substituído o devedor e seu administrador que "simular ou omitir créditos ao apresentar a relação de que trata o inciso III do caput do art. 51 desta Lei, sem relevante razão de direito ou amparo de decisão judicial", daí decorrendo que a causa do afastamento é o dolo do administrador ou devedor que simula ou omite créditos. O que se busca, assim, é manter a lisura do procedimento de recuperação judicial.

A relevância da correção da lista de credores é que no sistema da LREF a habilitação e a impugnação de créditos são procedimentos conduzidos pelo administrador judicial, não pelo juiz, que somente examinará um crédito em especial se houver impugnação à relação de credores apresentada pelo administrador judicial. Ademais, se o quadro geral de credores não tiver sido elaborado até a data de realização de assembleia de

prazo ao requerente para juntar todos os documentos exigidos pela lei, tendo o STJ, no Recurso Especial $\mathrm{n}^{\circ}$ 459.827-SP, rel. Min. Carlos Alberto Menezes Direito, j. 17.06.2003, v.u., decidido que "não viola o art. 161 da Lei de Falências o deferimento de prazo razoável para que a empresa possa apresentar a documentação completa para instruir o pedido de concordata."

169 RESTIFFE (2008, p. 247) afirma literalmente que "ao juiz, verificando que o devedor não instruiu a petição inicial com os documentos indispensáveis, não preenchendo, portanto, os requisitos do art. 283 do Código de Processo Civil, cabe, ante a desídia, determinar a emenda ou a complementação da petição inicial, no prazo legal, sob pena de seu indeferimento, com a consequente extinção do processo sem resolução do mérito, nos termos dos arts. 267, I, 284, parágrafo único, e 295 do Código de Processo Civil.” 
credores, o direito de voto será exercido a partir da relação apresentada pelo devedor (FONSECA, 2009, p. 442).

Exatamente por isso é que a referida alínea "d" do inc. IV do art. 64 pune com afastamento a desídia, a má-fé, do devedor ou seu administrador que dolosamente altera ou simula créditos ${ }^{170}$.

\section{8. $\quad O$ descumprimento da obrigação de prestar informações}

Preenchidos os requisitos do art. 48 da LREF e estando a petição inicial instruída com todos os documentos relacionados no art. 51 da mesma lei, o juiz deferirá o processamento da recuperação judicial (art. 52), ocasião em que nomeará o administrador judicial (inc. I), dispensará o devedor de apresentar certidões negativas para exercer sua atividade (inc. II), suspenderá o processamento de ações contra o devedor (inc. III), determinará ao devedor que preste contas mensalmente enquanto perdurar a recuperação judicial, "sob pena de destituição de seus administradores" (inc. IV), ordenará a intimação do Ministério Público e das Fazendas Federal, Estadual e Municipal (inc. V) e mandará publicar edital para dar ciência aos credores e a todos os interessados do pedido de recuperação ju$\operatorname{dicial}\left(\S 1^{\circ}\right)$.

Acrescenta o art. 64, inc. V, da LREF, por seu turno, que será afastado o devedor ou seu administrador que "negar-se a prestar informações solicitadas pelo administrador judicial ou pelos demais membros do Comitê", daí decorrendo que o afastamento se dará não apenas no caso de não apresentação das contas mensais, mas também no caso de negativa à prestação de quaisquer informações adicionais que venham a ser requeridas pelo

\footnotetext{
${ }^{170}$ FONSECA (2009, p. 443) destaca que "a Lei pune com severidade a má-fé do devedor ou de seu administrador na elaboração da lista de credores, não só proibindo-o de continuar à frente dos negócios, mas também tipificando como crimes a sonegação e a omissão de informações ou a prestação de informações falsa para induzir a erro (art. 171), bem como a apresentação de relação de créditos falsa (art. 174). Como o inciso II do art. 64 já prevê o afastamento do administrador sobre o qual pesem indícios veementes de crime previsto na Lei $n^{\circ} 11.101$, o inciso IV, $d$, dispensa a comprovação da intenção de fraudar ou de induzir erro para a destituição do administrador transgressor, bastando a inexistência de relevante razão de direito ou de sentença judicial embasando a decisão de excluir ou de incluir crédito à relação do art. 51, III.”
} 
administrador judicial (na forma do art. 22, inciso I, alínea “d”, da $L R E F^{171}$ ), ou por qualquer membro do comitê de credores.

A punição do devedor ou seus administradores se justifica porquanto "corrobora a exigência de transparência nas atividades do devedor em recuperação judicial, facilitando o acesso do administrador judicial e do Comitê de Credores às informações necessárias ao cumprimento de seu poder-dever de fiscalização" (FONSECA, 2009, p. 444).

\section{O afastamento do administrador e do devedor previsto no plano de recuperação judicial}

A partir da data da intimação do devedor do deferimento do processamento da recuperação judicial, ele tem o prazo de 60 dias para apresentar o plano de recuperação judicial, consubstanciado em diversos documentos, discriminados no art. 53 da LREF, apresentação essa cuja finalidade é possibilitar aos credores que examinem se a solução proposta pelo devedor é econômica e financeiramente viável, bem como se permitirá a superação da crise e a recuperação da empresa.

Segundo o referido art. 53 da LREF, o plano de recuperação deverá conter: "I discriminação pormenorizada dos meios de recuperação a ser empregados, conforme o art. 50 desta Lei e seu resumo; II - demonstração de sua viabilidade econômica; e III - laudo econômico-financeiro e de avaliação dos bens e ativos do devedor, subscrito por profissional legalmente habilitado ou empresa especializada."

Para LOBO (2007, p. 159), a lei exige que o devedor instrua o plano de recuperação com esses documentos com a finalidade de comprovar que a manutenção da empresa trará mais benefícios do que a decretação de sua falência, tanto para os credores quanto para os trabalhadores e consumidores.

COELHO (2008, p. 158), por sua vez, salienta que, em todo o processo de recuperação judicial, o plano é a peça mais importante, pois dele depende o sucesso ou não

${ }^{171}$ Art. 22. Ao administrador judicial compete, sob a fiscalização do juiz e do Comitê, além de outros deveres que esta Lei lhe impõe: - I - na recuperação judicial e na falência: (...) d) exigir dos credores, do devedor ou seus administradores quaisquer informações. 
da superação da crise financeira, a preservação da atividade econômica e o cumprimento de sua função social. Um bom plano de recuperação não é garantia absoluta de que o devedor superará sua crise econômica, pois inúmeros outros fatores poderão influir no sucesso econômico da empresa, tais como elementos macroeconômicos e o acirramento da concorrência, mas haverá possibilidade de o plano ser um sucesso. Entretanto, se o plano não for consistente, e tiver sido apresentado apenas para cumprir a exigência legal, neste caso, os credores não o aprovarão ou, se o aprovarem, sua implementação não será suficiente para a superação da crise da empresa, o que importará, em qualquer das hipóteses, na decretação de sua falência.

Na elaboração do plano o devedor tem liberdade para decidir quais meios serão empregados para a recuperação econômico-financeira da empresa, destacando RESTIFFE (2008, p. 212), contudo, que a liberdade é plena, mas não ilimitada, pois a própria legislação falimentar impõe alguns limites à liberdade do devedor de formular o plano.

Alguns desses limites são de ordem pública e não admitem convenção em contrário, destacando-se, por exemplo, as normas do art. 54 da LREF, caput e parágrafo único, que obrigam o devedor a pagar (a) os créditos decorrentes da legislação do trabalho ou derivados de acidentes de trabalho vencidos até a data do pedido de recuperação judicial, no prazo máximo de um ano; e (b) os créditos de natureza estritamente salarial vencidos nos três meses anteriores ao pedido de recuperação judicial, até o limite de cinco salários mínimos por trabalhador, no prazo máximo de trinta dias.

Outros limites à liberdade do devedor na elaboração do plano não são de ordem pública, e podem ser objeto de convenção entre as partes, destacando-se, por exemplo, as normas dos parágrafos $1^{\circ}$ e $2^{\circ}$ do art. 50 da LREF, que estabelecem, respectivamente, que "na alienação de bem objeto de garantia real, a supressão da garantia ou sua substituição somente serão admitidas mediante aprovação expressa do credor titular da respectiva garantia" e "nos créditos em moeda estrangeira, a variação cambial será conservada como parâmetro de indexação da correspondente obrigação e só poderá ser afastada se o credor titular do respectivo crédito aprovar expressamente previsão diversa no plano de recuperação judicial." 
A própria LREF apresenta, em seu art. $50^{172}$, um rol exemplificativo de possíveis medidas que poderão ser empregadas pelo devedor em busca do soerguimento através da recuperação judicial.

Comentando este dispositivo da LREF, ressalta SZTAJN (2007, p. 232) que a enumeração dos possíveis meios que poderão ser adotados para a superação da crise econômica da empresa é meramente exemplificativa, pois outras medidas poderão ser empregadas, além, é óbvio, da possível combinação de dois ou mais meios previstos nos incisos do mencionado art. 50.

No mesmo sentido é a opinião de LOBO (2007, p. 141) que, após afirmar que a LREF permite o emprego de outras medidas para a reestruturação e o saneamento da empresa em crise, classifica os modos de recuperação relacionados no art. 50 em meios de reestruturação:

(a) do poder de controle, o que inclui: (a.1) a alienação, a consolidação e o compartilhamento do poder de controle (art. 50, inc. III, LREF); (a.2) a eleição de administradores indicados pelos credores (art. 50, inc. V, LREF); (a.3) atribuição de poder de veto aos credores (art. 50, inc. V, LREF); (a.4) a constituição de sociedade de credores (art. 50, inc. X, LREF); (a.5) o usufruto da empresa (art. 50, inc. XIII, LREF); e (a.6) o usufruto das quotas ou ações (arts. 1.394 do Código Civil e 40 da Lei das Sociedades por Ações);

(b) financeira, o que inclui: (b.1) a dilação de prazos de obrigações e dívidas (art. 50, inc. I, LREF); (b.2) a remissão total os parcial das dívidas (art. 50, caput, LREF); (b.3) a dilação

\footnotetext{
172 Art. 50. Constituem meios de recuperação judicial, observada a legislação pertinente a cada caso, dentre outros: I - concessão de prazos e condições especiais para pagamento das obrigações vencidas ou vincendas; II - cisão, incorporação, fusão ou transformação de sociedade, constituição de subsidiária integral, ou cessão de cotas ou ações, respeitados os direitos dos sócios, nos termos da legislação vigente; III - alteração do controle societário; IV - substituição total ou parcial dos administradores do devedor ou modificação de seus órgãos administrativos; V - concessão aos credores de direito de eleição em separado de administradores e de poder de veto em relação às matérias que o plano especificar; VI - aumento do capital social; VII - trespasse ou arrendamento de estabelecimento, inclusive à sociedade constituída pelos próprios empregados; VIII redução salarial, compensação de horários e redução da jornada, mediante acordo ou convenção coletiva; IX - dação em pagamento ou novação de dívidas do passivo, com ou sem constituição de garantia própria ou de terceiro; X - constituição de sociedade de credores; XI - venda parcial dos bens; XII - equalização de encargos financeiros relativos a débitos de qualquer natureza, tendo como termo inicial a data da distribuição do pedido de recuperação judicial, aplicando-se inclusive aos contratos de crédito rural, sem prejuízo do disposto em legislação específica; XIII - usufruto da empresa; XIV - administração compartilhada; XV emissão de valores mobiliários; XVI - constituição de sociedade de propósito específico para adjudicar, em pagamento dos créditos, os ativos do devedor.
} 
ou remissão parcial das dívidas (art. 50, caput e inc. I, LREF); (b.4) o aumento do capital social (art. 50, inc. VI, LREF); (b.5) a dação em pagamento e a novação de dívidas (art. 50, inc. IX, LREF); (b.6) a equalização dos encargos financeiros (art. 50, inc. XII, LREF); (b.7) a emissão de valores mobiliários (art. 50, inc. XV, LREF); (b.8) a conversão em reais das dívidas em moeda estrangeira (art. 50, § $2^{\circ}$, LREF);

(c) econômica, o que inclui: (c.1) a cessão de quotas ou ações (art. 50, inc. II, LREF); (c.2) o trespasse ou arrendamento de estabelecimento (art. 50, inc. VII, LREF); (c.3) a alienação parcial de bens (art. 50, inc. XI e XVI, LREF);

(d) administrativa, o que inclui (d.1) a substituição dos administradores (art. 50, inc. IV, LREF); (d.2) a modificação dos contratos de trabalho (art. 50, caput e inc. VIII, LREF); e (d.3) a administração compartilhada (art. 50, inc. XIV, LREF);

(e) societária, contemplada no art. 50, inc. II, da LREF; e

(f) complexa ou híbrida ou mista, se o plano contemplar a implementação simultânea de vários dos meios de recuperação previstos no referido art. 50 da Lei de Recuperação de Empresas e Falência.

De todos esses possíveis meios de superação da crise econômico-financeira do devedor, interessam, para o objeto desta dissertação, os relacionados à administração do devedor e à gestão da empresa, sendo importante lembrar, uma vez mais, que a recuperação judicial não implica a automática destituição dos administradores da sociedade empresária, os quais permanecem no exercício de seus cargos mesmo após o deferimento do processamento da recuperação. Entretanto, o devedor pode incluir no plano de recuperação judicial, entre outras medidas, a substituição dos administradores, a redução de seus poderes, a concessão de direito de veto, o compartilhamento da administração e até mesmo o afastamento do próprio devedor.

De fato, a relação meramente exemplificativa constante do art. 50 da LREF inclui, entre os possíveis meios de recuperação econômico-financeira da empresa a "substituição total ou parcial dos administradores do devedor ou modificação de seus órgãos administrativos" (inc. IV), a "concessão aos credores de direito de eleição em separado de 
administradores e de poder de veto em relação às matérias que o plano especificar" (inc. V) e a "administração compartilhada" (inc. XIV).

É óbvio, contudo, que essas modificações na administração do devedor, assim como o afastamento do devedor e a nomeação de gestor judicial, isoladamente, não permitirão a superação das dificuldades financeiras, pois essas alterações, embora integrem a relação do art. 50 da LREF, sequer podem ser consideradas meios de recuperação, uma vez que a substituição dos administradores, ou mesmo a administração compartilhada, são apenas instrumentos para a implementação do plano de recuperação. Se do plano constasse como meio de recuperação apenas modificações na administração, o processo de recuperação seria absolutamente desnecessário, bastando a prática, pelo próprio devedor, de alguns poucos atos societários (CASTRO, 2006, p. 201).

Assim, qualquer que seja o meio de recuperação proposto pelo devedor, ele não contemplará apenas alterações na gestão da empresa, ainda que a medida proposta seja a administração compartilhada ou o direito de os credores elegerem um ou alguns dos administradores: as modificações na condução do negócio são insuficientes para a superação da crise econômica, de modo que o plano também deve, obrigatoriamente, contemplar outros modos de recuperação, tais como parcelamentos de débitos, concessões de prazo e/ou descontos, conversão de créditos em participações societárias etc., ou seja, o plano deverá prever a forma pela qual os interesses dos credores serão satisfeitos.

Acrescente-se que para COELHO (2008, p. 136),

além da substituição dos administradores, pode ser mostrar útil à reorganização da atividade econômica a modificação dos órgãos societários (p. ex.: criação de comitês especializados nos conselhos de Administração ou de conselhos consultivos) ou mesmo algum grau de ingerência dos credores na administração da sociedade empresária em crise, com poderes de indicar diretores ou obstar determinadas decisões. Por se tratar também de matéria sensível aos interesses do controlador e dos diretores da devedora, é medida de recuperação mais comum em planos alternativos.

Em outras palavras, para COELHO é mais comum que as modificações dos órgãos societários, como meio de recuperação, decorram de sugestões que venham a ser apresentadas pelos credores para se modificar o plano elaborado pelo devedor. 


\subsection{Substituição total ou parcial dos administradores do devedor ou modificação de seus órgãos administrativos}

O inciso IV do art. 50 da LREF prevê, como um dos meios de recuperação judicial, a substituição total ou parcial dos administradores ou a modificação de seus órgãos administrativos. Este modo de recuperação, a rigor, não deveria integrar a relação exemplificativa do art. 50 da lei falimentar, uma vez que, independentemente de estar ou não em recuperação judicial, o devedor tem o direito de substituir seus administradores ou de implementar alterações em sua estrutura administrativa.

Assim é que, para substituir um, alguns, ou até mesmo todos os seus administradores, basta que o devedor, se for uma sociedade limitada, obedeça aos quóruns de que tratam os arts. $1.061,1.063, \S 1^{\circ}, 1.071$, inc. II, III e V, 1.076, inc. I e II, todos do Código Civil e (a) promova uma alteração do contrato social na hipótese de o administrador, sócio ou não, ter sido nomeado no próprio instrumento de contrato social, ou (b) promova a destituição e nomeação de outros em instrumento separado, caso o administrador, sócio ou não, tenha sido eleito em documento outro que não o contrato social.

Caso, contudo, o devedor seja uma sociedade por ações, a substituição, total ou parcial, dos administradores, se faz por deliberação (a) em assembleia geral, quer para escolher novos diretores se a companhia não contar com conselho de administração, quer para eleger novos conselheiros, se a sociedade constar com este órgão, ou (b) do próprio conselho de administração, que é o órgão que tem competência para eleger os administradores nas companhias onde o estatuto prevê a existência deste órgão.

De todo modo, como a substituição total ou parcial dos administradores de que trata o inc. IV do art. 50 da LREF se faz por deliberação exclusiva dos sócios, acionistas ou conselheiros, independentemente da vontade ou do voto dos credores, esta substituição pode ocorrer a qualquer momento e por simples vontade da sociedade empresária devedora, ainda que não conste do plano de recuperação apresentado aos credores (CASTRO, 2006, p. 202). 
A parte final do inciso IV do art. 50 da LREF, por sua vez, estabelece como meio de recuperação a modificação dos órgãos administrativos da sociedade empresária devedora. Neste caso, o devedor pode, independentemente do que dispuser o plano de recuperação judicial e sem consultar seus credores, alterar seus órgãos administrativos para, por exemplo, reduzir o número de diretores ou criar conselhos consultivos.

Entretanto, se a modificação nos órgãos de administração proposta pelo devedor no plano de recuperação judicial contemplar a participação dos credores na gestão da empresa, ainda que apenas em um conselho cuja competência seja simplesmente consultiva ou de fiscalização, nesta hipótese, o devedor deverá obedecer rigorosamente o que dispuser o plano, sob pena de sua recuperação judicial ser convolada em falência.

É necessário acrescentar, porém, que como a norma constante do caput do art. 50 da LREF dispõe que na implementação dos meios de recuperação propostos pelo devedor deverá ser "observada a legislação pertinente a cada caso", resta claro que para se efetuar modificações na estrutura dos órgãos de administração da sociedade empresária será necessária, obrigatoriamente, a realização de reunião de sócios e consequente modificação do contrato social, se se tratar de sociedade limitada, ou a realização de assembleia geral na qual se deliberará a reforma do estatuto social, se a devedora for uma companhia.

\subsection{Concessão aos credores de direito de eleição em separado de administradores e de poder de veto em relação às matérias que o plano especificar}

A parte inicial do inciso $\mathrm{V}$ do art. 50 da LREF prevê, como um dos meios de recuperação judicial, a concessão aos credores de direito de eleição em separado de administradores, o que inclui tanto os diretores quanto os conselheiros.

Porque o caput do art. 50 da LREF dispõe que na implementação dos meios de recuperação deve ser "observada a legislação pertinente a cada caso", é necessário analisar quais os requisitos para a implementação desse meio de recuperação, tanto na limitada quanto na sociedade por ações. 


\subsubsection{A concessão aos credores de direito de eleição em separado de administradores na sociedade limitada}

Da conjugação dos artigos 1.061, 1.063, § 1º 1.071 , inc. II, III e V e 1.076, inc. I e II, todos do Código Civil, decorre que na sociedade limitada apenas os sócios têm o direito de votar na eleição e na destituição dos administradores. Em consequência, não se concebe que a atribuição aos credores do direito de "eleger" em separado um, alguns, ou até mesmo todos os administradores se dê mediante modificação do contrato social, porquanto violaria não apenas o disposto nos artigos do Código Civil acima indicados, como também a norma constante do próprio caput do art. 50 da LREF.

Daí que, na realidade, nesse meio de recuperação judicial os credores não têm o direito de eleger administrador algum, mas têm apenas o direito de indicar quem os sócios deverão eleger como administrador da sociedade, sob pena de a recuperação judicial ser convolada em falência (arts. 61, § $1^{\circ}$ e 73, inc. IV, da LREF). Quem os credores têm poder para eleger diretamente é apenas o gestor judicial, cuja escolha, por expressa disposição legal, compete aos credores reunidos em assembleia geral.

Assim, para a implantação desse meio de recuperação judicial será necessário que os credores reúnam-se em assembleia e elejam a(s) pessoa(s) que deverá(ao) ser nomeada(s) administrador(es) da sociedade. Em seguida, sob pena de convolação da recuperação judicial em falência, os sócios deverão reunir-se e eleger, como administrador(es) da limitada, a(s) pessoa(s) indicada(s) pelos credores.

Quem elege o administrador, assim, são apenas os sócios. Os credores, se esse meio de recuperação judicial for implementado, apenas indicam, em separado, quem os sócios deverão nomear como administrador, sob pena de convolação da recuperação judicial em falência por descumprimento do plano de recuperação. Não se faz necessário, assim, modificar-se o contrato social da limitada para a implementação desse meio de recuperação.

Na hipótese, contudo, de a nomeação do administrador da limitada ser feita no próprio contrato social, neste caso, é óbvio que será necessário alterar o contrato para que 
os sócios destituam os antigos administradores e nomeiem os novos, conforme indicado pelos credores.

Da mesma forma, se o contrato social não admitir administrador que não seja quotista, nesta hipótese também será necessário modificar-se o contrato social. Isto porque, os credores a quem se atribuírem o direito indicar, em separado, quem deverá ser eleito administrador, certamente não vão querer a eleição de um sócio, mas alguém da confiança da maioria dos credores. Daí a necessidade de reformar-se o contrato social da limitada para que seja possível a nomeação de administrador não sócio.

\subsubsection{A concessão aos credores de direito de eleição em separado de administradores na sociedade por ações}

A mesma regra também é aplicável para as sociedades por ações, porquanto quem tem direito de voto são os acionistas (e os conselheiros em determinadas matérias), não os credores. Repita-se: os credores, por expressa disposição legal, têm poder para eleger o gestor judicial, não os administradores do devedor.

Bem por isso, ao comentar a respeito da administração compartilhada prevista como meio de recuperação judicial no inc. XIV do art. 50 da LREF, CASTRO (2006, p. 212) afirma que, nas assembleias gerais e nas reuniões de conselho, os acionistas e os conselheiros, respectivamente, deverão obedecer ao plano de recuperação e eleger "as pessoas indicadas pelos credores, que, a propósito, não participam dos conclaves."

Por esta razão, para que seja possível a eleição de administrador indicado pelos credores não é necessária qualquer alteração do estatuto social.

Deste modo, se a companhia não contar com conselho de administração, os credores deverão reunir-se em assembleia e eleger a(s) pessoa(s) que deverá(ao) ser nomeada(s) diretor(es). Em seguida, sob pena de convolação da recuperação judicial em falência, os acionistas deverão reunir-se em assembleia geral e eleger, como diretor(es) da companhia, a(s) pessoa(s) indicada(s) pelos credores. 
Igualmente, se o estatuto social dispuser que a administração da companhia será exercida pela diretoria e por um conselho de administração, não será necessário modificar-se o estatuto social: os credores escolherão a(s) pessoa(s) que deverá(ão) ser nomea$\mathrm{da}(\mathrm{s})$ administrador(es), quer seja diretor quer seja conselheiro. Ato contínuo, se o direito dos credores for de indicar conselheiro(s), os acionistas reunir-se-ão e elegerão membro do conselho a(s) pessoa(s) indicada(s) pelos credores e(ou) se o direito dos credores for de indicar diretor(es), os conselheiros reunir-se-ão e elegerão como diretor(es) a(s) pessoa(s) indicada(s) pelos credores.

Quer se trate de conselheiro, quer se trate de diretor, não será necessário modificar-se o estatuto social, pois o direito de voto incumbe exclusivamente aos acionistas (para as matérias de competência da assembleia geral) e aos conselheiros (para as matérias de competência do Conselho de Administração), cabendo aos credores apenas o direito de indicar quem deverá ser eleito. Se a pessoa indicada não for eleita, a sociedade poderá ter sua recuperação judicial convolada em falência, nos termos dos arts. $61, \S 1^{\circ}$ e 73 , inc. IV, da LREF.

É até possível conceber-se a transferência aos credores, fiduciariamente, da titularidade de ações de modo a permitir que eles efetivamente elejam, em separado, um ou algum dos administradores. No entanto, para o exercício desse direito, seria necessário criar-se uma classe especial de ações e atribuir-se a essa classe o direito de eleger, em separado, um, alguns ou todos os administradores.

Esta solução, porém, é muito mais onerosa para a devedora, porquanto implica modificação do estatuto social, alteração da composição acionária, eventual celebração de acordo de acionistas de modo a limitar o direito atribuído às ações que serão de titularidade dos credores, indicação pelos credores de quem receberá as ações (pois inviável é transferência de ações a todos os credores) etc.

Não se ignora, por outro lado, que a própria Lei das Sociedades por Ações estabelece uma exceção ao direito exclusivo dos acionistas de votar na eleição dos conselheiros da companhia. Trata-se do disposto no parágrafo único do art. 140, segundo o qual "o estatuto poderá prever a participação no conselho (de administração) de representantes dos 
empregados, escolhidos pelo voto destes, em eleição direta, organizada pela empresa, em conjunto com as entidades sindicais que os representem."

Ocorre que, por se tratar de uma exceção, esta norma deve ser interpretada restritivamente, de modo que não é possível modificar-se o estatuto social para atribuir-se direito de voto aos credores, mesmo que seja para o cumprimento de plano de recuperação judicial.

Como se viu, portanto, quer se trate de limitada, quer se trate de sociedade por ações, a atribuição aos credores do direito de "eleição" em separado de um, alguns, ou até mesmo todos os administradores (na realidade, o direito é de indicar ${ }^{173}$ ) independe de qualquer alteração no contrato ou no estatuto social, salvo se se tratar (a) de administrador de sociedade limitada nomeado no próprio contrato social, ou (b) de incluir no contrato social da limitada a possibilidade de o administrador não ser sócio.

\subsection{A concessão aos credores de poder de veto em relação às matérias especificadas no plano de recuperação judicial}

A parte final do inc. $\mathrm{V}$ do art. 50 da LREF estabelece como um possível meio de recuperação judicial a atribuição aos credores de "poder de veto em relação às matérias que o plano especificar". Porque a relação que integra o art. 50 da LREF é meramente exemplificativa, duas são as possíveis interpretações do disposto neste inciso V: atribuição aos credores de poder de veto em relação a determinadas questões ou atribuição aos administradores "eleitos em separado" pelos credores de poder de veto em relação a certas matérias.

Em qualquer uma dessas hipóteses, porém, não se faz necessário modificar o contrato social (da limitada), o estatuto social (da companhia), nem as normas internas que regem as deliberações e as manifestações dos órgãos de administração, quer a diretoria, quer o conselho de administração.

\footnotetext{
${ }^{173}$ Ao comentar o meio de recuperação judicial previsto no inc. V do art. 50 da LREF, COELHO (2008, p. 136) expressamente afirma "poderes de indicar diretores ..."
} 
Com efeito, se se tratar de atribuição de poder de veto aos próprios credores, para a implementação deste meio de recuperação judicial basta que os credores se reúnam e deliberem se concordam ou não com a prática, pela sociedade em recuperação judicial, do ato cujo poder de veto lhes foi atribuído no plano. Se os credores vetarem a prática do ato, mas a sociedade desrespeitar o veto, a recuperação judicial poderá ser convolada em falência, nos termos dos arts. $61, \S 1^{\circ}$ e 73 , inc. IV, da LREF, uma vez que o plano aprovado terá sido violado.

Da mesma forma, se o poder de veto tiver sido concedido ao administrador (diretor ou conselheiro) "eleito em separado" pelos credores, neste caso, basta que o administrador se manifeste favoravelmente ou contrário à prática do ato especificado no plano de recuperação judicial. Se for exercido o poder de veto, mas esta decisão não for cumprida pela sociedade, a recuperação poderá ser convolada em falência por descumprimento do plano aprovado.

Para CASTRO (2006, p. 207), o meio de recuperação previsto no inc. V do art. 50 da LREF deve ser interpretado do seguinte modo:

o poder de veto é concedido aos administradores, eleitos em separado, pe-
los credores. Assim, estes exercem direta e indiretamente o poder que
lhes concede a lei: por via direta, ao proporem que o plano contemple po-
der de veto em relação a determinadas matérias (art. $56, \S 3$, e por via
indireta, mediante o exercício do direito, pelos administradores, eleitos
em separado, por eles, credores. Frise-se, a propósito, a constante adoção
de mecanismos dessa natureza em acordos de acionistas. Ou seja: a exis-
tência de regras no sentido de que determinadas matérias somente são
aprovadas se positivo o voto de conselheiros (ou diretores, quando for o
caso), indicados por determinados acionistas.

Seguindo este argumento, para assegurar o exercício do direito de veto aos diretores eleitos pelos credores é necessário alterar-se o estatuto social, tanto para se estabelecer que determinadas matérias serão objeto de deliberação pela diretoria, quanto para se atribuir poder de veto a certos diretores (CASTRO, 2006, p. 207).

Esta solução, porque não elimina a obrigação da sociedade de cumprir o plano de recuperação sob pena de decretação de falência, apenas onera a devedora, porquanto a finalidade pretendida pela lei também é atingida sem qualquer modificação estatutária. 
É necessário acrescentar, por fim, que CASTRO (2006, p. 208) tem razão quando afirma que tanto a eleição de administradores pelos credores quanto o poder de veto são transitórios, de modo que, verificado o cumprimento de todas as obrigações que se vencerem no prazo de dois anos, a recuperação judicial será encerrada (arts. 61 e 63 da LREF), e os direitos concedidos aos credores no plano de recuperação deixam de ser exigíveis. Se o encerramento da recuperação acarreta a exoneração do administrador judicial, não há razão para manter-se o direito do credor de indicar administrador.

Em outras palavras: caso o devedor cumpra todas as obrigações que se venceram no prazo de dois anos e tenha a recuperação encerrada, se não tiverem sido quitados todos os débitos sujeitos à recuperação, permanecerá sua obrigação de pagar as dívidas na forma ajustada no plano, obrigação esta cujo inadimplemento é causa de decretação da falência (art. 94, inc. III, alínea "g”, da LREF); entretanto, extintos estarão os direitos do credor de indicar administrador, bem como o poder de veto, razão pela qual a "violação" de qualquer desses "direitos" dos credores, após o encerramento da recuperação, não será causa de decretação da falência.

\subsection{Administração compartilhada}

O inciso XIV do art. 50 da LREF prevê, como um dos meios de recuperação judicial, a administração compartilhada. Trata-se, como alerta SIMIONATO (2008, p. 149), de mera consequência dos meios de recuperação estabelecidos nos incisos IV (substituição total ou parcial dos administradores) e V (direito dos credores elegerem - na realidade o direito é de indicar - administradores, bem como atribuição de poder de veto de certas matérias).

Este meio de recuperação judicial, contudo, é mais amplo que a simples concessão aos credores do direito de "eleger" administradores em separado, porquanto a administração poderá vir a ser compartilhada não apenas com os credores, mas também com trabalhadores (LOBO, 2007, p. 146).

SZTAJN (2007, p. 245), entretanto, critica este meio de recuperação judicial: 
a concepção de administração compartilhada, que surge pela inclusão de minoritários na tomada de decisões nas anônimas, foi formulada para acalmar demandas, portanto desenhada para outro campo de embates. Maioria e minoria nas sociedades disputam o poder o que não é o caso na recuperação da empresa em crise, daí entender-se ser inadequada para essa situação. Imaginando que cada uma das partes elege administrador(es) em igual número e que as decisões administrativas sejam sempre tomadas por consenso, unanimidade, o custo de transação aumenta, uma vez que os procedimentos serão mais lentos. A eficácia de uma tal medida é questionável, se é que existe, no campo da recuperação de empresas em crise.

De todo modo, tudo o que se afirmou nos comentários aos meios de recuperação judicial estabelecidos nos incisos IV e V do art. 50 da LREF também se aplica à administração compartilhada, em especial quando à possibilidade de a recuperação judicial ser convolada em falência na hipótese de o devedor não cumprir as obrigações assumidas no plano de recuperação, entre elas a obrigação de compartilhar a administração da sociedade.

Acrescente-se, apenas, que, para COELHO (2008, p. 140), a administração compartilhada normalmente se verifica mediante a indicação, pelos credores, de um ou alguns dos administradores; entretanto, existem outras formas de compartilhamento, tal como a obrigatoriedade de se consultar determinado grupo para que determinado ato possa vir a ser praticado.

\section{5. $O$ afastamento do devedor previsto no plano de recuperação}

O plano de recuperação judicial poderá contemplar, como meio de recuperação, o afastamento do próprio devedor, hipótese na qual afastada da gestão da empresa devedora será a própria sociedade empresária - quer seja limitada quer seja sociedade por ações -, e os credores elegerão, na forma do art. 65 da LREF, o gestor judicial que conduzirá a atividade empresarial de fora da estrutura societária do devedor.

Daí que a implementação desse meio de recuperação judicial independe da prática de qualquer ato societário: a nomeação do gestor judicial se implementará mediante decisão judicial, realização de assembleia de credores (LREF, art. 65), e a posse do gestor judicial. 
Repita-se: no caso de afastamento do devedor e nomeação de gestor judicial, os órgãos societários permanecem regularmente constituídos, de modo que o gestor judicial, sem ingressar na pessoa jurídica (ou seja, sem substituir seus diretores, conselheiros ou acionistas), passa a administrar o patrimônio do devedor, mas não assume a condução do processo de recuperação judicial, a qual permanece sob a responsabilidade exclusiva do devedor.

Porque a nomeação do gestor judicial importa no afastamento da própria pessoa jurídica, é muito raro que o próprio devedor inclua no plano de recuperação (que somente a ele compete a elaboração, e eventuais alterações dependem de sua expressa aprovação) sua substituição pelo gestor judicial, de modo que somente em casos excepcionais é que o plano de recuperação judicial contemplará a nomeação do gestor judicial.

\subsubsection{A recuperação judicial de Bombril Holding S.A.}

Um caso excepcional em que o próprio devedor incluiu no plano seu afastamento e a nomeação de gestor judicial ocorreu no processo de recuperação judicial da Bombril Holding S.A., companhia aberta que em 7.11.2005 requereu sua recuperação perante a $2^{\mathrm{a}}$ Vara de Falências e de Recuperações Judiciais da Comarca de São Paulo (processo $\left.\mathrm{n}^{\mathrm{o}} 000.05 .123223-8\right)$.

Ao apresentar seu plano de recuperação, a Bombril Holding, com fundamento no art. 64, inc. VI, da LREF, pediu fosse transferida "a administração da devedora a um Gestor Judicial", que deveria ser eleito em assembleia geral de credores. E justificou seu afastamento da gestão da empresa porque sua controladora, a Cirio Finanziaria S.p.A., era companhia italiana que se encontrava em regime de Administração Extraordinária ${ }^{174}$.

\footnotetext{
${ }^{174} \mathrm{Na}$ manifestação em que apresentou judicialmente o plano de recuperação que seria submetido à aprovação dos credores, a devedora Bombril Holding expressamente consignou: "[...] a Cirio Finanziaria S.p.A. encontra-se em regime de Administração Extraordinária na Itália. E, no momento, é administrada por 3 (três) Comissários Extraordinários nomeados pelo Ministério da Atividade Produtiva daquele país. O objetivo precípuo desses administradores é liquidar os ativos para pagamento da coletividade dos credores [...] Portanto, em razão dessa situação, a supte, com a concordância da Cirio Finanziaria, pondera que seria conveniente, para dar maior transparência aos credores, transferir, desde logo, a administração da devedora a um Gestor Judicial, nos termos do art. 65 da Lei de Falências. Ressalvando, desde logo, que não estão presentes quaisquer dos fatos relacionados nos incisos I a V do Art. 64 do Estatuto Falimentar. Entretanto, o Plano de Recuperação (que é elaborado pela devedora) pode prever esse afastamento, conforme dispõe o inciso VI dessa norma legal [...] cumpre ressalvar que o afastamento da devedora somente ocorrerá com a realização da assembleia geral de credores a ser convocada por V. Exa. e, ainda, somente na hipótese de tal assembleia apro-
} 
Ressaltou, contudo, que: (a) o afastamento da devedora somente se daria com a aprovação, na assembleia geral de credores, da nomeação do gestor judicial, pois, caso contrário, "a devedora permanecerá na condução de suas atividades"; e (b) a administração da Bombril Holding competiria ao gestor judicial "até a esperada homologação judicial do Plano de Recuperação."

$\mathrm{Na}$ assembleia geral, os credores aprovaram um dos indicados "para o cargo de Gestor Judicial da Bombril Holding, o que deverá assumir integralmente a administração das atividades da devedora, inclusive representando-a nas assembléias gerais de acionistas de suas controladas, até a homologação judicial do Plano de Recuperação...”, tendo o gestor judicial firmado termo de compromisso em 11.4.2006.

A nomeação do gestor judicial neste caso chama a atenção por alguns aspectos. O primeiro deles, por óbvio, é o fato de a própria devedora, de maneira voluntária, ter incluído, no plano de recuperação judicial, seu afastamento e a nomeação de gestor judicial.

Por outro lado, por se tratar de holding, a devedora não tem atividade econômica de produção e distribuição de bens, ou prestação de serviços, limitando-se seu objeto social à administração de participações societárias, de modo que a atuação do gestor judicial limitava-se, em princípio, à participação nas assembleias gerais das subsidiárias ou controladas $^{175}$.

Ademais, também deve ser destacada a circunstância de ter constado expressamente da ata da assembleia geral de credores que o gestor judicial assumiria a administração da empresa até a data da homologação do plano de recuperação (o que ocorreu em

\footnotetext{
var o afastamento da devedora, ora espontaneamente oferecido, com a consequente indicação do Gestor Judicial. Assim, não sendo aprovado tal afastamento pela assembleia geral de credores e/ou não sendo indicado o Gestor Judicial no conclave, em vista da não ocorrência de nenhuma das hipóteses previstas nos incisos do I a V do art. 64 da Lei de Falências, a devedora permanecerá na condução de suas atividades, como previsto no 'caput' do referido dispositivo legal."

175 É importante destacar que na ação de execução movida por Newco International Limited contra Bombril Holding S.A., Cirio Finanziaria S.p.A. e Crganotti \& Partners Capital Investment Brasil S.A. perante a $10^{\mathrm{a}}$ Vara Cível Central de São Paulo (processo no 000.02.071496-2) o direito de voto da ações de titularidade da Bombril Holding foi atribuído a administrador judicial, nomeado na forma do art. 719 do Código de Processo Civil, daí surgindo a discussão a respeito de quem deveria votar nas assembleias da subsidiárias: o gestor judicial eleito pelos credores ou o administrador judicial nomeado no processo de execução singular.
} 
29.5.2006 - art. 58 da LREF) e não até a data do encerramento da recuperação judicial (art. 61 da LREF).

Bem por isso é que, em vários "Instrumento Particular de Quitação" celebrados pela Bombril Holding em 28.7.2006 (ou seja, após a homologação do plano de recuperação, mas antes do encerramento do processo de recuperação judicial), a devedora não se fez representar pelo gestor judicial, mas pelos diretores eleitos na forma estabelecida pelos acionistas em seu Estatuto Social.

10.

O procedimento para o afastamento do devedor

A regra geral, como se viu, é a manutenção do devedor e de seus administradores na condução da atividade empresarial. Isso não obstante, constatada a ocorrência de qualquer uma das circunstâncias indicadas nos incisos do art. 64 da LREF, os administradores serão afastados e substituídos por outros eleitos na forma estabelecida no contrato ou no estatuto social, e se se tratar de afastamento do devedor, os credores elegerão o gestor judicial a quem se incumbirá a gestão do próprio devedor.

As hipóteses de afastamento, por outro lado, são numerus clausus, não podendo os administradores e o devedor ser afastados pela prática de atos diversos dos descritos na lei e, de igual modo, impõe-se a comprovação da subsunção da conduta do devedor em uma das hipóteses legais.

A comprovação da prática da conduta, ademais, deve ser feita respeitando-se, sempre, os princípios do contraditório e da ampla defesa, bem como a norma constitucional que outorga a todos, sem distinção, o direito de não ser privado de seus bens (o que inclui o direito de não ser privado da administração de seus bens), sem o devido processo legal (art. 5º incisos LIV e LV, da Constituição Federal) ${ }^{176 \_177 \_178 . ~}$

176 O TJSP, por sua Câmara Reservada à Falência e Recuperação, ao julgar o agravo de instrumento $n^{\circ}$
$0445366-51.2010 .8 .26 .0000$, relator Desembargador Elliot Akel, j. 01.03.2011, não chegou a apreciar a nuli-
dade da decisão que destitui o administrador ou o devedor, porque o recurso, neste aspecto, restou prejudica-
do. Entretanto, a declaração de voto apresentada pelo Desembargador Romeu Ricupero contém longa expla-
nação a respeito da necessidade ou não de contraditório relativa ao preenchimento da hipótese de afastamento
do devedor ou seus administradores, destacando-se o seguinte trecho: “[...] a LFR não prevê a oitiva prévia
dos credores, do Ministério Público e dos próprios devedores afastados. HUMBERTO LUCENA PEREIRA
FONSECA ensina, comentando o referido artigo 64 da LFR: 'A solução estipulada pela Lei foi a regra da 
manutenção da administração, exceto se configurada alguma das hipóteses previstas nos incisos do art. 64. O rol de exceções à regra da manutenção contempla situações cuja gravidade o legislador considerou suficiente para dispensar o debate acerca de virulência dos atos dos administradores e da capacidade destes para orientar a empresa em direção à superação da crise' (Comentários à Nova Lei de Falências e Recuperação de Empresas, coordenação de Osmar Brina Corrêa-Lima e Sérgio Mourão Corrêa Lima, Rio de Janeiro, Forense, 2010, p. 430). O mesmo autor sublinha, em outra passagem, que 'verificando-se a subsunção da situação do devedor ou de algum administrador a qualquer das hipóteses previstas na lei, o afastamento pode ser determinado pelo juiz, de ofício, ou a requerimento do administrador judicial, do Comitê de Credores, de credor, do Ministério Público ou de qualquer interessado' (obra citada, p. 432). GLADSTON MAMEDE professa o mesmo entendimento e de maneira enfática afirma: 'Não cuidou o legislador de regrar o procedimento que dá origem à decisão de afastamento do empresário ou administrador societário pela prática de qualquer dos atos inscritos no artigo 64 da Lei 11.101/05. Essa ausência de regramento cria um desafio em relação à iniciativa de medida. No entanto, da forma como escrito o texto do artigo 64, garantindo a permanência na condução da atividade empresarial, mas excepcionando hipóteses em que deverá haver o afastamento, parece-me forçoso reconhecer bastar a verificação de fato que corresponda a qualquer das previsões para que dele decorra, $e x$ officio ou a pedido do interessado, a decisão de destituição. Essa posição é reforçada pelo texto do parágrafo único do mesmo artigo 64, que fala categoricamente: verificada qualquer das hipóteses do caput deste artigo, o juiz destituirá o administrador. Destaque-se do período transcrito a frase o juiz destituirá o administrador, não se fala que o juiz deferirá a destituição do administrador, o que deixa claro que a medida pode ser tomada mesmo de ofício' (Direito Empresarial Brasileiro: Falência e Recuperação de Empresas, $3^{a}$ edição, São Paulo, Editora Atlas S/A, 2009, volume 4, p. 256). Não é essa, contudo, a lição de SÉRGIO CAMPINHO, que abordando a mesma matéria doutrina que 'verificada, após o devido contraditório e o exercício da ampla defesa, constitucionalmente garantidos, qualquer situação elencada como motivadora do afastamento em relação ao administrador da sociedade devedora, o juiz o destituirá, procedendo-se a sua substituição, conforme regra contida no ato constitutivo e, se omisso, conte as regras legais pertinentes' (Falência e Recuperação de Empresa, $2^{a}$ edição, Rio de Janeiro, Renovar, 2006, nº 86, p. 151). Na mesma direção o magistério de JULIO KAHAN MANDEL, destacando que 'o afastamento do administrador da condução dos negócios é medida extrema e deve ser adotado com toda a cautela possível e com respeito ao devido processo legal, ou seja, sempre se deve permitir ao administrador e aos proprietários da empresa que apresentem defesa' (Nova Lei de Falências e Recuperação de Empresas Anotada, São Paulo, Saraiva, 2005, p. 138). ALBERTO CAMIÑA MOREIRA, sempre na mesma direção, também enfatiza que, 'de ordinário, o devedor 'permanece na condução da atividade empresarial' (art. 64). Se incidir, porém, numa das hipóteses arroladas no incisos desse artigo, será afastado pelo juiz, após ser regularmente ouvido; para esse fim, deve-se obedecer ao princípio do contraditório' (Direito Falimentar e a Nova Lei de Falências e Recuperação de Empresas, coordenação de Luiz Fernando Valente de Paiva, São Paulo, Quartier Latin, 2005, p. 263-264). Embora sem se manifestar sobre o devido processo legal, FREDERICO A. MONTE SIMINONATO é radicalmente contrário ao afastamento do devedor e dos administradores na recuperação judicial (Tratado de Direito Falimentar, Rio de Janeiro, Forense, 2008, n 103, p. 192). Observe-se que, mesmo quando a lei especial, expressamente, admitiu a destituição de ofício do Administrador Judicial ou de quaisquer dos membros do Comitê de Credores (caput do art. 31 da Lei $\left.\mathrm{n}^{\circ} 11.101 / 2005\right)$, HAROLDO MALHEIROS DUCLERC VERÇOSA alertou que 'mais uma vez nota-se a ausência do direito de defesa, por parte da pessoa acusada, de qualquer dos fatos previstos na norma ora examinada. Como a decisão do juiz deverá ser devidamente fundamentada, a fim de não se caracterizar como um ato arbitrário, caberá o direito de defesa à pessoa assim destituída' (Comentários à Lei de Recuperação de Empresas e Falência, coordenação de Francisco Satiro de Souza Junior e Antônio Sérgio A. de Moraes Pitombo, $2^{a}$ edição, São Paulo, Editora Revista dos Tribunais, 2007, p. 184). Viva a controvérsia na doutrina, esta última posição, exigindo a defesa do interessado, parece-me mais consetânea com a tradição do direito brasileiro, que assegura constitucionalmente os direitos ao devido processo legal e ao contraditório a quem é acusado de praticar ato capaz de gerar sanção como é a destituição de sócio da administração da sua empresa. Assim, em princípio, seria o caso, segundo o meu ponto de vista, de se dar provimento ao recurso, para afastar a destituição do agravante, enquanto não lhe fosse assegurado o direito de ser ouvido sobre as acusações imputadas pelo administrador judicial.”

${ }^{177}$ No mesmo sentido, assegurando ao administrador e/ou ao devedor acusados da prática de uma das condutas descritas nos incisos do art. 64 da LREF o direito à ampla defesa e o contraditório, também já decidiu o TJPR, Agravo de Instrumento n ${ }^{\circ}$ 981403-7, 17 Câmara Cível, Relator Desembargador Mário Helton Jorge, j. 27.05.2013, v.u.

${ }^{178}$ Em sentido contrário decidiu o TJSP, Agravo de Instrumento no 0053075-37.2012.8.26.0000, Relator Desembargador Tasso Duarte de Melo, j. 16.10.2012, v.u., pois após firmar que, no caso, o recorrente "teve, portanto, diversas oportunidades de exercer o contraditório e a ampla defesa", acrescentou que "não há de- 
Daí que, como o parágrafo primeiro do art. 64 da LREF apenas estabelece que “verificada qualquer das hipóteses do caput deste artigo, o juiz destituirá...”, qualquer interessado (o que inclui, por óbvio, os credores, os membros do comitê de credores, o administrador judicial, os representantes do Ministério Público, etc.) pode pedir ao juiz o afastamento do devedor ou de seus administradores, mas para tanto deverá expor o fato se subsume em uma das hipóteses legais, indicando que elementos comprobatórios dispõe ${ }^{179}$.

Antes de acolher o pedido, o juiz deverá facultar ao acusado a possibilidade de exercer seu direito de defesa, produzindo todas as provas necessárias à demonstração de que não se justifica seu afastamento. Somente após a produção das provas requeridas pelas partes é que o juiz poderá acolher, ou não, o pedido de destituição dos administradores ${ }^{180}$ ou do devedor, sendo que no primeiro caso o devedor será intimado para escolher novos dirigentes, nos termos de seus atos constitutivos, enquanto no segundo caso (afastamento do devedor), o juiz convocará assembleia geral de credores para deliberação a respeito de quem será nomeado gestor judicial.

\section{O procedimento para a eleição do gestor judicial: a assembleia geral de credores e a nomeação pelo juiz}

Constatada a prática de qualquer uma das condutas descritas nos incisos do art. 64 da LREF, o juiz, respeitada a ampla defesa e o contraditório, deverá, até mesmo de ofício, afastar o devedor (ou seja, a sociedade empresária limitada e a sociedade empresária

terminação legal no sentido de que o gestor deve ser intimado para se manifestar antes de sua destituição, o que também afasta a alegação de cerceamento de defesa."

179 Nesse sentido decidiu o TJSP, Agravo de Instrumento $\mathrm{n}^{\circ}$ 653.659-4/9-00, Relator Desembargador Lino Machado, j. 27.10.2009, v.u.: “o art. 64 da NLF não estipula prazo para que os administradores possam ser destituídos. Tampouco limita a legitimidade ativa dos interessados em suscitar pronunciamento judicial a respeito do tema, o que faz a sócia minoritária ter legitimidade para tanto, legitimada que está a postular até mesmo a falência da sociedade (art. 97, caput, III, da NLF). A respeito, lecionada Gladstim Mamede que 'o juiz destituirá o administrador, seja a requerimento de interessado - administrador judicial, comitê de credores, Ministério Público, qualquer credor, trabalhador, e, até, sócio, ou mesmo de ofício' (Falência e Recuperação de Empresas - São Paulo: Atlas, 2006, pág. 292).”

${ }^{180}$ O TJSP, no Agravo de Instrumento nº 0470498-13.2010.8.26.0000, Relator Desembargador Lino Machado, j. 21.6.2011, v.u., decidiu que o administrador afastado pode continuar a receber remuneração: "Se é fato que a remuneração pro labore está vinculada à prestação de serviços pelos administradores à empresa que conduziam, a suspensão de tais serviços, por imposição judicial, não acarreta, automaticamente, a impossibilidade de continuarem a receber o valor necessário à sua sobrevivência, se isso não afeta o cumprimento do plano de recuperação judicial aprovado e se não há oposição dos credores em assembleia geral ou mesmo por meio do seu comitê." 
por ações) e, nos termos do art. 65, “convocará a assembleia geral de credores para deliberar sobre o nome do gestor judicial que assumirá a administração das atividades do devedor."

A assembleia geral de credores, segundo CAMPINHO (2008, p. 77), consiste na reunião de credores (sujeitos à falência e à recuperação judicial), divididos em classes de acordo com a natureza de seus respectivos créditos, com a finalidade de deliberar as matérias especificadas em lei ou outras que sejam de seus interesses.

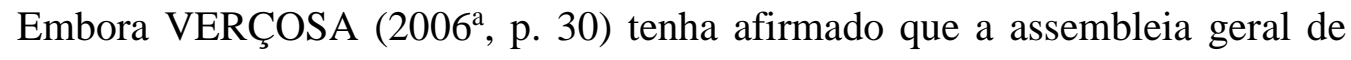
credores é órgão obrigatório que funcionará durante todo o processo de recuperação judicial, a realidade, porém, é que, como esclarece FRANÇA (2007, p. 189), a assembleia geral é um órgão de funcionamento facultativo, porquanto, na recuperação judicial, se nenhum credor se opuser ao plano de recuperação apresentado pelo devedor, é possível que a assembleia geral de credores jamais seja convocada.

Na recuperação judicial, a assembleia geral tem por finalidade, precipuamente, deliberar a respeito do plano de recuperação judicial, a constituição do comitê de credores e sua composição, a desistência da recuperação judicial eventualmente apresentada pelo devedor, a eleição do gestor judicial, bem como qualquer outra matéria que afete os interesses dos credores ${ }^{181}$.

Para FRANÇA (2007, p. 189), a assembleia geral é órgão hierarquicamente superior a dois outros órgãos da recuperação, quais sejam, o comitê de credores e o gestor judicial, uma vez que é na assembleia que se delibera a respeito da constituição e composição destes outros órgãos. Entretanto, prossegue o autor, a assembleia geral de credores não predomina sobre o administrador judicial, que está subordinado exclusivamente ao juiz que o nomeou, tanto que o Presidente da República vetou a alínea "c" do inc. I do art. 35 da LREF, que atribuía à assembleia geral competência para substituir o administrador judicial.

\footnotetext{
${ }^{181}$ Art. 35. A assembleia geral de credores terá por atribuições deliberar sobre: I - na recuperação judicial: a) aprovação, rejeição ou modificação do plano de recuperação judicial apresentado pelo devedor; b) a constituição do Comitê de Credores, a escolha de seus membros e sua substituição; c) (VETADO); d) o pedido de desistência do devedor, nos termos do $\S 4^{\circ}$ do art. 52 desta Lei; e) o nome do gestor judicial, quando do afastamento do devedor; f) qualquer outra matéria que possa afetar os interesses dos credores.
} 
Destaque-se, ademais, que a LREF regula as formalidades que devem ser obedecidas na realização do conclave de credores, destacando-se:

(a) a competência, a publicidade, a forma, os prazos e os custos para sua convocação (art. $36)$;

(b) as formalidades para sua instalação e realização, tais como a designação do presidente, a escolha do secretário, o quórum de instalação, a assinatura da lista de presença, a necessidade de ser lavrada ata, e a possibilidade de o credor ser representado por mandatário e de o sindicado representar seus associados (art. 37);

(c) a apuração do valor do voto de cada um dos credores, bem como os critérios para a verificação dos credores que terão direito de voto (arts. 38, 39 e 43);

(d) a proibição de se deferir medida judicial suspendendo ou adiando a realização da assembleia geral de credores em razão da existência de discussão sobre a existência, valor ou classificação de créditos (art. 40);

(e) a classificação dos credores, em três classes distintas, para efeito de participação na assembleia geral cujo objeto seja deliberar sobre o plano de recuperação judicial ou sobre a nomeação dos membros que formarão o comitê de credores (arts. 41 e 44); e

(f) os quoruns de aprovação das matérias (arts. 42, 45 e 46, sendo que este último dispositivo incide apenas na falência, não na recuperação judicial).

De todas essas matérias reguladas pela LREF quanto às formalidades para a realização da assembleia geral de credores, duas merecem especial destaque.

A primeira é a norma constante do art. 40 da LREF que dispõe: "não será deferido provimento liminar, de caráter cautelar ou antecipatório dos efeitos da tutela, para a suspensão ou adiamento da assembleia geral de credores em razão de pendência de discussão acerca da existência, da quantificação ou da classificação de créditos." 
Para BEZERRA FILHO (2007, p. 127), SIMIONATO (2008, p. 105) e BERTASI (2007, p. 161) este artigo flagrantemente viola o inciso XXXV do art. $5^{\circ}$ da Constituição Federal, segundo o qual "a lei não excluirá da apreciação do Poder Judiciário lesão ou ameaça a direito.”

Entretanto, para FRANÇA (2007, p. 189) esta norma não é inconstitucional, pois a LREF assegura a participação dos credores no conclave, de modo que "se o juiz deixa de reconhecer um crédito, ou quantifica-o abaixo do valor pretendido pelo credor, ou ordena a sua classificação em outra classe, o credor poderá agravar”, hipótese na qual o relator do recurso poderá atribuir-lhe suspensivo, nos termos do parágrafo único do art. 17, e, assim, assegurar a participação do credor no conclave.

A outra matéria que merece destaque diz respeito aos quoruns para aprovação das matérias submetidas à deliberação dos credores, porquanto a LREF estabelece, para a recuperação judicial, dois quoruns distintos, a saber:

(a) quorum para aprovação do plano de recuperação judicial: na votação a respeito do plano de recuperação os credores são separados em três classes distintas (art. 41, LREF): (a) trabalhadores e créditos decorrentes de acidentes de trabalho; (b) créditos com garantia real; e (c) créditos quirografários, com privilégio especial, com privilégio geral ou subordinados. Para que o plano seja aprovado, a LREF estabelece o seguinte quorum: maioria dos credores, votando "por cabeça", nas três classes, e, cumulativamente, na classe dos créditos com garantia real e na classe dos créditos quirografários, com privilégio e subordinados, créditos que correspondam a mais da metade do passivo de cada uma dessas classes;

(b) quorum para aprovação de quaisquer outras matérias, o que inclui a eleição do gestor judicial: credores que representem mais da metade do valor dos créditos presentes na assembleia geral.

Tratando-se de assembleia geral convocada para eleger o gestor judicial que administrará a empresa do devedor afastado, qualquer interessado poderá indicar candidato cujo nome será submetido à deliberação assemblear, indicação essa que deverá ser acompanhada de elementos comprobatórios da idoneidade e competência do candidato, de modo 
a permitir que não apenas os credores, mas também o devedor afastado, apurem se ele preenche os requisitos necessários ao exercício da função atribuída a esse órgão da recuperação judicial.

Eleito pelos credores representando a maioria do valor dos créditos presentes no conclave, o gestor judicial será nomeado pelo juiz, a quem compete fazer novo exame do preenchimento dos requisitos legais para a assunção desse órgão da recuperação, auxiliar do Poder Judiciário. Em consequência, se a pessoa eleita pelos credores estiver impedida, o juiz pode, fundamentadamente e de ofício, recusar-se a nomeá-lo e determinar a convocação de novo conclave para eleição de substituto.

Esclareça-se, porém, que, competindo a escolha do gestor aos credores reunidos em assembleia geral, o juiz somente pode se recusar a nomear a pessoa eleita na hipótese dela estar impedida, aplicando-se para o exame judicial as regras relativas ao impedimento ao exercício do cargo de administrador judicial (LREF, arts. 65 e 21), ou seja, deverá ser profissional idôneo ${ }^{182}$, como será melhor examinado a seguir.

Neste caso, ou seja, se o juiz recusar-se a nomear a pessoa eleita, segundo dispõe o parágrafo $2^{\circ}$ do art. 65 da LREF, “o juiz convocará, no prazo de 72 (setenta e duas) horas, contado da recusa ou da declaração do impedimento nos autos, nova assembleia geral, aplicado o disposto no $\S 1^{\circ}$ deste artigo."

Deste dispositivo legal decorre que serão realizadas tantas assembleias gerais de credores quantas se façam necessárias para eleger-se o gestor judicial que preencha todos os requisitos legais, não esteja impedido, nem se recuse a assumir esse órgão da recuperação judicial. A recusa ou impedimento do gestor eleito, desse modo, não tem como consequência transferir ao juiz poder para nomear o gestor substituto.

\footnotetext{
182 Além de idoneidade, a LREF estabelece outros requisitos para que o profissional possa ser eleito e nomeado gestor judicial, os quais serão objeto de exame específico em outra parte dessa dissertação: (a) está impedido quem, nos últimos cinco anos, tiver exercido cargo de administrador judicial, gestor judicial, ou integrado comitê de credores, e foi destituído, não prestou contas, ou as teve rejeitadas; (b) está impedido "quem tiver relação de parentesco ou afinidade até o $3^{\circ}$ (terceiro) grau com o devedor, seus administradores, controladores ou representantes legais ou deles for amigo, inimigo ou dependente" (art. 30, § $1^{\circ}$ ); e (c) está impedido quem pratica um dos atos que justifica o afastamento do devedor ou seus administradores.
} 
Por outro lado, se o juiz pode, fundamentadamente, recusar-se a nomear gestor a pessoa eleita pelos credores por entender faltar idoneidade ao profissional, após a nomeação e posse, o juiz também poderá destituí-lo, caso se constate a inidoneidade. Nesta hipótese, porém, porque a pessoa eleita foi nomeada e tomou posse, a destituição somente poderá ocorrer (fundamentadamente) após assegurar-se ao interessado (ou seja, ao gestor judicial e aos credores que o elegeu) o contraditório e o exercício do direito de defesa constitucionalmente assegurados.

Acrescente-se, ademais, que assim como pode ser destituído pelo juiz, o gestor judicial também poderá ser substituído. Para tanto, a requerimento de qualquer interessado, o juiz deverá convocar nova assembleia de credores para deliberar sobre a manutenção ou a substituição do gestor judicial, hipótese na qual novo deverá ser eleito no mesmo conclave.

Por fim, assim como o juiz pode se recusar a nomear o gestor eleito, este último também pode, imotivadamente, recusar-se a aceitar o encargo ${ }^{183}$, caso em que nova assembleia de credores será convocada pelo juiz.

\section{O perfil do gestor judicial}

A parte final do caput do art. 65 da LREF estabelece que ao gestor judicial aplicam-se, no que couber, as normas relativas aos deveres, impedimentos e remuneração do administrador judicial. Dessa norma decorre que ao gestor judicial incidem as mesmas regras que fixam os requisitos que devem ser preenchidos para que determinada pessoa possa ser nomeada administrador judicial.

Assim é que o art. 21 da LREF exige que o administrador judicial seja profissional idôneo, de preferência advogado, economista, administrador de empresas, contador ou pessoa jurídica especializada, na qual hipótese deve ser declarado quem será o profissional diretamente responsável pelo exercício da função, presentando a pessoa jurídica. Tratandose de gestor judicial o requisito deve ser o mesmo: o profissional deve ser idôneo.

\footnotetext{
${ }^{183}$ A hipótese de recusa da pessoa eleita, embora possível, é de rara ocorrência, porquanto dificilmente algum credor indicará um nome à deliberação assemblear sem antes obter a confirmação do "candidato" de que aceitará assumir a função.
} 
A exigência de que, se se tratar de pessoa natural, deva o profissional ser advogado, economista, administrador de empresas ou contador não é vinculativa, quer para a nomeação de administrador judicial, quer para a eleição de gestor judicial, visto que esta relação é meramente exemplificativamente, não taxativa. O que se exige é a idoneidade do profissional e que ele tenha experiência e capacidade técnica necessárias à administração da empresa do devedor afastado, de modo que, em tese, até mesmo pessoa sem curso superior poderá vir a ser eleita gestor judicial.

Por outro lado, também de modo similar ao requisito para a nomeação de administrador judicial, uma pessoa jurídica poderá ser eleita para exercer a função de gestor judicial, caso em que deverá ser indicada a pessoa natural que, em nome da jurídica, atuará diretamente gerindo a empresa do devedor afastado.

Não se ignora, por outro lado, a existência de deliberações assembleares tomadas em processos de recuperação judicial onde foram eleitas mais de uma pessoa para o cargo de gestor judicial, formando assim um comitê gestor ${ }^{184}$. Essa, porém, não parece ser a melhor solução para a condução dos negócios de devedor afastado.

Isto porque, ainda que se trate de recuperação judicial de grande empresa, ou de devedor que exerça atividade especializada, cuja condução requeira profissional com conhecimento e experiência específicos, em virtude das dificuldades que podem decorrer da nomeação de mais de uma pessoa para assumir a função (tais como, exemplificativamente, a divisão da função de cada um dos integrantes do comitê gestor e a responsabilidade atribuída a cada um de seus membros), a melhor alternativa seria a eleição de pessoa jurídica especializada, que certamente contará profissionais das mais diversas áreas do conhecimento, aptas a conduzir a empresa do devedor afastado.

A pessoa natural ou jurídica que, nos últimos cinco anos, tiver exercido cargo de administrador judicial, ou integrado comitê de credores, em processo de falência ou de recuperação judicial, e foi destituída, não prestou contas, ou teve as contas rejeitadas está

${ }^{184}$ Confira-se: TJSP, Agravo de Instrumento ${ }^{\circ}$ 0445366-51.2010.8.26.0000, Câmara Reservada à Falência e Recuperação, j. 01.03.2011, v.u., relator Desembargador Elliot Akel. 
impedida de ser nomeada novamente para o exercício dessa função, bem como para ser eleito gestor judicial, pois as regras relativas ao impedimento ao exercício do cargo de administrador judicial também se aplicam ao gestor.

Essa proibição, de acordo com TOMAZETTE (2011, p. 105), tem por finalidade assegurar a credibilidade do administrador (e também do gestor judicial), pois quem não exerceu adequadamente a função, pode novamente descumprir as funções. Proibição similar já constava da revogada legislação (arts. $60, \S 3^{\circ}$, III e 161, § $1^{\circ}$, IV), mas a novidade da LREF é a fixação do prazo de cinco anos, eliminando, assim, a possibilidade de o administrador judicial (e o gestor judicial) que descumpriu suas obrigações ficar indefinidamente impedido de exercer novamente a função.

O art. 30, $\S 1^{\circ}$, da LREF, por seu turno, dispõe que não poderá exercer a função de administrador judicial "quem tiver relação de parentesco ou afinidade até o $3^{\circ}$ (terceiro) grau com o devedor, seus administradores, controladores ou representantes legais ou deles for amigo, inimigo ou dependente" (art. 30, $\S 1^{\circ}$ ), restrição esta que, segundo TOMAZETTE (2011, p. 104), também se estende aos respectivos cônjuges. A questão que surge é se esse impedimento se aplicaria ou não à eleição do gestor judicial.

Na recuperação judicial de Arantes Alimentos Limitada (TJSP, Agravo de Instrumento no 0526210-85.2010.8.26.0000, Câmara Reservada à Falência e Recuperação, j. 17.05.2011, v.u., relator Desembargador Elliot Akel), além da eleição de um comitê gestor para administrar a empresa do devedor afastado, julgou-se se um dos integrantes do comitê gestor poderia ser justamente um sócio da pessoa jurídica afastada, tendo restado decidido:

sustenta ainda o agravante que 'não se observou o impedimento do dirigente da empresa anteriormente destituído por decisão judicial para ser nomeado para o cargo de gestor judicial', invocando o disposto no artigo 65 da LRF, segundo o qual ao Gestor Judicial se aplicam 'todas as normas sobre deveres, impedimentos e remuneração do administrador judicial', bem como o disposto no artigo 30 da mesma lei, ou seja, está impedido de exercer as funções de Administrador Judicial e Membro do Comitê de Credores aquele que foi destituído. O artigo 30, contendo uma proibição, deve ser interpretado restritivamente, isto é, não se aplica ao exercício das funções de Administrador Judicial e de membro do Comitê de Credores. Não há previsão de sua incidência em relação à nomeação de Gestor Judicial. Isso não significa que possa ser nomeado gestor judicial qualquer pessoa, como, por exemplo, aquele que houver sido condenado em sentença penal transitada em julgado por crime cometido em recupe- 
ração judicial ou falência anteriores ou por crime contra o patrimônio, a economia popular ou a ordem econômica previstos na legislação vigente (inciso I do art. 64 da LFR). Em outras palavras, tendo ocorrido uma destituição, não em falência ou recuperação outra, mas neste mesmo processo, o motivo de tal sanção deve ser sopesado. No caso dos autos, esse motivo foi sopesado pela própria AGC, que o considerou irrelevante...

Esta parece ser efetivamente a melhor solução, porquanto se os credores tinham ciência inequívoca de que um dos membros do comitê gestor é sócio da recuperanda e, mesmo assim, o elegeram, é porque consideraram ser ele fundamental para "viabilizar a superação da situação de crise econômico-financeira do devedor (LREF, art. 47).

Destaque-se, ainda, por óbvio, que não poderá ser eleito gestor judicial o candidato que incidir em qualquer das condutas previstas nos incisos do art. 64 da LREF, cuja prática importa no afastamento do devedor ou seus administradores: se o devedor foi afastado porque seu sócio controlador foi condenado criminalmente por sentença transitada em julgado, não pode ser nomeada gestor judicial a pessoa que se encontrar em idêntica situação.

Ademais, na hipótese de ser nomeada uma pessoa jurídica, as regras relativas aos impedimentos também devem ser aplicadas ao profissional indicado para conduzir o processo de falência ou de recuperação, de modo a impedir que, encoberta por uma pessoa jurídica, a pessoa natural impedida venha a, indiretamente, conduzir o processo falimentar ou administrar a empresa substituindo o devedor afastado.

É de se destacar, por fim, a existência de diferença fundamental entre o procedimento de nomeação do administrador e do gestor judicial: o primeiro é livremente escolhido pelo juiz, que também o substitui e o destitui a qualquer tempo, enquanto o segundo (gestor) é eleito pelos credores. Essa diferença no procedimento de escolha se mostra relevante quando se tem em conta que o gestor e o administrador judicial têm funções distintas: enquanto o último, no processo de recuperação, fundamentalmente fiscaliza o devedor, e, na falência, promove a realização do ativo para pagamento do passivo, o gestor judicial conduz a empresa do devedor afastado.

Essa diferenciação no processo de nomeação, porém, não se mostra acertada no caso de se deferir a continuação provisória das atividades do falido: como nessa última 
hipótese o que se busca é a maximização do valor da empresa (enquanto organização dos bens de produção), de modo a permitir o pagamento aos credores do maior valor possível, seria conveniente que a LREF contemplasse a possibilidade de os credores elegerem a pessoa responsável pela condução provisória da atividade do falido, quer essa função seja atribuída ao administrador judicial (como efetivamente dispõe a LREF), quer por qualquer outro órgão do processo falimentar, tal como ocorre em relação à escolha do gestor judicial. 
CAPÍTULO V - O EXERCÍCIO DA FUNÇÃO DO GESTOR JUDICIAL: SEUS DEVERES, RESPONSABILIDADES E REMUNERAÇÃo 


\section{CAPÍTULO V - O EXERCÍCIO DA FUNÇÃO DO GESTOR JUDICIAL: SEUS DEVERES, RESPONSABILIDADES E REMUNERAÇÃO}

\section{As funções do gestor judicial}

O art. 65 da LREF estabelece que se o devedor for afastado, o juiz convocará assembleia geral de credores para deliberar a respeito da escolha do gestor judicial, que "assumirá a administração das atividades do devedor".

Ocorre que, assim como se verifica em relação ao sentido do termo "devedor" empregado pelos arts. 64 e 65 da LREF, também há controvérsias doutrinárias quanto às funções que serão exercidas pelo gestor judicial.

De fato, para PACHECO (2007, p. 173), ao assumir as atividades do devedor, esse órgão da recuperação judicial não representa a empresa, que continuará a ser presentada por seus administradores escolhidos na forma de seus atos societários, ou nos termos do plano de recuperação aprovado pelos credores, presentantes esses que são mantidos na condução da atividade empresarial. Ao gestor judicial compete apenas orientar os administradores da sociedade empresária devedora.

No mesmo sentido, FRANCO e SZTAJN (2008, p. 250) anotam que, se se tratar de pessoa jurídica, o gestor judicial não presenta a sociedade devedora, que continua a ser gerida pelos administradores escolhidos pelos sócios na forma ajustada no contrato ou estatuto social.

SIMIONATO (2008, p. 108 e p. 195), por seu turno, destaca que esse órgão da recuperação judicial administra o devedor, mas somente pode praticar os atos de administração ordinária ${ }^{185}$ da empresa, pois os extraordinários dependem de autorização judicial, sob pena de sua responsabilidade pessoal do gestor.

\footnotetext{
185 Explicando o que é administração ordinária, SIMIONATO (2008, p. 195) destaca que "envolve somente a atividade necessária para cumprir o objeto social. Assim, caso o objeto social da sociedade for produção de
} 
Diversa, porém, é a posição de COELHO (2008, p. 176), para quem compete ao gestor judicial a direção da atividade econômica para a implementação do plano de recuperação, ou seja, a gestão das atividades empresariais, tais como assinatura de cheques, compra de matérias-primas e a contratação de prestadores de serviços. O gestor judicial, prossegue o autor, não presenta a sociedade empresária devedora nos atos relativos ao próprio processo de recuperação judicial, pois nesses atos quem presenta o devedor são os administradores eleitos na forma de seus atos societários.

Ora, partindo-se da interpretação de que devedor, para os fins do art. 65 da LREF, é a própria sociedade empresária devedora, tem-se que, na hipótese de seu afastamento, o gestor judicial, eleito pelos credores em assembleia geral, não ingressará na estrutura societária do devedor em recuperação judicial, pois a sociedade é integralmente afastada da condução da atividade econômica.

Assim é que a sociedade empresária permanece com todos os seus órgãos regularmente constituídos e em atividade: seus sócios e acionistas podem se reunir sempre que entenderem necessário; os conselheiros e administradores não são afastados ou substituídos, de modo que eventual conselho de administração e os membros da diretoria podem ser reunir e deliberar as matérias que entenderem necessárias.

E se os órgãos societários permanecem regularmente constituídos, o afastamento do devedor se implementa mediante a supressão de parte dos poderes que a sociedade empresária (titular de direitos e obrigações) exerce sobre a empresa ${ }^{186}$. Com efeito, operando-se o alijamento do devedor, o gestor judicial, sem ingressar na pessoa jurídica (ou seja, sem substituir seus diretores, conselheiros ou acionistas), assume a gestão

computadores, os atos de administração ordinária são aqueles que envolvem a compra e venda de materiais eletrônicos; peças de computadores; aplicativos; projetos de novos computadores, monitores etc. Jamais o gestor judicial poderá onerar, diretamente, via garantia real, aval e fiança, o patrimônio da sociedade; o gestor também não poderá aprovar plano de fusão, cisão, incorporação, alienação de bens do ativo da sociedade, alteração do objeto social; aumento de capital; e participação em grupos de sociedade (atos de administração extraordinária)".

186 De acordo com a celebrada distinção de ASQUINI (1996, p. 159), a empresa é um fenômeno poliédrico que, no aspecto jurídico, apresenta diversas faces ou perfis, a saber: (a) perfil subjetivo: o termo empresa, em determinadas normas legais é empregado para indicar o empresário, que conduz a atividade econômica; (b) perfil funcional: a palavra empresa é utilizada para indicar a atividade empresarial; (c) perfil patrimonial: a empresa como sinônimo de estabelecimento; e (d) perfil corporativo: a empresa como instituição. 
de todo o patrimônio da sociedade empresária devedora, podendo praticar todos os atos necessários à preservação da atividade produtiva.

Porque o gestor judicial não ingressa na sociedade empresária, ele não está vinculado a eventuais acordos de sócios ou acionistas e, de igual modo, não participa de possíveis atos societários que venham a ser implementados, tendentes a reestruturar a sociedade empresária devedora.

O gestor judicial também não assume, por outro lado, a condução do processo de recuperação judicial, a qual permanece sob a responsabilidade exclusiva do devedor, devidamente presentado por seus órgãos de administração constituídos na forma ajustada pelos sócios/acionistas em seu contrato/estatuto social.

A situação, embora não idêntica, é similar à do administrador judicial no processo de falência: a decretação da quebra promove "o afastamento do devedor de suas atividades" (LREF, art. 75), perdendo ele o direito de administrar seus bens e deles dispor (LREF, art. 103), gestão essa que passa a ser exercida pelo administrador judicial com vistas a "preservar e otimizar a utilização produtiva dos bens ativos e recursos produtivos, inclusive os intangíveis, da empresa" (LREF, art. 75). Isso não obstante, assegura-se ao falido a faculdade de "fiscalizar a administração da falência, requerer as providências necessárias para a conservação de seus direitos ou dos bens arrecadados, e intervir nos processos em que a massa falida seja parte interessada, requerendo o que for de direito e interpondo os recursos cabíveis" (LREF, art. 103, parágrafo único), hipótese na qual "as sociedades falidas serão representadas na falência por seus administradores ou liquidantes, os quais terão os mesmos direitos e, sob as penas da lei, ficarão sujeitos às obrigações que cabem ao falido" (LREF, art. 81, $\S 2^{\circ}$ ).

E a similaridade mostra-se ainda maior no caso de a sentença que decretar a quebra autorizar a "continuação provisória das atividades do falido", nos termos do art. 99, inc. XI, da $\mathrm{LREF}^{187}$, pois neste caso o administrador judicial (que não integra a estrutura

\footnotetext{
${ }^{187}$ Como destaca BALBINO (2009, p. 745), a continuação imediata e provisória das atividades do falido é instituto novo, porquanto a revogada Lei de Falências previa, no art. 74, a continuação do negócio a pedido do falido, "somente se estivessem arrecadados os bens e fosse a medida viável e conveniente, com proveito para os credores", o que se buscava, assim, era a satisfação dos interesses do credores. Na LREF, porém, o que prevalece é o interesse social: “A continuação provisória do negócio, autorizada pelo juiz de ofício, já na
} 
societária do falido, nem é um seu diretor nomeado na forma do contrato ou estatuto social), a quem a lei atribui a responsabilidade pela otimização produtiva dos bens e recursos da Massa Falida, é que conduzirá as atividades produtivas, gerindo a empresa. Mas a sociedade empresária falida atuará processualmente, requerendo as providências que entender necessárias, devidamente presentada na forma de seus atos societários.

Em outras palavras, no processo de falência, os bens arrecadados são geridos pelo administrador judicial que pratica todos os atos à conservação dos bens, e age processualmente como "Massa Falida", não se confundindo com a própria falida, que permanece atuando processualmente em seu próprio nome.

O mesmo se dá na hipótese de afastamento do devedor no processo de recuperação judicial: o gestor assume a administração das atividades e de todo o patrimônio da sociedade empresária devedora, o que não afasta o devedor de, atuando na forma estabelecida em seus atos societários comparecer no processo de recuperação judicial para formular requerimentos ao juiz, apresentar plano de recuperação judicial, discutir eventuais alterações no plano. Somente ao devedor, não ao gestor, compete praticar atos que digam respeito exclusivamente ao próprio processo judicial de recuperação, em especial a aceitação ou não das alterações ao plano de recuperação judicial eventualmente apresentadas pelos credores.

Faz-se necessário esclarecer, ainda, que, segundo dispõe o art. 66 da LREF, “após a distribuição do pedido de recuperação judicial, o devedor não poderá alienar ou onerar bens ou direitos de seu ativo permanente, salvo evidente utilidade reconhecida pelo juiz, depois de ouvido o comitê, com exceção daqueles previamente relacionados no plano de recuperação judicial."

Essa restrição à alienação e à oneração de bens evidentemente também se aplica ao gestor judicial: se o devedor, titular do patrimônio da empresa administrada pelo gestor judicial, não pode alienar ou gravar bens sem autorização judicial, após a oitiva do

sentença declaratória da falência, é medida concreta que permite a preservação da empresa. O dispositivo, mesmo contendo a ressalva do art. 109, deve ser interpretado segundo a função social da empresa, a ser mantida em atividade sempre que for possível, paradigma que prevalecerá sobre o interesse individual dos credores." 
comitê de credores ${ }^{188}$, de modo a preservar o interesse dos credores ${ }^{189}$, o gestor judicial também não poderá fazê-lo sem expressa anuência judicial, após a manifestação não apenas do comitê de credores, mas também do próprio devedor afastado da gestão da empresa, mas não desapropriado de seus bens e direitos.

\section{O exercício provisório das funções do gestor judicial: o administrador judicial}

Afastado o devedor, o juiz convocará assembleia geral de credores para deliberar a respeito da escolha do gestor judicial. Durante o período que mediar entre a destituição do devedor (= sociedade empresária limitada e sociedade por ações) e a eleição do gestor judicial em assembleia de credores, o encargo de gerir os negócios do devedor será atribuído ao administrador judicial, conforme expressamente estabelece o parágrafo $1^{\circ}$ do art. 65 da $\operatorname{LREF}^{190}$.

\footnotetext{
${ }^{188}$ Para LOBO (2007, p. 193), se o comitê de credores não tiver sido constituído, o juiz deverá colher a manifestação do administrador judicial (LREF, art. 22, inc. II, alínea a) e do Ministério Público, acrescentando que em casos excepcionais deverá (a) ser nomeado perito judicial para emitir parecer ou (b) colhida a opinião dos credores em assembleia geral. Esta, contudo, não parece ser a melhor interpretação dos dispositivo legal, pois se a manifestação do comitê de credores não é vinculante para a decisão judicial (ou seja, o juiz pode autorizar a prática de determinado ato que o comitê de credores rejeitou), não se justifica a demora e o gasto de recursos para a colheita da manifestação do administrador judicial, Ministério Público, Perito Judicial e credores reunidos em assembleia. Se os credores não se interessaram pela instalação do comitê de credores (que é órgão da recuperação judicial de funcionamento facultativo), a fundamentada decisão judicial independende da colheita de quaisquer manifestações, salvo do próprio devedor afastado no caso de ato ser praticado pelo gestor judicial.

${ }^{189}$ Comentando o art. 66 da LREF em relação à limitação aos poderes do devedor que administra a empresa em recuperação judicial, não tratando assim especificamente do gestor judicial, PACHECO (2007, p. 174) destaca que "não poderá o devedor alienar bens imóveis (venda, doação, dação em pagamento etc), hipotecar imóveis, aeronaves, navios, transferir estabelecimento, constituir direito real de garantia, penhor industrial ou agrícola”, acrescentando MUNHOZ (2007, P. 316) que ao limitar a necessidade de autorização judicial apenas aos bens que integram o ativo permanente do devedor, não outorgou necessária proteção aos credores: "na realidade econômica contemporânea a depender da natureza e da situação econômica da empresa, a alienação ou oneração de bens ou direitos que não integram o ativo permanente pode ser tão ou mais lesiva ao interesse dos credores do que a alienação ou oneração dos que o integram. A título ilustrativo, pode-se figurar a hipótese de uma empresa de serviços, cujo ativo permanente tem valor extremamemente reduzido, oferecer em penhor os seus recebíveis (direitos credtitórios) dos próximos 12 meses em garantia de um empréstimo concedido após a distribuição do pedido de recuperação. Obviamente, embora não tenha onerado bens do ativo permanente, um ato assim praticado pelo devedor deveria depender de autorização judicial, após ouvido o comitê de credores, por possuir um elevado potencial de ausa lesão aos credores anteriores; o risco de lesão aos credores decorrente dessa oneração de direito não integrante do ativo permanente seria muito superior, v.g., ao que decorreria da eventual oneração dos computadores da empresa."
}

190 Art. 65. $\S 1^{\circ}$ - O administrador judicial exercerá as funções de gestor enquanto a assembleia geral não deliberar sobre a escolha deste. 
De igual forma, o administrador judicial também assume provisoriamente a gestão da empresa em recuperação judicial no caso de o gestor eleito pelos credores em assembleia geral rejeitar a nomeação ou se estiver impedido (LREF, art. 65, $\S \S 1^{\circ}$ e $2^{\circ}$ ), bem como no caso de renúncia do gestor. Nestas hipóteses, o administrador judicial permanece na gestão do devedor até a data da nova eleição do gestor judicial.

Impõe-se, assim, o exame das principais questões relativas ao administrador judicial que, segundo RESTIFFE (2008, p. 328), "é órgão singular do juízo incumbido da fiscalização e, eventualmente, da execução dos atos e da administração do devedor”.

Para PENTEADO (2009, p. 166), “a terminologia única adotada pela lei - administrador judicial - para designar o profissional ou empresa especializada que atua tanto na falência, quanto na recuperação judicial, não está isenta de críticas", uma vez que no processo de falência o administrador judicial efetivamente "administra" a massa falida, pois arrecada, conserva e avalia os bens do falido ${ }^{191}$; representa a massa falida em Juízo ${ }^{192}$; cobra os créditos da Massa Falida ${ }^{193}$; etc. No processo de recuperação judicial, em contrapartida, o administrador judicial, em regra, não administra a empresa em crise, pois nos termos do art. 64 da LREF, durante o procedimento da recuperação judicial, o devedor ou seus administradores são mantidos na condução da atividade empresarial.

Daí que a denominação administrador judicial é equívoca e não indica com precisão as funções atribuídas a esse órgão do processo falimentar, as quais são muito díspares se se tratar de recuperação judicial ou de falência.

Exatamente porque a terminologia é equívoca, ela gerou, desnecessariamente, confusões em processos judiciais em que uma das partes está em recuperação judicial, pois

\footnotetext{
${ }^{191}$ LREF, Art. 22. Ao administrador judicial compete, sob a fiscalização do juiz e do Comitê, além de outros deveres que esta lei lhe impõe: III - na falência: f) arrecadar os bens e documentos do devedor e elaborar o auto de arrecadação, nos termos dos arts. 108 e 110 desta lei.

${ }^{192}$ LREF, Art. 22. Ao administrador judicial compete, sob a fiscalização do juiz e do Comitê, além de outros deveres que esta lei lhe impõe: III - na falência: n) representar a massa falida em juízo, contratando, se necessário, advogado, cujos honorários serão previamente ajustados e aprovados pelo Comitê de Credores.

${ }^{193}$ LREF, Art. 22. Ao administrador judicial compete, sob a fiscalização do juiz e do Comitê, além de outros deveres que esta lei lhe impõe: III - na falência: 1) praticar todos os atos conservatories de direitos e ações, diligenciar a cobrança de dívidas e dar a respective quitação.
} 
ao administrador judicial (órgão do processo falimentar que não administra a sociedade devedora) é frequentemente "atribuída" a representação da sociedade devedora.

Assim é que, por exemplo, em uma reclamação trabalhista, a União Federal sustentou a nulidade da citação da reclamada porque, estando ela em recuperação judicial, o ato não devia ter sido praticado na pessoa do administrador nomeado no contrato social, mas na pessoa do "administrador provisório", nos termos do art. 76 da LREF. O Tribunal Regional do Trabalho da $4^{\mathrm{a}}$ Região ${ }^{194}$ rejeitou a tese da União Federal, pois

não há de ser aplicado analogicamente o procedimento da citação previsto para os casos de falência na hipótese de recuperação judicial. Ocorre que o art. 64, caput, da Lei de $\mathrm{n}^{\circ}$ 11.101/2005 dispõe que, durante a recuperação judicial, o devedor ou seus administradores serão mantidos na administração dos seus bens, apesar de ficarem submetidos à fiscalização do Comitê de Credores, se houver, e do administrador judicial. Nesse sentido, o deferimento da recuperação judicial, por si só, não afasta o empresário da administração dos seus negócios. Embora fique sob a fiscalização do administrador provisório, ele continua detendo a representação judicial e extrajudicial da pessoa jurídica.

Criticando a nomenclatura empregada pela nova lei, KUGELMAS e PINTO (2009, p. 200) confirmam que frequentemente os administradores judiciais têm sido intimados para representar em juízo as sociedades em recuperação judicial, como se fossem os presentantes legais dos devedores, o que positivamente não são ${ }^{195}$.

Quanto aos critérios para a nomeação do administrador judicial, a revogada Lei de Falências (Decreto-Lei ${ }^{\circ} 7.661$, de 21.6.1945) dispunha em seus arts. 60 e 161, $\S 1^{\circ}$, inc. IV, que o comissário e o síndico seriam nomeados entre os maiores credores do falido ou do concordatário, "residente ou domiciliado no foro da falência (ou da concordata) de reconhecida idoneidade moral ou financeira."

A escolha de um credor para exercer o cargo seguia uma tradição do direito positivo brasileiro, pois, como anota ABRÃO (1999, p. 101), mesmo tendo havido varia-

\footnotetext{
${ }^{194}$ Recurso Ordinário no 0024800-55.2009.5.04.0741, cujo acórdão foi confirmado pelo Tribunal Superior do Trabalho no Agravo de Instrumento em Recurso de Revista no TST-AIRR-17991-07.2010.5.04.0000.

195 Fato ainda mais grave relata TAJRA (2009, p. 156): no exercício da função de administrador judicial no processo de recuperação judicial da Viação Aérea São Paulo (VASP), foi inúmeras vezes incluído no polo passivo de reclamações trabalhistas, provavelmente por equívocos ocorridos no momento do cadastramento dos processos nos sistemas informatizados da Justiça do Trabalho.
} 
ções nas diversas leis falimentares, a forma de escolha do administrador concursal sempre foi constante: "sua seleção entre os credores, o que é consentâneo com a concepção finalística que até hoje preside nossos diplomas legais, ou seja, liquidatária e solutória."

De fato, tanto o Código Comercial de $1850^{196}$, quanto nas sucessivas leis que regularam a matéria falimentar (Decreto $\mathrm{n}^{\mathrm{o}} 917$, de $14.10 .1890^{197}$, Decreto $\mathrm{n}^{\mathbf{0}} 859$, de 16.8.1902 $2^{198}$, Lei $n^{\mathrm{o}} 2.024$, de 17.12.1908 ${ }^{199}$, Decreto $\mathrm{n}^{\mathrm{o}} 5.746$, de 9.12.1929200) até o revogado Decreto-Lei $n^{\circ} 7.661$, de 21.6.1945 201 , a função de síndico (ou de comissário) sempre foi atribuída a um credor, uma vez que, como constou expressamente da Exposição de Motivos da revogada Lei de Falências, “o projeto revigora a função do síndico, ampliando-lhe os deveres e assegurando-lhe estabilidade. Tais medidas oneram o titular do cargo, mas o exercício deste constitui dever do comerciante em benefício do interesse coletivo do comércio, onde estão integrados os seus próprios interesses" (in VALVERDE, 1999, p. 264).

\footnotetext{
${ }^{196}$ Art. 809 - Na sentença da abertura da quebra, o Tribunal do Comércio ordenará que se ponham selos em todos os bens, livros e papéis do falido; designará um dos seus membros, dentre os Deputados comerciantes, para servir de juiz comissário ou de instrução do processo da quebra, e um dos oficiais da sua secretaria para servir de escrivão no mesmo processo: e nomeará dentre os credores, um ou mais que sirvam de Curadores fiscais provisórios, ou, não os havendo tais que possam convenientemente desempenhar este encargo, a outra pessoa ou pessoas que tenham a capacidade necessária. Os Curadores nomeados prestarão juramento nas mãos do Presidente; a quem incumbe expedir logo ao Juiz de Paz respectiva cópia autêntica da sentença da abertura da falência, com a participação dos Curadores fiscais nomeados, para proceder a aposição dos selos.

197 Art. 58, § único: Os síndicos e os membros da comissão fiscal serão credores ou não; eleitos, porém, por votação nominal que represente mais da metade do valor do passivo. Não havendo maioria absoluta, em segundo escrutínio, prevalecerá a relativa.

198 Art. 16. O juiz nomeará, além do síndico provisório, uma comissão fiscal composta de dois credores, tirados aquele e esta de duas listas organizadas na forma em seguida declarada: $\S 1^{\mathrm{o}}$ - de dois em dois anos, no mês de dezembro, as Justas Comerciais, onde as houver, organização uma lista de comerciantes do lugar, e a remeterão ao juiz do comércio, para servirem os alistados como síndicos nas falências que ocorrerem nos dois anos seguintes: (...) e) a designação recairá em comerciantes de fama ilibada, notoriamente abonados e que conheçam os negócios.
}

${ }^{199}$ Art. 64. Na sentença declaratória da falência, o juiz nomeará um ou três síndicos, conforme a importância da massa, para administrá-la, arrecadar bens e proceder aos trabalhos da verificação de créditos. $\S 1^{\circ}-$ Os síndicos serão escolhidos entre os credores do falido, de preferência os de maior quantia e idôneos, residentes e domiciliados no foro da falência.

${ }^{200}$ Art. 64. Na sentença declaratória da falência, o juiz nomeará um síndico para, sob sua imediata direção, administrar a massa, inventariar bens e proceder aos trabalhos de verificação de créditos. $\S 1^{\circ}$ - O síndico será escolhido entre os credores do falido, residentes e domiciliados no foro da falência, de reconhecida idoneidade moral e financeira. Não constando dos autos a relação de credores, o juiz poderá mandar notificar o devedor, se estiver presente, para apresentá-la em cartório dentro de duas horas e sob pena de prisão até trinta dias. Se não houver credores que aceitem o cargo, o juiz poderá nomear para síndico pessoas estranhas, idôneas e de boa fama.

${ }^{201}$ Art. 60: O síndico será escolhido entre os maiores credores do falido, residente ou domiciliado no foro da falência, de reconhecida idoneidade moral e financeira. 
Exatamente por essa razão é que a possibilidade de o juiz nomear um não credor para exercer a função de síndico ou comissário, após a sucessiva recusa de três credores do devedor (art. 60, § 2, do Decreto-Lei $n^{\circ} 7.661$, de 21.6.1945), foi criticada por FERREIRA (1966, p. 7): "Incompreende-se, em verdade, que se excluam os credores da sindicância, quando se trata de seus interesses. Isso, em teoria. Na prática, nem sempre é assim.”

A realidade, contudo, é que frequentemente os credores não aceitavam ser nomeados comissários ou síndicos, e a função acabava sendo exercida por profissionais (denominados dativos) de confiança dos Juízes. A LREF, adequando-se a essa realidade, rompeu com a tradição de nosso sistema jurídico e não exige que o administrador judicial seja um credor, mas também não proíbe que o seja $\mathrm{a}^{202}$. Houve, assim, uma profissionalização desse órgão da recuperação judicial e da falência o que, segundo PIMENTA (2006, p. 171), justifica-se porque

a função de administrador judicial pressupõe determinadas qualificações financeiras, técnicas e pessoais não necessariamente presentes entre os maiores credores do empresário. Por outro lado, o administrador judicial deve acompanhar com diligência e constância as atividades negociais do empresário em recuperação judicial, o que lhe demanda tempo, dedicação e atenção muitas vezes inexigíveis dos credores, estes legitimamente mais preocupados com suas próprias atividades.

Para ser nomeado administrador judicial exige-se apenas que o profissional seja idôneo, preferencialmente advogado, economista, administrador de empresas ou contador, ou pessoa jurídica especializada (art. 21, caput). Essa relação é meramente exemplificativa, não taxativa, sendo apenas uma "diretriz orientadora" (VERÇOSA, 2006 ${ }^{\mathrm{b}}$, p. 165), pois mesmo pessoas com formações diversas podem vir a ser nomeados pelos juízes. É o caso, por exemplo, dos engenheiros, que frequentemente exercem cargos de gestão nas

202 Nesse sentido, TOMAZETTE, 2011, p. 102. Entretanto, o TJSP, ao julgar a Apelação no 603.504-4/1-00 decidiu que, "levando-se em consideração as atribuições do administrador judicial, deve-se evitar a nomeação de um credor, e, sim, alguém desvinculado dos interesses envolvidos no processo concursal. Lembra-se que é o administrador judicial quem irá apreciar as habilitações e divergências quanto aos créditos relacionados pelo devedor, atividade que, se desenvolvida com isenção, evitará as impugnações direcionadas ao juiz; é ele que irá realizar o ativo, e assim por diante. É ele quem, na assembleia de credores, decidirá as questões que irão surgindo durante o ato." 
empresas $^{203}$ e, teoricamente, têm experiência e capacidade técnica para assumir a função de administrador judicial.

Acrescente-se apenas que embora a LREF, ao contrário do Decreto-Lei $\mathrm{n}^{\circ}$ 7.661/45, não exija expressamente que o profissional tenha idoneidade financeira, esse requisito também é exigido, pois o administrador judicial responde pelos prejuízos causados à massa falida, ao devedor ou aos credores por dolo ou culpa, prejuízos esses que podem ser vultosos se considerados os múltiplos interesses envolvidos (TOLEDO, 2007, p. 47).

O administrador judicial não precisa ser pessoa natural (assim como o comissário e o síndico não precisavam e, ao contrário, no mais das vezes, se não fossem dativos, não eram, pois os maiores credores em geral são sempre pessoas jurídicas, tanto fornecedores quanto instituições financeiras), autorizando a atual legislação que a função seja exercida por pessoa jurídica especializada, na qual hipótese será obrigatório declarar no termo de compromisso o nome do profissional responsável pela condução do processo de falência ou de recuperação judicial. Essa pessoa natural não poderá ser substituída sem autorização do juiz, pois como destaca VERÇOSA (2006 , p. 166), sua substituição pode causar prejuízos à condução dos processos falimentares.

Questão debatida em relação à nomeação do administrador judicial diz respeito à possibilidade de o juiz, considerando as características da recuperanda ou da falida, nomear conjuntamente mais de um profissional para exercer a função, possibilidade essa expressamente contida em algumas legislações anteriores ${ }^{204}$ quanto à escolha do síndico, mas que não é objeto de regulação pela LREF. Não se justifica, porém, a escolha de mais de um profissional para compor o órgão, pois essa nomeação conjunta importaria na distribuição das obrigações, na determinação das responsabilidades atribuídas a cada um deles, e possivelmente no aumento dos custos suportados pelo devedor ${ }^{205}$.

203 TOLEDO (2007, p. 48) informa em nota de rodapé que "em pesquisa realizada pela consultoria Heidrick \& Struggles, verificou-se que $49 \%$ dos presidentes das maiores empresas brasileiras são formados em engenharia (Quem são eles, Revista Exame, n. 835, de 2-2-2005, p. 20-26).”

${ }^{204}$ Código Comercial de 1850 (art. 809); Decreto n ${ }^{\circ}$ 917, de 14.10.1890 (art. 58, § único); e Lei no 2.024, de 17.12.1908 (art. 64, $\S 1^{\circ}$ ).

205 Em sentido contrário, no processo de falência da Imbra S.A., que se processa perante a $2^{\mathrm{a}}$ Vara de Falências e Recuperações Judiciais de São Paulo (processo n ${ }^{\circ}$ 0051798-45.2010.8.26.0100), duas pessoas 
Se a recuperação ou a falência forem complexas, o juiz deve escolher como administrador judicial uma pessoa jurídica especializada, pois ela certamente contará com profissionais de diversas áreas que atuarão em conjunto, sob a coordenação e supervisão da pessoa natural indicada no termo de compromisso, que responderá pessoalmente pelo cumprimento de todas as obrigações assumidas.

Oportuno destacar que o administrador judicial é pessoa de confiança do juiz, não dos credores ou dos demais interessados na recuperação ou na falência, pois é o magistrado quem o escolhe, o substitui e o destitui a qualquer tempo. Tanto assim é que, ao sancionar a LREF, a Presidência da República, por meio da Mensagem de Veto Presidencial $\mathrm{n}^{\text {o }}$ 59, de 9 de janeiro de 2005, vetou a alínea "c" do inc. I do art. 35 da LREF e a alínea "a" do inc. II do mesmo art. 35, que conferiam à assembleia geral de credores competência para destituir e eleger novo administrador judicial ${ }^{206}$.

Na recuperação judicial a atividade do administrador judicial, em regra, limitase à fiscalização do devedor e do cumprimento do plano aprovado pelos credores, não exercendo esse órgão a administração da empresa em crise, o que somente ocorre se o de-

naturais foram nomeadas, em conjunto, administradores judiciais, tendo sido atribuída a cada uma delas competência para, individualmente, praticar todo e qualquer ato que a LREF dispõe ser de responsabilidade desse órgão do processo falimentar.

206 "Mensagem de Veto Presidencial no 59, de 9 de janeiro de 2005, publicado no D.O.U. de 9.2.2005 Edição extra: "Razões de veto: As alíneas a e c atribuem à assembléia-geral de credores, dentro outras competências, a de deliberar sobre a substituição do administrador judicial e a indicação de seu substituto. Todavia tais disposições conflitam com o art. 52, que estabelece: 'Art. 52. Estando em termos a documentação exigida no art. 51 desta Lei, o juiz deferirá o processamento da recuperação judicial e, no mesmo ato: I - nomeará o administrador judicial, observado o disposto no art. 21 desta Lei; ..........' Verificase o conflito, também, no confronto entre esses dispositivos e o parágrafo único do art. 23, que dispõe: 'Parágrafo único. Decorrido o prazo do caput deste artigo, o juiz destituirá o administrador judicial e nomeará substituto para elaborar relatórios ou organizar as contas, explicitando as responsabilidades de seu antecessor.' Ao que parece, houve um equívoco do legislador ao mencionar o 'administrador judicial', parecendo que pretendeu se referir ao 'gestor judicial', uma vez que, ao prever a convocação de assembléiageral de credores para deliberar sobre nomes, o projeto refere-se a este último, como se atesta da leitura do art. 65, verbis: 'Art. 65. Quando do afastamento do devedor, nas hipóteses previstas no art. 64 desta Lei, o juiz convocará a assembléia-geral de credores para deliberar sobre o nome do gestor judicial que assumirá a administração das atividades do devedor, aplicando-se-lhe, no que couber, todas as normas sobre deveres, impedimentos e remuneração do administrador judicial.' Há, portanto, no texto legal, um equívoco que merece ser sanado, elidindo-se a possibilidade de a lei vir a atribuir competências idênticas à assembléiageral de credores e ao juiz da recuperação judicial ou da falência, o que ensejaria a inaplicabilidade do dispositivo, com inequívocos prejuízos para a sociedade, que almeja a celeridade do processo, e para o próprio Governo Federal, que tem adotado ações que possibilitem alcançar esse desiderato. Finalmente, impõe-se registrar que o veto afastará, de plano, a possibilidade de que seja nomeada para o encargo pessoa que não seja da confiança do juízo." 
vedor ou seus administradores forem afastados da gestão pela prática de um dos atos descritos nos incisos do art. 64 da LREF.

Neste caso, como informa PENTEADO (2009, p. 161),

a substituição atenderá também à regra geral peculiar ao direito societário, ou seja, deverá observar, em primeiro lugar, o que estiver previsto nos respectivos atos constitutivos da sociedade empresária, ou, excepcionalmente, o que dispuser o Plano (art. 64, § único). Somente à mingua de solução segundo essas fórmulas é que cabe à Assembleia Geral de Credores deliberar sobre o nome do gestor judicial (arts. 35, inc. I, alínea e, e $65)$.

Durante o período que mediar entre a destituição do devedor ou seus administradores e a eleição do gestor judicial pela assembleia geral de credores é que o administrador judicial efetivamente administrará a empresa.

Exceto nessa hipótese, no processo de recuperação o administrador judicial não pratica qualquer ato de gestão da empresa, limitando-se sua atuação à fiscalização do cumprimento, pelo devedor, das obrigações constantes do plano de recuperação judicial.

Nada impede, porém, que, afastado o devedor ou seus administradores, o próprio administrador judicial venha a ser eleito, em assembleia geral de credores, o gestor judicial, cumulando o exercício das duas funções ${ }^{207}$. Mas apesar não haver impedimento, essa cumulação não se mostra adequada ao processo de recuperação judicial, porquanto a uma mesma pessoa cumulará a função de gerir a empresa e de fiscalizar a própria gestão.

Acrescente-se, por outro lado, que a atividade de fiscalização exercida pelo administrador judicial no processo de recuperação tem por objeto a gestão da devedora como um todo e o cumprimento do plano aprovado pelos credores, não competindo ao administrador judicial fiscalizar especificamente o cumprimento de um contrato ou negócio em especial ou, nas palavras de KUGELMAS e PINTO (2009, p. 201)

${ }^{207}$ A cumulação de funções já se verificou, por exemplo, na recuperação judicial de Neomater Ltda., que se processa perante a $3^{\mathrm{a}}$ Vara Cível de São Bernardo do Campo, Estado de São Paulo (processo $\mathrm{n}^{\mathbf{o}}$ 564.01.2009.043211-3). 
o administrador judicial fiscaliza a empresa para saber como estão as vendas, o faturamento, os recebimentos e, principalmente, os pagamentos que realiza e se estão de acordo com o que foi estabelecido no plano de recuperação, para que não ocorra nenhum favorecimento a um credor em detrimento dos outros.

Não compete ao administrador judicial interferir no processo de decisão das medidas administrativas e/ou comerciais que são adotadas pelo devedor, não podendo ele, a rigor, sequer participar ou acompanhar as reuniões de diretoria: sua função, em princípio, é apenas fiscalizatória. Em suma, "é vedado ao administrador judicial pretender intervir na forma pela qual se ponham em prática as medidas previstas no plano de recuperação adotado" (PIMENTA, 2006, p. 172).

\section{Os deveres e a responsabilidade do gestor judicial}

Os deveres dos administradores das sociedades empresárias, segundo CORRÊA-LIMA (2005, p. 180), são, basicamente, o de obediência à lei e ao estatuto (ou ao contrato social), diligência e lealdade, podendo o regramento jurídico dos deveres dos administradores ser resumido na parêmia latina honeste vivere, nenimem laedere, suum cuique tribuere (viver honestamente, não prejudicar a ninguém e dar a cada um o que é seu).

Esses deveres são exigidos de todo e qualquer administrador, pois como explica COELHO (2007, p. 442), os deveres de diligência e lealdade são preceitos gerais de conduta que incidem sobre toda pessoa que administre interesses de terceiros, aplicandose, portanto, ao procurador, ao mandatário, ao administrador judicial da massa falida, ao liquidante e também ao administrador de sociedades e de empresas individuais de responsabilidade limitada.

Por ser um preceito geral de conduta, esses deveres também são impostos ao gestor judicial, pois, eleito pelos credores, é órgão da recuperação judicial que, sem ingressar na pessoa jurídica, administra a empresa do devedor afastado. Bem por isso, FONSECA (2009, p. 449) destaca que

o gestor judicial está, ainda, sujeito à responsabilização por dolo ou culpa, prevista no art. 32, que, especificamente para suas funções, envolve o descumprimento de deveres próprios de um administrador de empresa. Assim, deve agir com lealdade, diligência e transparência, sob pena de 
ser responsabilizado pelos prejuízos causados à empresa, ao devedor ou aos credores.

Impõe-se, em consequência, o exame dos deveres impostos ao administrador de sociedades empresariais (e, consequentemente, ao gestor judicial), deveres esses cujo descumprimento importará sua responsabilidade pessoal.

\section{1. $\quad O$ dever de diligência}

$\mathrm{O}$ art. 153 da Lei $\mathrm{n}^{\circ}$ 6.404/76, aplicável tanto às sociedades por ações quanto às limitadas em cujos contratos sociais se estabeleceu, nos termos do parágrafo único do artigo 1.053 do Código Civil, a regência supletiva, nas omissões, pelas normas que regulam as sociedades por ações, impõe ao administrador o dever de diligência na condução dos negócios sociais. Dispõe o referido art. 153: "O administrador da companhia deve empregar, no exercício de suas funções, o cuidado e diligência que todo homem ativo e probo costuma empregar na administração dos seus próprios negócios."

Já o art. 1.011 do Código Civil, que rege a sociedade simples e incide supletivamente às limitadas por força do disposto no caput do art. 1.053 do Código Civil, tem redação muito similar à do art. 153 da Lei das Sociedades por Ações, e também impõe ao administrador o dever de diligência no exercício do cargo: "o administrador da sociedade deverá ter, no exercício de suas funções, o cuidado e a diligência que todo homem ativo e probo costuma empregar na administração e de seus próprios negócios."

Dessas normas legais decorre, portanto, que o dever de diligência é legalmente imposto tanto ao administrador da sociedade por ações quanto ao da limitada, quer ela seja regida supletivamente pelas normas da sociedade simples, quer incidam nas omissões as regras da Lei $n^{\circ}$ 6.404/76.

A definição do dever de diligência, porém, não é fácil, pois, como lembra PARENTE (2005, p. 37), as legislações em geral não o conceituam, mas recorrem a figuras como a do bom pai de família ou a do homem de negócio ordenado e cuidadoso, razão pela qual a conduta do administrador seria pautada pelo que se espera de um homem médio. Em consequência, prossegue a autora (2005, p. 41), surge a questão de como se qualificar um 
administrador como diligente, pois a lei não prevê (e nem poderia) que atos podem ou não ser praticados para a realização do objeto social, de modo que os administradores sabem qual o fim a atingir, mas terão de apurar qual o meio adequado para fazê-lo.

Exatamente porque não existe norma legal estabelecendo em que consiste o dever de diligência, alguns autores elaboraram relações exemplificativas de atos que podem (ou devem) ser praticados pelos administradores, destacando-se TEIXEIRA DE FREITAS $^{208}$ (1860, v. 7, p. 1.130) e PONTES DE MIRANDA ${ }^{209}$ (1972, t. 49, p. 406).

Para VERÇOSA $\left(2006^{\text {b }}\right.$, p. 191), contudo, é absolutamente inútil a elaboração de listas de atos que podem (ou devem) ser praticados pelos administradores, uma vez que

\begin{abstract}
${ }^{208}$ Consta do art. 3.126 do Esboço: “Art. 3.126. Entrão na classe dos negocios ordinarios da administração da sociedade: $1^{\circ}$ A cobrança das entradas sociaes, e suas quitações (Art. 3050). $2^{\circ}$ A das perdas sociaes demonstradas nos balanços anuaes, ou intermediarios, nos casos em que os socios tiverem obrigação de logo paga-las. $3^{\circ} \mathrm{A}$ cobrança das dividas activas da sociedade, suas quitações e reformas. $4^{\circ} \mathrm{O}$ pagamento das dividas passivas da sociedade (Art. $2881 \mathrm{n} .1^{\circ}$ ). $5^{\circ}$ A entrega á cada um dos socios das quantias que, segundo o contracto social, tenha direito de perceber para suas despezas particulares, ou para outro fim. $6^{\circ}$ A distribuição dos lucros sociaes demonstrados nos balanços annuaes, ou intermediários, se os socios tiverem direito para retira-los. $7^{\circ}$ A assignatura de concordatas de devedores fallidos, ainda que com rebate; assim como a de contractos de união para liquidação e distribuição de massas fallidas (Art. 2881 n. $4^{\circ}$ ). $8^{\circ} \mathrm{A}$ venda, e alienação em geral por titulo oneroso, de cousas moveis ou immoveis que não pertenção ao capital fixo da sociedade, ou destinadas á sêr vendidas (Art. 2881 n. $6^{\circ}$ ). $9^{\circ}$ A compra á dinheiro ou á credito de cousas moveis ou immoveis, que sejão necessarias para as operações da sociedade, ou para seu uso. $10^{\circ}$ Dar de aluguel ou arrendamento cousas moveis ou immoveis por tempo que não exceda o da duração da sociedade, não se oppondo taes contractos ao fim della, e não sendo o arrendamento de immoveis por mais de nove annos (Art. 2881 n. $9^{\circ}$ ). $11^{\circ}$ Tomar de aluguel ou arrendamento, se fôr necessario, cousas moveis e immoveis, não sendo igualmente o arrendamento de immoveis por mais de nove annos. $12^{\circ}$ Empregar no serviço da sociedade guarda-livros, prepopstos, caixeiros, trabalhadores, e agentes de qualquer especie , se tambem fôr necessario. $13^{\circ}$ Contractar empreitadas para reparação dos immoveis e outros bens da sociedade, tanto quanto seja necessrio para conserva-los em bom estado. $14^{\circ}$ Intentar em nome da sociedade contra terceiros, ou contra qualquer dos socios, acções, e procedimentos judiciaes, para reivindicação de seus bens, cobrança de suas dividas, e conservação de seus direitos. $15^{\circ}$ Defendêr a sociedade nas acções, e procedimentos judiciaes, que contra ella intentarem terceiros, ou qualquer dos socios."
\end{abstract}

209 Afirma PONTES DE MIRANDA: “Como órgãos da sociedade, os sócios gerentes podem exercer, em presentação: a) os direitos da sociedade a cobrança das quotas ou sua integralização; b) em caso de perdas sociais, constantes dos balanços anuais, ou dos balanços intercalares, exigir dos sócios que tenham de responder por elas a prestação ou as prestações respectivas; c) cobrar as dívidas ativas da sociedade, dar quitação, ou reformá-las ou nová-las; d) pagar as dívidas passivas da sociedade; e) prestar a cada sócio o que, de conformidade com o contrato social, tenham de receber para despesas próprias (ou outros fins); f) proceder à distribuição dos lucros sociais, a que, segundo o contrato social e o balanço, os sócios tenham direito; g) assinar as concordatas dos devedores, assim como o que concerne à distribuição das massas concursais; $h$ ) alienar ou fazer outros negócios jurídicos, que caibam na atividade social, desde que o bem não faça parte do capital social; i) adquirir, a dinheiro, ou a crédito, bens móveis ou imóveis, que sejam necessários às operações da sociedade, ou para seu uso ou consumo; j) dar em locação bens móveis ou imóveis desde que o prazo não exceda o da duração da sociedade, nem se choque com o contrato social; k) tomar em locação bens móveis ou imóveis, por tempo que não exceda o da duração da sociedade, nem contra o que resulta do contrato social; 1) assinar, pela sociedade, contratos de trabalho, que forem necessários à atividade social; m) contratar empreitada, ou outros contratos de que a sociedade necessite; n) propor ações e opor exceções, que cabem à sociedade e defender a sociedade nas ações propostas contra ela e exceções que contra ela forem opostas." 
essas relações se mostrariam sempre incompletas, quer em função das características peculiares de cada sociedade, quer em decorrência do dinamismo das atividades empresariais. Em consequência, toda e qualquer lista que venha a ser elaborada será sempre meramente exemplificativa, e não exaustiva, não servindo, portanto, para dar orientação segura aos administradores. Ademais, como a atividade empresarial visa à implementação do objeto social para a realização de lucro, a conduta dos administradores está vinculada aos parâmetros definidos pelos sócios no contrato social, em especial na definição do objeto social.

Na opinião de COELHO (2007, p. 246), a única forma de tornar objetiva a apuração do cumprimento do dever de diligência, inclusive passível de realização de perícia, é mediante o confronto da conduta do administrador com as modernas técnicas de administração empresarial, de modo que, para ser diligente, o administrador deve obedecer aos conhecimentos tecnológicos preconizados em administração de empresas, fazendo o que as técnicas indicam que deva ser feito, e deixando de fazer o que as técnicas indicam não deva ser praticado.

Do mesmo modo, EIZIRIK (2005, p. 68) salienta que o conceito de bom pai de família está ultrapassado como modelo de cumprimento do dever de diligência, pois a conduta do administrador deve ser apurada caso a caso, comparando os atos praticados pelo administrador com o modo pelo qual atuaria um bom administrador de empresas em situação semelhante, ou seja, no mesmo tipo de negócio e em circunstâncias semelhantes.

O exame da conduta do administrador para verificar se o dever de diligência foi cumprido é de fundamental importância, porquanto só terá responsabilidade pessoal o administrador que violar esse dever.

Bem por isso LUCENA (2005, p. 402) acrescenta que o administrador que não violou o dever de diligência, ou seja, que pautou sua conduta pelas práticas preconizadas pelas modernas técnicas de administração empresarial, não pode ser responsabilizado apenas porque não atingiu o êxito desejado na condução do negócio, pois não há fundamento para a responsabilidade, ainda que a sociedade venha a se tornar insolvente ou a ter sua falência declarada. A responsabilidade, assim, decorre da violação do dever de conduta, não do resultado apurado no negócio. 
Acrescente-se, por fim, com REQUIÃO (1988, p. 175), que o dever de diligência do administrador é para com a sociedade e não para com os sócios (ou grupo de sócios), acionistas (ou grupo de acionistas) ou conselheiros que o elegeu. Sua gratidão para com o grupo que o elegeu não tem qualquer reflexo no dever de diligência que tem para com a sociedade que administra, razão pela qual o dever de diligência é sempre o mesmo, quer o administrador esteja ligado a um grupo de sócios ou acionistas, quer não tenha relação com qualquer deles.

\subsection{O dever de lealdade}

Além do dever de diligência, o direito positivo brasileiro impõe aos administradores de sociedades o dever de lealdade, o qual está disciplinado em diversos artigos da Lei das Sociedades por Ações, que descrevem comportamentos que o administrador deve, ou não, adotar.

Dentre esses artigos destaca-se o 155, segundo o qual "o administrador deve servir com lealdade à companhia e manter reserva sobre os seus negócios", sendo-lhe vedado praticar os atos exemplificativamente descritos nos incisos ${ }^{210}$ desta mesma norma da Lei $n^{\circ} 6.404 / 76$.

Porque imposto na Lei das Sociedades por Ações, o dever de lealdade é também exigido do administrador de sociedades limitadas em cujo contrato social ajustou-se a regência supletiva, nos casos de omissão, pelas normas que regem as companhias.

Mas ao administrador de sociedades limitadas regidas supletivamente pelas normas das sociedades simples também se impõe o dever de lealdade. É que esse dever, assim como o de diligência, constitui um preceito geral de conduta, motivo pelo qual é exigido do administrador de toda e qualquer sociedade, ainda que não empresarial.

\footnotetext{
${ }^{210}$ Os atos vedados ao administrador relacionados nos incisos do art. 155 da Lei no 6.404/76 são os seguintes: "I - usar, em benefício próprio ou de outrem, com ou sem prejuízo para a companhia, as oportunidades comerciais de que tenha conhecimento em razão do exercício de seu cargo; II - omitir-se no exercício ou proteção de direitos da companhia ou, visando à obtenção de vantagens, para si ou para outrem, deixar de aproveitar oportunidades de negócio de interesse da companhia; III - adquirir, para revender com lucro, bem ou direito que sabe necessário à companhia, ou que esta tencione adquirir."
} 
Tanto assim é que diversas normas que regem a sociedade simples, embora não empreguem expressamente o termo "lealdade", descrevem exemplificativamente condutas caracterizadoras de violação ao dever de lealdade, tais como "aplicar créditos ou bens sociais em proveito próprio ou de terceiros" (Código Civil, art. 1.017, caput) ou ter em qualquer negócio interesse contrário ao da sociedade e mesmo assim tomar parte da deliberação (Código Civil, art. 1.017, parágrafo único).

CORRÊA-LIMA (2005, p. 181), após explicar que "lealdade significa sinceridade, franqueza, honestidade", apresenta rol exemplificativo de modalidades do dever de lealdade constantes da Lei das Sociedades por Ações (as quais, com as devidas adaptações ao tipo societário, também incidem sobre o administrador das sociedades limitadas), destacando-se:

(a) dever de prestar as informações de que trata o art. 157, o que inclui informações aos acionistas, à Bolsa de Valores de São Paulo e à Comissão de Valores Mobiliários;

(b) dever de guardar sigilo sobre informações que não tenham sido ainda divulgadas ao mercado, bem como proibição de utilizar essa informação privilegiada - art. $155, \S \S 1^{\circ} \mathrm{e}$ $4^{\mathrm{o}}$;

(c) “dever de não usurpar oportunidade da companhia" - art. 155, incisos I, II e III;

(d) "dever de só negociar com a companhia em condições razoáveis e equitativas" - art. 156 e $117, \S 1^{\circ}$, alínea “f”;

(e) "dever de não se valer de informações privilegiadas na negociação de valores mobiliárias da companhia" - art. $155, \S 1^{\text {o; }}$;

(f) dever imposto ao administrador acionista de votar no interesse da companhia - art. 115;

(g) dever imposto ao administrador acionista de se abster de votar em certas circunstâncias, tais como nas deliberações a respeito das contas prestadas pela administração - art. 134, § $1^{\circ}$ 
(h) "dever de abster-se de praticar ato de liberalidade à custa da companhia" - art. 154, § $2^{\circ}$, aliena "a";

(i) "dever de não tomar por empréstimo bem da companhia sem prévia autorização da assembleia geral ou do conselho de administração" - art. 154, § 2º aliena "b";

(j) "dever de não usar, em proveito próprio, de sociedade em que tenha interesse, ou de terceiros, de bens, serviços ou crédito da companhia" - art. 154, § $2^{\circ}$, aliena "b";

(k) "dever de não receber, sem autorização estatutária ou da assembleia geral, qualquer modalidade de vantagem pessoal, direta ou indireta, em razão do exercício do cargo de administrador" - art. 154, § $2^{\circ}$, aliena “c"; e

(1) "dever de garantir a gestão, quando exigido pelo estatuto social."

Em suma, segundo SILVA (2007, p. 19),

o dever de lealdade está relacionado com transações em que há: (i) conflito de interesse entre o administrador e a companhia, (ii) conflito de interesse entre companhias por terem administradores em comum; (iii) vantagem obtida indevidamente por administrador em oportunidades que pertenciam à companhia; (iv) administrador competindo com a companhia; (v) informações falsas ou indevidas aos acionistas; (vi) negociação do insider; (vii) abuso da minoria; e (viii) venda de controle.

Do mesmo modo que se verifica com o dever de diligência, o cumprimento do de lealdade não gera responsabilidade pessoal do administrador, ainda que a empresa não alcance os resultados planejados ou, até mesmo, venha a sofrer perdas, uma vez que só haverá responsabilização pessoal no caso de violação desse dever de conduta.

\section{3. $\quad O$ dever de obediência}

O dever de obediência, assim como os deveres de diligência e de lealdade, também é um preceito geral de conduta imposto ao administrador de toda e qualquer sociedade. Este dever está consagrado no art. 158 da Lei das Sociedades por Ações, segundo o 
qual "o administrador não é pessoalmente responsável pelas obrigações que contrair em nome da sociedade e em virtude de ato regular de gestão; responde, porém, civilmente, pelos prejuízos que causar, quando proceder: I - dentro de suas atribuições ou poderes, com culpa ou dolo; II - com violação da lei ou do estatuto."

Dessa norma legal decorre que, se o administrador obedecer a lei e o estatuto (ou o contrato social), apenas a pessoa jurídica por ele presentada é que responderá pelas obrigações contraídas, nada podendo ser exigido pessoalmente do administrador, pois quem agiu foi a própria sociedade, devidamente presentada por seu órgão administrativo. Porém, haverá responsabilidade pessoal do administrador, pelos prejuízos causados à sociedade, se sua conduta violar a lei ou ao estatuto ou contrato social ${ }^{211}$.

Porque o respeito à lei e ao estatuto social (ou ao contrato social) não gera responsabilidade pessoal, informa VERÇOSA $\left(2006^{\mathrm{b}}\right.$, p. 188) que o administrador não pode desconhecer o contrato social (ou o estatuto social), nem alegar que o descumprimento decorreu de sua ignorância quanto às disposições estatutárias ou contratuais, em especial no tocante aos seus poderes e competências. Neste caso, o administrador será pessoalmente responsável pelas obrigações contraídas pela sociedade, visto que não tinha poderes para presentá-la na prática daquele ato que violou a lei ou o contrato social (ou estatuto).

Mas o dever de obediência imposto ao administrador não elimina sua discricionariedade na condução dos negócios, pois como aponta GUERREIRO (1981, p. 74), nem a lei, nem o contrato ou estatuto social estabelecem, com precisão, que atos de gestão são considerados regulares, de modo que dois fatores são importantes para a aferição da conduta do administrador, porque limitam sua discricionariedade, a saber, o objeto social e o atendimento ao interesse social.

\footnotetext{
${ }^{211}$ O STJ, no Recurso Especial no 100.739/SP, Relator Ministro Ari Pargendler, DJU $1^{\circ} .2 .1999$, p. 138, decidiu: "Tributário. Sociedade anônima e/ou sociedade por quotas de responsabilidade limitada. Limites da responsabilidade do diretor e/ou sócio-gerente. Quem está obrigada a recolher os tributos devidos pela empresa é a pessoa jurídica, e, não obstante ela atue por intermédio de seu órgão, o diretor ou sócio-gerente, a obrigação tributária é daquela, e não destes. Sempre, portanto, que a empresa deixa de recolher o tributo na data do respectivo, a impontualidade ou a inadimplência é da pessoa jurídica, não do diretor ou do sóciogerente, que só respondem, e excepcionalmente, pelo débito, se resultar de atos praticados com excesso de mandato, ou infração à lei, contrato social ou estatutos, exatamente nos termos do que dispõe o artigo, 135, inciso III, do Código Tributário Nacional."
} 


\subsection{Retomando: os deveres e a responsabilidade do gestor judicial}

Os deveres de diligência, lealdade e obediência (à lei e ao contrato ou estatuto social), como se disse, são preceitos gerais de conduta exigidos de toda e qualquer pessoa que administra bens e/ou direitos de terceiros. Especificamente em relação ao gestor judicial, cuja função é, em virtude do afastamento do devedor, conduzir a empresa em recuperação judicial, esses deveres, em princípio, também são exigíveis.

Com efeito, o gestor judicial, enquanto órgão da recuperação judicial e auxiliar do Juízo, tem o dever de ser diligente na condução dos negócios da empresa em recuperação judicial, aplicando todas as modernas técnicas preconizadas pela ciência da administração de empresas. Não tem o dever, contudo, de obter o resultado pretendido, quer pelo devedor (que ele substitui), quer pelos credores que o elegeram. Isto porque, embora sua conduta deva ter por norte a superação da crise econômico-financeira da empresa, sua obrigação é a de aplicar as modernas técnicas de administração, não a de alcançar a solução da crise econômica.

Em consequência, se o devedor não cumprir o plano de recuperação judicial e vier a ter sua falência decretada, o gestor judicial não responderá pessoalmente (pelos atos praticados enquanto condutor da atividade) se ele tiver cumprido seu dever de diligência, porquanto o cumprimento de seu dever, repita-se, independe do resultado efetivamente obtido na gestão da empresa.

De igual modo, o dever de lealdade do administrador também não sofre qualquer alteração em virtude do fato de ter sido requerida a recuperação judicial, pois o administrador (escolhido pelos sócios na forma do contrato ou estatuto social) tem, sempre, o dever de agir com sinceridade e honestidade para com a empresa que gere, abstendo-se de praticar atos que importem em aproveitar oportunidades que seriam da sociedade, baseados em informações privilegiadas, em conflito de interesses, etc.

No caso de afastamento do devedor e eleição, pelos credores, de gestor judicial, o dever de lealdade continua sendo exigido da pessoa responsável pela condução das atividades da empresa em crise. Isto porque, o gestor judicial tem o dever de agir com sinceridade, praticando todos os atos necessários para que a empresa aproveite as oportunida- 
des que lhe surgirem, abstendo-se de (a) praticar atos em conflito de interesses; (b) obter vantagens indevidas; (c) competir com a empresa devedora; (d) utilizar informações privilegiadas, etc.

Acrescente-se, ainda, que assim como o dever de lealdade (do mesmo modo que o de diligência), do administrador é para com a sociedade, não para com seus sócios ou acionistas que o elegeram, o dever de lealdade exigido do gestor judicial é para com a empresa que conduz, não para com os credores (ou determinado grupo de credores).

Por fim, tratando-se de administrador eleito pelos sócios (ou acionistas), a recuperação judicial não implica alterações no dever de obediência que lhe é imposto, porquanto tem ele a obrigação de cumprir a lei e o contrato (ou estatuto) social. O que ocorre, em relação ao administrador, é simplesmente um incremento, por força de expressa disposição legal, nas limitações que lhe são impostas. Em outras palavras, ao administrador continua sendo imposto o dever de obediência à lei e ao contrato (ou estatuto) social, mas o que se altera é que sobre a sociedade passam a incidir novos regramentos jurídicos, quais sejam, a LREF e o plano de recuperação judicial aprovado pelos credores, que pode contemplar limites à liberdade de gestão dos administradores, cujo descumprimento gerará sua responsabilidade pessoal.

E o art. 66 da LREF, por exemplo, dispõe que "após a distribuição do pedido de recuperação judicial, o devedor não poderá alienar ou onerar bens ou direitos de seu ativo permanente, salvo evidente utilidade reconhecida pelo juiz, depois de ouvido o Comitê, com exceção daqueles previamente relacionados no plano de recuperação judicial." É a própria lei, assim, que impõe um limite à liberdade do administrador, pois determinados atos somente poderão ser praticados se houver aprovação de terceiros.

Percebe-se, portanto, que a recuperação judicial não importa alteração substancial no dever de obediência à lei e ao contrato (ou estatuto) social exigido dos administradores, sob pena de sua responsabilidade pessoal ${ }^{212}$.

${ }^{212} \mathrm{O}$ TJSP, no Agravo de Instrumento no 0022059-02.2011.8.26.0000, Câmara Reservada à Falência e Recuperação, Relator Desembargador Lino Machado, j. 20.09.2011, v.u., decidiu: "Como é cediço, os estatutos e a lei de regência das sociedades anônimas impõem uma série de deveres aos diretores e conselho de administração e que são levadas aos demais acionistas. No caso da Beter, justamente por estar em recuperação judicial, mantém a livre administração de suas atividades, não obstante deva observar o princípio da transparên- 
No caso, porém, de afastamento do devedor, o dever de obediência imposto ao gestor judicial é um pouco diverso: do mesmo modo que se verifica com os administradores, exige-se dele o cumprimento da lei (o que inclui, por óbvio, a LREF) e do plano de recuperação judicial aprovado pelos credores. Mas não se lhe exige o cumprimento do contrato (ou estatuto) social. E isto por uma razão simples. Sendo o devedor sociedade empresária limitada ou sociedade por ações, afastada, na hipótese do art. 65 da LREF, é a própria pessoa jurídica, de modo que o gestor judicial assume a administração da empresa devedora de fora da estrutura societária, razão pela qual não está ele sujeito ao contrato (ou estatuto) social, nem a eventuais acordos de quotistas ou acionistas. Subordina-se o gestor judicial, contudo, à cláusula do contrato (ou estatuto) social que fixa o objeto social da empresa.

Em outras palavras, porque o gestor judicial não ingressa na sociedade empresária (pois, repita-se, a própria pessoa jurídica será afastada), ele não está vinculado a eventuais acordos parassociais, não participa de possíveis atos societários que venham a ser implementados, e não pode ser exigido dele o cumprimento de dispositivos estabelecidos pelos sócios no contrato (ou estatuto) social, com exceção da cláusula que fixa o objeto social.

Verifica-se, assim, que do gestor judicial exige-se o cumprimento dos deveres de diligência, lealdade (para com a empresa que administra) e obediência à lei, sob pena de responsabilidade pessoal ${ }^{213}$. Tratando-se de responsabilidade subjetiva (que exige dolo ou culpa, nexo de causalidade e dano), cumpridos os deveres que lhe são impostos, o gestor não responderá pessoalmente pelos atos praticados, ainda que a recuperação judicial venha a ser convolada em falência.

cia e remeter aos seus credores, sob a fiscalização do administrador judicial e tutela do juízo da recuperação judicial, todas as questões que afetem a superação do seu estado de crise, nos termos do plano de recuperação judicial aprovado."

213 O STJ, no Recurso em Mandado de Segurança $n^{\mathbf{o}}$ 26.826-SP, $2^{\text {a }}$ Turma, Relator Ministro Herman Benjamin, j. 23.06.2009, v.u., que tratava da necessidade de inscrição estadual para a continuação provisória das atividades do falido, decidiu que "a nova inscrição estadual será dada à Massa Falida (...) a responsabilidade pela regularidade das operações comerciais realizadas pela Massa Falida não é dos antigos gestores, que teriam cometido os ilícitos listados pelo Estado, mas sim do administrador judicial indicado pelo juízo falimentar. Importante lembrar que eventual inadimplência, inclusive no que se refere ao desrespeito às preferências do crédito tributário, poderá redundar em responsabilidade pessoal do administrador judicial, nos termos dos arts. 134, V, e 135, I, do CTN." 
Acrescente-se, por fim, que além de sua responsabilização pessoal pelos danos causados (à empresa, à pessoa jurídica afastada ou aos credores), a violação dos deveres fiduciários que lhe são impostos poderá acarretar o afastamento do gestor judicial pelo juiz, como alerta FONSECA (2009, p. 450):

Descumprindo o gestor judicial seus deveres, desobedecendo a preceito da lei de Falências, agindo com omissão, negligência, praticando ato lesivo ao devedor ou a terceiros, sua substituição pode ser determinada pelo juiz, de ofício ou a requerimento de qualquer interessado ou do Ministério Público, nos termos do $\S 2^{\circ}$ do art. 30 e do caput do art. 31 .

A destituição do gestor judicial pela infração de seus deveres, importará na convocação, pelo juiz, de outra assembleia geral para eleger novo gestor judicial em substituição ao anterior, hipótese na qual o destituído, por razões óbvias, estará impedido de ser eleito pelos credores.

\section{A remuneração do gestor judicial}

O art. 65 da LREF, como já se disse, estabelece que se o devedor for afastado, o juiz convocará assembleia geral de credores para deliberar a respeito da escolha do gestor judicial, que "assumirá a administração das atividades do devedor", aplicando-se-lhe as normas que regulam os deveres, os impedimentos e a remuneração do administrador judicial.

Assim como o administrador judicial, o gestor exerce função auxiliar da Justiça, de modo que não há vínculo ou relação de emprego entre as pessoas que integram esses órgãos da recuperação judicial e o devedor, que é o responsável pelo pagamento dessa remuneração. Em consequência, não têm esses honorários caráter salarial, e seu valor e forma de pagamento são fixados pelo juiz, em função da capacidade de pagamento do devedor e do grau de complexidade do trabalho.

Diversamente do que dispunha a revogada Lei de Falências (que estabelecia como teto máximo para a remuneração do síndico e do comissário um percentual do montante obtido pela massa falida com a alienação dos bens arrecadados ou do total das dívidas 
quirografárias sujeitas à concordata, percentual esse que era reduzido à medida que aumentava a importância da massa ${ }^{214}$ ), a atual legislação ${ }^{215}$ dispõe apenas que a remuneração do administrador judicial não pode exceder a quantia correspondente a $5 \%$ (cinco por cento) do valor das dívidas sujeitas à recuperação judicial ou dos bens alienados na falência, sem qualquer escalonamento.

E se a LREF fixou apenas o percentual máximo do valor devido ao administrador, não estabeleceu ela, do mesmo modo que o revogado Decreto-Lei, o piso mínimo, de modo que a nova legislação deu maior autonomia ao juiz na fixação do valor devido ao administrador judicial, a qual poderá ser objeto de revisão na hipótese de recurso (TOMAZETTE, 2011, p. 119).

Especificamente em relação ao gestor judicial, o critério para a fixação de seu valor é o mesmo empregado para os honorários do administrador judicial: não há piso mínimo e seu montante não pode ultrapassar a quantia correspondente a 5\% (cinco por cento) dos débitos sujeitos à recuperação.

A própria LREF, contudo, estabelece os critérios que devem nortear a fixação da remuneração do administrador judicial ${ }^{216}$, a saber, a capacidade de pagamento do devedor, a complexidade do trabalho e os valores praticados no mercado para o desempenho de atividades semelhantes.

Interpretando os critérios estabelecidos pela LREF para a fixação da remuneração do administrador judicial, o TJSP, por sua Câmara Reservada à Falência e Recupera-

${ }^{214}$ Art. 67. O síndico tem direito a uma remuneração, que o juiz deve arbitrar, atendendo à sua diligência, ao trabalho e à responsabilidade da função e à importância da massa, mas sem ultrapassar de $6 \%$ até Cr\$100.000,00; de 5\% sobre o excedente até Cr\$200.000,00; de 4\% sobre o excedente até Cr $\$ 500.000,00 ;$ de $3 \%$ sobre o excedente até $\mathrm{Cr} \$ 1.000 .000,00$; de $2 \%$ sobre o que exceder de $\mathrm{Cr} \$ 1.000 .000,00$. $\$ 1^{\circ} \mathrm{A}$ remuneração é calculada sobre o produto dos bens ou valores da massa, vendidos ou liquidados pelo síndico. Em relação aos bens que constituir em objeto de garantia real, o síndico perceberá comissão igual a que, em conformidade com a lei, for devida ao depositário nas execuções judiciais. $\S 2^{\circ}$ No caso de concordata, a percentagem não pode exceder a metade das taxas estabelecidas neste artigo, e é calculada somente sobre a quantia a ser paga aos credores quirografários.

215 Art. 24, $\S 1^{\circ}$ - Em qualquer hipótese, o total pago ao administrador judicial não excederá $5 \%$ (cinco por cento) do valor devido aos credores submetidos à recuperação judicial ou do valor de venda dos bens na falência.

216 Art. 24. O juiz fixará o valor e a forma de pagamento da remuneração do administrador judicial, observados a capacidade de pagamento do devedor, o grau de complexidade do trabalho e os valores praticados no mercado para o desempenho de atividades semelhantes. 
ção, Relator o Desembargador Manoel de Queiroz Pereira Calças, ao julgar o Agravo de Instrumento $n^{\circ}$ 990.10.031707-5 (j. 19.10.2010), decidiu que

\begin{abstract}
O primeiro critério instituído pelo legislador é a "capacidade de pagamento do devedor'. Esta, será estimada, levando-se em conta a documentação contábil, a relação dos credores e respectivo passivo, bem como a relação dos empregados com suas funções e salários, a teor do artigo 51, I a IV, da Lei $\mathrm{n}^{\mathrm{o}} 11.101 / 2005$. Do conjunto de tais documentos, o magistrado aferirá a capacidade de pagamento da devedora, não devendo se olvidar que a devedora está em crise econômico-financeira e da aplicabilidade do princípio da preservação da empresa.

O segundo critério a ser observado consiste no 'grau de complexidade do trabalho'. O juiz, com sua experiência no exercício da judicatura, sob o enfoque do artigo 335 do Código de Processo Civil, estimará o trabalho a ser realizado pelo administrador judicial, analisando-se o número de credores, o valor do passivo, etc.

Por fim, estabelece a legislação que o magistrado também observará 'os valores praticados no mercado para o desempenho de atividades semelhantes'. O primeiro parâmetro a ser ponderado é a remuneração dos profissionais da área jurídica, eis que a função do administrador é eminentemente judicial, já que auxiliar do Poder Judiciário. Daí devem ser considerados os vencimentos dos Magistrados, dos membros do Ministério Público, Procuradores Federais e Estaduais, não se olvidando o teto constitucional vinculado aos vencimentos dos Ministros do Supremo Tribunal Federal. Isto porque, por mais complexa que seja a função do administrador judicial, não se pode deixar de considerar que caberá ao juiz decidir todos os requerimentos, incidentes e, superiormente ao seu auxiliar, terá a responsabilidade pela direção do processo, além de todos os outros feitos sob sua jurisdição.
\end{abstract}

Tratando-se de gestor judicial, os critérios para a fixação de sua remuneração, são os mesmos utilizados para a definição dos honorários do administrador judicial, a saber, a saber, a capacidade de pagamento do devedor, a complexidade do trabalho e os valores praticados no mercado para o desempenho de atividades semelhantes.

Ocorre que, diferentemente do administrador judicial, cuja função, no processo de recuperação, é fundamentalmente a de fiscalização, o gestor judicial efetivamente administra a empresa em crise (negociando com credores, fornecedores, empregados, definindo estratégias de negócios, etc.), de modo que a atividade que exerce é mais complexa que a do administrador judicial.

Bem por isso, quanto aos valores praticados no mercado, a remuneração do gestor judicial não deve ter como parâmetro os "vencimentos dos Magistrados, dos mem- 
bros do Ministério Público, Procuradores Federais e Estaduais", mas o pago a executivos que administram sociedades similares, devendo ser levado em consideração, porém, que o devedor está enfrentando crise econômico-financeira.

Determina a LREF (art. 24, § $2^{\circ}$ ), por fim, que "será reservado 40\% (quarenta por cento) do montante devido ao administrador judicial para pagamento após atendimento do previsto nos arts. 154 e 155 desta Lei”, ou seja, parte relevante da remuneração será paga apenas após a apresentação das contas finais, sua aprovação e juntada aos autos do relatório final da falência.

Para VERÇOSA (2007, p. 178), como a lei vinculou o pagamento dessa parte final da remuneração a dois eventos distintos, o juiz deverá determinar que o saldo seja quitado em "duas parcelas em montantes que fixará a seu critério." A lei, porém, não determina que o pagamento seja feito em duas etapas distintas, mas apenas exige a reserva.

Como essa norma que determina a reserva de parte da remuneração do administrador judicial vincula o pagamento do saldo a dois atos que são praticados apenas no processo de falência, debate-se se no processo de recuperação judicial também haveria essa obrigação, visto que não há norma expressa nesse sentido. Ao contrário, como observa TOLEDO (2007, p. 65), o Projeto de Lei n 4.376-B/1993 (Projeto de Lei da Câmara) continha no art. $71, \S 1^{\circ}$, disposição determinando que, no processo de recuperação judicial, a quantia correspondente a $20 \%$ da remuneração do administrador judicial seria paga após a apresentação do relatório final a respeito da execução plano, norma esta que não constou da versão final aprovada.

Segundo MILANI (2011, p. 148), embora não haja norma expressa referente à reserva de parte da remuneração do administrador judicial no processo de recuperação, a obrigatoriedade da reserva estaria implícita no art. 63, inc. I, segundo o qual a sentença que encerra o processo de recuperação determinará "o pagamento do saldo de honorários ao administrador judicial, somente podendo efetuar a quitação dessas obrigações mediante prestação de contas, no prazo de 30 (trinta) dias, e aprovação do relatório previsto no inciso III do caput deste artigo.” No mesmo sentido manifesta-se TOMAZETTE (2011, p. 120), para quem a reserva deve ser de $40 \%$ (quarenta por cento) do total da remuneração. 
Não obstante essa norma do art. 63, inc. I, e a posição desses doutrinadores, o TJRJ, por sua $19^{a}$ Câmara Cível, Relator o Desembargador Ferdinaldo Nascimento, ao julgar o Agravo de Instrumento n ${ }^{\circ} 2009.002 .41700$ (j. 09.03.2010), decidiu que a reserva de parte dos honorários para pagamento ao final não se aplica à recuperação judicial porque neste procedimento o administrador judicial não tem por função a gestão do devedor, mas fundamentalmente o acompanhamento do cumprimento do plano de recuperação pelo devedor, razão pela qual as contas que apresenta não são de sua gestão, mas das atividades da própria devedora ${ }^{217}$.

A situação do gestor judicial, contudo, é diversa, pois tem ele por função específica administrar a empresa em dificuldade econômico-financeira, de modo que periodicamente e ao final de sua gestão deverá prestar contar, motivo pelo qual o pagamento de sua remuneração deve estar vinculado ao pontual cumprimento de suas obrigações e, em consequência, parte de sua remuneração deve ser reservada para pagamento após o encerramento do processo, reserva essa que, não havendo norma expressa, deve corresponder a $40 \%$ (quarenta por cento) do total de seus honorários.

\section{A responsabilidade dos credores pela eleição do gestor judicial}

O gestor judicial, como se viu, é eleito pelos credores em assembleia geral e nomeado pelo juiz, a quem compete examinar se a pessoa eleita não está impedida para o exercício do cargo (arts. 21 e 65 da LREF), ou seja, verifica não apenas a idoneidade do profissional, mas também (a) se nos últimos cinco anos, não exerceu cargo de administrador judicial, de gestor judicial, ou integrou comitê de credores, e não foi destituído, não

\footnotetext{
${ }^{217}$ Eis a ementa desse Agravo de Instrumento no 2009.002.41700: “Agravo de Instrumento. Recuperação Judicial. Administrador Judicial. Remuneração. O MM Juiz a quo fixou os honorários do administrador judicial em $1 \%$ (um por cento) dos débitos objeto da recuperação, a serem pagos em 24 (vinte e quatro) parcelas mensais. Posteriormente, o percentual em questão foi reduzido para $0,8 \%$, com o qual as empresas em recuperação não manifestaram qualquer oposição. Da mesma forma, quedou-se inerte o Ministério Público, em virtude do que a questão restou preclusa, inexistindo fundamento que justifiquem a modificação do referido percentual. No que concerne à reserva de $40 \%$ (quarenta por cento) da remuneração do administrador judicial, prevista no art. 24, parágrafo $2^{\circ}$, da Lei $n^{\circ} 11.101 / 2005$, trata-se de exigência destinada aos procedimentos de falência, nos quais o administrador funciona como gestor dos bens do falido. $\mathrm{Na}$ recuperação judicial, o principal papel do administrador judicial consiste na fiscalização das atividades do devedor e no cumprimento do plano de recuperação. Infere-se do art. 22, inciso II, alínea c, da Lei $n^{\circ}$ $11.101 / 2005$ que, na recuperação judicial, a prestação de contas do administrador judicial se refere às atividades da recuperanda e não de sua administração. Mantença da r. decisão agravada. Recurso conhecido e desprovido."
} 
prestou contas, ou as teve rejeitadas; e (b) se praticou qualquer dos atos que causam o afastamento do devedor ou seus administrador da gestão da empresa em recuperação judicial.

Pelo fato de ser escolhido em assembleia geral, a questão que surge é se os credores que elegeram o gestor judicial poderão vir a ser responsabilizados na hipótese de violação de deveres, descumprimento do plano ou convocação da recuperação judicial em falência.

Esta pergunta, como alerta SZTAJN (2007, p. 245) ao comentar os planos de recuperação judicial que contemplam a "concessão ao credores de direito de eleição em separado de administradores e de poder de veto em relação à matérias que o plano especificar" (LREF, art. 50, V),

parte da experiência com a nomeação de administradores pelo Banco Central do Brasil nos casos de intervenção extrajudicial em instituições financeiras em crise que deu margem a demandas de acionistas e controladores, mesmo frente à competência da instituição nesses casos.

Porque o gestor judicial, apesar de eleito pelos credores, é nomeado pelo juiz, a situação é diversa da que ocorre nos casos de liquidação extrajudicial de instituição financeira pelo Banco Central do Brasil (BACEN) ${ }^{218}$, onde o liquidante é escolhido e nomeado pelo BACEN, atribuindo-lhe a lei amplos poderes de administração e liquidação, "podendo nomear a demitir funcionários, fixando-lhes os vencimentos, outorgar e cassar mandatos, propor ações e representar a massa em Juízo ou fora dele" (art. 16).

Daí que, no processo de liquidação extrajudicial, “o liquidante atua em nome e por conta do Banco Central do Brasil, como verdadeiro longa manus dessa autarquia, administrando a empresa em liquidação sob as diretrizes ditadas pelo próprio BACEN", como já decidiu o STJ no Agravo Regimental no Recurso Especial nº 1.099.724-RJ, Relator Ministro Castro Meira ${ }^{219}$.

\footnotetext{
${ }^{218}$ A liquidação extrajudicial de instituição financeira é regulada pela Lei nº 6.024, de 13 de março de 1974.

${ }^{219}$ Esse acórdão do STJ contém longa explanação a respeito da nomeação e atuação do liquidante como mandatário do Banco Central do Brasil: "A liquidação foi processada por liquidante nomeado pelo Banco Central do Brasil, conforme preceitua o art. 16 da Lei 6.024/74, verbis: 'Art. 16. A liquidação extrajudicial será executada por liquidante nomeado pelo Banco Central do Brasil, com amplos poderes de administração e liquidação, especialmente os de verificação e classificação dos créditos, podendo nomear e demitir funcionários, fixando-lhes os vencimentos, outorgar e cassar mandatos, propor ações e representar a massa em Juízo
} 
O liquidante extrajudicial, assim, é escolhido pelo Banco Central do Brasil, e atua em nome e por conta do BACEN, como um seu mandatário, competindo-lhe liquidar os ativos para o pagamento dos passivos da instituição financeira em liquidação extrajudicial.

ou fora dele.' Segundo o dispositivo, a partir da nomeação do liquidante, a ele compete os poderes de administração e liquidação, inclusive, o de "outorgar e cassar mandatos, propor ações e representar a massa em Juízo ou fora dele". A partir das diretrizes legais, é fácil perceber que o liquidante atua em nome e por conta do Banco Central do Brasil, como verdadeira longa manus dessa autarquia, administrando a empresa em liquidação sob as diretrizes ditadas pelo próprio BACEN. Isso fica claro da leitura do $\S 1^{\circ}$ do art. 16 , que exige autorização expressa do BACEN para que o liquidante nomeado possa ultimar negócios pendentes, onerar ou alienar bens da entidade sujeita à liquidação. '§ $1^{\circ}$ Com prévia e expressa autorização do Banco Central do Brasil, poderá o liquidante, em benefício da massa, ultimar os negócios pendentes e, a qualquer tempo, onerar ou alienar seus bens, neste último caso através de licitações.' $\mathrm{O} \S 2^{\circ}$ do art. 16 também deixa clara a relação de dependência e subordinação entre o liquidante nomeado e o BACEN ao estatuir que a remuneração do primeiro será fixada por deliberação do segundo. '§ $2^{\circ}$ Os honorários do liquidante, a serem pagos por conta da liquidanda, serão fixados pelo Banco Central do Brasil.' Outros dispositivos da Lei 6.024/74 corroboram a idéia de que o liquidante é apenas representante ou mandatário do BACEN. Assim é que o art. 19 autoriza o BACEN a decretar o término da liquidação se julgar que os interessados apresentaram condições de garantia para o prosseguimento regular da empresa, verbis: 'Art . 19. A liquidação extrajudicial cessará: a) se os interessados, apresentando as necessárias condições de garantia, julgadas a critério do Banco Central do Brasil, tomarem a si o prosseguimento das atividades econômicas da empresa;' Nesse mesmo diapasão, o art. 21 condiciona o requerimento de falência da empresa em liquidação, formulado pelo liquidante, à prévia autorização do BACEN: 'Art . 21. A vista do relatório ou da proposta previstos no artigo 11, apresentados pelo liquidante na conformidade do artigo anterior o Banco Central do Brasil poderá autorizá-lo a: b) requerer a falência da entidade, quando o seu ativo não for suficiente para cobrir pelo menos a metade do valor dos créditos quirografários, ou quando houver fundados indícios de crimes falimentares.' Já o parágrafo único do art. 21 autoriza o BACEN, a qualquer tempo, a estudar "pedidos de cessação da liquidação extrajudicial, formulados pelos interessados, concedendo ou recusando a medida pleiteada, segundo as garantias oferecidas e as conveniências de ordem geral". Os arts. 24 e 30 determinam que os recursos contra as decisões do liquidante serão endereçados ao BACEN, verbis: 'Art. 24. Os credores serão notificados, por escrito, da decisão do liquidante, os quais, a contar da data do recebimento da notificação, terão o prazo de dez dias para recorrer, ao Banco Central do Brasil, do ato que lhes pareça desfavorável. Art. 30. Salvo expressa disposição em contrário desta Lei, das decisões do liquidante caberá recurso sem efeito suspensivo, dentro em dez dias da respectiva ciência, para o Banco Central do Brasil, em única instância.' As impugnações ao quadro geral de credores elaborado pelo liquidante também serão julgadas pelo Banco Central, nos termos do que dispõe o art. 26: 'Art. 26. A impugnação será apresentada por escrito, devidamente justificada com os documentas julgados convenientes, dentro em dez dias, contados da data da publicação de que trata o artigo anterior. $\S 3^{\circ} \mathrm{O}$ liquidante encaminhará as impugnações com o seu parecer, juntando os elementos probatórios, à decisão do Banco Central do Brasil.' Ademais, o art. 31 autoriza o liquidante, mediante prévia autorização do BACEN, a adotar qualquer forma de realização do ativo e liquidação do passivo: 'Art. 31. No resguardo da economia pública, da poupança privada e da segurança nacional, sempre que a atividade da entidade liquidanda colidir com os interesses daquelas áreas, poderá o liquidante, prévia e expressamente autorizado pelo Banco Central do Brasil, adotar qualquer forma especial ou qualificada de realização do ativo e liquidação do passivo, ceder o ativo a terceiros, organizar ou reorganizar sociedade para continuação geral ou parcial do negócio ou atividade da liquidanda.' Por fim, o art. 33 diz que o liquidante sempre prestará contas ao BACEN a qualquer tempo ou quando solicitado, verbis: 'Art. 33. O liquidante prestará contas ao Banco Central do Brasil, independentemente de qualquer exigência, no momento em que deixar suas funções, ou a qualquer tempo, quando solicitado, e responderá, civil e criminalmente, por seus atos.' Não há dúvida, portanto, de que o liquidante é mero mandatário do BACEN, agindo em nome e por conta dos interesses da autarquia." 
O gestor judicial, por seu turno, apesar de eleito pelos credores, é nomeado pelo juiz, de modo que é órgão auxiliar do Poder Judiciário que atua no processo de recuperação judicial na hipótese de afastamento do devedor, competindo-lhe administrar a empresa em dificuldade econômico-financeira.

Desse modo, tanto o procedimento de escolha como as funções exercidas pelo gestor judicial são diversos dos que regulam o liquidante extrajudicial de instituição financeira, razão pela qual ao primeiro não se aplicam as mesmas regras de responsabilidade que incidem sobre a atuação do Banco Central do Brasil.

Assim é que, como o liquidante atua em nome e por conta do BACEN, essa autarquia é que responde na hipótese de o liquidante, por ação ou omissão, causar danos à instituição financeira ou aos credores. No caso do gestor judicial, porém, por ser órgão auxiliar do Poder Judiciário, os credores não respondem no caso de danos causados pela violação de deveres, descumprimento do plano e até mesmo convolação da recuperação judicial em falência.

Os credores responderão perante o devedor, porém, se, dolosamente, não apenas elegerem para o exercício do cargo profissional que sabem impedido, mas também ocultarem do juízo as circunstâncias que justificam o impedimento à nomeação. Isto porque, nesta hipótese, aplica-se, por analogia, a regra do art. 117, § 1º letra “d”, da Lei 6.404/76 (Lei das Sociedades por Ações), segundo a qual “o acionista controlador responde pelos danos causados por atos praticados com abuso de poder. São modalidades de exercício abusivo de poder: [...] eleger administrador ou fiscal que sabe inapto, moral ou tecnicamente."

No caso específico do gestor, como a nomeação depende de exame pelo juiz, a responsabilização dos credores depende não apenas da ciência por eles da inidoneidade, como também da ocultação desses fatos do juízo. Em consequência, o descumprimento, pelo gestor judicial, de seus deveres, gerará a responsabilização pessoal do gestor, não dos credores que o elegeram, salvo a excepcional hipótese de dolo dos credores e omissão de informações ao juiz. 


\section{CAPÍTULO VI - CONSIDERAÇÕES FINAIS}




\section{CAPÍTULO VI - CONSIDERAÇÕES FINAIS}

A principal novidade introduzida no ordenamento jurídico brasileiro pela Lei $n^{\circ}$ 11.101, de 9.2.2005, foi a recuperação judicial, cuja finalidade, nos termos de ser art. 47, é viabilizar a superação da situação de crise econômico-financeira do devedor, de modo a permitir a manutenção da fonte produtora, do emprego dos trabalhadores e dos interesses dos credores, mediante a preservação da empresa.

E buscando a preservação da empresa, o art. 64 da LREF, seguindo a tradição do direito positivo brasileiro, dispõe que os administradores eleitos na forma do contrato (ou do estatuto) social são mantidos em seus cargos, pois a experiência norte-americana comprovou que o imediato afastamento dos administradores da sociedade em recuperação judicial traz mais prejuízos do que benefícios, porquanto os gestores que serão afastados procrastinam ao máximo o requerimento da recuperação, exatamente para não serem alijados de suas funções.

Mas se, de um lado, a lei falimentar mantém o devedor e seus administradores na condução da empresa recuperanda, de outro, impõe limites à liberdade de gestão, porquanto restringem a prática de alguns atos (tais como o disposto no art. 66 da LREF), e suas condutas passam a ser fiscalizadas pelo comitê de credores (se instalado) e pelo administrador judicial.

Ademais, os incisos do art. 64 da LREF contemplam hipóteses de circunstâncias que, se verificadas, acarretam o afastamento dos administradores e/ou do próprio devedor, sendo que, no primeiro caso, os administradores serão substituídos por novos eleitos na forma prevista no contrato (ou estatuto) social, enquanto no segundo caso (afastamento do devedor) os credores reunir-se-ão em assembleia e elegerão o gestor judicial que será nomeado pelo juiz.

A LREF, porém, foi muito discreta ao regular a nomeação e a atuação do gestor judicial, o que gerou discussões doutrinárias e jurisprudenciais a respeito da correta interpretação do termo "devedor" empregado nos arts. 64 e 65 da LREF, das hipóteses e do procedimento para o afastamento do devedor e, fundamentalmente, das funções 
desempenhadas pelo gestor judicial para a superação da crise econômico-financeira do devedor que se vale da recuperação judicial.

A partir da interpretação desses dispositivos legais, do exame das posições doutrinárias e da análise de decisões jurisprudenciais, concluiu-se que o afastamento dos administradores e/ou do devedor é medida excepcional, pois as hipóteses descritas nos incisos do art. 64 da LREF são numerus clausus e não admitem interpretação extensiva. Ademais, porque se trata de restrição a direitos, o afastamento só pode ocorrer após o devido processo legal, em que se assegure aos administradores e ao devedor a ampla defesa e o contraditório.

Demonstrou-se, por outro lado, que há divergências quanto à interpretação do termo "devedor" para efeito de afastamento de substituição pelo gestor judicial eleito pelos credores em deliberação assemblear e nomeado pelo juiz. Isto porque, para alguns autores, o termo "devedor" refere-se ao empresário individual (pessoa natural) e ao administrador se o requerente da recuperação for uma sociedade limitada empresária ou uma sociedade por ações. Para outros, porém, o termo "devedor" deve ser lido como os sócios, controladores ou não, da sociedade limitada empresária ou da sociedade por ações em crise econômico-financeira.

Examinando-se essas posições doutrinárias, concluiu-se que a melhor interpretação do termo "devedor", para efeito de incidência dos arts. 64 e 65 da LREF, é a própria sociedade empresária devedora (limitada ou por ações), de modo que, se se verificar a ocorrência de uma das circunstâncias descritas nos incisos do já referido art. 64, afastada será a própria sociedade empresária devedora, na qual hipótese os credores elegerão profissional idôneo (ou pessoa jurídica especializada), que deverá ser nomeada pelo juiz para o exercício da função de gestor judicial.

A consequência do afastamento da própria sociedade empresária devedora é que o gestor judicial, cuja função é gerir a atividade da empresa em dificuldade econômico-financeira, não ingressa no quadro social (ou seja, sem substituir seus diretores, conselheiros ou acionistas): ele exerce suas funções de fora da sociedade, sem integrar o contrato plurilateral, nem eventuais pactos parassociais, tais como acordo de quotistas ou de acionistas. 
Da mesma forma, também se expôs que não há consenso entre os doutrinadores em relação às funções do gestor judicial, pois enquanto alguns autores sustentam que ao gestor judicial compete apenas orientar os administradores, livremente escolhidos na forma do contrato (ou estatuto) social, quanto ao cumprimento do plano aprovado; para outros estudiosos, contudo, o gestor judicial efetivamente pratica atos de gestão da pessoa jurídica devedora. Confrontando-se essas posições e interpretando-se a legislação, concluiu-se que ao gestor judicial compete efetivamente administrar a empresa (não a pessoa jurídica afastada) devedora, assumindo a gestão de todo o patrimônio da sociedade empresária devedora, podendo praticar todos os atos necessários à preservação da atividade produtiva.

Isso não obstante, o gestor judicial também não assume a condução do processo de recuperação judicial, a qual permanece sob a responsabilidade exclusiva da sociedade empresária devedora, devidamente presentada por seus órgãos de administração constituídos na forma ajustada pelos sócios/acionistas em seu contrato/estatuto social.

Em outras palavras, o gestor assume a administração das atividades e de todo o patrimônio da sociedade empresária devedora, o que não afasta o devedor de, atuando na forma estabelecida em seus atos societários, comparecer no processo de recuperação judicial para formular requerimentos ao juiz, apresentar plano de recuperação judicial, discutir eventuais alterações no plano. Somente ao devedor, não ao gestor, compete praticar atos que digam respeito exclusivamente ao próprio processo judicial de recuperação, em especial a aceitação ou não das alterações ao plano de recuperação judicial apresentadas pelos credores.

Na condução da atividade empresarial são impostos alguns limites à atuação do gestor judicial, tal como a norma do art. 66 da LREF, que dirigida ao devedor em recuperação judicial, também se aplica ao gestor, de modo que não pode ele, alienar ou gravar bens sem autorização judicial, após a manifestação não apenas do comitê de credores, mas também do próprio devedor afastado da gestão da empresa, mas não desapropriado de seus bens e direitos. 
Quer a sociedade seja administrada por gestor judicial, quer esta função seja acometida aos administradores escolhidos pelos sócios na forma estabelecida no plano de recuperação ou no contrato (ou estatuto) social, aos gestores da empresa se impõem os mesmos deveres exigidos para o administrador de qualquer sociedade, ou seja, os deveres de diligência (consubstanciado na prática de todos os atos segundo preconiza as modernas técnicas de administração de empresa), de lealdade (para com a requerente da recuperação judicial, e não para com os credores que eventualmente tenham indicado o administrador ou eleito o gestor judicial) e de obediência à lei. Porque o gestor judicial não integra o contrato plurilateral, dele não se exige o respeito ao contrato (ou estatuto) social, com exceção da cláusula que fixa o objeto social.

Na hipótese de violação de qualquer um desses deveres, o gestor judicial responderá pessoalmente pelas obrigações assumidas. Caso contrário, se os deveres forem cumpridos, o gestor não responderá pelos atos praticados na gestão da atividade empresarial, ainda que a recuperação judicial venha a ser convolada em falência.

Como se viu, porém, há muitas divergências quanto às hipóteses de nomeação do gestor judicial, bem como quanto às suas funções, divergências essas que decorrem, fundamentalmente, do fato de a LREF ter sido muito discreta na regulamentação da administração da sociedade empresária em recuperação judicial, tendo se limitado a dispor que o devedor e seus administradores são mantidos na condução da atividade empresarial, mas na hipótese de ocorrência das circunstâncias descritas nos incisos do art. 64, o administrador e/ou o devedor serão afastados e substituídos, respectivamente, por novos administradores eleitos na forma prescrita no contrato (ou estatuto) social ou pelo gestor judicial eleito pelos credores e nomeado pelo juiz, aplicando a este último algumas das normas que regulam o administrador judicial.

Se, como expressamente dispõe o art. 47 da LREF, a recuperação judicial tem por escopo a preservação da empresa, a legislação deveria ter regulado, de modo mais minucioso, a condução da atividade empresarial, pois a insegurança jurídica, além de acarretar aumento nos custos de transação, é causa de resistência a que o devedor em dificuldade venha a requerer sua recuperação judicial que, em consequência, procrastina a apresentação do pedido, o que pode causar (e no mais das vezes causa) deterioração da situação econômica e agravamento da crise. 
Impõe-se, assim, a revisão, ainda que pontual, da LREF para se regular a administração do devedor em recuperação judicial, estabelecendo especificamente quem é o devedor que poderá vir a ser afastado e substituído pelo gestor judicial, definindo-se também o procedimento para o afastamento (de modo a assegurar-se ao devedor a ampla defesa e o contraditório), e as funções que serão exercidas por esse órgão da recuperação judicial. 


\section{REFERÊNCIAS}

ABRÃO, Carlos Henrique. Os créditos bancários e a recuperação da empresa. Revista de Direito Bancário e do Mercado de Capitais, n. 3, p. 78. 1998

. Empresa individual: EIRELI: lei $\mathrm{n}^{\circ}$ 12.441/2011 e Instrução Normativa nº 117/2011. São Paulo: Atlas, 2012.

ABRÃO, Nelson. A continuação do negócio na falência. São Paulo: Leud, 1975

Curso de Direito Falimentar. 5 ed. São Paulo: Leud, 1997.

O síndico na falência: contendo Projeto Lei 4.376/93 e sua emenda.

Atualização de Carlos Henrique Abrão. 2. ed. São Paulo: Universitária de Direito, 1999.

ALMEIDA, Amador Paes de. Curso de falência e recuperação de empresa. São Paulo: Saraiva, 2005.

ARGERI, Saúl A. La Quebra Y Demas Procesos Concursales. La Plata: Editora Platense, 1972

ASQUINI, Alberto. Os perfis da empresa. Trad. Fabio Konder Comparato. Revista de Direito Mercantil, Industrial, Econômico e Financeiro, n. 104, 1996, p. 109.

AYOUB, Luiz Roberto; CAVALLI, Cássio. A construção jurisprudencial da recuperação judicial de empresas. Rio de Janeiro: Forense, 2013

BAIRD, Douglas G.; JACKSON, Thomas H.; e ADLER, Barry E. Bankruptcy, cases, problems and materials. 3 ed. Nova Iorque: Foundation Press, 2000.

BALBINO, Márcia de Paoli. In: CORRÊA-LIMA, Osmar Brina; CORRÊA-LIMA, Sérgio Mourão (Coord.). Comentários à Nova Lei de Falência e Recuperação de Empresas: Lei n ${ }^{\circ}$ 11.101, de 09 de fevereiro de 2005. Rio de Janeiro: Forense, 2009.

BARAVAllE, Roberto A.; GRANADOS, Ernesto I. J., Ley de Concursos Y Quiebras 24.522. Rosario: Liber, 1995

BARRETO FILHO, Oscar. "Síntese da evolução histórica do Direito Comercial brasileiro”. Revista de Direito Mercantil, Industrial, Econômico e Financeiro, n. 24, p. 23.

BERGER, Dora. A insolvência no Brasil e na Alemanha. Estudo comparado entre a Lei de Insolvência Alemã de 01.01.1999 (traduzida) e o Projeto de Lei brasileiro no 4.376 de 1993 (com as alterações de 1999) que regula a falência, a concordata preventiva e a recuperação de empresas. Porto Alegre: Sérgio Antonio Fabris Editor, 2001

BERTASI, Maria Odete Duque. Administrador judicial, comitê e assembléia de credores na lei de recuperação de empresas e falência. In: MACHADO, Rubens Approbato 
(Coord.). Comentários à nova lei de falências e recuperação de empresas: doutrina e prática: lei 11.101 de 9/2/2005 e LC 118 de 9/2/2005. 2. ed. São Paulo: Quartier Latin, 2007. p. 129-163

BEVILAQUA, Clóvis. Código Civil dos Estados Unidos do Brasil. São Paulo: Livraria Francisco Alves, 1927

BEZERRA FILHO, Manoel Justino. Lei de Falências comentada. São Paulo: RT, 2001. São Paulo: RT, 2006.

Jurisprudência da nova lei de recuperação de empresas e falências. Lei de recuperação de empresas e falências comentada. São Paulo: RT, 2007.

BIOLCHI, Osvaldo. Apresentação. In: TOLEDO, Paulo F. C. Salles de; ABRÃO, Carlos Henrique (Coord.). Comentários à lei de recuperação de empresas e falência. 2. ed. São Paulo: Saraiva, 2007. p. XXXV-XLV

BOLTON, Patrick. Towards a statutory approach to sovereign debt restructuring - Lessons from corporate bankruptcy practice around the world. International Monetary Fund Staff Papers, v. 50, Washington, 2003.

BORBA, José Edwaldo Tavares. Direito societário. Rio de Janeiro: Renovar, 2007.

BRANCO, Adriano Castello. O conselho de administração nas sociedades anônimas. Rio de Janeiro: Forense Universitária, 2007.

CAMPINHO, Sérgio. Falência e recuperação de empresa: o novo regime da insolvência empresarial. Rio de Janeiro: Renovar, 2008.

CARVALHO, Lucila de Oliveira. A responsabilidade do administrador da sociedade limitada. Rio de Janeiro: Forense, 2006.

CARVAlhosa, Modesto. Comentários ao código civil: parte especial: do direito de empresa. Coordenação Antônio Junqueira de Azevedo. São Paulo: Saraiva, 2003. v. 13.

CASTRO, Rodrigo R. Monteiro de. A administração das sociedades anônimas em recuperação judicial. In: CASTRO, Rodrigo R. Monteiro de; ARAGÃO, Leandro Santos de (Coord.). Direito societário e a nova lei de falências e recuperação de empresas. São Paulo: Quartier Latin, 2006.

CEREZETTI, Sheila Christina Neder. A recuperação judicial de sociedade por ações. O princípio da preservação da empresa na lei de recuperação e falência. São Paulo: Malheiros, 2012.

COELHO, Fábio Ulhoa. Comentários à nova lei de falências e de recuperação de empresas. 5. ed. São Paulo: Saraiva, 2008. 
2007. vol. 2

Curso de direito comercial: direito de empresa. São Paulo: Saraiva, . A sociedade limitada no novo código civil. São Paulo: Saraiva, 2003.

COMPARATO, Fábio Konder. Ensaios e pareceres de direito comercial. Rio de Janeiro: Forense, 1978.

COSTA, Luiz Antonio Silva. A lei de recuperação de empresas. São Paulo: Lex Editora, 2005.

COROTTO, Susana. Modelos de reorganização empresarial brasileiro e alemão. Comparação entre a Lei de Recuperação e Falências de Empresas (LRFE) e a Insolvenzordnung (InsO) sob a ótica da viabilidade prática. Porto Alegre: Sergio Antonio Fabris Editor, 2009

CORRÊA-LIMA, Osmar Brina. Sociedade anônima. Belo Horizonte: Del Rey, 2005.

; CORRÊA-LIMA, Sérgio Mourão (Coord.). Comentários à nova lei de falência e recuperação de empresas: lei $n^{0}$. 11.101, de 09 de fevereiro de 2005 . Rio de Janeiro: Forense, 2009.

DONAGGIO, Angela Rita Franco. Governança Corporativa e Novo Mercado: Proteção ao investidor e falhas no marco regulatório. São Paulo: Saraiva, 2012.

EIZIRIK, Nelson. Temas de direito societário. Rio de Janeiro: Renovar, 2005.

EPSTEIN, David G.; NICKLES, Steve H.; WHITE, James J. Bankruptcy. St Paul: West Publishing CO, 1993

FASSI, Santiago C.; GEBAHRDT, Marcelo. Concursos. Buenos Aires: Ediatorial Astrea, 1993

FERREIRA, Waldemar. Tratado de Direito Comercial. São Paulo: Saraiva, v. 14, 1965

. Tratado de Direito Comercial. São Paulo: Saraiva, v. 15, 1966

FONSECA, Humberto Lucena Pereira da. In: CORRÊA-LIMA, Osmar Brina; CORRÊALIMA, Sérgio Mourão (Coord.). Comentários à Nova Lei de Falência e Recuperação de Empresas: Lei n ${ }^{\circ}$ 11.101, de 09 de fevereiro de 2005. Rio de Janeiro: Forense, 2009.

FRANÇA, Erasmo Valladão A. e N. Da assembleia-geral de credores: arts. 35-46. In: SOUZA JÚNIOR, Francisco Satiro de; PITOMBO, Antônio Sérgio A. de Moraes (Coord.). Comentários à lei de recuperação de empresas e falência: lei 11.101/2005. 2. ed. São Paulo: Revista dos Tribunais, 2007.

FRANCO, Vera Helena de Mello; SZTAJN, Rachel. Falência e recuperação da empresa em crise: comparação com as posições do direito europeu. Rio de Janeiro: Campus Jurídico, 2008. 
FRONTINI, Paulo Salvador. "O caso da falência da Sanderson e as tendências atuais do direito falimentar". Revista de Direito Mercantil, Industrial, Econômico e Financeiro, n. 15-16, p. 243. 1974.

. "Do Estado de Falido: sua configuração - Inovações da nova lei de recuperação e falência". Revista de Direito Mercantil, Industrial, Econômico e Financeiro, n. 138, p. 7. 2005.

GUERREIRO, José Alexandre Tavares. Responsabilidade dos administradores de sociedades anônimas. Revista de Direito Mercantil Industrial, Econômico e Financeiro, São Paulo, n. 42, p. 69. 1981.

GUIMARÃES, Maria Celeste Morais. Recuperação judicial de empresas e falência à luz da lei n. 11.101/2005. Belo Horizonte: Del Rey, 2007.

JORIO, Alberto. Le crisi d'impresa e il fallimento, Milão: Giuffrè, 2000.

KUGELMAS. Alfredo Luiz; PINTO, Gustavo Henrique Sauer de Arruda. In: LUCCA, Newton de. DOMINGUES, Alessandra de Azevedo (Coord.). Direito Recuperacional. Aspectos teóricos e práticos. São Paulo: Quartier Latin, 2009.

LAMY F., Alfredo; PEDREIRA, José Luiz Bulhões. A Lei das S.A. Rio de Janeiro: Renovar, $3^{\text {a }}$ ed., $1^{\circ}$ vol. 1997

LAZZARESCHI NETO, Alfredo Sérgio, Lei das sociedades por ações anotada. $3^{\mathrm{a}}$ ed. São Paulo: Saraiva, 2010.

LOBO, Jorge. Da assembleia-geral de credores: arts. 35-69. In: TOLEDO, Paulo F. C. Salles de; ABRÃO, Carlos Henrique (Coord.). Comentários à lei de recuperação de empresa e falência. 2. ed. São Paulo: Saraiva, 2007.

LUCCA, Newton de; SIMÃO FILHO, Adalberto (Coord.). Comentários à nova lei de recuperação de empresas e de falências. São Paulo: Quartier Latin, 2005.

; DOMINGUES, Alessandra de Azevedo (Coord.). Direito Recuperacional. Aspectos teóricos e práticos. São Paulo: Quartier Latin, 2009.

LUCENA, José Waldecy. Das sociedades limitadas. Rio de Janeiro: Renovar, 2005.

MACHADO, Rubens Approbato (Coord.). Comentários à nova lei de falências e recuperação de empresas: doutrina e prática. São Paulo: Quartier Latin, 2007.

MANDEL, Julio Kahan. A Nova Lei de Falências e de Recuperações de Empresas Anotada. São Paulo: Saraiva, 2005.

MARTINS, Pedro Batista. Responsabilidade de acionista controlador. Considerações doutrinária e jurisprudencial. Revista de Direito Bancário e do Mercado de Capitais, São Paulo, v. 27, p. 50. 
MARZAGÃO, Lídia Valério. A recuperação judicial. In: MACHADO, Rubens Approbato (Coord.). Comentários à nova lei de falências e recuperação de empresas: doutrina e prática. São Paulo: Quartier Latin, 2007.

MENDONÇA, José Xavier Carvalho de. Tratado de direito comercial brasileiro. Rio de Janeiro: Freitas Bastos, 1914, v. 3.

1916, v. 7. . Tratado de direito comercial brasileiro. Rio de Janeiro: Freitas Bastos, . Tratado de direito comercial brasileiro. Rio de Janeiro: Freitas Bastos, 1917, v. 8.

MENEZES, Maurício Moreira Mendonça de. O poder de controle nas companhias em recuperação judicial. Rio de Janeiro: Forense, 2012.

MILANI, Mário Sérgio. Lei de recuperação judicial, recuperação extrajudicial e falência comentada. São Paulo: Malheiros, 2011.

MORI, Celso Cintra. Apresentação. In: PAIVA, Luiz Fernando Valente de (Coord.). Direito falimentar e a nova lei de falências e recuperação de empresas. São Paulo: Quartier Latin, 2005.

MUNHOZ, Eduardo Secchi. In: SOUZA JÚNIOR, Francisco Satiro de; PITOMBO, Antônio Sérgio $\mathrm{A}$. de Moraes (Coord.). Comentários à lei de recuperação de empresas e falência: lei 11.101/2005. São Paulo: Revista dos Tribunais, 2007.

Desafios do direito societário brasileiro na disciplina da companhia aberta: avaliação dos sistemas de controle diluído e concentrado. In: CASTRO, Rodrigo R. Monteiro de; ARAGÃO, Leandro de. (Coord.). Direito societário: desafios atuais. São Paulo: Quartier Latin, 2009.

NEGRÃO, Ricardo. Aspectos objetivos da lei de recuperação de empresas e de falências. São Paulo: Saraiva, 2008.

lo: Saraiva, 2010.

A eficiência do processo judicial na recuperação de empresa. São Pau-

PACHECO, José da Silva. Processo de recuperação judicial, extrajudicial e falência: em conformidade com a Lei $n^{0}$ 11.101/05, alteração da Lei $n^{0} 11.127 / 05$. Rio de Janeiro: Forense, 2007.

PAIVA, Luiz Fernando Valente de (Coord.). Direito falimentar e a nova lei de falências e recuperação de empresas. São Paulo: Quartier Latin, 2005.

PARENTE, Flávia. O dever de diligência dos administradores de sociedades anônimas. Rio de Janeiro: Renovar, 2005. 
PENTEADO, Mauro Rodrigues. In: SOUZA JÚNIOR, Francisco Satiro de; PITOMBO, Antônio Sérgio A. de Moraes (Coord.). Comentários à lei de recuperação de empresas e falência: lei 11.101/2005. São Paulo: Revista dos Tribunais, 2007.

In: CORRÊA-LIMA, Osmar Brina; CORRÊA-LIMA, Sérgio Mourão (Coord.). Comentários à nova lei de falência e recuperação de empresas: lei $\mathbf{n}^{\mathbf{0}}$. 11.101, de 09 de fevereiro de 2005. Rio de Janeiro: Forense, 2009.

PERIN JUNIOR, Ecio. Preservação da Empresa na Lei de Falências. Saraiva, 2009.

O administrador judicial e o comitê de credores no novo direito concursal brasileiro. In: PAIVA, Luiz Fernando Valente de (Coord.). Direito falimentar e a nova lei de falências e recuperação de empresas. São Paulo: Quartier Latin, 2005.

PIMENTA, Eduardo Goulart. Recuperação de empresas: um estudo sistematizado da Nova Lei de Falências. São Paulo, 2006. 290 p.

. Atribuições e perfil do Administrador Judicial, Gestor Judicial e Comitê de Credores no contexto da Lei ${ }^{\circ}$ 11.101/05. In: CASTRO, Moema A. S. de., CARVALHO, William Eustáquio de. (Coord.). Direito falimentar contemporâneo. Porto Alegre: Sérgio Antonio Fabris, 2008. p. 9-29

PONTES DE MIRANDA, F. C. de. Tratado de direito privado. $4^{\text {a }}$ ed. Rio de Janeiro: Editor Borsoi, 1974. t. 3

30

Tratado de direito privado. $3^{\mathrm{a}}$ ed. Rio de Janeiro: Editor Borsoi, 1971. t. . Tratado de direito privado. $3^{\text {a }}$ ed. Rio de Janeiro: Editor Borsoi, 1972. t.

49

. Tratado de direito privado. $3^{\mathrm{a}}$ ed. Rio de Janeiro: Editor Borsoi, 1972. t.

50

PUGLIESE, Adriana Valéria. Direito Falimentar e Preservação da Empresa. São Paulo; Quartier Latin, 2013

REQUIÃO, Rubens. Curso de Direito Falimentar. $1^{\text {a }}$ ed. São Paulo: Saraiva, 1975, v. 1 Curso de Direito Comercial. 17. ed. São Paulo: Saraiva, 1988. v. 2, 493

p.

RESTIFFE, Paulo Sérgio. Recuperação de empresas: de acordo com a lei n. 11.101, de 09.02.2005. Barueri: Manole, 2008.

RETTO, Marcel Gomes Bragança. Sociedades limitadas. Barueri: Manole, 2007.

RIVERA, Julio Cesar. "El derecho concursal: uma rama cuya legislación está em permanente cambio". Revista de Derecho Comparado, Rubinzal Culzoni, nº 15, p. 11-52, 2009. Disponível em http://www.rivera.com.ar/publications.pdf 
ROUILLON, Adolfo A. N. Régimen de Concursos Y Quiebras. Buenos Aires: Ediatorial Astrea, 2012

ROQUE, Sebastião José. Direito de Recuperação de empresas. São Paulo: Ícone, 2005,

SALOMÃO FILHO, Calixto. Recuperação de empresas e interesse social. In: SOUZA JUNIOR, Francisco Satiro; PITOMBO, Antônio Sérgio de Moraes (Coord.). Comentários à lei de recuperação de empresas e falência: lei 11.101/2005. 2. ed. São Paulo: Revista dos Tribunais, 2007.

SANTOS, Paulo Penalva (Coord.). A Nova Lei de Falências e de Recuperações de Empresas. Rio de Janeiro: Forense, 2006.

SILVA, Alexandre Couto. Responsabilidade dos administradores de S/A. Rio de Janeiro: Campus Jurídico, 2007. 251 p.

SIMIONATO, Frederico Augusto Monte. Tratado de direito falimentar. Rio de Janeiro: Forense, 2008.

SKELL, David A. Jr. Debt's dominion: a history of bankruptcy law in America. $2^{\text {nd }}$ ed. Princeton: Princeton University Press, 2004.

SOUZA JUNIOR, Francisco Satiro; PITOMBO, Antônio Sérgio de Moraes (Coord.). Comentários à lei de recuperação de empresas e falência: lei 11.101/2005. São Paulo: Revista dos Tribunais, 2007.

STANGHELLINI, Lorenzo. Le crisi di impresa fra diritto ed economia: le procedura di insolvenza. Bologna: Il Mulino, 2007

SZTAJN, Rachel. In: SOUZA JÚNIOR, Francisco Satiro de; PITOMBO, Antônio Sérgio A. de Moraes (Coord.). Comentários à lei de recuperação de empresas e falência: lei 11.101/2005. São Paulo: Revista dos Tribunais, 2007.

TAJRA, Alexandre; GIANSANTE, David. C.. In: LUCCA, Newton de. DOMINGUES, Alessandra de Azevedo (Coord.). Direito Recuperacional. Aspectos teóricos e práticos. São Paulo: Quartier Latin, 2009.

TEBET, Ramez. Relatório. In: MACHADO, Rubens Approbato (Coord.). Comentários à nova lei de falências e recuperação de empresas: doutrina e prática: lei 11.101 de 9/2/2005 e LC 118 de 9/2/2005. 2. ed. São Paulo: Quartier Latin, 2007

TEIXEIRA DE FREITAS, Augusto. Esboço do código civil. Rio de Janeiro: [s.n.], 1860, v. 7.

TOLEDO, Paulo Fernando Campos Salles de. ABRÃO, Carlos Henrique (Coord.). Comentários à lei de recuperação de empresas e falência. São Paulo: Saraiva, 2007.

TOMAZETTE, Marlon. Curso de direito empresarial: falência e recuperação de empresas. 1. ed. São Paulo: Atlas, v. 3. 2011 
VALVERDE, Trajano de Miranda. Comentários à lei de falências: decreto-lei n. 7.661, de 21 de junho de 1945. Atualização de J. A. Penalva Santos e Paulo Penalva Santos. Rio de Janeiro: Forense, 1999.

VASCONCELOS, Ronaldo. Direito processual falimentar. São Paulo: Quartier Latin, 2008.

VERÇOSA, Haroldo Malheiros Duclerc. O status jurídico do controlador e dos administradores na recuperação judicial. Revista de Direito Mercantil Industrial, Econômico e Financeiro, São Paulo, 2006ª ,v. 143, p. 21

. Curso de direito comercial: teoria geral das sociedades: as sociedades em espécie do Código Civil. São Paulo: Malheiros, 2006 ${ }^{\mathrm{b}}$. v. 2.

. In: SOUZA JÚNIOR, Francisco Satiro de; PITOMBO, Antônio Sérgio A. de Moraes (Coord.). Comentários à lei de recuperação de empresas e falência: lei 11.101/2005. 2. ed. São Paulo: Revista dos Tribunais, 2007. p. 163-185 